University of Rhode Island

DigitalCommons@URI

Open Access Dissertations

2003

\title{
Micropropagation of Carnivorous Plants
}

Kenneth Stephen Uhnak

University of Rhode Island

Follow this and additional works at: https://digitalcommons.uri.edu/oa_diss

\section{Recommended Citation}

Uhnak, Kenneth Stephen, "Micropropagation of Carnivorous Plants" (2003). Open Access Dissertations.

Paper 471.

https://digitalcommons.uri.edu/oa_diss/471

This Dissertation is brought to you for free and open access by DigitalCommons@URI. It has been accepted for inclusion in Open Access Dissertations by an authorized administrator of DigitalCommons@URI. For more information, please contact digitalcommons-group@uri.edu. 
MICROPROPAGATION OF CARNIVOROUS PLANTS

BY

KENNETH STEPHEN UHNAK

A DISSERTATION IN PARTIAL FULFILLMENT OF THE

REQUIREMENT FOR THE DEGREE OF

DOCTOR OF PHILOSOPHY

IN

BIOLOGICAL SCIENCES

UNIVERSITY OF RHODE ISLAND

2003 
DOCTOR OF PHILOSOPHY DISSERTATION

OF

KENNETH S. UHNAK

APPROVED:

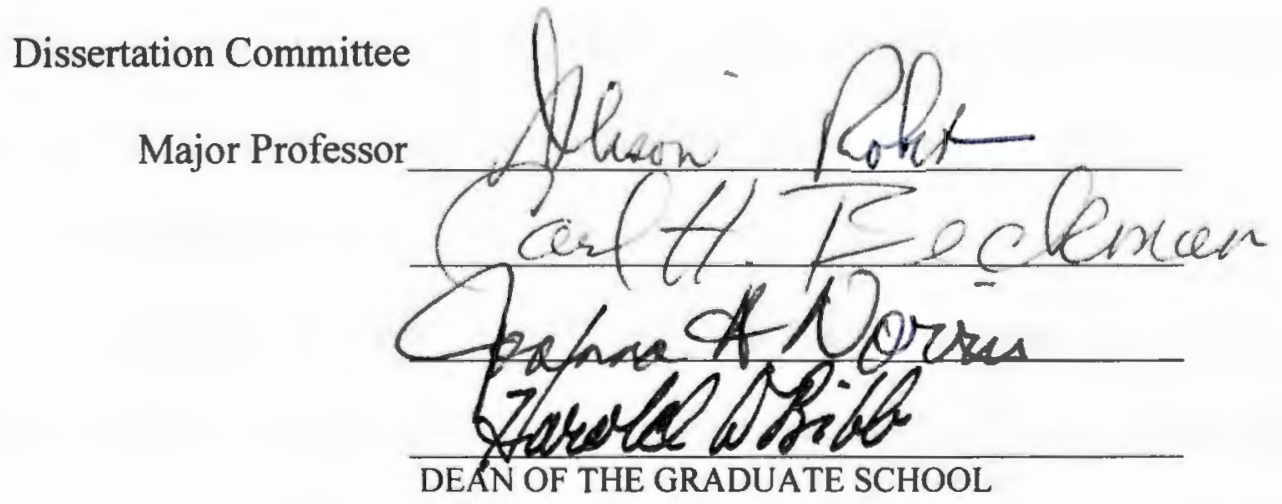

UNIVERSITY OF RHODE ISLAND

2003 


\begin{abstract}
A simple, efficient system for seed surface disinfestation and in vitro germination was developed for the carnivorous pitcher plants Darlingtonia californica and Sarracenia leucophylla. Of the disinfectants tested, hydrogen peroxide or $10 \%$ Clorox ${ }^{\circledR}$ were most effective for disinfesting seeds of $D$. californica, while concentrated sulfuric acid worked best for S. leucophylla. Differences in the effectiveness of sterilants were associated by differences in seed coat morphology. Seeds of $D$. californica imbibed at $4-7^{\circ} \mathrm{C}$ in sterile deionized water with surfactant and gibberellin germinated earlier than seeds without exposure to gibberellin. Unimbibed seeds of S. leucophylla germinated rapidly in sterile water after treatment in concentrated sulfuric acid.
\end{abstract}

Scanning electron microscopy of $D$. californica seed coats revealed waxy trichomes covering the seed surface. In contrast, the seed coats of S. leucophylla were pitted with surface and sub-surface cells possessing heavily thickened cell walls. These cells were devoid of contents. Fungal hyphae were observed on the seed surface and within empty cells of the integuments. Scanning electron microscopy observations and comparison of seed coat morphology of the carnivorous plant genera Drosera, Dionaea, Sarracenia and Darlingtonia revealed a wide range of differences in structure and ornamentation, which may suggest a species specific approach to surface disinfestation.

A simple effective system for the in vitro growth, multiplication and rooting of axenically germinated seedlings of $D$. californica was developed. Seedlings grown on solid $1 / 2$ strength Murashige and Skoog medium produced more biomass and more and 
longer pitcher leaves than seedlings grown on other solid media assayed. Root development on solid media was minimal and usually limited to the seminal root regardless of the medium. Seeds stimulated by gibberellic acid prior to germination and exposed to auxin and cytokinin during early seedling development produced multiple offshoots as well as fibrous root systems when transferred to $1 / 2$ strength liquid medium containing charcoal. Similarly treated seedlings transferred to $1 / 2$ strength liquid media without charcoal produced multiple offshoots but fewer root systems. Seedlings cultured in medium without charcoal produced more but smaller pitchers than seedlings cultured in medium containing charcoal. Multiplication did not occur on solid media, and seedling growth was stunted. Seedling multiplication through offshoots occurred in all liquid media and was both prolific and rapid. Darlingtonia californica was regenerated from whole, in vitro germinated seedlings and excised segments from in vitro generated juvenile pitchers. When incubated on solid Phytomax Orchid Multiplication Medium, seedlings produced protocorm-like bodies and green leafy callus When divided and subcultured in liquid Phytomax Orchid Multiplication Medium, explants of both protocorm-like bodies and green, leafy callus gave rise to multiple shoots as well as more protocorm-like bodies and green, leafy callus. These could be further divided and subcultured. Transverse segments of excised pitcher leaves from axenically-grown seedlings produced shoots and protocorm-like bodies when subcultured in liquid Phytomax Orchid Multiplication Medium. Unlike D. californica, seedlings of $S$. leucophylla did not readily produce offshoots when incubated on solid media. A protocol for extraction of embryos from selected Sarracenia species was developed. 


\section{ACKNOWLEDGEMENTS}

I especially thank my major professor Dr. Alison Roberts for her guidance, patience and vision in helping me bring this project to fruition. I thank her for believing in me, and for keeping me focused during difficult times (of which there were many). This must not have been easy for her.

I thank the members of my committee, Dr. Richard Koske for his guidance and advice throughout the years, Dr. Joanna Norris for her exceptional patience, and Dr. Carl Beckman whose spirituality has left its mark on me. I also thank Dr. Larry Englander for acting as chair of my defense.

I thank Chris Nerone, Veronica Masson, Marybeth Able, Stacie Paquette, Jane Leary, my sons Kenneth and Nicklaus Uhnak, John Phillip Jr., and Judy Gould. I thank Ranger Hall graduate students Ryan Tainsh and Mike Budziszek for helping with statistics and computer problems, Alissa Neill for support, and Mary Beth Hanley for kindly leaving food in the refrigerator on nights I worked until dawn. I thank Dr. Eric Roberts for generously saving me from certain destruction during the final hours.

I thank the Alley family for believing in me enough to offer their prayers of support. I thank William Alley, Janice Alley, and William Alley Jr. I also thank Claudia, Becky, Ron and Nana Franke for their much appreciated support and prayers. I thank my parents Dominic and Bernadette for their love and support.

A special thank-you is due to my wife, Leslie Anne Uhnak, who not only typed much of this dissertation (more than once), but also endured a somewhat chaotic life during its completion. I also thank her and my stepdaughter, Kelsey Desrosiers, for their support and belief in me during this remarkable ordeal. 


\section{PREFACE}

This dissertation was written in the manuscript style format as approved by the Graduate School of the University of Rhode Island with modifications as required for submission to the journal. Plant Cell Tissue and Organ Culture. Three manuscripts are included.

Manuscript I:

ESTABLISHMENT OF A MiCROPROPAGATION SYSTEM FOR MEMBERS OF THE Carnivorous Plant Family Sarraceniaceae. I. Surface Sterilization and IN VITRO GeRmination of SEEDS of DARLINGTONIA CALIFORNICA WITH NOTES AND OBSERVATIONS ON SARRACENIA LEUCOPHYLLA, S. ALATA, AND S. PURPUREA

Manuscript II:

ESTABLISHMENT OF A MICROPROPAGATION SYSTEM FOR MEMBERS OF THE Carnivorous Plant Family Sarraceniaceae. II. IN Vitro Growth and Early Seedling Development of the North American Pitcher Plant Darlingtonia CALIFORNICA

Manuscript III:

ESTABliSHMENT OF A MiCROPROPAGATION SYSTEM FOR MEMBERS OF THE Carnivorous Plant Family Sarraceniaceae. III. Morphological Responses DURING IN VITRo REgeneration OF THE NORTH AMERICAN PITCHER PlantS DARLINGTONIA CALIFORNICA AND SARRACENIA PURPUREA 


\section{TABLE OF CONTENTS}

Page

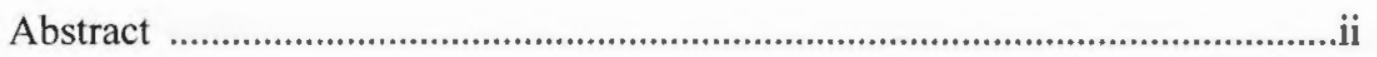

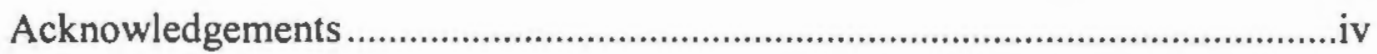

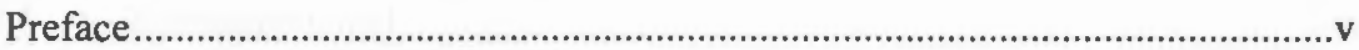

Table of Contents ..................................................................................

List of Figures ......................................................................................

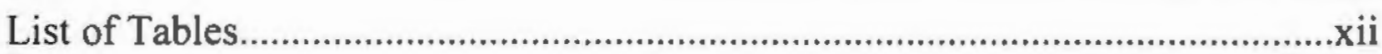

Manuscript I

ESTABLISHMENT OF A Micropropagation SySTEM FOR MEMBERS OF THE

Carnivorous Plant Family Sarraceniaceae. I. Surface Sterilization and IN

VItro Germination of SEEDS OF DARLINGTONIA CALIFORNICA WITH NOTES AND

OBSERVATIONS ON SARRACENIA LEUCOPHYLLA, S. ALATA, ANDS.

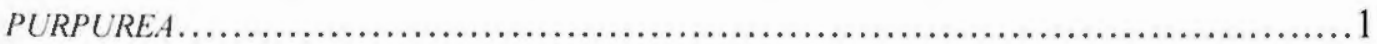




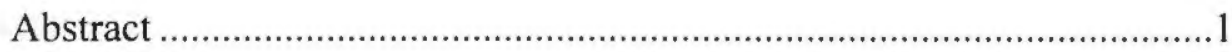

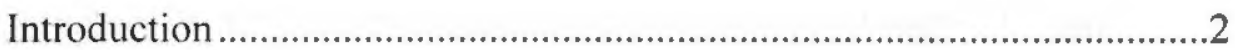

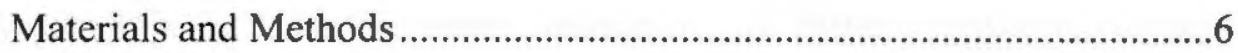

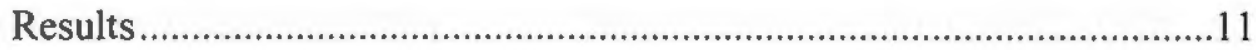

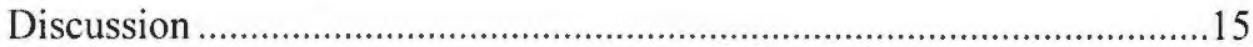

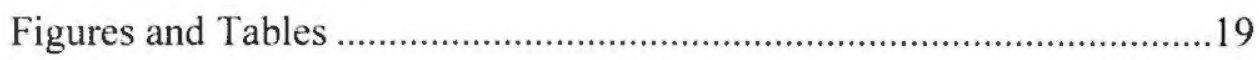

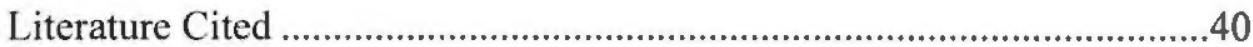

Manuscript II:

ESTABLISHMENT OF A MiCROPROPAGation SySTEM FOR MEMBERS OF THE

Carnivorous Plant Family Sarraceniaceae. II. IN Vitro Growth and Early Seedling Development of the North American Pitcher Plant Darlingtonia CALIFORNICA

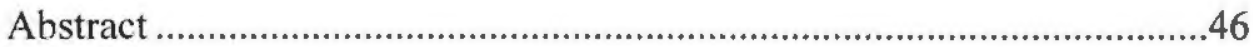

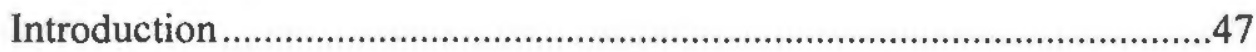

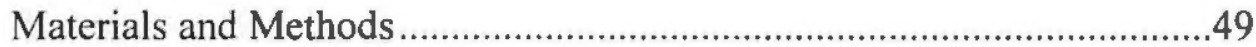

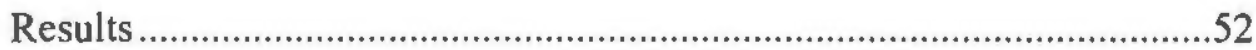

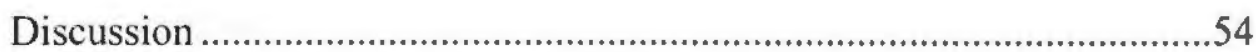

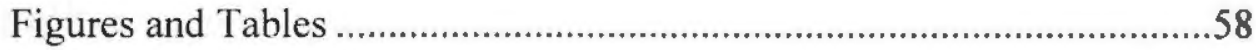

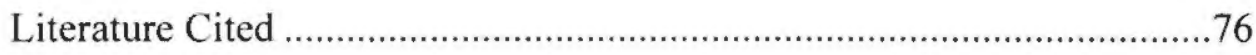




\section{Page}

Manuscript III:

ESTABLISHMENT OF A MICROPROPAGATION SYSTEM FOR MEMBERS OF THE

Carnivorous Plant Family Sarraceniaceae. III. Morphological Responses

During IN Vitro Regeneration of the North American Pitcher Plants

DARLINGTONIA CALIFORNIC AND SARRACENIA PURPUREA.

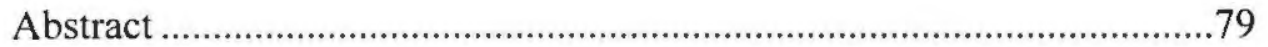

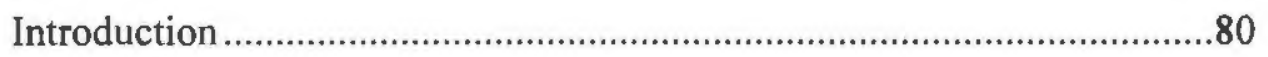

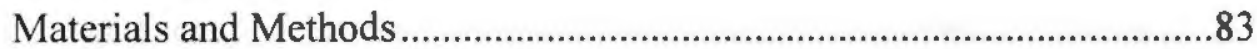

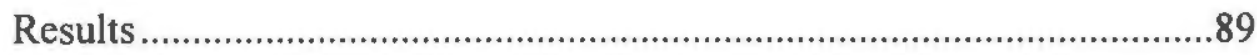

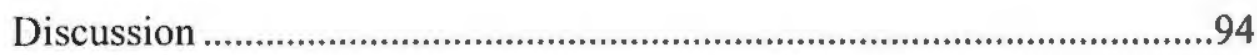

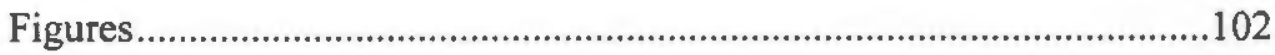

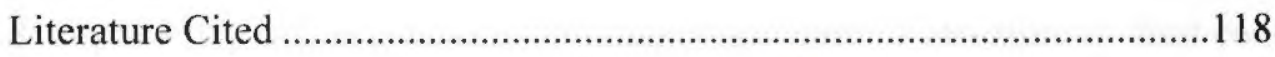

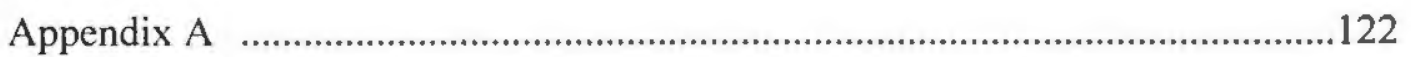

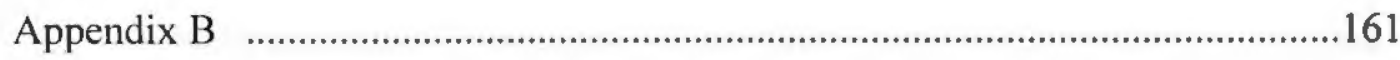

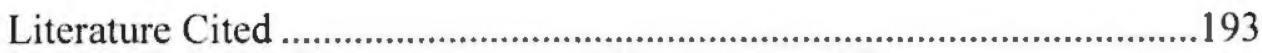

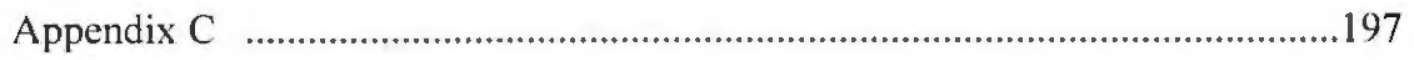

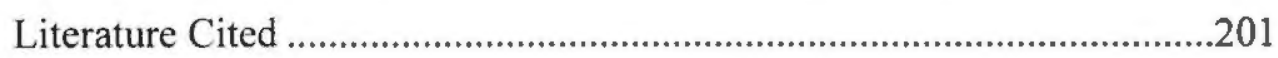

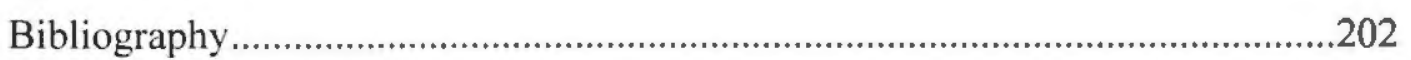


Page

\section{LIST OF FIGURES}

\section{Manuscript I}

1. Effect of time in sterilant on percent contamination of seeds of Sarracenia leucophylla after 15 days incubation on MYP medium in darkness at a constant temperature of $27^{\circ} \mathrm{C}$

2. SEM studies of seed surface of Darlingtonia californica 25

3. Surface topography of seeds of Sarracenia leucophylla 27

4. Seeds of Sarracenia leucophylla - internal structure 29

5. Seed coats of Darlingtonia californica and $S$. leucophylla after acid treatments

6. Seed surface topography of several Sarracenia species

7. Seed surface morphology of several species of Drosera 35

8. SEM study of seed surface topography and internal structure of seed coat of Dionaea muscipula (Venus Fly Trap).

9. Comparison of percent germination of seeds of D. californica in $\mathrm{H}_{2} \mathrm{O}$

(black) and liquid $1 / 2$ strength MS medium (gray) in two trials 38

10. Effect of pre-germinative treatment on percent germination of seeds of Darlingtonia californica after 21 days incubation 39 
Manuscript II

1. Effect of medium on number of pitchers produced by seedlings of

Darlingtonia californica after twelve weeks of growth on three different solid media .58

2. Effect of medium on length of pitchers produced by seedlings of Darlingtonia californica after twelve weeks growth on three different solid media

3. Darlingtonia californica seedlings after 12 weeks of growth 61

4. Darlingtonia californica seedlings after $6 \frac{1}{2}$ weeks of growth in liquid medium. 63

5. Darlingtonia californica seedlings - proliferation .65

6. Mean number of pitchers produced per flask per treatment by seedlings of Darlingtonia californica in $1 / 2$ and $1 / 4$ strength liquid MS medium with and without charcoal. 66

7. Mean length of pitchers produced per flask per treatment by seedlings of Darlingtonia californica in $1 / 2$ and $1 / 4$ strength liquid MS medium with and without charcoal. 67

8. Mean number of roots produced per flask per treatment by seedlings of Darlingtonia californica in $1 / 2$ and $1 / 4$ strength liquid MS medium with and without charcoal. .68

9. Root production on proliferating seedlings of Darlingtonia californica after $6 \frac{1}{2}$ weeks of growth in liquid media .70 
10. Root production of D. californica after $61 / 2$ weeks of growth in liquid medium. .72

11. Mean dry weight of plant tissue produced per flask per treatment by seedlings of Darlingtonia californica in $1 / 2$ and $1 / 4$ strength liquid MS medium with and without charcoal.

\section{Manuscript III}

1. Darlingtonia californica - Production of callus and protocorm-like bodies on semi-solid medium 103

2. Darlingtonia californica-Comparison of protocorm-like bodies with orchid protocorms- proliferating masses of pitchers and tissue

3. Darlingtonia californica- In vitro growth and multiplication

4. Darlingtonia californica - Growth in liquid medium

5. Darlingtonia californica- Morphogenic structures produced from fragmented pitchers

6. Darlingtonia californica-Multiplication and growth of protocorm-like bodies after subculture to liquid medium. 113

7. Darlingtonia californica- New growth from whole and fragmented pitchers in liquid medium containing auxin and cytokinin.

8. S. leucophylla - Seedlings, endosperm and embryos 


\section{LIST OF TABLES}

Page

Manuscript I

1. Methods of seed germination 19

2. Effect of three 5 min washes in sterile $\mathrm{H}_{2} \mathrm{O}$ on percent contamination of seeds incubated on MYP in the dark at $27^{\circ} \mathrm{C}$ 20

3. Percent contamination of unimbibed seeds of Darlingtonia californica following treatment in four different surface sterilants .21

4. Seeds of Sarracenia leucophylla. Chi-square analysis of time in concentrated $\mathrm{H}_{2} \mathrm{SO}_{4}$ indicates optimum effective treatment time for disinfestation of seed surface lies between 8-12 $\mathrm{min}$ .22

Manuscript II

1. Comparison of media formulations. .74

Appendix B 161

1. Taxonomic classification of carnivorous plants. 188

2. Carnivorous plants that have been cultured or propagated in vitro 189 


\title{
MANUSCRIPT I
}

\section{ESTABLISHMENT OF A MICROPROPAGATION SYSTEM FOR MEMBERS \\ OF THE SARRACENIACEAE}

I.

\author{
DISINFESTATION AND IN VITRO GERMINATION OF SEEDS OF THE \\ NORTH AMERICAN PITCHER PLANTS DARLINGTONIA CALIFORNICA \\ TORREY, SARRACENIA LEUCOPHYLLA RAF., AND S. PURPUREA L.
}

\begin{abstract}
A simple, efficient system for seed surface disinfestation and in vitro germination without lengthy seed stratification was developed for the carnivorous pitcher plants Darlingtonia californica and Sarracenia leucophylla. Of the disinfectants tested, hydrogen peroxide or $10 \%$ Clorox $®$ were most effective for disinfesting seeds of $D$. californica, while concentrated sulfuric acid worked best for S. leucophylla. Differences in the effectiveness of sterilants were associated by differences in seed coat morphology. Seeds of $D$. californica imbibed at $4-7^{\circ} \mathrm{C}$ in sterile deionized water with surfactant and gibberellin germinated earlier than seeds without exposure to gibberellin. Unimbibed seeds of $S$. leucophylla germinated rapidly in sterile water after treatment in concentrated sulfuric acid. Scanning electron microscopy of $D$. californica seed coats revealed waxy trichomes covering the seed surface. In contrast, the seed coats of S. leucophylla were pitted with surface and subsurface cells possessing heavily thickened cell walls. These cells were devoid of contents. Fungal hyphae were observed on the seed surface and within empty cells of
\end{abstract}


the integuments. Scanning electron microscopy observations and comparison of seed coat morphology ofmembers of the carnivorous plant genera Drosera, Dionaea, Sarracenia and Darlingtonia revealed differences in structure and ornamentation, which may suggest species-specific approaches to surface disinfestation.

\section{INTRODUCTION}

Since the time of Darwin the various genera of carnivorous plants have fascinated both botanists and plant enthusiasts (see Lloyd, 1942, for early references). Their many unique anatomical and physiological adaptations peculiar to the carnivorous habit continue to attract attention from workers in such diverse areas as developmental biology, ecology, cell biology, micropropagation and evolutionary biology.

This artificially grouped assemblage of plants comprises more than 600 species (Adamec, 1997) and has grown considerably since 1989 when Givnish reported 538 species (Table 1, Appendix B). Taxonomically, species of carnivorous plants occur in nine families and 19 genera (Table1, Appendix B). Micropropagation of members of this group is desirable for several reasons. Several members of the genus Drosera and the related monotypic genus Dionaea are a source of medicinal compounds (Bobak et al., 1995; Bobak et al., 1993; Budzianowski, 2000, 1996, 1995a, 1995b; Crouch et al., 1990; Hook, 2001; and Zenk and Steglish, 1969). Additionally, extracts of the roots of Sarracenia flava possess antitumor activity against certain forms of human cancer cells (Miles et al., 1974). Collection pressure and/or habitat destruction has reduced or depleted many natural populations of carnivorous plants in the wild (Anthony, 1992; 
containing levels of nickel, zinc, chromium and other metals that are generally phytotoxic makes it extremely interesting and appropriate for the study of what may be unique developmental and physiological processes. S. leucophylla is an American pitcher plant found on the lower Gulf Coast of the United States in Georgia, Florida, Alabama and Mississippi.

Although several species of carnivorous plants have been micropropagated (see appendix C this dissertation), work on members of the Sarraceniaceae has been limited. A search of the literature revealed only two papers on their in vitro culture. Withner (1964) reported qualitative observations on applying the techniques of orchid culture to D. californica and S. purpurea. D. californica also was included in a broad survey of the feasibility of micropropagation of carnivorous plants (Boulay, 1995). Until recently few reports have addressed the germination of seeds of carnivorous plants, particularly members of the Sarraceniaceae. Prior to the publication of Ellison's (2001) extensive study on the germination of 8 species of Sarracenia, the literature contained only two papers (not including Withner's note) on the germination of seeds of only one specie, S. purpurea (Mandossian, 1966; Gotsch and Ellison, 1998). No micropropagation systems for the Sarraceniaceae have been described in the literature. This is surprising since many of the species that are offered commercially have been propagated by tissue culture. The lack of published information on propagation of these species likely reflects the concerns of commercial producers who consider such techniques proprietary (a brief search of the web on 4/12/03 found four commercial suppliers offering carnivorous plant species from tissue culture including members of the genera Sarracenia, Heliamphora, and 
Nepenthes). I feel that development of such systems and publication of the protocols will help alleviate collection pressure in the wild and offer other workers in the field methods that may facilitate the study of developmental, physiological, and ecological questions whose answers may be found within the unique adaptations and habit of this marvelous group of plants.

This manuscript reports on the initial steps in the establishment of a micropropagation system for members of the carnivorous plant family Sarraceniaceae. 
wash, seeds were resuspended in $2-3 \mathrm{ml}$ of sterile deionized water and transferred to sterile glass petri dishes. Fine forceps or a sterile bacterial loop was used to transfer the seeds (one per well) to individual wells of 12 or 24 -well sterile plastic culture plates (Sigma, St. Louis, Missouri) with each well containing $2 \mathrm{ml}$ of sterile MYP (malt extract, $7.0 \mathrm{~g} / \mathrm{l}$; yeast extract, $0.5 \mathrm{~g} / 1$; bacto-peptone, $1.0 \mathrm{~g} / 1$; Koske, 1977) and $10 \mathrm{~g} / \mathrm{l}$ sucrose. Medium $\mathrm{pH}$ was adjusted to 6.5 with $\mathrm{KOH}$ before the addition of 9.5 g/l Bacto-agar (Difco, Detroit, Michigan) and autoclaved at $121^{\circ} \mathrm{C}$ for $15 \mathrm{~min}$. Fortyeight seeds were used in each treatment. Experiments were repeated twice using two different seed lots for each species. Seeds were purchased in 2001 and 2002 respectively. All seeds were collected by the supplier in the fall of each year and stored at $4-7^{\circ} \mathrm{C}$ prior to shipment (personal communication, Peter Paul's Nurseries, Canadaigua, NY). Culture plates were wrapped in Saran Wrap $®$ brand plastic wrap (Dow Brands, Indianapolis, Indiana), sealed in a Rubbermaid@ container (Newell Rubbermaid Inc., Freeport, Illinois) and placed in a dark growth chamber at a constant temperature of $27^{\circ} \mathrm{C}$. Cultures were examined for signs of contamination with the aid of a dissecting microscope daily or every other day for a period of 15 days . Additionally, 48 seeds of $S$. purpurea and 24 seeds each of S. flava, S. alata and $S$. rubra were subjected to the sterile wash series in treatment $\# 5$ as described above.

\section{Scanning Electron Microscopy}

For surface studies, seeds of Darlingtonia, Sarracenia, Drosera and Dionaea spp. were air-dried for $24 \mathrm{~h}$ then sputter-coated with gold during rotation for 90-160 s. For internal studies, seeds were cut in half or into sections using a razor blade or fine pointed surgical scalpel and a dissecting microscope. Any residual endosperm or 
embryonic tissue was removed using a fine pointed dental pick. Cut seeds were airdried for $24 \mathrm{~h}$, fixed to double sided tape (Scotch) on microscope coverslips, sputter coated with gold and attached to the stage mount with double sided tape. Seeds of $D$. californica and $S$. leucophylla also were treated for $4,8,12$, and $16 \mathrm{~min}$ in concentrated $\mathrm{H}_{2} \mathrm{SO}_{4}$, rinsed 3 times in sterile deionized water and air-dried for $24 \mathrm{~h}$ before being prepared for SEM as described above. Observations were made with an Hitachi 4100 Scanning Electron Microscope (Hitachi, Ltd., Toyo, Japan). Images were captured using a Sunspark Image Capture System (Sun Microsystems Inc., Santa Clara, California).

\section{Seed Germination Studies}

Six methods used to germinate seeds are summarized in table \#1. Germination was scored by emergence of the radicle.

\section{Germination of Unimbibed Seeds in Liquid Culture}

Seeds of $D$. californica and S. leucophylla were surface-disinfested for 10 and 20 min, respectively, in 10\% Clorox $₫$ solution (Method \#1, Table 1) and rinsed.

Alternatively, seeds of $D$. californica and $S$. leucophylla were treated in concentrated $\mathrm{H}_{2} \mathrm{SO}_{4}$ for $4 \mathrm{~min}$ and $10 \mathrm{~min}$, respectively, and rinsed (Method \#2, Table \#1).

Following the last wash, seeds were poured (along with 1-2 ml of water) onto sterile filter paper in a sterile petri dish and transferred, with fine forceps or a bacterial loop, to $50 \mathrm{ml}$ Erlenmeyer flasks (six seeds per flask, six flasks per treatment) containing 1) $5 \mathrm{ml}$ of sterile $\mathrm{H}_{2} \mathrm{O}(\mathrm{pH} 5.0$ ) or 2) $5 \mathrm{ml}$ of liquid $1 / 2$ strength Murashige and Skoog (MS) salts + MS vitamins $+20 \mathrm{~g} / \mathrm{l}$ sucrose (Murashige and Skoog, 1962). The flasks were placed on a gyrotary shaker at $120 \mathrm{rpm}$ under room temperature and lighting 
conditions (diffuse light, $23^{\circ} \mathrm{C} \pm 3^{\circ}$ ). All transfers were performed in a laminar flow hood. With the exception of the acid treatment for $D$. californica, experiments were repeated twice.

Germination Studies on Unimbibed, Cold-Imbibed, and GA 3 -Stimulated Seeds of D. californica on Semi-Solid $\mathrm{H}_{2} \mathrm{O}$ Agar Medium

Seeds were subjected to 3 treatments: unimbibed (Method \#3, Table 1), imbibed (Method \#4 Table 1), and imbibed with $6 \mathrm{mg} / 1 \mathrm{GA} 3$ (Method \#5, Table 1). Surface-disinfestation time was 10 min in $\mathrm{H}_{2} \mathrm{O}_{2}$. After disinfestation seeds were transferred ( 25 seeds each) to nine, $15 \mathrm{~mm} \times 100 \mathrm{~mm}$ plastic petri dishes ( 3 per treatment) containing $25 \mathrm{ml}$ of water agar. Incubation was at room temperature and room lighting conditions as described above. Observations were made daily until first germination was observed, then every other day for a period of 21 days. The experiment was repeated twice.

Germination of Seeds of S. leucophylla, S. alata, and S. purpurea Following ColdImbibition and Treatment In Concentrated $\mathrm{H}_{2} \mathrm{SO}_{4}$

Seeds of S. leucophylla, S. alata, and S. purpurea were prepared by method \#6 (Table 1) and transferred (1 each) to individual wells of 12-well-plastic culture plates containing $3 \mathrm{ml}$ of either sterile deionized $\mathrm{H}_{2} \mathrm{O}$ or Phytomax Orchid Multiplication Medium (POMM, Sigma, St. Louis MO). Culture plates were sealed with Parafilm $®$ (American National Can, Menasha, Wisconsin) and placed in a growth chamber at $27^{\circ} \mathrm{C} \pm 2^{\circ}$ with $16-\mathrm{hr} \mathrm{d}^{-1}$ illumination at $170 \mu \mathrm{mol} \mathrm{m}^{-2} \mathrm{sec}^{-1}$. 


\section{Effect of Scarification on Germination of Seeds of $D$. californica}

The micropylar regions of 30 seeds of $D$. californica were removed with the aid of a dissecting microscope and fine pointed scalpel, and seeds were then subjected to Method \# 3 (Table 1) and incubated at room temperature and light. The experiment was repeated twice.

\section{Statistical Analysis}

Results of sterile $\mathrm{H}_{2} \mathrm{O}$ wash and surface sterilant treatments are reported as percent contaminated seeds after 15 days incubation on MYP. Treatments were compared using chi-square analysis with Yates correction (Schefler, 1979) of number of seeds contaminated after 15 days incubation and the number of seeds not contaminated. Data for germination in liquid medium were analyzed by converting number of seeds germinated after 21 days to percent. Percentages were transformed using arc sin transformation. T-tests were performed on the transformed data. Analysis of germination data from solid media experiments was performed with ANOVA followed by Fisher Post-Hoc tests. Comparisons of early and late germination between treatments were made with chi-square analysis of number of seeds germinated on day 15 vs. total number germinated after 21 days. ANOVA, t-test and transformations were performed with Statview 5.0 (Statview: Using Statview SAS Third Edition, 1999). Chi Square analysis was performed with a program provided by Dr. R. Koske (Dept. of Biological Sciences, URI). 


\section{RESULTS:}

\section{Surface Disinfestation - Sterile Wash}

In all species washing with sterile water generally was ineffective for obtaining sterile seed material (Table \#2). However, in some trials, surface disinfestation of seeds of $D$. californica was achieved with a sterile $\mathrm{H}_{2} \mathrm{O}$ wash (Table 2 , Trials 2 , and 3 ).

\section{Treatment in Surface Sterilants}

Seeds of $D$. californica could be surface disinfested with all sterilants tested using exposure times as low as $4 \mathrm{~min}$ (Table 3 ). In contrast, seeds of S. leucophylla remained contaminated regardless of the treatment or exposure time (Table 3). Treatment of $S$. leucophylla in concentrated $\mathrm{H}_{2} \mathrm{SO}_{4}$ resulted in a consistent reduction in percent of contaminated seeds as exposure time in sterilant increased (Figure 1). A similar linear decrease in contamination was observed in response to treatment with Physan 20, but in much smaller increments, and the contamination rate remained high. Both 10\% Clorox® and 3\% hydrogen peroxide were inconsistent sterilants.

Contamination sometimes spiked as time in sterilant increased (Fig.1). Chi-square analysis of treatment times for $S$. leucophylla seeds with concentrated $\mathrm{H}_{2} \mathrm{SO}_{4}$ suggested that optimum treatment time was between 8 and $12 \min$ (Table 4).

\section{Scanning Electron Microscopy}

Dry seeds of $D$. californica are "tear-drop" shaped with finger-like trichomes on the seed surface (Fig. 2A). Erect trichomes (those with their long axis perpendicular to the long axis of the seed) were most numerous at the chalazal end of the seed (Fig. 2B) and diminished in density toward the tapering micropylar region 
Seed coats of $S$. purpurea, $S$. flava, and $S$. rubra were similar to those of $S$. leucophylla in surface topography (Figs. 6A-H). In these species fungal hyphae, sporangia and spores were frequently observed on the surfaces of many of the seeds (Figs. 6i and j) or appeared to be growing out of damaged surface cells (Fig. 6J). In contrast, seeds of Drosera species showed considerable interspecific variation in surface topography (Figs. 7A-J). The surface of Dionaea muscipula seeds (Figs. 8A H) was relatively smooth (Fig. 8A) with slight bulges in the outer periclinal wall of surface cells giving the seed coat surface a "cobblestone" appearance (Fig. 8B). The outermost layer of the seed coat was characterized by hollow, heavily sclerified cells (Fig. 8C) with thick anticlinal walls (Fig. 8D). The periclinal surface was covered by a thick, homogeneous, extracellular matrix (Fig. 8E). Although the seed coat layers appeared more impenetrable than in any of the other genera examined, evidence of fungal infection was observed (Figs. 8F and $\mathrm{G}$ ). When viewed in paradermal section the interior of the seed coat had a honeycombed appearance (Fig. 8H).

\section{Germination Studies in Liquid Medium}

Germination of seeds of $D$. californica in water (Method \#1, Table 1) was significantly greater than in $1 / 2$ strength $\mathrm{MS}(\mathrm{P}=0.006$ and $\mathrm{P}=0.004$ respectively for two trials) at 21 days of incubation (Fig. 9). The number of seeds germinated on day 15 vs. the total number germinated by day 21 was significant at $P=0.01$ (chi square $=$ 8.517) and $\mathrm{P}=0.05$ (chi-square $=6.23$ ) respectively for trials 1 and 2 . Seeds of $D$. californica treated in $\mathrm{H}_{2} \mathrm{SO}_{4}$ (Method \#2, Table 1) failed to germinate after 21 days of incubation. 
Seeds of $S$. leucophylla could not be surface-sterilized in quantities required for further experiments. For instance, in one trial, contamination appeared early in 5 of 6 flasks containing 6 seeds each. Appearance of contamination sometimes followed germination and seeds germinated even in contaminated flasks (see Appendix A, Ancillary Results to Manuscript 1 for data on S. leucophylla). S. leucophylla showed $11.5 \%$ germination in $\mathrm{H}_{2} \mathrm{O}$ after 21 days compared to no germination in liquid $1 / 2$ strength MS in the only trial that produced usable data. Germination on solid $1 / 2$ strength MS was not determined due to contamination in all flasks. Further work with S. leucophylla was limited to work with 3 seedlings that had germinated in one uncontaminated flask of 6 seeds in $\mathrm{H}_{2} \mathrm{O}$.

\section{Germination on Semi-Solid $\mathrm{H}_{2} \mathrm{O}$ Agar Medium}

The response of seeds of $D$. californica varied widely between germination Methods \#3, \#4 and \#5. The highest percent germination ( $80 \%)$ was observed in seeds receiving cold-imbibition and $\mathrm{GA}_{3}$ stimulation before germination (Fig. 10). All treatments differed significantly from each other $(\mathrm{P}=0.0005)$.

Germination of Seeds of S. leucophylla, S. alata, and S. purpurea Following Cold Imbibition and Treatment in Concentrated $\mathrm{H}_{2} \mathrm{SO}_{4}$

Seeds of $S$. leucophylla, S. alata, and $S$. purpurea failed to germinate after 60 days of incubation in a growth chamber with temperature and light conditions as previously described.

Effect of Scarification on Germination of $D$. californica

Germination of scarified seeds was $70 \%$ and $77 \%$ respectively after 21 days in two trials (data not shown- see Appendix A). 


\section{DISCUSSION}

\section{Surface Disinfestation}

The very high effectiveness of the variety of sterilants tested for surface disinfestation of the seeds of $D$. californica was unexpected. SEM observations of the seed coat revealed a surface morphology that presented opportunity for the collection and adherence of spores of microorganisms. Also, seeds of $D$. californica have been reported as difficult to disinfest (Boulay, 1995). A lack of contamination during incubation of $D$. californica seeds was observed in preliminary experiments (data not shown). In addition, when data from the sterile wash series were collected, it became apparent that seed surfaces were either remarkably free of microorganisms or could be made free of them with a simple wash. The use of 3 different seed lots in these experiments suggests that this phenomenon is not seed-lot specific. Although all sterilants tested were effective, $10 \%$ Clorox@ and $3 \% \mathrm{H}_{2} \mathrm{O}_{2}$ were selected for use in subsequent experiments with $D$. californica because of their consistent effectiveness. Physan 20 was rejected after seeds disinfested in a $10 \%$ solution failed to germinate. Similarly, concentrated $\mathrm{H}_{2} \mathrm{SO}_{4}$ was rejected after seeds treated for 4 min failed to germinate (see Appendix A). SEM observations showed that seed coat integrity had been compromised by the acid.

In contrast, seeds of $S$. leucophylla were difficult to disinfest in quantity using the 4 sterilants tested. Although difficulty in disinfestation of explanted organ tissues from several species of carnivorous plants has been reported (Anthony, 1992; Crouch et al., 1990; Minocha, 1985), reports of difficulty in disinfestation of seeds used as initial explant material for culture of carnivorous plants has been limited (see Table 3, 
Appendix A). The inability to effectively disinfest seeds of $S$. leucophylla may result from endophytes present within the seed coat or pathogens that gained entry during or after its maturation. SEM observations revealed fungal hyphae traversing the seed coat surface of $S$. leucophylla (Figs. 3F and I). Fungal hyphae and sporangia were also observed emerging from damaged cells of the seed surface of $S$. purpurea (Fig. $6 \mathrm{~J}$ ) and the micropylar region of the seed coat of Dionaea muscipula (Fig. 8E). This implies that they are not in the category of surface organisms, thus rendering surface sterilization insufficient as a disinfestation treatment for these seeds.

The effectiveness of $\mathrm{H}_{2} \mathrm{SO}_{4}$ as a disinfectant for seeds of $S$. leucophylla may have resulted from its ability to successively dissolve the seed coat layers (Figs. 3C-H) and reach previously sheltered endophytes or their spores. In preliminary experiments (data not shown) several species of Drosera and Dionaea muscipula were easily disinfested with $3 \% \mathrm{H}_{2} \mathrm{O}_{2}$. Ease of disinfestation was most likely due to the unornamented outer layers of their seed coats as observed in SEM (Figs.7F and I; Fig.8A).

Contamination of explanted tissue of carnivorous plants has sometimes been attributed to the presence of endophytic organisms (Perica and Berljak, 1996; Anthony, 1992). Although the literature contains many reports of endophytes in noncarnivorous plants (e.g. White et al., 1993, 1986; Carroll, 1988; Hinton and Bacon, 1984), to my knowledge no investigations of endophytes in carnivorous plants have been reported. 


\section{Germination Studies}

The rapid germination of unimbibed seeds of $D$. californica in $\mathrm{H}_{2} \mathrm{O}$ and coldimbibed seeds in $\mathrm{H}_{2} \mathrm{O}$ agar is both surprising and fortuitous. Horticultural literature suggests that germination of seeds of $D$. californica requires a cold treatment of up to 2 months (Lecoufle, 1990; Pietropaolo and Pietropaolo, 1986). Earlier observations by Withner (1964) reported the failure of mature seeds of $D$. californica to germinate under laboratory conditions when sown immediately after collection; successful germination was only achieved through the use of immature seeds from green seed capsules. The research reported in this manuscript shows that cold imbibition of mature seeds of $D$. californica for $24 \mathrm{~h}$ in $\mathrm{H}_{2} \mathrm{O}$ results in high germination percentages within 21 days. This rapid germination may be the result of the role of cold imbibition in breaking seed dormancy (Vidaver, 1977).

Seeds of S. leucophylla, S. alata and S. purpurea failed to germinate if cold imbibed prior to disinfestation in concentrated $\mathrm{H}_{2} \mathrm{SO}_{4}$. These results confirm observations by Ellison (2001). However, unimbibed seeds of S. leucophylla germinated when treated for $10 \mathrm{~min}$ in concentrated $\mathrm{H}_{2} \mathrm{SO}_{4}$ (see Appendix $\mathrm{B}$ ) and incubated in $\mathrm{H}_{2} \mathrm{O}$.

Because sufficient numbers of seedlings can be produced without $\mathrm{GA}_{3}$ stimulation, use of the hormone is not warranted for the production of seedlings for research because the effect of $\mathrm{GA}_{3}$ on seedling morphology and its long-term effect on growth still require investigation. Similarly, because of the labor required, surgical removal of the micropylar pole of seeds was not considered to be worthwhile in establishment of this micropropagation system. 


\section{Summary}

Based on the results of this investigation, protocols for the disinfestation and axenic germination of seeds of $D$. californica have been established. Additionally, this study indicates a possible relationship between seed coat morphology and ease of seed disinfestation. 
Table \# 1. Methods used for seed germination

\begin{tabular}{|c|c|c|c|c|c|c|c|c|c|c|c|c|}
\hline \multirow{2}{*}{$\begin{array}{c}\text { Method } \\
\#\end{array}$} & \multicolumn{3}{|c|}{ Pre-Germinative Treatment } & \multicolumn{4}{|c|}{ Sterilants for Surface Disinfestation** } & \multicolumn{5}{|c|}{ Germination Medium*** } \\
\hline & $\begin{array}{c}\text { Not } \\
\text { imbibed }\end{array}$ & Imbibed* & $\begin{array}{c}\text { Imbibed }^{*} \\
+6 \mathrm{mg} / 1 \\
\mathrm{GA}_{3}\end{array}$ & $\begin{array}{c}3 \% \\
\mathrm{H}_{2} \mathrm{O}_{2}\end{array}$ & $\begin{array}{c}10 \% \\
\text { Clorox }\end{array}$ & $\begin{array}{l}\text { Conc. } \\
\mathrm{H}_{2} \mathrm{SO}_{4}\end{array}$ & $\begin{array}{l}3 \times 5 \mathrm{~min} \\
\text { sterile } \\
\text { washes }\end{array}$ & $\mathrm{H}_{2} \mathrm{O}$ & $\begin{array}{l}\mathrm{H}_{2} \mathrm{O} \\
\text { agar }\end{array}$ & $\begin{array}{l}\text { Liq. } 1 / 2 \\
\text { Strength } \\
\text { MS**** }\end{array}$ & $\begin{array}{l}\text { Solid } 1 / 2 \\
\text { Strength } \\
\text { MS**** }\end{array}$ & $\begin{array}{c}\mathrm{POMM} \\
* * * * *\end{array}$ \\
\hline 1 & $\mathrm{X}$ & & & & $\mathrm{X}$ & & $\mathrm{X}$ & $\mathrm{X}$ & & $\mathrm{X}$ & & \\
\hline 2 & $\mathrm{X}$ & & & & & $\mathrm{X}$ & $\mathrm{X}$ & $\mathrm{X}$ & & $\mathrm{X}$ & & \\
\hline 3 & $\mathrm{X}$ & & & $\mathrm{X}$ & & & & & $\mathrm{X}$ & & & \\
\hline 4 & & $X$ & & $\mathrm{X}$ & & & & & $\mathrm{X}$ & & & \\
\hline 5 & & & $\mathrm{X}$ & $\mathrm{X}$ & & & & & $\mathrm{X}$ & & & \\
\hline 6 & & $\mathrm{X}$ & & & & $\mathrm{X}$ & $\mathrm{X}$ & $\mathrm{X}$ & & & & $\mathrm{X}$ \\
\hline 7 & & $\mathrm{X}$ & & $\mathrm{X}$ & & & & & $\mathrm{X}$ & & & \\
\hline 8 & & $\mathrm{X}$ & & $\mathrm{X}$ & & & & & & & $\mathrm{X}$ & \\
\hline
\end{tabular}

All seeds were stored unimbibed at $4-7^{\circ} \mathrm{C}$ prior to use in any treatment (experiments with each seed lot were conducted over a 3-4 month period).

* For $24 \mathrm{~h}$ in $10 \mathrm{ml} \mathrm{H} \mathrm{H}_{2} \mathrm{O}+1$ drop Tween 20 at $4-7^{\circ} \mathrm{C}$

** 1 drop Tween 20 added to all sterilants except washes

*** Adjusted to $\mathrm{pH} 5.0$

**** Murashige and Skoog (1962)

*****Phytomax Orchid Multiplication Medium (Sigma, St. Louis MO) 
Table \# 2. Effect of three 5 min washes in sterile $\mathrm{H}_{2} \mathrm{O}$ on percent contamination of seeds incubated on MYP in the dark at $27^{\circ} \mathrm{C}$.

\begin{tabular}{|l|l|c|c|l|}
\hline Trial \# & \multicolumn{1}{|c|}{ Species } & $\begin{array}{c}\text { \# of } \\
\text { Seeds }\end{array}$ & $\begin{array}{c}\text { \% } \\
\text { Contamination }\end{array}$ & \multicolumn{1}{|c|}{ Days* } \\
\hline 1 & Darlingtonia californica & 48 & 35.4 & 15 \\
\hline 2 & & & 2.1 & 15 \\
\hline 3 & & & 15 & $20 * *$ \\
\hline 1 & Sarracenia leucophylla & 48 & 100 & 7 \\
\hline 1 & S. purpurea & 48 & 94 & 15 \\
\hline 1 & S. alata & 24 & 100 & 7 \\
\hline 1 & S. flava & 24 & 75 & 15 \\
\hline 1 & S. rubra & 24 & 2.1 & 15 \\
\hline 2 & & 24 & 100 & 15 \\
\hline
\end{tabular}

- Experiments were run for 15 days, if all seeds contaminated earlier that time is noted.

** This experiment showed $15 \%$ contamination on day 15 . No new contamination had occurred by day 20 . 
Table \# 3. Percent contamination of unimbibed seeds* of Darlingtonia californica following treatment in four different surface sterilants.

\begin{tabular}{|c|c|c|c|c|}
\hline \multirow[t]{2}{*}{ Treatment } & \multicolumn{4}{|c|}{$\begin{array}{l}\text { Time in sterilant and } \% \text { contamination after } 15 \text { days incubation on } \\
\mathrm{MYP}+10 \mathrm{~g} / \mathrm{l} \text { sucrose at } 27^{\circ} \mathrm{C} \text { in constant darkness }\end{array}$} \\
\hline & $4 \min$ & $8 \mathrm{~min}$ & $12 \mathrm{~min}$ & $16 \mathrm{~min}$ \\
\hline $\begin{array}{l}3 \% \text { hydrogen } \\
\text { peroxide }\end{array}$ & 0 & 0 & 0 & 2.1 \\
\hline $10 \%$ Clorox & 0 & 0 & 0 & 0 \\
\hline $\begin{array}{l}\text { Concentrated } \\
\text { sulfuric acid }\end{array}$ & 0 & 0 & 0 & 0 \\
\hline $1.5 \%$ Physan & 0 & 0 & 0 & 0 \\
\hline \multicolumn{5}{|c|}{ Sarracenia leucophylla } \\
\hline $\begin{array}{l}3 \% \text { hydrogen } \\
\text { peroxide }\end{array}$ & 65.0 & 100 & 50.0 & 44.0 \\
\hline $10 \%$ Clorox & 17.0 & 8.3 & 93.0 & $\overline{8.3}$ \\
\hline $\begin{array}{l}\text { Concentrated } \\
\text { sulfuric acid }\end{array}$ & 52.1 & 40.0 & 14.6 & 6.3 \\
\hline $1.5 \%$ Physan & 91.7 & 7.8 & 67.0 & 63.0 \\
\hline
\end{tabular}

* 48 seeds were used in each treatment 
Table \# 4. Seeds of Sarracenia leucophylla. Chi-square analysis of time in concentrated $\mathrm{H}_{2} \mathrm{SO}_{4}$ indicates optimum effective treatment time for disinfestation of seed surface lies between 8-12 min.

\begin{tabular}{|c|c|c|c|}
\cline { 2 - 4 } \multicolumn{1}{c|}{} & 8 minutes & 12 minutes & 16 minutes \\
\hline 4 minutes & $\mathrm{NS}$ & $\mathrm{S}(\mathrm{P}=0.01)$ & $\mathrm{S}(\mathrm{P}=0.01)$ \\
\hline 8 minutes & & $\mathrm{S}(\mathrm{P}=0.05)$ & $\mathrm{S}(\mathrm{P}=0.01)$ \\
\hline 12 minutes & & & $\mathrm{NS}$ \\
\hline
\end{tabular}

$\mathrm{S}=$ significantly different

NS = not significantly different 


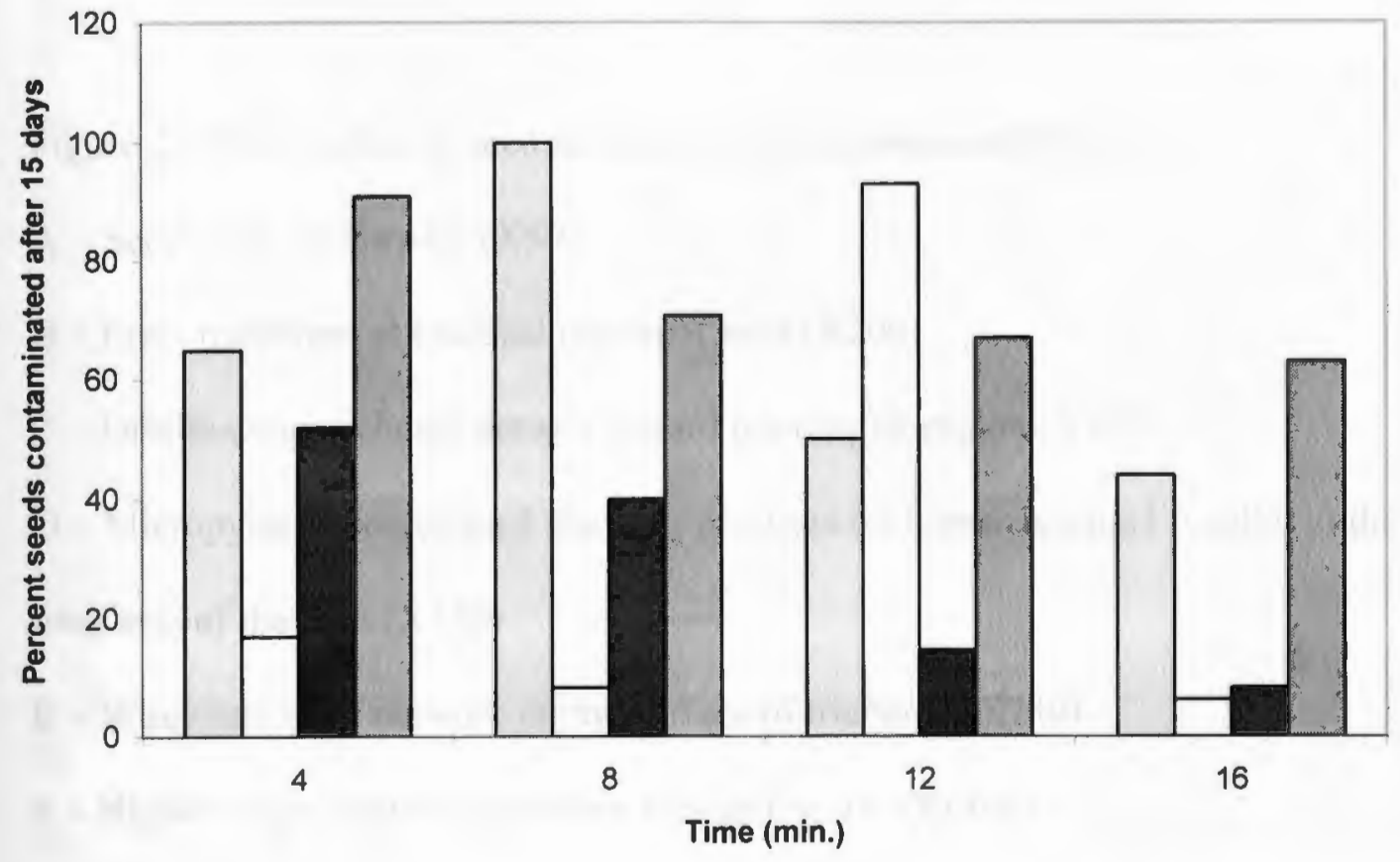

Figure 1. Effect of time in sterilant on percent contamination of seeds of Sarracenia leucophylla after 15 days incubation on MYP medium in darkness at a constant temperature of $27^{\circ} \mathrm{C}$. $3 \% \mathrm{H}_{2} \mathrm{O}_{2}$ (gray bars); $10 \%$ Clorox (white bars); $\mathrm{H}_{2} \mathrm{SO}_{4}$ (black bars); $1.5 \%$ Physan 20 (dark gray bars) 
Figure 2. SEM studies of seed surface of Darlingtonia californica A - Seed of $D$. californica (X50)

B - Erect trichomes at chalazal region of seed (X200)

C-Diminishing trichome density toward micropylar region (X150)

D - Micropylar region of seed showing prostrate trichomes oriented parallel to the long axis of the seed (X150)

E - Waxy reticulate network on the surface of trichome (X780)

F - Higher magnification of surface seen in Fig. 1E (X1400)

$\mathrm{G}$ - Polka-dot appearance of seed surface (X180) 


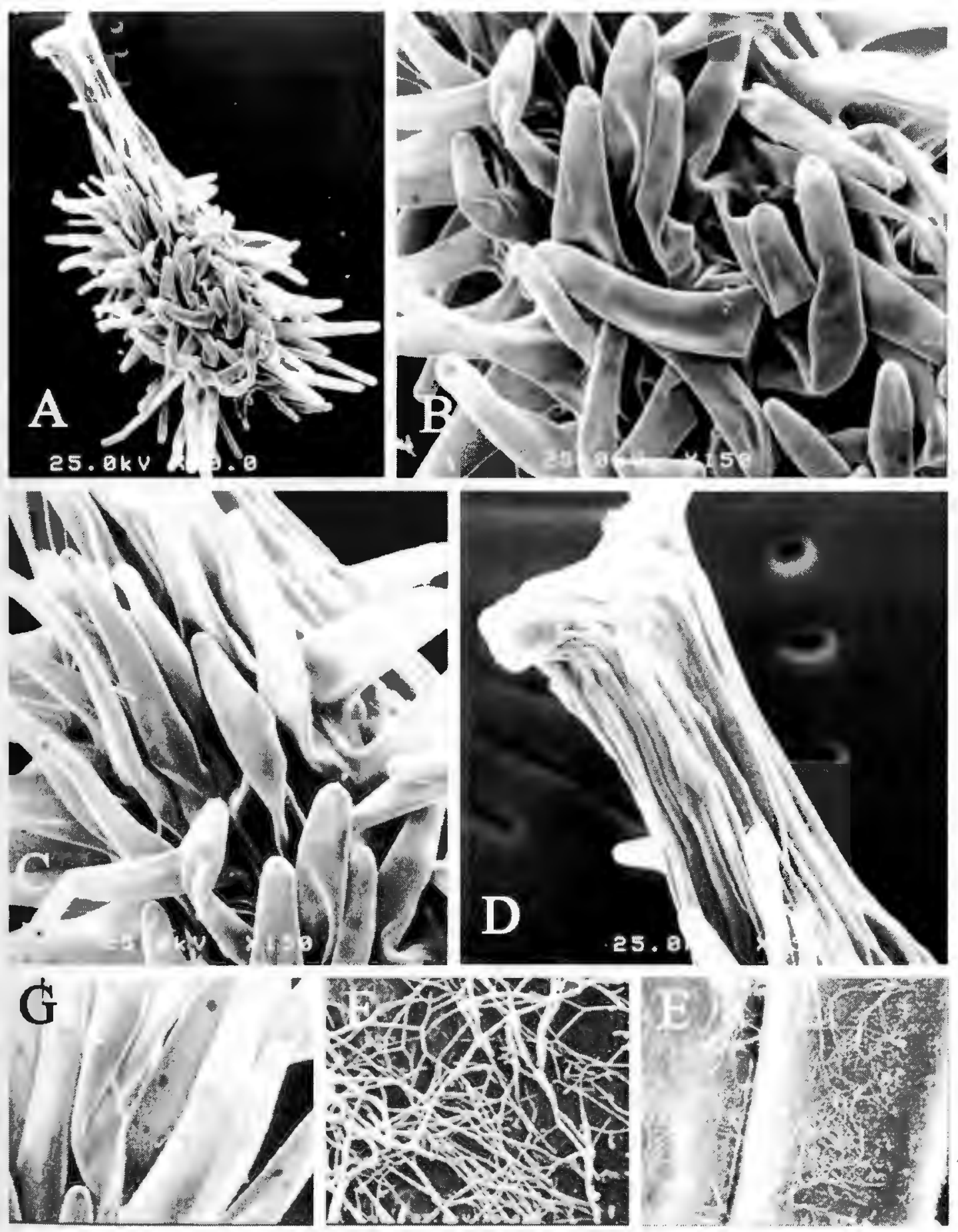


Figure 3. Seeds of Sarracenia leucophylla - Surface Topography

A- D - Seed surface morphology various orientations (X21)

E - Pitted appearance of surface (X50)

F - Collapsed periclinal walls of outer seed coat (X360)

G - Waxy covering of surface (X1900)

$\mathrm{H}$ - Waxy covering at higher magnification (X4000)

I - Fungal hyphae on seed surface (X300) 

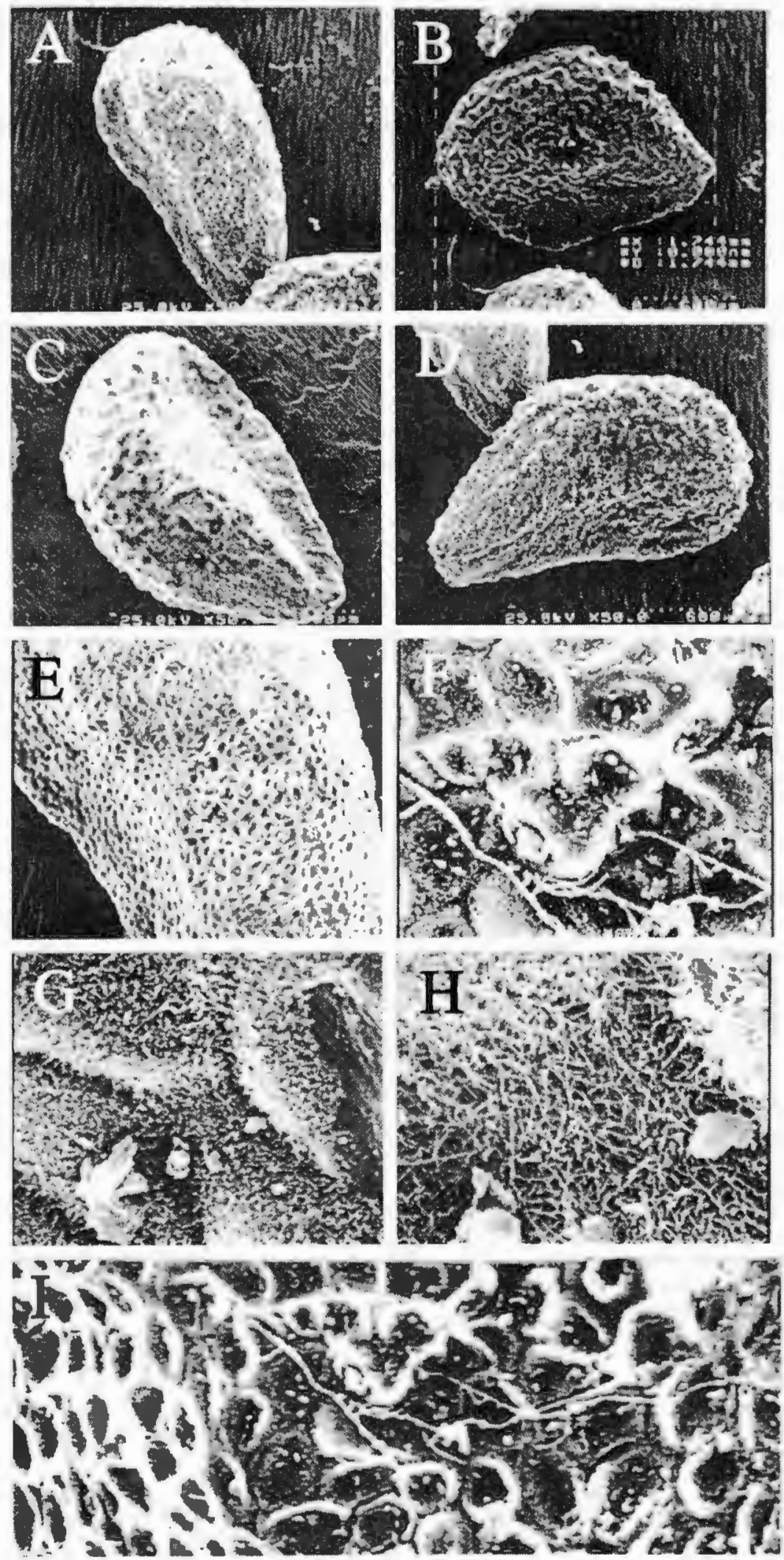
Figure 4. Seeds of Sarracenia leucophylla - Internal Structure

A - Multilayered coat at chalazal pole of seed and single layer parallel to long axis of the seed $(\mathrm{X} 117)$

B - Multilayered coat at micropylar pole showing hollow cells (X187) 

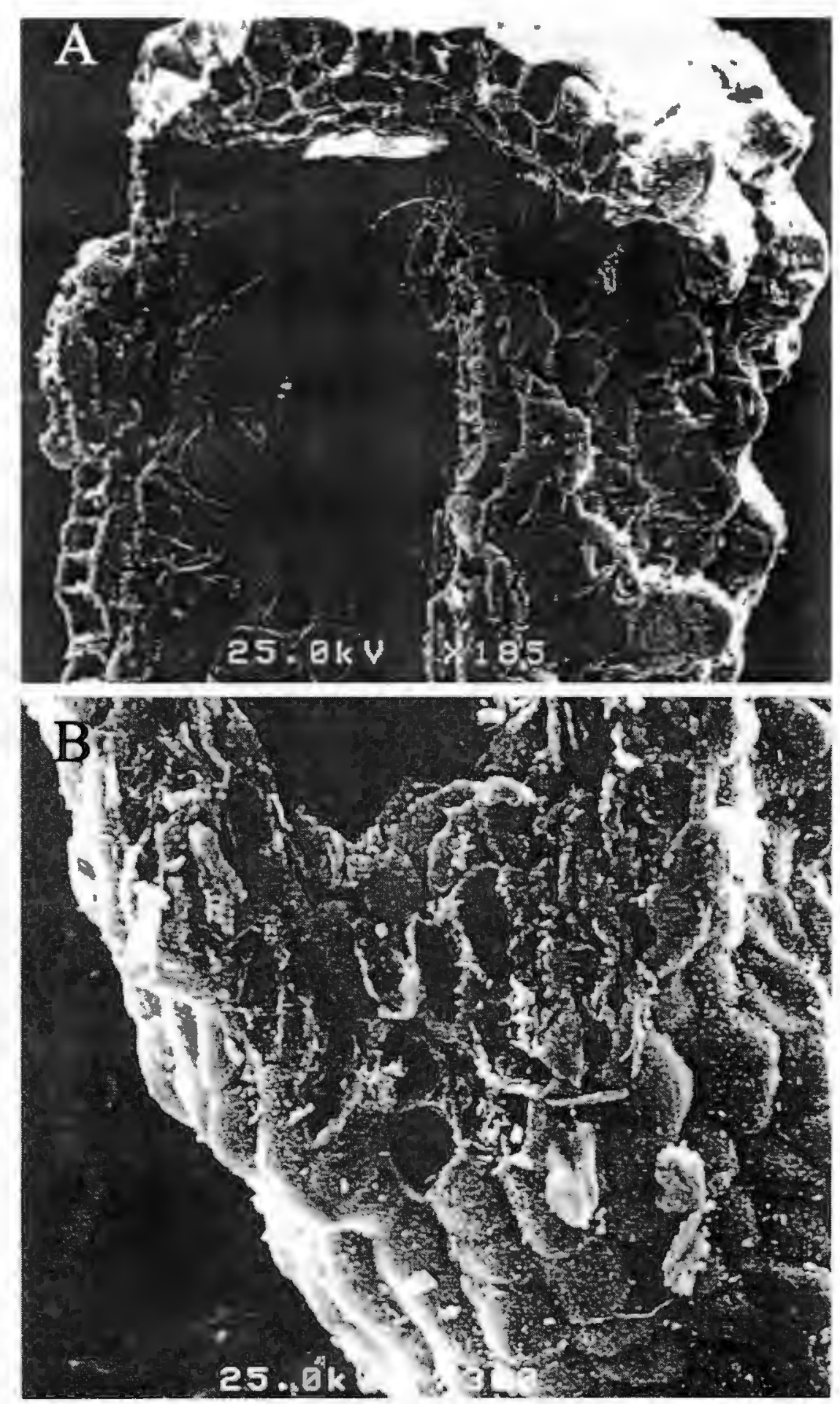
Figure 5. Seed coats of Darlingtonia californica and Sarracenia leucophylla after acid treatments

A - D. californica 4 min. $\mathrm{H}_{2} \mathrm{SO}_{4}(\mathrm{X} 58)$

B - D. californica with seed wall integrity compromised (X140)

C-S. leucophylla 4 min $\mathrm{H}_{2} \mathrm{SO}_{4}(\mathrm{X} 29)$

D - S. leucophylla 4 min $\mathrm{H}_{2} \mathrm{SO}_{4}(\mathrm{X} 520)$

E - S. leucophylla 8 min $\mathrm{H}_{2} \mathrm{SO}_{4}(\mathrm{X} 40)$

F - S. leucophylla 8 min $\mathrm{H}_{2} \mathrm{SO}_{4}$ (X175 (cracks in seed coat occurred during SEM observation)

G - S. leucophylla 16 min $\mathrm{H}_{2} \mathrm{SO}_{4}(\mathrm{X} 26)$

H - S. leucophylla $16 \mathrm{~min} \mathrm{H}_{2} \mathrm{SO}_{4}(\mathrm{X} 290)$ 

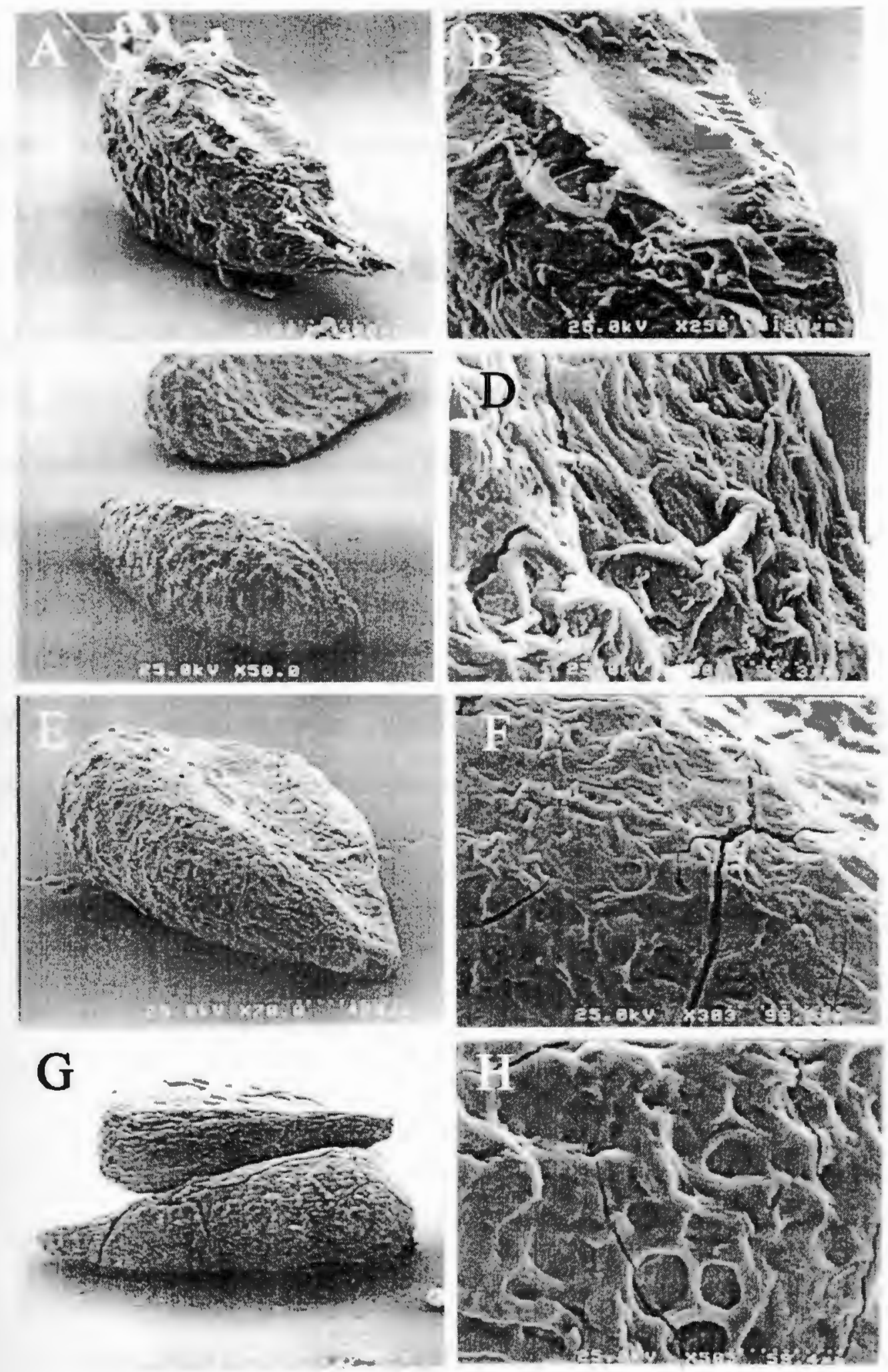
Figure 6. Seed surface topology of several Sarracenia species

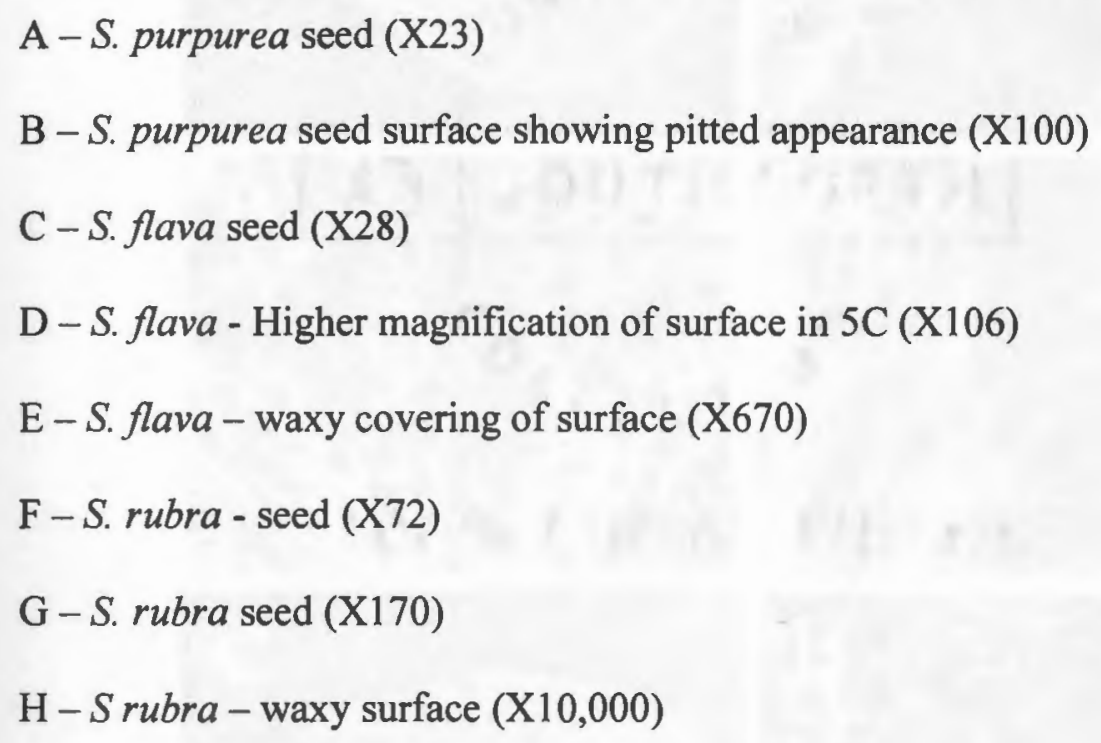



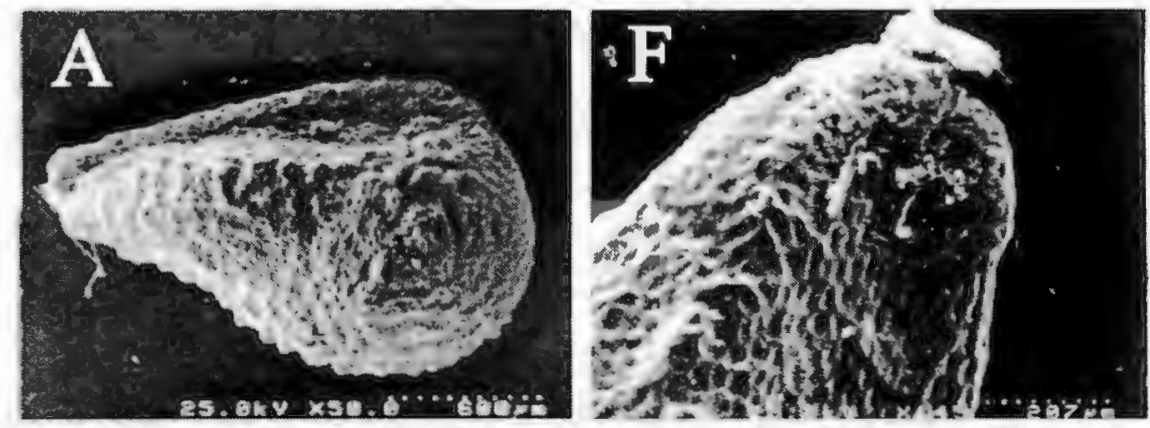

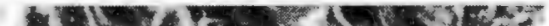

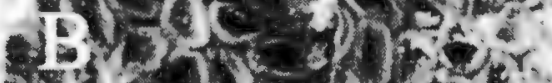

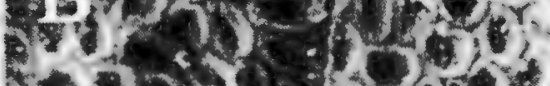

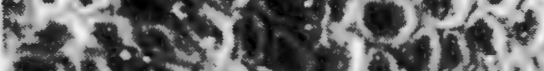

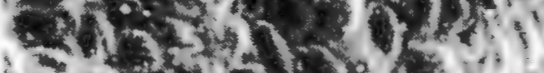

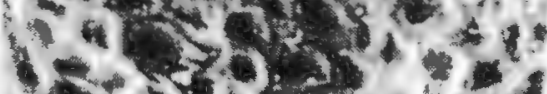

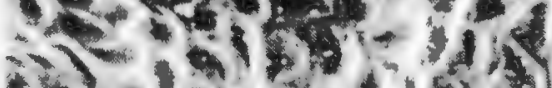

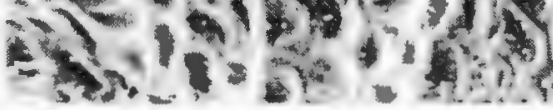
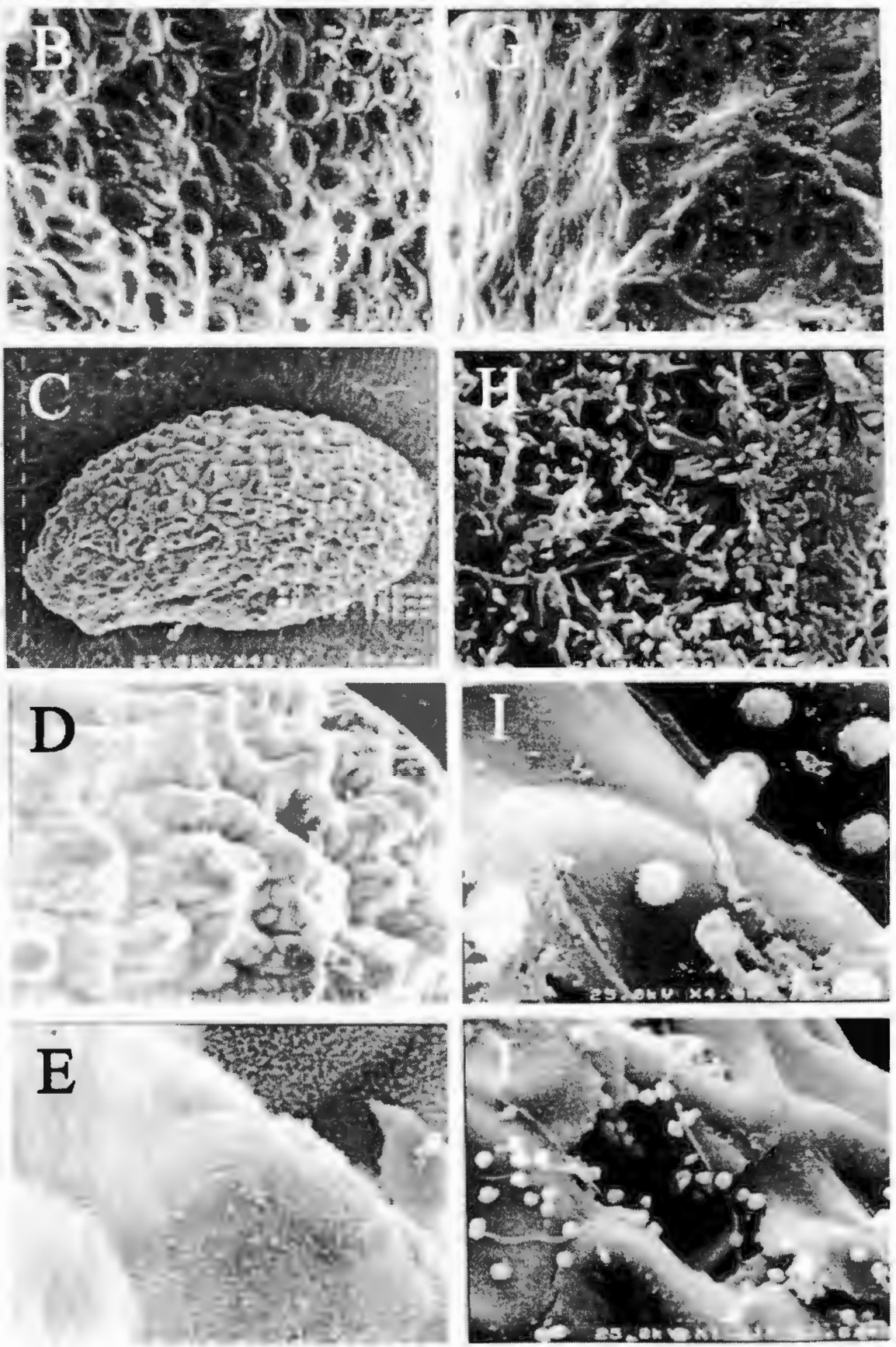
Figure 7. Seed surface morphology of several species of Drosera
A - D. tracyi - collapsed surface cells (X64)
B - D. tracyi - enlarged view of $1 \mathrm{~A}(\mathrm{X} 590)$
C - Seed of $D$. intermedia (X78)
$\mathrm{D}-D$. intermedia - waxy covering of surface projections (X860)
E - D. spathulata seed (X40)
F - D. spathulata seed surface (X190)
$\mathrm{G}-$ D. spathulata $(\mathrm{X} 1150)$
$\mathrm{H}-$ D. auriculata seed (X40)
I - D. auriculata seed surface (X400)
$\mathrm{J}-$ D. binata seed (X57) 

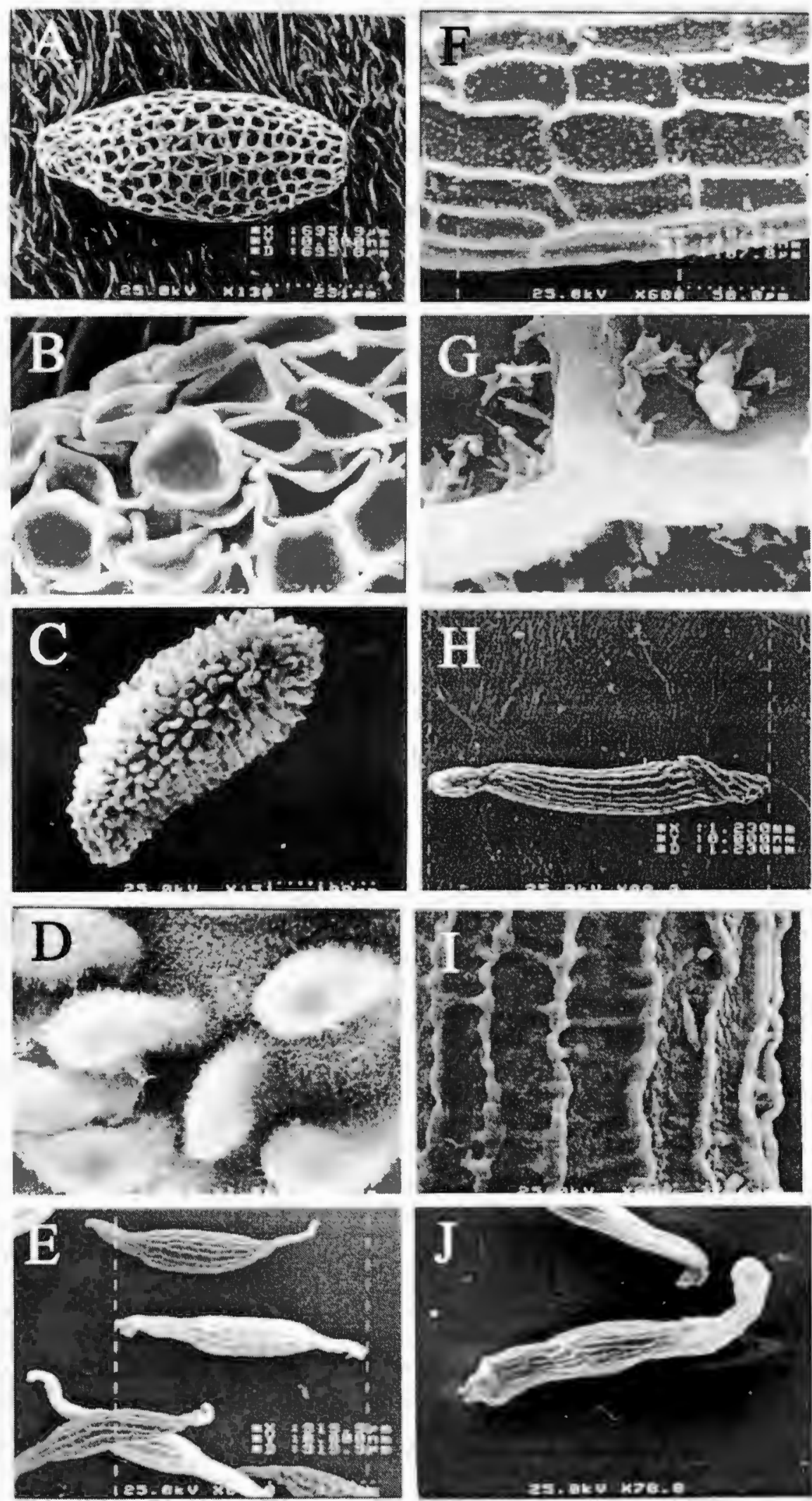
Figure 8. SEM study of seed surface topography and internal structure of seed coat of Dionaea muscipula (Venus Fly Trap)

A - Seed coat showing relatively smooth surface (X 150)

B - "Cobblestone" appearance of bulging periclinal walls (X320)

C - Hollow, heavily sclerified cells of outer coat (X280)

D - Thickened anticlinal walls of sclerified cells (X740)

E - Fungal hyphae with sporangia emerging from micropylar pole of a seed (X120)

F - Thickened, homogeneous extracellular matrix (X3400)

$\mathrm{G}$ - Fungal sporangium (X630)

$\mathrm{H}$ - Fungal sporangium (X2800)

I - Honeycomb appearance of outer wall (X36)

$\mathrm{J}$ - Higher magnification of sporangium in figure $7 \mathrm{E}(\mathrm{X} 4100)$ 

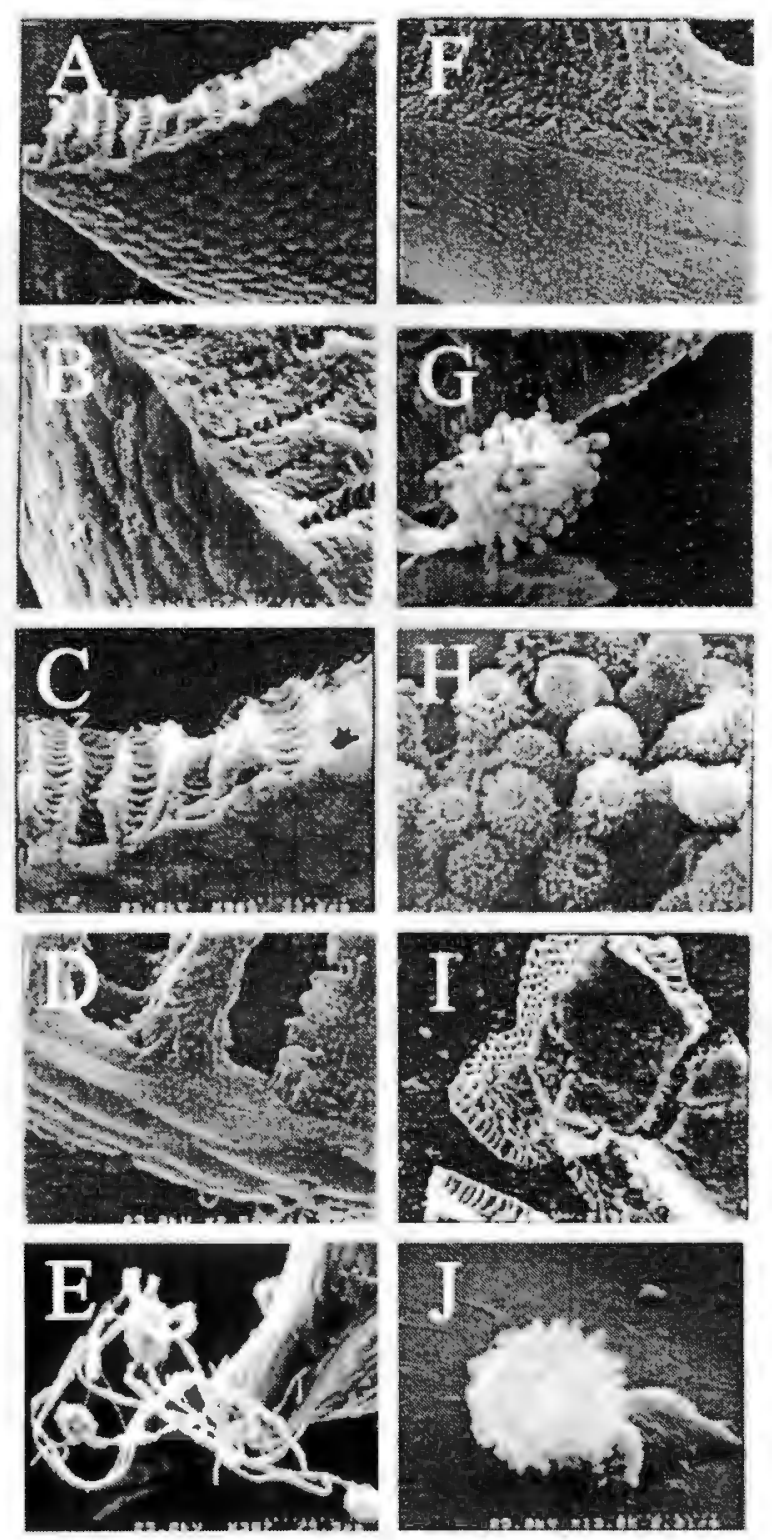


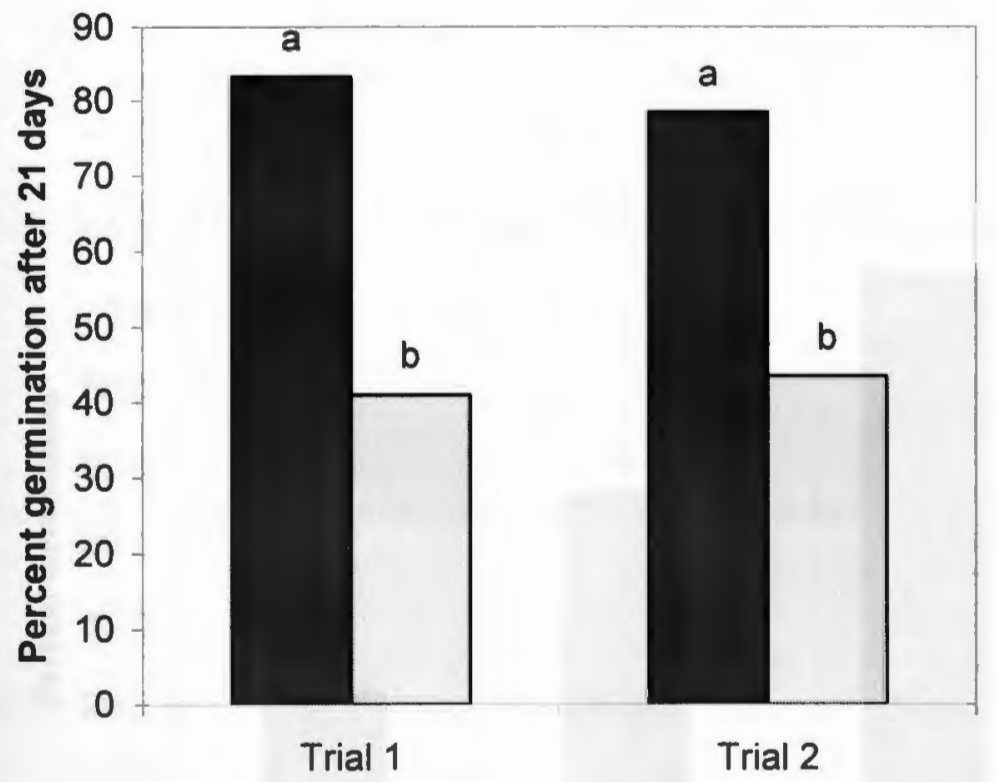

Figure 9. Comparison of percent germination of seeds of $D$. californica in $\mathrm{H}_{2} \mathrm{O}$ (black) and liquid $1 / 2$ strength MS medium (gray) in two trials. Columns denoted by different letters are significantly different. $\mathrm{P}=0.006$ and $\mathrm{P}=0.004$ in the two trials respectively. 


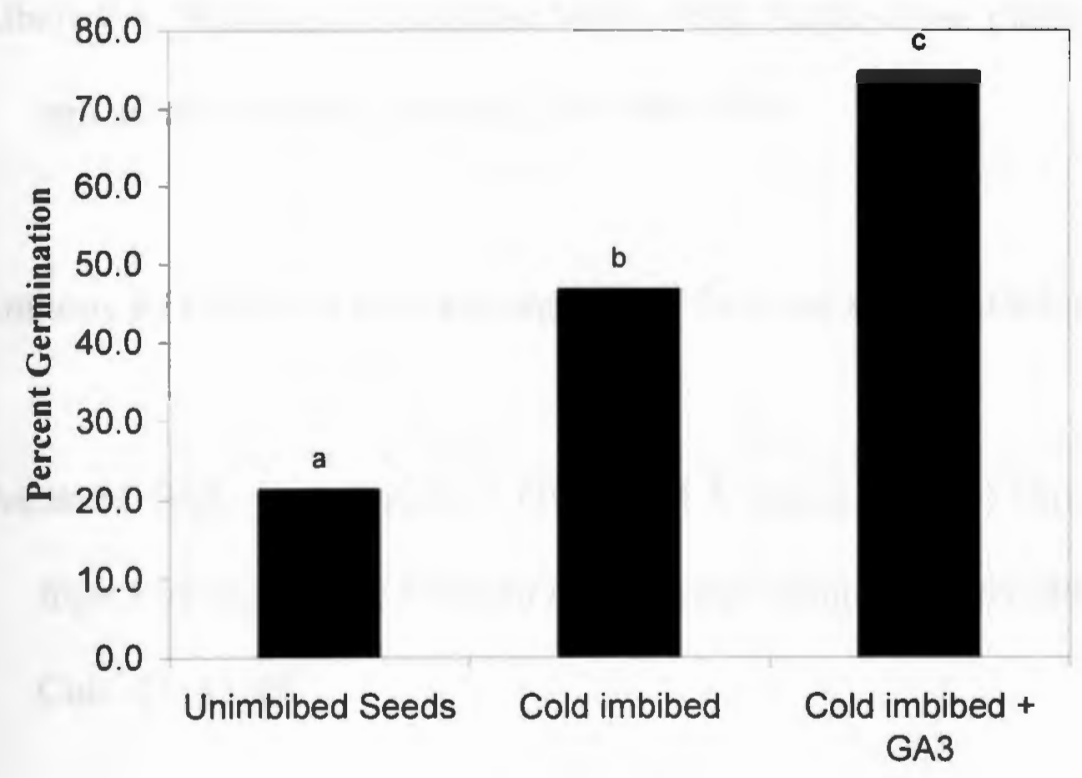

Figure 10. Effect of three different pre-germinative treatments on percent germination of seeds of $D$. californica after 21 days of incubation. Columns denoted by different letters are significantly different (Fisher's PLSD; $\mathrm{P}=<0.05$ ). This experiment was repeated twice with similar results. 


\section{Literature Cited}

Adamec L (1997) Mineral Nutrition of Carnivorous Plants: A Review. Bot. Rev. 63: 273-299

Albert VA, Williams SE \& Chase MW (1992). Carnivorous plants: phylogeny and structural evolution. Science 257: 1491-1495

Anthony LJ (1992) In vitro propagation of Drosera spp. HortScience 27: 850

Bobak M, Blehova A, Kristin J, Ovecka M \& Samaj J (1995) Direct plant regeneration from leaf explants of Drosera rotundifolia cultured in vitro. Plant Cell Tiss. Org. Cult. 43: 43-49

Bobak M, Blehova A, Samaj J \& Ovecka M (1993) Studies of organogenesis from the callus culture of the sundew (Drosera spathulata Labill.). Plant Phys. 142: 251253

Boulay J (1995a) Les plantes carnivores, essais de micropropagation. Bull. Acad. Soc. Lorraines Sci. 34: 151-159

Budzianowski J (2000) Naphthoquinone glucosides of Drosera gigantea from in vitro cultures. Plant. Med. 66: 667-669 
Budzianowski J (1996) Naphthohydroquinone glucosides of Drosera rotundifolia and D. intermedia from in vitro cultures. Phytochemistry 4: 1145-1147

Budzianowski J (1995b). Naphthoquinones of Drosera spathulata from in vitro cultures. Phytochemistry 40: 1145-1148

Carroll G (1988) Fungal endophytes in stems and leaves: From latent pathogen to mutualistic symbiont. Ecology 69: 2-9

Crouch IJ, Finnie JF \& van Staden J (1990) Studies on the isolation of plumbagin from in vitro and in vivo grown Drosera species. Plant Cell Tiss. Org. Cult. 21: 79-82

D'Amato P (1998) The Savage Garden. Ten Speed Press. Berkeley CA

Ellison AM (2001) Interspecific and intraspecific variation in seed size and germination requirements of Sarracenia (Sarraceniaceae). Am. J. Bot. 88: 429-437

Givnish TJ, (1989) Ecology and evolution of carnivorous plants. Plant-Animal Interactions (pp. 243-290) McGraw-Hill, Inc. New York

Godt MJW \& Hamrick JL, (1996) Genetic structure of two endangered pitcher plants, Sarracenia jonseii and S. oreophila (Sarraceniaceae). Am. J. Bot. 83: 1016-1023 
Godt MJW \& Hamrick JL, (1998) Allozyme diversity in the endangered pitcher plant Sarracenia rubra ssp. alabamensis (Sarraceniaceae) and its close relative $S$. rubra ssp. rubra. Am. J. Bot. 85 (6): 802-810

Gotsch SG \& Ellison AM (1998) Seed germination of the northern pitcher plant, Sarracenia purpurea. Northeast. Nat. 5:175-182

Hinton DM and Bacon CW (1984) The distribution and ultrastructure of the endophyte of toxic tall fescue. Can. J. Bot. 63: 36-42

Hook ILI (2001) Naphthoquinone contents of in vitro cultured plants and cell suspensions of Dionaea muscipula and Drosera species. Plant Cell Tiss. Org. Cult. 67: $281-285$

Koske RE (1977) Spiral growth of Phycomyces: some new observations in the Northern and Southern hemispheres. Mycologia 69: 189-193

Lecoufle M (1990) Carnivorous Plants: Care and Cultivation. Cassell Publishers Ltd. London, UK

Lichtscheidl IK, Lancelle SA \& Hepler PK, (1990) Actin-endoplasmic reticulum complexes in Drosera. Protoplasma 155: 116-126 
Lloyd EF (1942) The Carnivorous Plants. Chronica Botanica Co. Waltham, MA

Mandossian AJ, (1966) Germination of seeds in Sarracenia purpurea (pitcher plant). Mich. Bot. 5: 67-69

Miles DH, Kokpol U, Zalkow LH, Steindel SJ \& Nabors, JB (1974) Preliminary investigation of antitumor activity of Sarracenia flava. J. Pharm. Sci. 63: 613

Minocha SC (1985) In vitro propagation of Dionaea muscipula. HortScience 20: 216217

Murashige T \& Skoog F (1962) A revised medium for rapid growth and bioassays with tobacco tissue culture. Physiol. Plant. 15: 473-497

Perica MC \& Berljak J (1996) In vitro growth and regeneration of Drosera spathulata Labill. on various media. HortScience 31: 1033-1034

Pietropaolo J \& Pietropaolo P (1986) Carnivorous Plants of the World. (pp. 25-73) Timber Press, Portland, Oregon 
Samaj J, Bobak M, Blehova A, Kristin J \& Auxtova-Samajova O (1995)

Developmental SEM observations on an extracellular matrix in embryogenic calli of Drosera rotundifolia and Zea mays. Protoplasma 186: 45-49

Schefler WC (1979) Statistics for the Biological Sciences. Second Edition. AddisonWesley Publishing Company. Reading MA

Schnell DE (2002) Carnivorous Plants of the United States and Canada. Second Edition. Timber Press. Portland, Oregon Pgs. 229-242

Slack A (2000) Carnivorous Plants. MIT Press. Cambridge MA

Vidaver W (1977) Light and seed germination. In: The Physiology and Biochemistry of Seed Dormancy and Germination. Khan AA (ed) North Holland Publishing Company, Amsterdam

White JF, Jr., Anthony GE \& Chandler KF (1993) Endophyte-host associations in grasses. XVIII. Moisture relations and insect herbivory of the emergent stromal leaf of Epichloe. Mycologia 85: 195-202 
White JF \& Cole GT (1986) Endophyte-host associations in forage grasses. IV. The endophyte of Festuca versuta. Mycologia 78: 102-107

Withner CL (1964) Notes on the cultivation of insectivorous plants in vitro. Bull. Torr. Bot. Club 91: 412-413

Zenk MH, Furbringer M \& Steglich W (1969) Occurrence and distribution of 7methyljuglone and plumbagin in the Droseraceae. Phytochemistry 8: 2199-2200 


\title{
ESTABLISHMENT OF A MICROPROPAGATION SYSTEM FOR MEMBERS \\ OF THE SARRACENIACEAE
}

II.

\author{
IN VITRO GROWTH AND EARLY SEEDLING DEVELOPMENT \\ OF THE NORTH AMERICAN PITCHER PLANT \\ DARLINGTONIA CALIFORNICA TORREY
}

\begin{abstract}
A simple effective system for in vitro growth, multiplication and rooting of axenically germinated seedlings of $D$. californica has been developed. Seedlings grown on solid $1 / 2$ strength Murashige and Skoog medium produced more biomass and more and longer pitcher leaves than seedlings grown on other solid media assayed. Root development on all solid media was minimal and usually limited to the seminal root. Seeds stimulated by gibberellic acid prior to germination and exposed to auxin and cytokinin during early seedling development produced multiple offshoots as well as fibrous root systems when transferred to $1 / 2$ strength liquid medium containing charcoal. Similarly treated seedlings transferred to $1 / 2$ strength liquid media without charcoal produced multiple offshoots but fewer roots. Seedlings cultured in medium without charcoal produced more but smaller pitchers than seedlings cultured in medium containing charcoal. Multiplication did not occur on solid media, and seedling growth was stunted. Seedling multiplication through offshoots occurred in all liquid media and was both prolific and rapid.
\end{abstract}




\section{INTRODUCTION}

Manuscript 1 (this dissertation) reported techniques for the effective surface sterilization and subsequent axenic germination of seeds of Darlingtonia californica. This manuscript reports on the selection of a suitable growth and rooting medium for in vitro germinated seedlings that also allows the induction of clonal multiplication. Growth and rooting were investigated using both solid and liquid media.

Darlingtonia californica is a North American pitcher plant naturally occurring in Oregon and California (Schnell, 2002). It is interesting as a study organism not only because of its carnivorous habit but also because it offers the opportunity to study a combination of unique developmental and physiological events. For instance, $D$. californica usually grows beside cold (below $20^{\circ} \mathrm{C}$ ) running streams in serpentine soils containing levels of nickel, zinc, chromium and other metals that are phytotoxic to many plant species (Schnell, 2002). However, it accumulates only low levels of these metals (Reeves et al., 1983). Additionally, it forms two morphologically and anatomically different pitcher types from the same meristem during the course of its development (Frank, 1975). Such a developmental switch offers the opportunity for investigations at both the cytological and genetic levels. Future research utilizing $D$. californica as a study organism will require the availability of sufficient amounts of plant material. This may be difficult because commercially produced adult or juvenile plants are seldom easy to obtain. Successful in vivo greenhouse cultivation has been limited to a few private collections (Schnell, 2002). 
Although $D$. californica has been the subject of several histological and developmental investigations for over a century (see Lloyd, 1942 for early references) little work has been done on its culture in vitro. Withner (1964) reported a short series of qualitative observations on the application of orchid tissue culture techniques to carnivorous plants. However, he reported the failure of $D$. californica to form roots in vitro after two trials. Also, D. californica has been included as part of a broad feasibility survey on the micropropagation of several carnivorous plant genera (Boulay, 1995). Although Boulay (1995) reported that few roots were formed in vitro, results were not reported quantitatively.

This manuscript reports on the establishment of a system for in vitro culture of D. californica that provides a continuing source of explant material for subculture and future experimentation. 


\section{MATERIALS AND METHODS}

\section{Plant Material}

For growth studies on solid media, seeds of $D$. californica were surface disinfested and germinated using Method \# 2, Manuscript 1 (this dissertation). For growth studies in liquid media, seeds of $D$. californica were imbibed at $4-7^{\circ} \mathrm{C}$ in $10 \mathrm{ml}$ of sterile deionized $\mathrm{H}_{2} \mathrm{O}$ (pH 5.0) with one drop of Tween 20. After 24 h the $\mathrm{H}_{2} \mathrm{O}$ was replaced with $10 \mathrm{ml}$ of an aqueous solution of $\mathrm{GA}_{3}(6 \mathrm{mg} / \mathrm{l})$, and imbibition was continued for 12 days at $4-7^{\circ} \mathrm{C}$. Seeds were then surface disinfested in $3 \% \mathrm{H}_{2} \mathrm{O}_{2}$ (drugstore-variety, CVS®) with one drop of Tween 20 for $12 \mathrm{~min}$, transferred (without rinsing) to two $250 \mathrm{ml}$ Erlenmeyer flasks containing $75 \mathrm{ml}$ of Phytomax Orchid Multiplication Medium (POMM; see Table 1 for medium components;pH 5.0). Flasks were incubated in a growth chamber at $27^{\circ} \mathrm{C} \pm 2^{\circ}$ with $16-\mathrm{hr} \mathrm{d}^{-1}$ illumination at $170 \mu \mathrm{mol} \mathrm{m} \mathrm{sec}^{-1}$.

\section{Growth Studies on Solid Media}

Three basal media were used: MS (Murashige and Skoog, 1962) at $1 / 2$ strength salts, Burgeff's $\mathrm{N}_{3} f$ (Arditti, 1982), and a modified, sphagnum-based medium (Withner, 1964). Media components are listed in Table \#1. MS medium was purchased pre-mixed from Sigma. Burgeff's $\mathrm{N}_{3}$ f medium and sphagnum- based medium were prepared in the laboratory. For sphagnum based-medium, freshly collected live, unwashed, green sphagnum was cleaned of leaf litter and other debris then compacted in a $500 \mathrm{ml}$ beaker. The compacted moss was transferred to a household blender and finely blended for $3 \mathrm{~min}$ in $500-700 \mathrm{ml}$ of deionized water. Salts and organics were added before bringing the sphagnum solution to volume (1000 
$\mathrm{ml}$ ). All media contained $20 \mathrm{~g} / \mathrm{l}$ sucrose as the carbon source and $1 \mathrm{ml}$ of MS vitamin solution (1000X, Sigma). The $\mathrm{pH}$ of all media was adjusted to 5.0 with $\mathrm{KOH}$ or $\mathrm{HCl}$ prior to the addition of agar. Agar was melted by heating the solution on a hot plate with constant stirring, poured into a graduated dispensing column and aliquots of 15 $\mathrm{ml}$ were dispensed into $125 \mathrm{~mm} \times 25 \mathrm{~mm}$ test tubes. Tubes were capped with translucent plastic closures and autoclaved $\left(121^{\circ} \mathrm{C}\right.$ for $\left.15 \mathrm{~min}\right)$.

In a laminar-flow hood, 2-3 week old seedlings were transferred, individually, to tubes of medium (18 tubes per treatment). Tubes were sealed with Parafilm and placed in a growth chamber with temperature and light conditions as previously described. After 12 weeks of culture the plants were harvested and data collected. The parameters examined were the number of pitcher leaves per seedling (pitchers less than $3 \mathrm{~mm}$ in length were not scored), length of pitcher leaves (measured to the nearest $\mathrm{mm}$ ), and total dry weight of explants per treatment. For dry weights, plants were dried at $60^{\circ} \mathrm{C}$ for two days and then weighed. Qualitative observations regarding color and general vigor were recorded. Experiments were repeated twice.

\section{Growth and rooting in liquid media}

Triplicate $250 \mathrm{ml}$ Erlenmeyer flasks containing $75 \mathrm{ml}$ of 1) $1 / 2$ strength MS, 2) 1/2 strength MS with $2 \mathrm{~g} / \mathrm{l}$ activated charcoal (Sigma, St. Louis, MO), 3) 1/4 strength MS or 4) $1 / 4$ strength MS with $2 \mathrm{~g} / \mathrm{l}$ activated charcoal were each inoculated with 5 seedlings with offshoots (9-12 pitcher leaves) that had been grown on solid POMM for 2 months. All media were adjusted to $\mathrm{pH} 5.0$ prior to autoclaving.. Concentrations of sucrose and vitamins were as described for solid media. Flasks were transferred to a 
growth chamber with light and temp conditions as described above. After $61 / 2$ weeks of culture, plants were harvested and data collected.

\section{Statistical Analyses}

\section{Growth on Solid Media}

Comparisons of numbers of pitchers produced per seedling between different media formulations were made using ANOVA followed by Fishers Post Hoc test. For comparison of pitcher length, average pitcher lengths per replicate were log transformed then analyzed as described above. Dry masses are reported as percent difference between treatments.

\section{Rooting and Growth in Liquid Media}

To determine average pitcher lengths, the longest 25 pitchers in each flask were measured to the nearest $\mathrm{mm}$, and average pitcher length per flask was calculated. In assessing the total number of pitchers per flask, only pitchers longer than $2 \mathrm{~cm}$ were measured. Vitrified or etiolated pitchers were not scored. Total number of roots per flask was determined by scoring the number of roots observed on 17 separate clusters of pitchers (each cluster arising from a single rhizome). Dry weight of total plant material from each flask was obtained as described previously. Differences among treatments were analyzed with ANOVA and Fisher's Post Hoc test. 


\section{RESULTS}

\section{Growth on Solid Media}

Seedlings grown on solid $1 / 2$ strength MS medium produced more pitchers than those grown on either Burgeff's $\mathrm{N}_{3}$ f medium $(\mathrm{P}=0.002)$, or on sphagnum based medium ( $P=0.002$, Fig. 1). Although growth of seedlings on Burgeff's medium resulted in the least number of pitchers produced, this difference was not significant compared with those grown on sphagnum medium. The average length of pitchers was significantly greater for seedlings grown on MS medium than those grown in sphagnum medium $(\mathrm{P}=0.03)$ but not significantly different from those grown in Burgeff's medium (Fig. 2). Qualitatively, seedlings grown in $1 / 2$ MS medium appeared greener and healthier than those grown in the other media formulations (Fig. 3A).

Seedlings grown in Burgeff's medium (Fig. 3B) began to exhibit a yellow appearance soon after transfer from $\mathrm{H}_{2} \mathrm{O}$ agar. Several began to brown by the end of the experiment, and growth appeared to be arrested. In contrast to seedling growth on both $1 / 2$ MS and Burgeff's, seedlings grown in sphagnum-based medium (Fig. 3C) occupied an intermediate position and seedling color ranged from green to yellow green. Except for the seminal root, roots were not observed in any of the media tested. In general, growth was slow on all three media. Averages of two trials for the collective dry weights of all seedlings in a treatment were $0.057 \mathrm{~g}(1 / 2 \mathrm{MS}), 0.020 \mathrm{~g}$ (Burgeff's) and $0.019 \mathrm{~g}$ (sphagnum).

\section{Rooting and Growth in Liquid Media}

Production of new pitchers was both rapid and prolific in all liquid formulations tested (Fig. 4). Clusters of pitchers could be separated (Fig. 5A) and 
were observed to originate from a single central rhizome. The large number of pitchers produced in liquid culture was in stark contrast to that produced from the single seedlings grown on solid $1 / 2$ strength MS medium for six months (Fig. 5B). The number of pitchers was significantly greater without charcoal in either $1 / 2$ strength or $1 / 4$ strength liquid MS medium $(\mathrm{P}<0.02)$, but was not affected by medium strength in the presence or absence of charcoal ( $\mathrm{P}>0.93$, Fig. 6). In contrast, pitcher length was significantly greater with charcoal in either $1 / 2$ and $1 / 4$ strength MS $(P<0.0001$, Fig. 7). Pitchers produced in medium containing charcoal were brighter green and appeared to be more robust due to an observed (but not quantified) difference in diameter. Root production was greater in $1 / 2$ strength medium with charcoal than in any other treatment $(\mathrm{P}=0.0001$, Fig. 8$)$. However, significantly more roots were produced in $1 / 2$ strength MS without charcoal than in $1 / 4$ MS with or without charcoal $(\mathrm{P}=0.01$ and $\mathrm{P}=0.005$ ). Roots formed in $1 / 2$ strength MS without charcoal were sometimes very long, but multiple root formation was observed only with charcoal (Figs. 9A-D). Roots were usually absent in $1 / 4$ strength MS without charcoal (Fig. 10a) and were solitary and short when present (Figs.10B and D). Addition of charcoal to $1 / 4$ strength MS produced longer solitary roots (Fig. 10C).

Charcoal did not affect the dry weights of plant tissues produced after $6 \frac{1}{2}$ weeks of growth in $1 / 2$ strength MS medium $(\mathrm{P}=0.95$, Fig. 11$)$. However, both $1 / 2$ strength treatments were significantly different from $1 / 4$ strength MS liquid medium with and without charcoal $(\mathrm{P}<0.04)$. 


\section{DISCUSSION}

The object of this study was to select a suitable medium for in vitro growth and rooting of $D$. californica. The three media assayed were chosen from the literature based on results reported from prior use in related studies. MS medium at $1 / 2$ strength salts was selected because reduced-salt MS medium is commonly employed for in vitro culture of many carnivorous plant species (see Appendix B). Withner (1964) used Burgeff's $\mathrm{N}_{3}$ f medium in his studies on $D$. californica. However, the formulation is not reported and was obtained from Arditti (1982). The components for sphagnumbased medium were based on Withner (1964). Potassium nitrate and myo-inositol concentrations for sphagnum-based medium were based on full strength MS medium (Murashige and Skoog, 1962).

Media were chosen based on preliminary studies (sphagnum-based medium) or results of previous studies (Burgeff's $\mathrm{N}_{3}$ f medium, Withner, 1964). However, the growth of $D$. californica was poor on all solid media tested. Of the media tested, sphagnum-based medium was the least defined. The condition of the sphagnum used in preparation of the medium and the conditions present in the habitat where it was collected, may have affected levels of macro and micronutrients available in the final medium formulation. This may have affected the growth promoting and growth sustaining ability of the medium because certain plants have requirements for specific concentrations of micronutrients (Dodds and Roberts, 1995). Vitamin and sucrose levels were the same in all media. However, nitrogen was supplied as potassium nitrate and casein hydrolysate in sphagnum-based medium, rather than ammonium ion, as in the other media. Growth of plants or plant tissue in culture has been shown 
to be most rapid when both nitrate and ammonium are available (George and Sherrington, 1984). Similarly, the poor growth on solid Burgeff's medium may have resulted from a deficiency in micronutrients, not present in published formulations (Withner, 1964, Arditti, 1982) or media prepared for this study. Withner reported that casein hydrolysate enhanced growth of $D$. californica by $40 \%$ in liquid Burgeff's medium. In the present experiments casein hydrolysate was not added to the formulation.

Growth on solid medium, regardless of the formulation, may have been poor because $D$. californica did not form roots and was therefore unable to absorb enough water or nutrients to allow more vigorous growth. Also, the seminal root may have depleted nutrients in the media surrounding it due to the relatively small volume of media in the tube. In contrast, growth on $1 / 2$ strength MS may have been greater than on the other formulations because of its completeness in terms of macro and micronutrients.

One possibility for the prolific growth of $D$. californica in liquid medium at both $1 / 2$ and $1 / 4$ strength salts may have been the availability of nutrients to the pitcher leaves. Because of its carnivorous habit, internal zones of the pitcher are specialized for absorption of nutrients from digested prey (Lloyd, 1942). In a sense, the liquid medium may have served, literally, as a nutrient soup for the pitcher leaves. Additionally, incubating plant material in liquid-shaken cultures has been shown to increase the rate of shoot proliferation in some species of non-carnivorous plants $(\mathrm{Hu}$ and Wang, 1983). 
Increased pitcher production without charcoal in $1 / 2$ and $1 / 4$ strength MS media may be related to the endogenous production of hormones which stimulate proliferation of $D$. californica in its natural habitat. In media containing charcoal phytohormones may have been adsorbed before they could reach levels that stimulate production of new pitchers. Activated charcoal added to media has been shown to adsorb cytokinin (Takayama and Misawa, 1980). Because the seedlings used to initiate this experiment had been exposed to $\mathrm{GA}_{3}$ and grown on medium containing phytohormones, carry over could have had the ongoing effect of enhancement of pitcher production in charcoal free medium. However, the effect of any carry over of phytohormones to media with charcoal may have been negated due to adsorption of the hormones by the charcoal. In media containing charcoal, pitcher length may have been greater due to adsorption of phytohormones allowing resources to be allocated to the growth of individual pitchers instead of the production of new pitchers.

Increased root production in $1 / 2$ MS with charcoal in comparison to all other treatments, could have been due to greater nutrient availability in the $1 / 2 \mathrm{MS}$. Absorption of nutrients by pitcher leaves of carnivorous plants has been shown to stimulate uptake of nutrients by roots and contribute to greater root length (Adamec, 2002). Additionally, activated charcoal may adsorb toxic substances in the medium resulting in increased root production (Ziv, 1979; Takayama and Misawa, 1980). In the present study, the effect of charcoal on root induction appears to be synergistic with the strength of the medium. Charcoal as an additive for root induction has been used for in vitro rooting of difficult-to-root carnivorous plant species such as 
Nepenthes (Redwood and Bowling, 1990). More work is required in order to clarify the role of charcoal in root induction. 


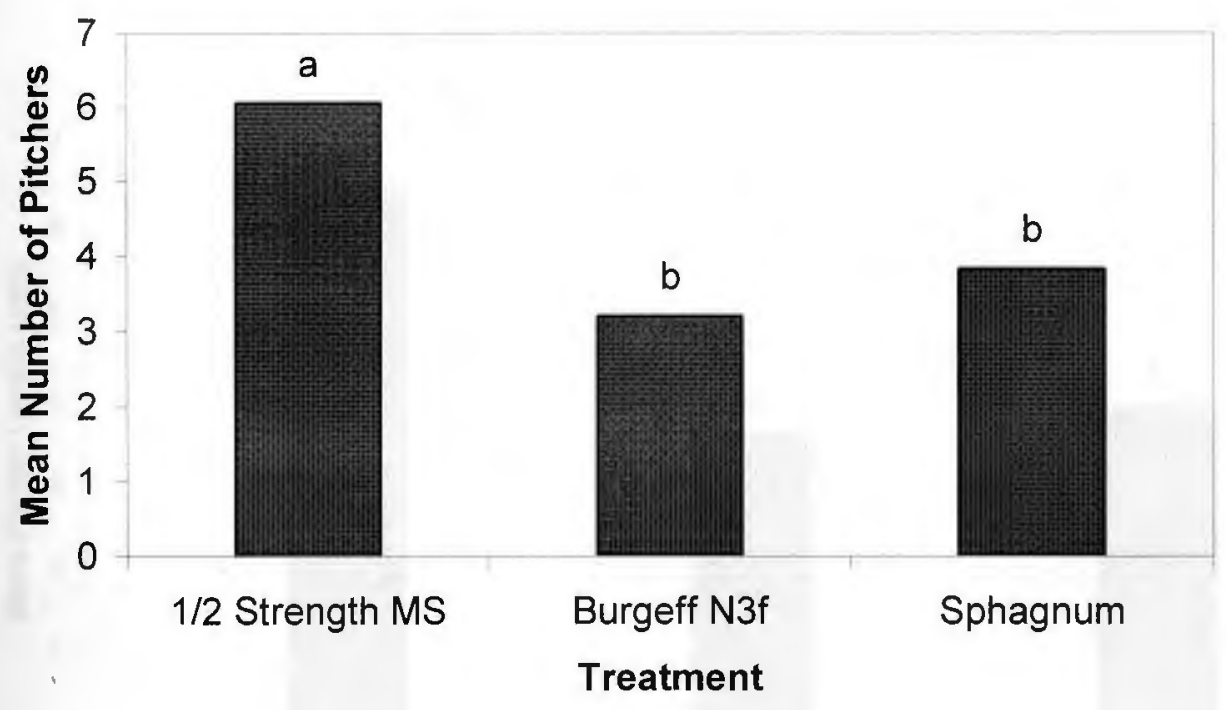

Figure 1. Effect of medium on number of pitchers produced by seedlings of Darlingtonia californica after twelve weeks of growth on three different solid media. Treatments denoted by different letters were significantly different. (Fisher's PLSD; $\mathrm{P}=<0.05$ ). Intra-treatment differences were not significant. 


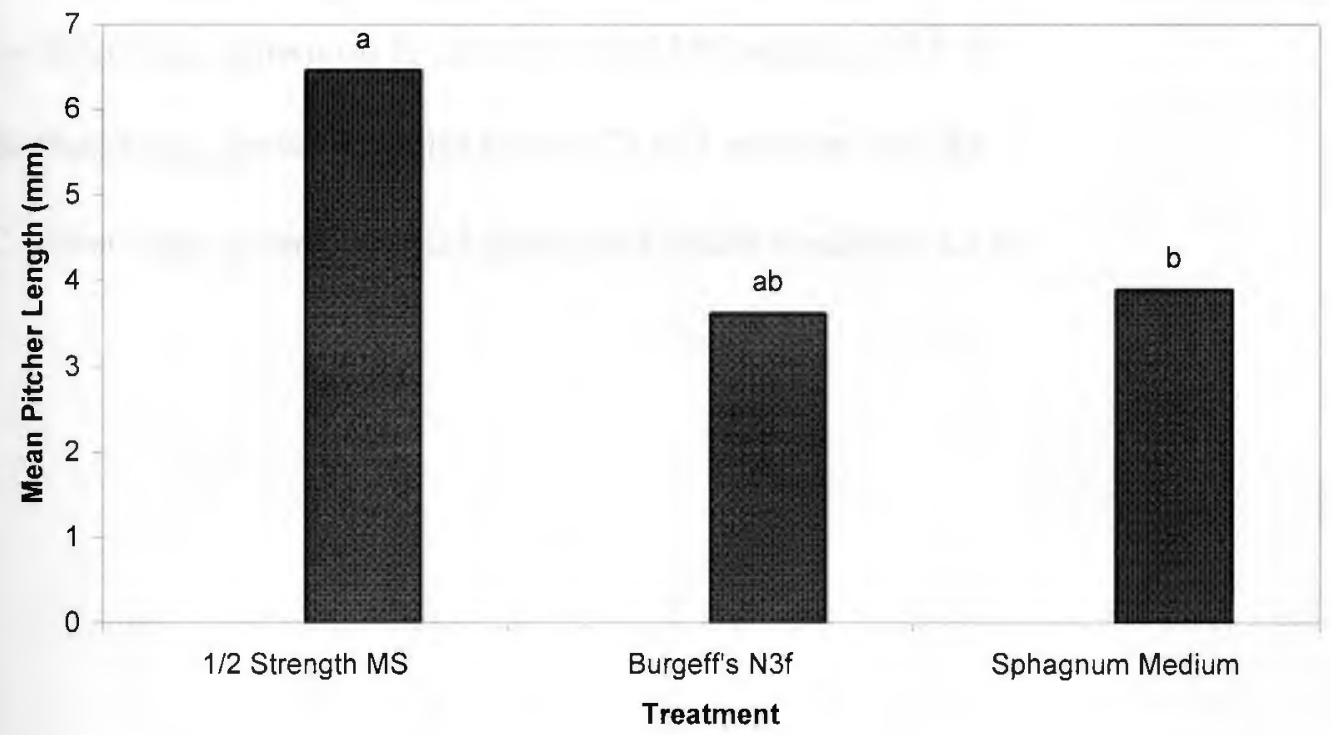

Figure 2. Effect of medium on length of pitchers produced by seedlings of Darlingtonia californica after twelve weeks growth on three different solid media. Treatments denoted by different letters were significantly different. (Fisher's PLSD; $\mathrm{P}=<0.05)$ 
Figure 3. Darlingtonia californica seedlings after 12 weeks of growth

A- Seedlings grown on $1 / 2$ strength solid MS medium (X0.8)

B- Seedlings grown on solid Burgeff's $\mathrm{N}_{3}$ f medium (X0.8)

C- Seedlings grown on solid sphagnum based medium (X0.9) 

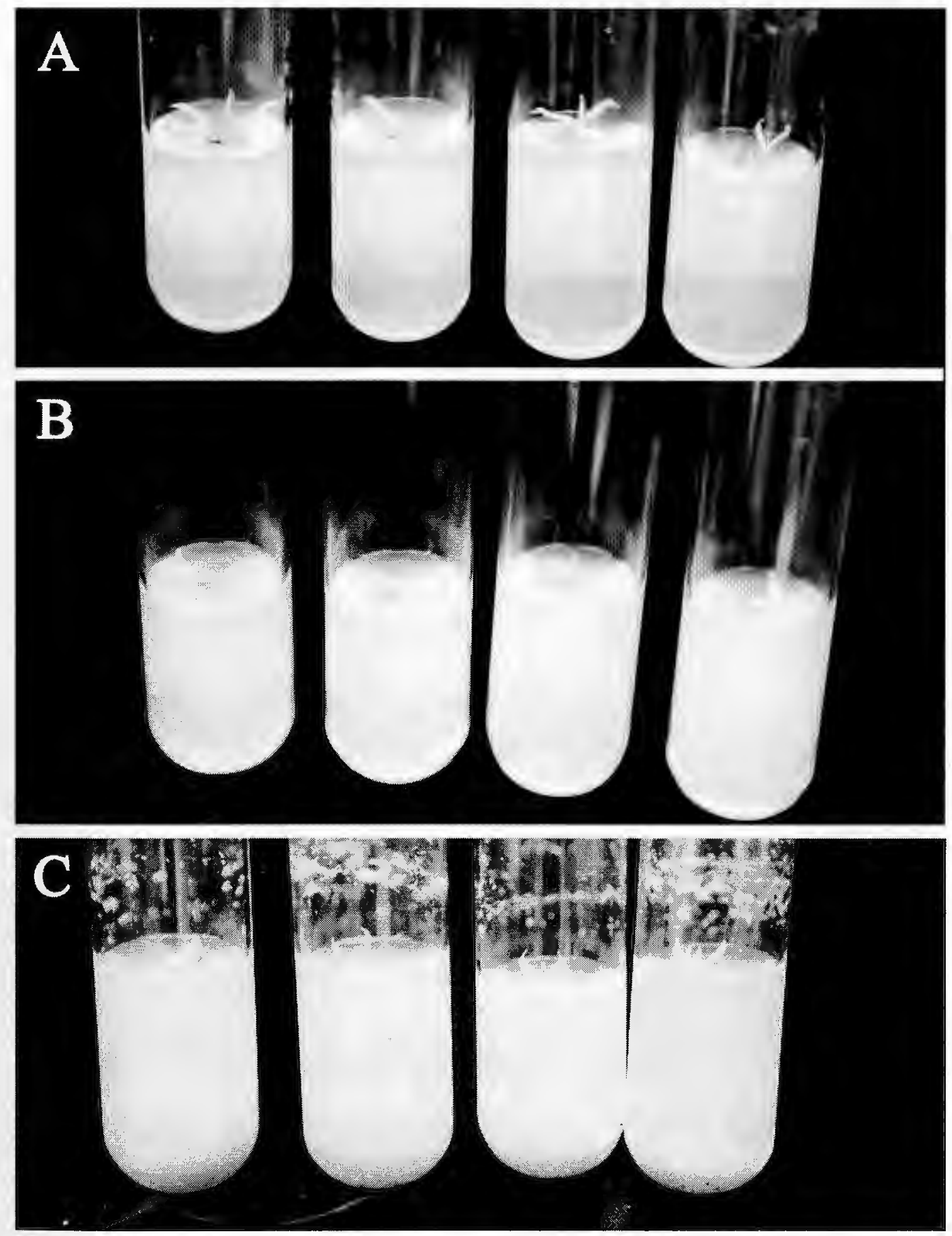
Figure 4. Darlingtonia californica seedlings after $61 / 2$ weeks of growth in liquid media

A - Seedlings grown in liquid $1 / 2$ strength MS medium with charcoal (X0.6)

B - Seedlings grown in liquid $1 / 2$ strength MS medium without charcoal (X0.7)

$\mathrm{C}$ - Seedlings grown in liquid $1 / 4$ strength MS medium with charcoal (X0.6)

$\mathrm{D}$ - Seedlings grown in liquid $1 / 4$ strength MS medium without charcoal (X0.5) 

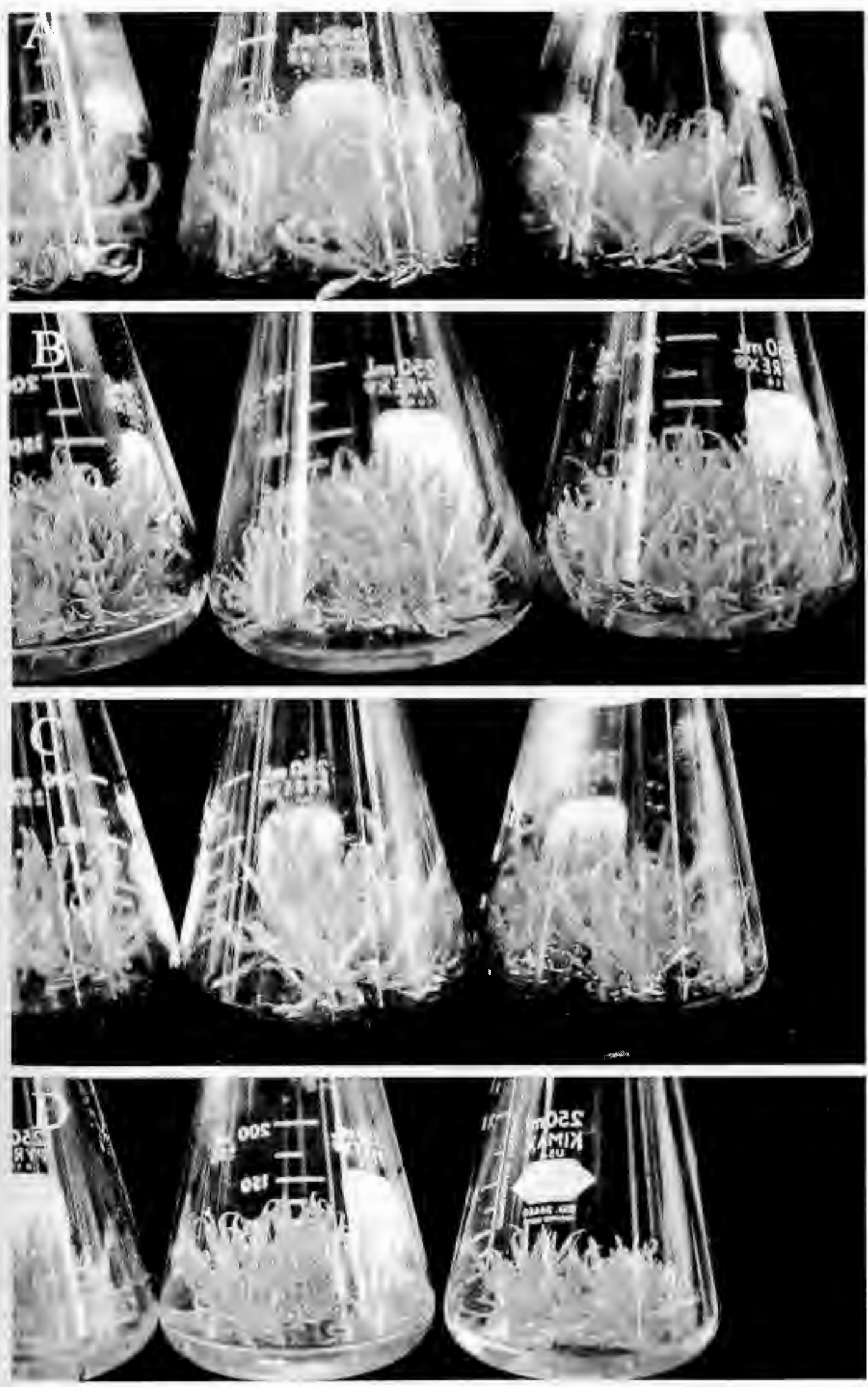
Figure 5. Darlingtonia californica seedlings - proliferation

A - Separation of clumps of pitchers into clusters with each containing a central rhizome after $6 \frac{1}{2}$ weeks of growth in liquid medium (Approximately life size) B - Seedlings grown on $1 / 2$ strength MS solid medium for 5 months without transfer $(\mathrm{X} 0.7)$ 


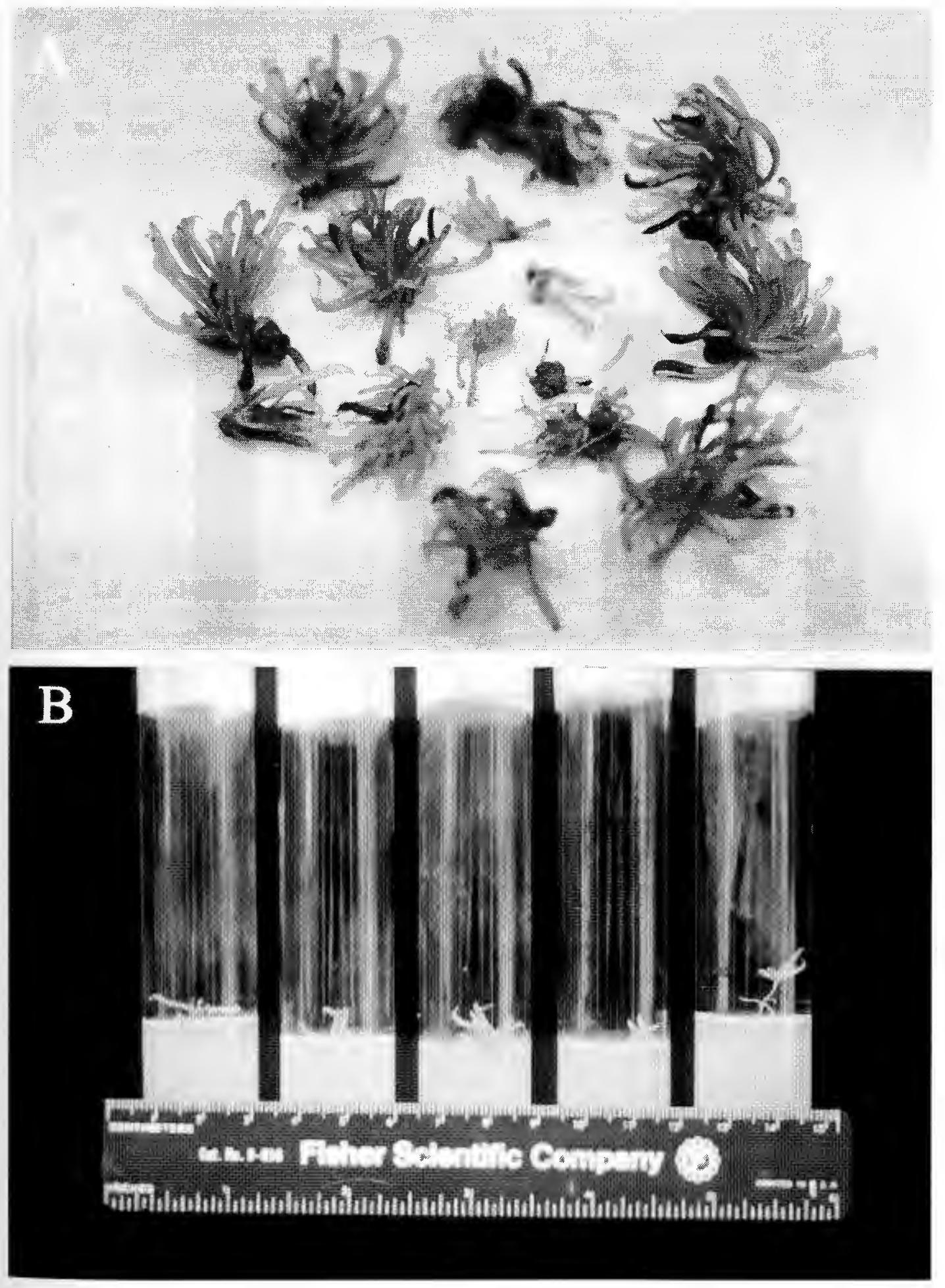




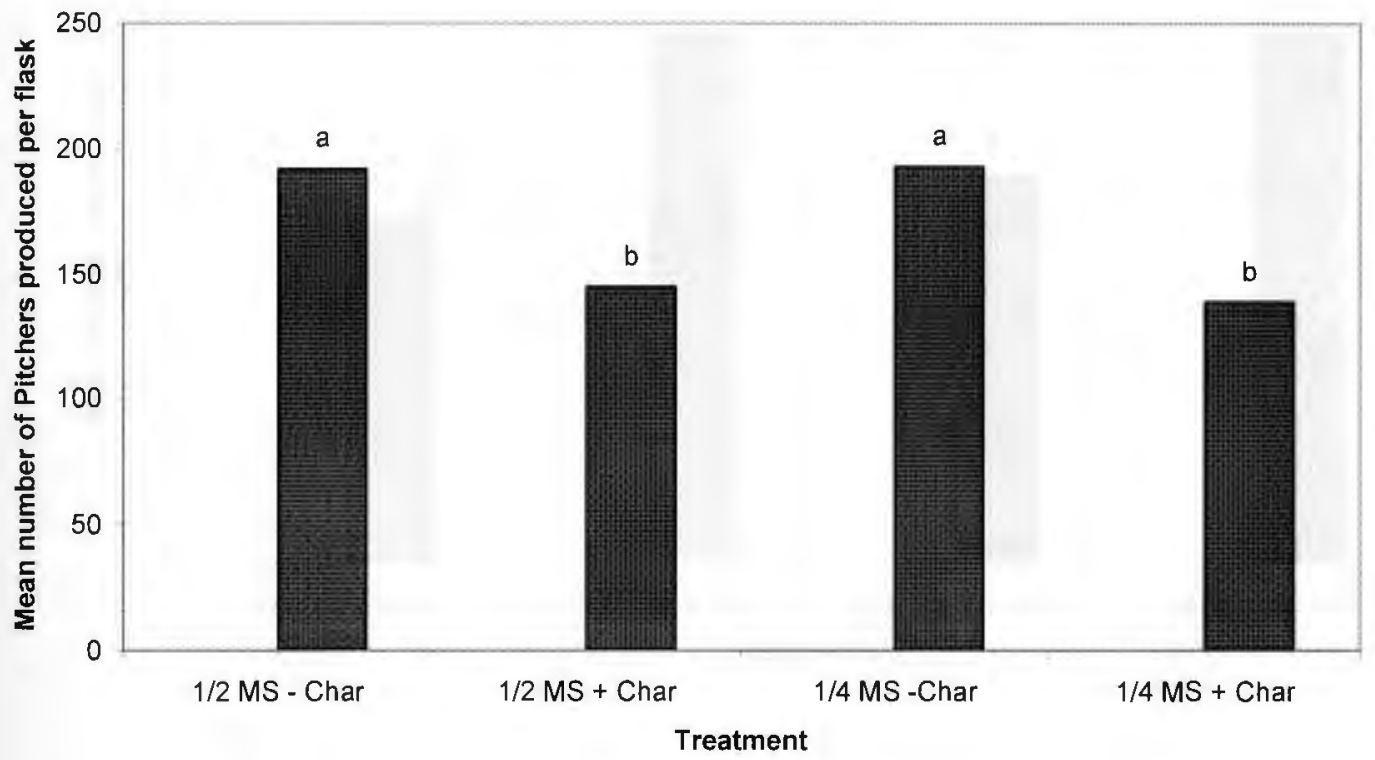

Figure 6. Mean number of pitchers produced per flask per treatment by seedlings of Darlingtonia californica in $1 / 2$ and $1 / 4$ strength liquid MS medium with and without charcoal. Incubation period was $61 / 2$ weeks. Columns denoted by the same letter were not significantly different. (Fisher's PLSD; $\mathrm{P}=0.02$ ) Experiments were repeated twice with similar results. 


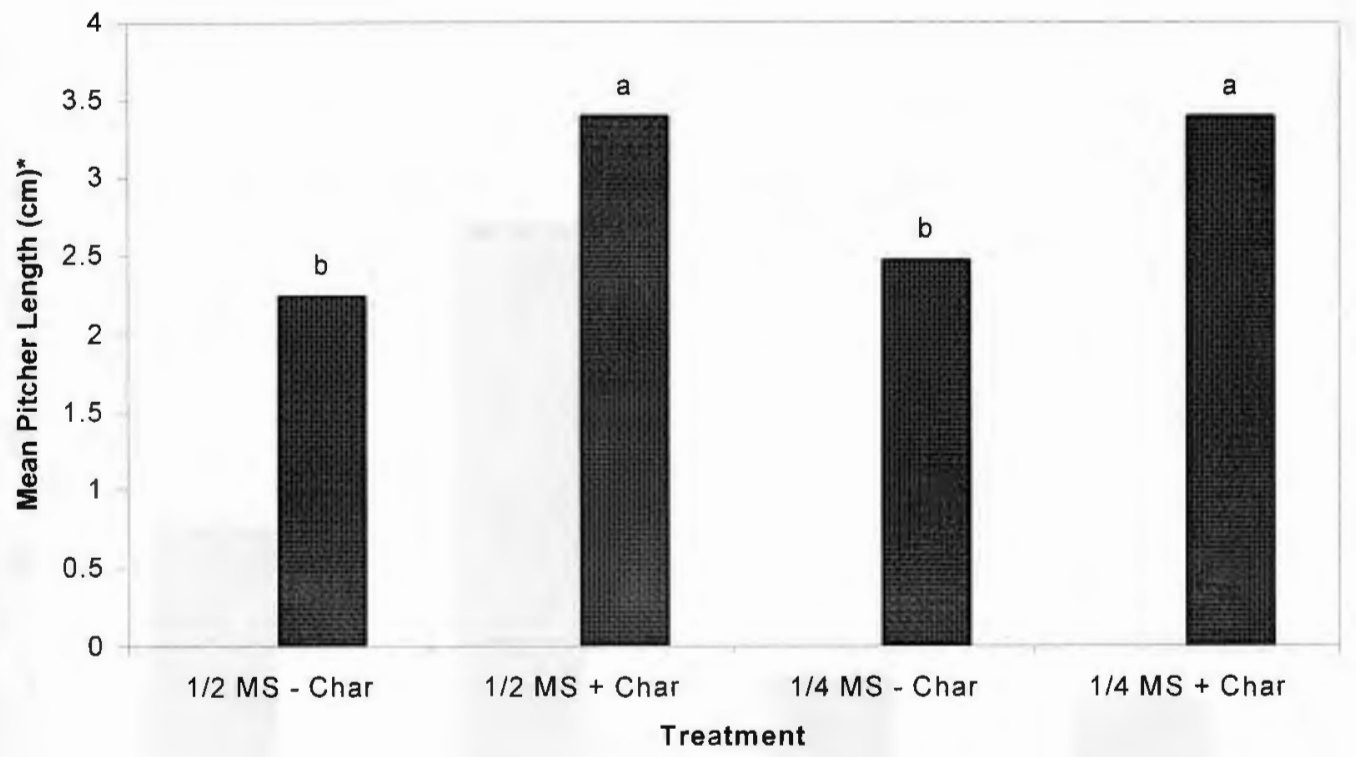

Figure 7. Mean length of pitchers produced per flask per treatment by seedlings of Darlingtonia californica in $1 / 2$ and $1 / 4$ strength liquid MS medium with and without charcoal. Incubation period was $61 / 2$ weeks. Columns denoted by the same letter were not significantly different. (Fisher's PLSD; $\mathrm{P}=<0.0001$ ) Experiments were repeated twice with similar results. 


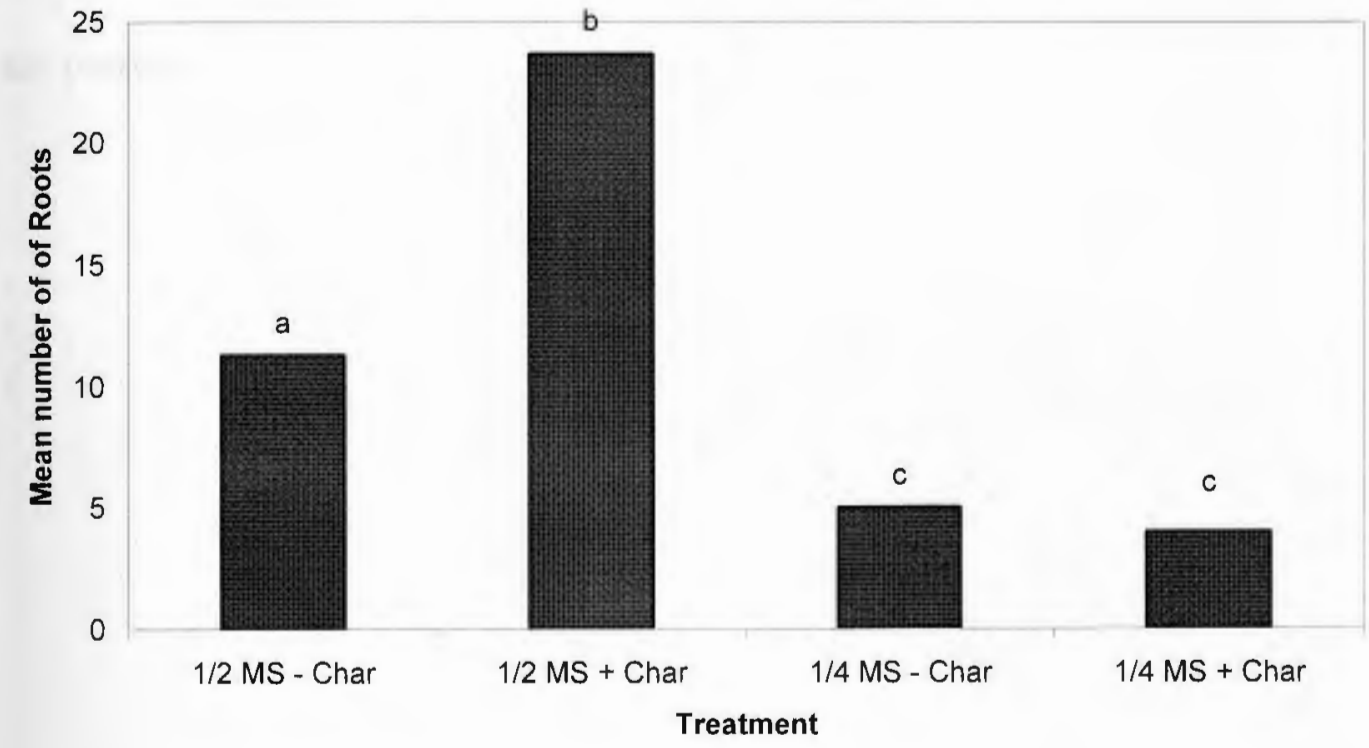

Figure 8. Mean number of roots produced per flask per treatment by seedlings of Darlingtonia californica in $1 / 2$ and $1 / 4$ strength liquid MS medium with and without charcoal. Incubation period was $61 / 2$ weeks. Columns denoted by the same letter were not significantly different. (Fisher's PLSD; for $\mathrm{ab}, \mathrm{P}=<0.0001$; for $\mathrm{ac}, \mathrm{P}=<0.02$; for $b c, P=<0.0001$ ) Experiments were repeated twice with similar results. 
Figure 9. Root production on proliferating seedlings of Darlingtonia californica after $6 \frac{1}{2}$ weeks of growth in liquid media.
A and B - Multiple root formation in liquid $1 / 2$ strength MS medium + charcoal (X3)
C - Double root formation in liquid $1 / 2$ strength MS medium + charcoal
D - Long roots formed in $1 / 2$ strength MS medium without charcoal - no multiple roots are present 

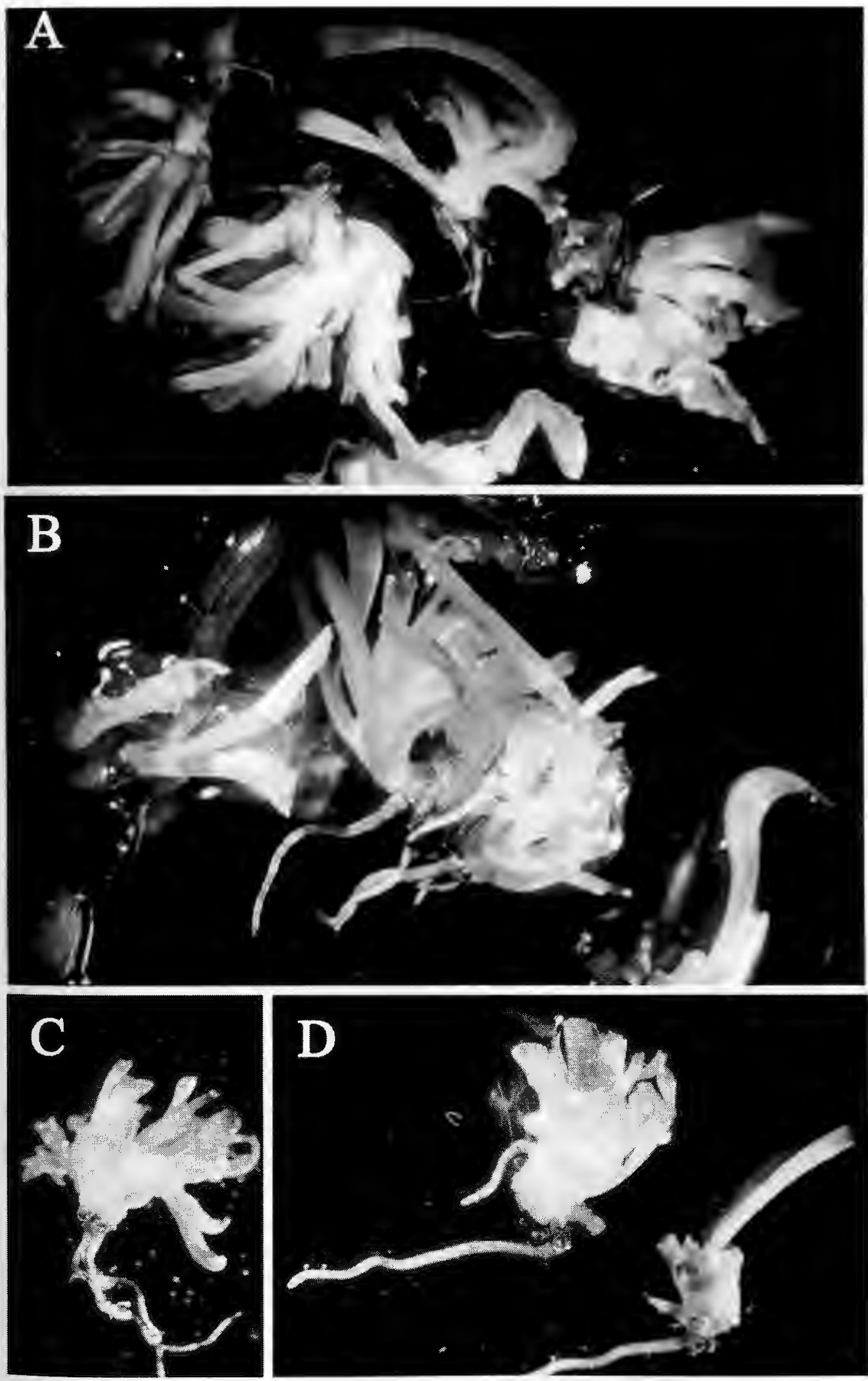
Figure 10. Root production of Darlingtonia californica after $61 / 2$ weeks of growth in liquid medium

A - (liquid 1/4 strength MS without charcoal) Several clusters of pitchers showing the absence of roots on the central rhizome (X3)

B and D (liquid 1/4 strength MS without charcoal) Roots when present were usually single in occurrence and short compared to media with charcoal (X3)

C - (liquid 1/4 strength MS with charcoal) Roots generally longer than in $1 / 4$ strength without charcoal but still singular in occurrence (X3) 

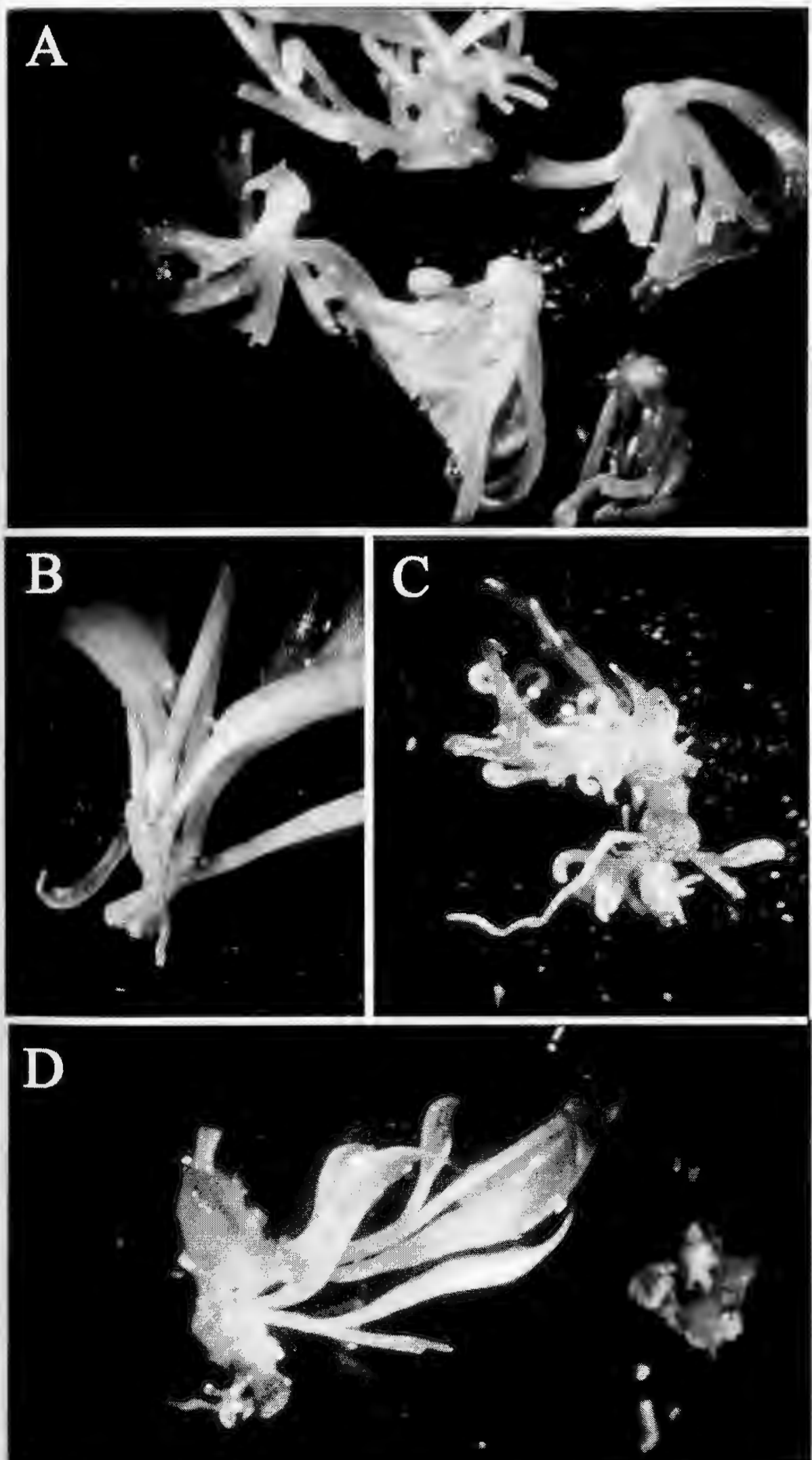


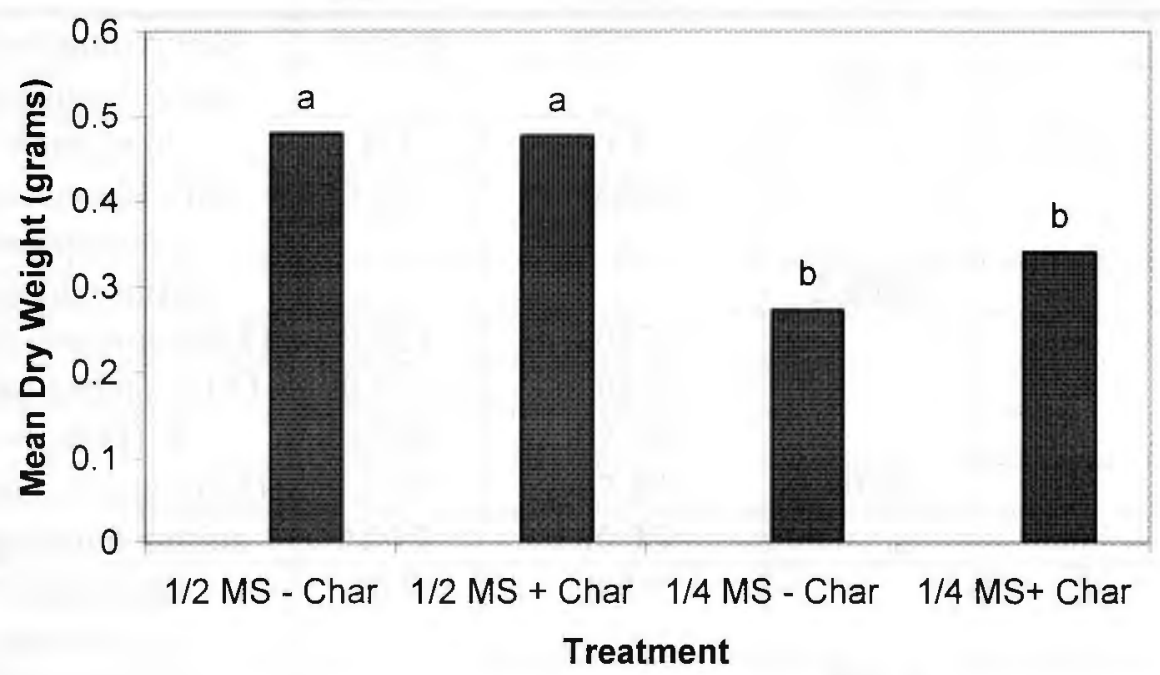

Figure 11. Mean dry weight of plant tissue produced per flask per treatment by seedlings of Darlingtonia californica in $1 / 2$ and $1 / 4$ strength liquid MS medium with and without charcoal. Incubation period was $61 / 2$ weeks. Each column represents the mean of three replicates. Columns denoted by the same letter were not significantly different. (Fisher's PLSD; P<0.007) Experiments were repeated twice with similar results. 
Table 1

Comparison of Media Formulations (mg/l)

\begin{tabular}{|c|c|c|c|c|}
\hline Medium Components & $\begin{array}{c}\text { Full } \\
\text { Strength } \\
\text { MS } \\
\text { Medium }\end{array}$ & $\begin{array}{c}\text { Phytomax } \\
\text { Orchid } \\
\text { Multiplication } \\
\text { Medium }\end{array}$ & $\begin{array}{c}\text { Burgeff's } \\
\mathrm{N}_{3} \mathrm{f} \\
\text { Medium }\end{array}$ & $\begin{array}{l}\text { Sphagnum- } \\
\text { Based } \\
\text { Medium }\end{array}$ \\
\hline Ammonium nitrate & 1650.0 & 825.0 & & \\
\hline Ammonium sulfate & & & 500.0 & \\
\hline Boric acid & 6.2 & 3.1 & & \\
\hline $\begin{array}{l}\text { Calcium chloride } \\
\text { (anhydrous) }\end{array}$ & 332.2 & 166.0 & & \\
\hline Calcium nitrate & & & $2,000.0$ & \\
\hline Cobalt chloride $6 \mathrm{H}_{2} \mathrm{O}$ & 0.025 & 0.0125 & & \\
\hline Cupric sulfate $\cdot 5 \mathrm{H}_{2} \mathrm{O}$ & 0.025 & 0.0125 & & \\
\hline $\mathrm{Na}_{2}$-EDTA & 37.26 & 37.24 & & \\
\hline Ferrous sulfate $7 \mathrm{H}_{2} \mathrm{O}$ & 27.8 & 27.85 & 40.0 & \\
\hline Magnesium sulfate & 180.7 & 90.35 & & \\
\hline $\begin{array}{l}\text { Magnesium } \\
\text { sulfate } \cdot \mathrm{H}_{2} \mathrm{O}\end{array}$ & 16.9 & 8.45 & & \\
\hline $\begin{array}{l}\text { Magnesium } \\
\text { sulfate } 4 \mathrm{H}_{2} \mathrm{O}\end{array}$ & & & 400.0 & \\
\hline $\begin{array}{l}\text { Molybdic acid } \\
\text { (sodium salt) } \\
\cdot 2 \mathrm{H}_{2} \mathrm{O}\end{array}$ & 0.25 & 0.125 & & \\
\hline Potassium chloride & & & 500.0 & \\
\hline Potassium iodide & 0.83 & 0.415 & & \\
\hline Potassium nitrate & $1,900.0$ & 950.0 & & $1,000.0$ \\
\hline $\begin{array}{l}\text { Potassium phosphate } \\
\text { (monobasic) }\end{array}$ & 170.0 & 85.0 & 500.0 & \\
\hline Zinc sulfate $\cdot 7 \mathrm{H}_{2} \mathrm{O}$ & 8.6 & 5.3 & & \\
\hline \multicolumn{5}{|l|}{ Organics } \\
\hline Agar & $8,000.0$ & $8,000.0$ & $8,000.0$ & $8,000.0$ \\
\hline $\begin{array}{l}\text { 6-Benzylaminopurine } \\
\text { (BA) }\end{array}$ & & 2.0 & & \\
\hline Casein hydrolysate & & & & 100.0 \\
\hline $\begin{array}{c}\text { Glycine } \\
\text { (free base) }\end{array}$ & 2.0 & & 2.0 & 2.0 \\
\hline
\end{tabular}




\begin{tabular}{|c|c|c|c|c|}
\hline Medium Components & $\begin{array}{c}\text { MS } \\
\text { Medium }\end{array}$ & $\begin{array}{c}\text { Phytomax } \\
\text { Orchid } \\
\text { Multiplication } \\
\text { Medium }\end{array}$ & $\begin{array}{l}\text { Burgeff's } \\
\mathrm{N}_{3} \mathrm{f} \\
\text { Medium }\end{array}$ & $\begin{array}{l}\text { Sphagnum } \\
\text { Based } \\
\text { Medium }\end{array}$ \\
\hline$\overline{\text { MES (free acid) }}$ & & $\overline{1,000.0}$ & & \\
\hline Myo-inositol & 100.0 & 100.0 & 100.0 & 100.0 \\
\hline $\begin{array}{l}\alpha \text {-Naphthaleneacetic } \\
\text { acid }\end{array}$ & & 0.5 & & \\
\hline $\begin{array}{l}\text { Nicotinic acid (free } \\
\text { acid) }\end{array}$ & 0.5 & 0.5 & 0.5 & 0.5 \\
\hline Peptone & & $2,000.0$ & & \\
\hline Pyridoxine $\cdot \mathrm{HCL}$ & 0.5 & 0.5 & 0.5 & 0.5 \\
\hline $\begin{array}{l}\text { Chopped live } \\
\text { Sphagnum }\end{array}$ & & & 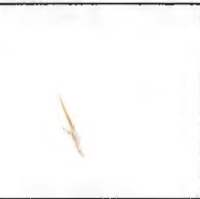 & $\begin{array}{l}500 \mathrm{ml} \\
\text { beaker, } \\
\text { loosely } \\
\text { packed }\end{array}$ \\
\hline Sucrose & $20,000.0$ & $20,000.0$ & $20,000.0$ & $20,000.0$ \\
\hline Thiamine $\cdot \mathrm{HCl}$ & 0.1 & 1.0 & 0.1 & 0.1 \\
\hline
\end{tabular}




\section{Literature Cited}

Adamec L (2002) Leaf absorption of mineral nutrients in carnivorous plants stimulates root nutrient uptake. New Phytol., 155: 89-100.

Arditti J (1982) Orchid seed germination and seedling culture - a manual. In: Orchid Biology - Reviews and Perspectives II. (pp. 246-310) Arditti, J. (ed) Comstock Publishing Associates, Cornell University Press. Ithaca, NY

Boulay J (1995) Les plantes carnivores, essais de micropropagation. Bull. Acad. Soc. Lorraines Sci. 34: 151-159

Franck DH (1975) Early histogenesis of the adult leaves of Darlingtonia californica (Sarraceniaceae) and its bearing on the nature of epiascidiate foliar appendages. Am. J. Bot. 62: 116-132

Dodds JH \& Roberts LW (1995) Experiments in Plant Tissue Culture. Third Edition. (pg. 43) Cambridge University Press. London

George EF \& Sherrington PD (1984) Plant Propagation by Tissue Culture. Exergenics Limited. Edington, UK 
Hu CY \& Wang, P.J. (1983) Meristem, Shoot Tip and Bud Cultures. In: Evans D.A., Sharp W.R., Ammirato P.V. \& Yasuyuki Y (eds) Handbook of Plant Cell Culture. (pp.177-227) Macmillan Publishing Co. New York.

Lloyd, E.F. (1942) The Carnivorous Plants. (pp.115-168) Chronica Botanica Co. Waltham, MA.

Murashige T \& Skoog F (1962) A revised medium for rapid growth and bioassays with tobacco tissue culture. Physiol. Plant. 15: 473-497

Redwood G. \& Bowling D (1990) Micropropagation of Nepenthes species. Bot. Gard. Microprop. News 1: 19-20

Reeves RD, Macfarlane RM \& Brooks RR (1983) Accumulation of nickel and zinc by western North American genera containing serpentine-tolerant species. Am. J. Bot. 70: 1297-1303

Schnell DE (2002) Carnivorous Plants of the United States and Canada. Second Edition. (pp. 229-242) Timber Press. Portland, Oregon 
Takayama S \& Misawa M (1980) Differentiation of Lilium bulbscales grown in vitro. Effects of activated charcoal, physiological age of bulbs and sucrose concentration on differentiation and scale leaf formation in vitro. Physiol. Plant. 48: $121-125$

Withner CL (1964) Notes on the cultivation of insectivorous plants in vitro. Bull. Torr. Bot. Club 91: 412-413

Ziv M (1979) Transplanting Gladiolus plants propagated in vitro. Sci. Hort. 11:257260 


\section{ESTABLISHMENT OF A MICROPROPAGATION SYSTEM FOR MEMBERS OF THE SARRACENIACEAE}

III.

\section{MORPHOLOGICAL RESPONSES DURING IN VITRO REGENERATION OF THE NORTH AMERICAN PITCHER PLANTS DARLINGTONIA CALIFORNICA TORRY AND SARRACENIA LEUCOPHYLLA RAF}

\section{ABSTRACT}

Darlingtonia californica was regenerated from whole, in vitro germinated seedlings and excised segments from in vitro generated juvenile pitchers. Whole 2 to 3-week-old seedlings produced protocorm-like bodies and green, leafy callus when cultured on solid Phytomax Orchid Multiplication Medium containing auxin and cytokinin. When divided and subcultured in liquid Phytomax Orchid Multiplication Medium, explants of both protocorm-like bodies and green, leafy callus gave rise to multiple shoots as well as more protocorm-like bodies and green, leafy callus. These could be further divided and subcultured. Transverse segments of excised pitcher leaves from axenically-grown seedlings produced shoots and protocorm-like bodies when subcultured in liquid Phytomax Orchid Multiplication Medium. Unlike $D$. californica, seedlings of Sarracenia leucophylla did not readily produce offshoots when incubated on solid media and propagation from a primary rhizome required physical division before subculture to liquid media containing hormones. A protocol for the extraction of intact embryos from selected Sarracenia species was developed. 


\section{INTRODUCTION}

This manuscript is part of a series reporting on the establishment of a micropropagation system for members of the Sarraceniaceae. Manuscripts I and II (this dissertation) describe techniques for the in vitro germination, growth and rooting of $D$. californica and the in vitro germination of $S$. leucophylla. These previous studies enabled the present investigation of regeneration. This manuscript describes techniques for the in vitro multiplication of $D$. californica and S. leucophylla with emphasis on the morphogenic potential of whole seedlings and excised pitcher leaves.

D. californica is a North American pitcher plant endemic to the states of Oregon and California (Schnell, 2002). S. leucophylla is a southern trumpet pitcher plant distributed along the southeast coast of the U.S. (Cheers, 1992). As with other members of the Sarraceniaceae, these plants have long been objects of interest and study for botanists (see Lloyd, 1942, for early references). Both species possess several attributes that make them suitable for studies in morphogenesis. The shoot systems of $D$. californica and $S$. leucophylla are heteroblastic. In $D$. californica both juvenile and adult pitcher leaves are tubular (epiasidate). However, juvenile leaves lack the hood, keel and fishtail appendage characteristic of the adult leaves (Frank, 1976). Juvenile pitcher leaves of S. leucophylla differ from the adult form in that they are narrow, and only gradually widen toward the mouth of the pitcher (Lloyd, 1942). They also lack the abaxial rolled margin present on the mouth of the adult form. Additionally S. leucophylla is the only member of the genus Sarracenia to form a complete new set of pitcher leaves at the end of the growing season (Schnell, 2002). 
Members of the Sarraceniaceae have similar pitcher leaf anatomy. The internal surface of pitcher leaves is divided into several morphologically distinct zones that can be distinguished by epidermal structures. While species and genera vary in the number and size of these zones, the zones function similarly in the attraction, capture and retention of prey and also in the digestion and absorption of nutrients (Givnish, 1989). MacDougal (1903) observed that when Sarracenia pitchers were placed in total darkness they doubled in length. He reported that this etiolation was caused by differential changes in zone lengths, with cell numbers increasing in some zones. These early observations indicate that renewed meristematic activity had occurred within some zones. MacDougal's observations are the basis of the pitcher segmentation experiments reported in this manuscript. Additionally, development of epiasidate leaves of the Darlingtonia type may be similar to carpel development (Frank, 1975). Carpel margins are formed by the fusion of two epidermal layers that retain considerable meristematic activity following fusion (Walker, 1975). The margins of $D$. californica pitcher leaves undergo a similar fusion (Frank, 1975), which may be associated with retention of meristematic activity.

In contrast to the above morphological similarities, $D$. californica and $S$. leucophylla differ considerably in their growth habit in the natural environment. Seedlings of $D$. californica establish a fibrous root system following germination and during early development of the seedling. Following the production of mature pitchers, the stem becomes plagiotropic, and roots are formed at the nodes (Frank, 1976). It also readily forms offshoots in its natural habitats. On the other hand, $S$. leucophylla reproduces vegetatively much more slowly in its natural habitats (Schnell, 
2002). These contrasting growth habits between two species with similar pitcher morphologies offer an opportunity to better understand differences and similarities in morphogenic potential across the two genera. Such an understanding may facilitate micropropagation of members of this and other pitcher plant families such as Nepentheaceae and Cephalotaceae in which epiasidate leaves are produced. Additionally, such studies are particularly timely and important since some members of the Sarraceniaceae have been placed on the endangered species list, e.g., $S$. oreophila and S. jonesii (Godt and Hamrick, 1996). To my knowledge, the literature does not contain any reports on in vitro morphogenic responses of D. californica or $\mathrm{S}$. leucophylla. 


\section{MATERIALS AND METHODS}

\section{Seed Germination}

Seeds of $D$. californica were obtained from a commercial supplier and germinated using Methods \# 2, \# 3, \#4 and \# 5 as described in manuscript 1 (Table 1) this dissertation.

\section{Callus Culture}

\section{Sequential culture of whole seedling on solid and liquid medium}

Seeds of $D$. californica were surface disinfested and germinated as described in method \# 4 (Table1, Manuscript I). Twelve 3 to 4-week-old seedlings were transferred to each of two, $500 \mathrm{ml}$ Erlenmeyer flasks containing $200 \mathrm{ml}$ of solid Phytomax Orchid Multiplication Medium (POMM, Sigma, St. Louis, Missouri), with $0.5 \mathrm{mg} / \mathrm{l} \mathrm{NAA}$ and $1.5 \mathrm{mg} / \mathrm{l} \mathrm{BA}$. The $\mathrm{pH}$ was adjusted to 5.0 prior to autoclaving and before addition of $8.5 \mathrm{~g} / 1$ agar (Bacto-agar, Difco, Detroit, Michigan, USA). Flasks were incubated in a growth chamber at $27^{\circ} \mathrm{C} \pm 2^{\circ}$ with $16-\mathrm{hr} \mathrm{d}^{-1}$ illumination at 170 $\mu \mathrm{mol} \mathrm{m} \mathrm{sec}^{-1}$.

Following five weeks of growth, protocorm-like bodies and green, leafy callus were removed from the flasks and subdivided into pieces 3-5 $\mathrm{mm}$ in length using a fine pointed scalpel and fine and medium pointed dissecting forceps. Subdivided tissue was distributed evenly among three, $50 \mathrm{ml}$ Erlenmeyer flasks containing $9 \mathrm{ml}$ of liquid POMM (pH 5.0). Culture flasks were incubated in a growth chamber as described above and gently swirled for 15-30 s, every other day. After 5 weeks of growth the tissue from two flasks was photographed in vitro, subdivided and distributed evenly among three, $250 \mathrm{ml}$ Erlenmeyer flasks, each containing $75 \mathrm{ml}$ of 
fresh medium. The third flask was sacrificed for drawing and observations.

Subcultured tissue was photographed after 4 weeks and returned to the growth chamber.

Culture of whole seedlings derived from $\mathrm{GA}_{3}$ stimulated and unstimulated seeds in liquid medium

Seeds of $D$. californica were germinated with and without $\mathrm{GA}_{3}$ (Methods \# 4 and \# 5, Table 1, manuscript 1). Thirty-two, 18-day-old whole seedlings from each treatment were transferred, 4 each, to eight, $25 \mathrm{ml}$ plastic culture flasks each containing $9 \mathrm{ml}$ of liquid POMM and incubated in a growth chamber as described above.

\section{Culture of whole seedlings in full strength liquid MS medium}

To assess the effect of full strength MS medium (Murishige and Skoog, 1962) on the growth and development of $D$. californica, 12, 25-day-old seedlings (germinated using Method \#4, Table 1, Manuscript 1) were transferred to two, $250 \mathrm{ml}$ Erlenmeyer flasks (6 seedlings per flask) containing $75 \mathrm{ml}$ of liquid MS medium without hormones. Flasks were incubated in a growth chamber (described above) and examined after 28 days of culture.

\section{Pitchers from $\mathrm{GA}_{3}$-stimulated seeds germinated on solid medium}

Seeds of $D$. californica were germinated as described for Method \# 5 (Table 1, Manuscript 1), except that seeds were exposed to $\mathrm{GA}_{3}$ for 12 days instead of $24 \mathrm{~h}$ and forty seeds were transferred to each of two, $250 \mathrm{ml}$ Erlenmeyer flasks containing 75 $\mathrm{ml}$ of solid POMM ( $8.5 \mathrm{~g} / \mathrm{l}$ agar). Following germination, seedlings were allowed to grow for 2 months. 


\section{Pitchers from seeds germinated in liquid medium without GA $_{3}$}

Seeds of $D$. californica were surface disinfested and germinated using Method \#1 (Table 1, Manuscript 1) in $50 \mathrm{ml}$ Erlenmeyer flasks and placed on a gyrotary shaker $(120 \mathrm{rpm})$ at room temperature and light conditions. Following 3 months of culture, dense clusters of pitchers were removed and divided. Two clusters (each cluster containing approx. 9-12 pitchers) were transferred to each of three, $500 \mathrm{ml}$ Erlenmeyer flasks containing $50 \mathrm{ml}$ of liquid POMM and placed in the growth chamber.

\section{Organogenesis from whole or fragmented pitchers}

Pitchers harvested from seedlings derived from $\mathrm{GA}_{3}$ stimulated seeds cultured on solid medium were cut into fragments approximately $3-5 \mathrm{~mm}$ in length. Six to seven fragments (representing a single pitcher) were transferred to each of three, $50 \mathrm{ml}$ Erlenmeyer flasks containing $10 \mathrm{ml}$ of liquid POMM and placed in the growth chamber. Observations were made over a 45 day period.

Whole pitchers (1-2 cm long) derived from seedlings not exposed to $\mathrm{GA}_{3}$ and cultured for 45 days in liquid medium were carefully excised using a fine pointed scalpel, fine and medium pointed forceps and a pair of fine pointed iridectomy scissors. Care was taken to insure that rhizomateous tissue was not included at the base of the excised pitchers. In order to ascertain regeneration potential within anatomical pitcher zones, excised pitchers were subjected to the following treatments: 1) whole pitchers were placed (one each) in each of six, $125 \mathrm{~mm} X 25 \mathrm{~mm}$ Pyrex test tubes containing $8 \mathrm{ml}$ of liquid POMM;2) whole pitchers were cut into $2-3 \mathrm{~mm}$ sections and the fragments of 2 pitchers were placed in each of six tubes; 3 ) whole 
pitchers were cut in half and the distal portions placed in one set of six tubes and the basal portions in another set. Additionally, two whole seedlings, 5-months-old and maintained on $1 / 2$ strength MS medium, were transferred, one each, to each of 2 tubes.

This experiment was repeated one month later with modifications. Pitchers were excised as described above, but pitcher length was $1.0-1.8 \mathrm{~cm}$. Five treatments were employed (15 test tubes per treatment, each with $10 \mathrm{ml}$ of POMM): 1) whole excised pitchers, one per tube 2) distal half of pitcher, one per tube; 3) basal half of pitcher, one per tube; 4) distal half fragmented (3-4 fragments), one set per tube; 5) basal half fragmented (3-4 fragments), one set per tube. Additionally, pitchers approximately $1.8 \mathrm{~cm}$ in height were cut into nine fragments with the center fragment excised first (fragment \#5) and placed one each, in numbered tubes. This was replicated 4 times. The duration of this experiment was 30 days.

\section{Multiplication of S. leucophylla in vitro}

Two, 2-week-old seedlings of $S$. leucophylla that had germinated on MYP (from surface disinfestations experiments Manuscript 1, this dissertation) were transferred to $10 \mathrm{ml}$ of $1 / 2$ strength MS medium + vitamins in $125 \mathrm{~mm} \times 25 \mathrm{~mm}$ test tubes and placed in a growth chamber. Temperature and light conditions were as described in Manuscript 1, this dissertation. After 30 days they were transferred to solid POMM. After two months of growth they were subcultured to a $500 \mathrm{ml}$ Erlenmeyer flask containing $50 \mathrm{ml}$ of liquid POMM. After 105 more days the remaining tissue was divided into several pieces, each containing a portion of the rhizome and several pitchers, and distributed among three, $250 \mathrm{ml}$ Erlenmeyer flasks, each containing $75 \mathrm{ml}$ of liquid POMM. Four pitchers were excised from rhizomes 
and cut into seven fragments each and placed randomly in 4,25 ml plastic culture vessels each containing $9 \mathrm{ml}$ of liquid POMM. Following another 45 days of culture the growth in the flasks was documented photographically.

\section{Extraction of intact endosperm and embryos}

Seeds of S. leucophylla and S. purpurea were treated in concentrated $\mathrm{H}_{2} \mathrm{SO}_{4}$ for $10 \mathrm{~min}$ followed by three, $5 \mathrm{~min}$ rinses in sterile distilled $\mathrm{H}_{2} \mathrm{O}$ and then dissected and the embryos removed. Dissections and extractions were performed with the aid of a dissecting microscope, fine pointed forceps, and micro-dissection needles. A fine pointed hypodermic needle attached to the blunt end of a dental pick served as a micro-scalpel. Seed coats were split, by making a single, incision along the long axis of the seed. Portions of the micropylar and chalazal end of the seed were removed with the micro-scalpel and the coat gently teased away from the endosperm using forceps and micro-dissection needles. After removal of the seed coat, an oblique cut was made across the micropylar region of the endosperm. Embryos were teased out by manipulation and gentle pressure on the chalazal end and/or by carefully removing layers of endosperm tissue using the edge of a micro-scalpel as a micro- scraper. Alternatively, following treatment in acid, seeds were placed in $3 \mathrm{ml}$ of sterile $\mathrm{H}_{2} \mathrm{O}$ in $1.5 \mathrm{ml}$ plastic centrifuge tubes and spun on a vortex mixer for $3 \mathrm{~min}$. followed by a change of $\mathrm{H}_{2} \mathrm{O}$ and gentle agitation with the tip of a sterile Pasteur pipet. This process was repeated several times until most or all of the seed coats were removed. Residual coat material was removed under the dissecting microscope by gentle teasing using micro-dissection instruments. Embryos were extracted as described above. These 
procedures were performed on the lab bench or, in order to obtain sterile material for experiment, in a laminar flow hood. 


\section{RESULTS}

\section{Production of protocorms and callus from tissue derived from whole seedlings by}

sequential culture on solid and liquid medium

When 4-week-old seedlings were placed with their longitudinal axis flush against the surface of POMM (Fig.1A), seven of 12 began to brown during the first week of culture. These seedlings were completely brown by the end of the second week and produced no new growth for the duration of the experiment. Five seedlings remained green with some yellowing of the hypocotyls and cotyledons ( 3 in flask 1,2 in flask 2). Their cotyledonary nodes began to green and swell during the second week, forming hard green callus and/or green leafy callus (GLC) by the end of week 3 . These growths eventually obscured the cotyledonary nodes and also appeared along the hypocotyls proximal to the node. GLC also arose basipetally toward the root tip. No increase in length of the cotyledons, hypocotyls, or primary root was observed. After 70 days of culture two hard callus masses resembling orchid protocorms (protocorm-like bodies, PLB) had formed (Fig.1B). The GLC remained leafy (Fig. 1C) and many small, spherical, bud-like structures appeared on the surface of the tissue. These structures formed on both types of callus and were morphologically similar to developing orchid protocorms (Fig.1D). Similar callus forms in leaf cultures of Cattleya orchids (Fig.1E). When removed for subculture (first subculture) the GLC was more friable than the PLB. After approximately 15 days of subculture, both PLB and GLC began to form new shoots, GLC and spherical bud-like structures, which later formed PLB. PLB could sometimes be separated from parent tissue by gently swirling the medium in the flask, and larger PLB sometimes separated 
spontaneously in culture. These large PLB resembled mature orchid protocorms (compare Fig.2Aand 2B). After 44 days of subculture, dense clumps of pitchers and callus were produced (Figs. 2C and 2D). The cultures appeared healthy and new growth initiated from the circumference of the collective tissue mass.

When the masses were divided for subculture (second subculture) numerous plantlets lacking roots, large and small PLB, and various amounts of GLC in several stages of development were observed. Tissue masses were divided into several large clusters, but the original explant tissue could not be identified. Yellowing and browning of some tissue during the first week of the second subculture was followed by a 1 to $1 \frac{1}{2}$-week quiescent period before new growth was observed. A color change from yellow-green to green was the first indication that growth had resumed. After 45 days of growth the flasks were photographed (Fig.3And B). Shoots generated from subcultures of PLB and GLC were morphologically similar to shoots produced from whole seedlings (Fig. 3C). As of this writing the flasks are in a growth chamber and have produced a large amount of tissue for further subculture and experimental use.

\section{Production of callus from whole seedlings derived from $\mathrm{GA}_{3}$ stimulated and unstimulated seeds and cultured in liquid medium}

After 36 days of subculture five seedlings in the treatment without $\mathrm{GA}_{3}$ had swollen nodes and leaf bases and had produced new pitchers (Fig.4A, compare with Fig. 1A). PLB and GLC were present on only 1 of these seedlings. The others had completely browned by the end of the experiment. In contrast, eight of 16 seedlings from seeds stimulated by $\mathrm{GA}_{3}$ showed new green growth and on 3 of these PLB and 
GLC could be observed (Fig. 4B). The remaining 8 seedlings either browned or yellowed by the time the experiment was terminated and produced neither PLB nor GLC.

\section{Culture of whole seedlings on full strength liquid MS medium -}

When 12, 25-day-old seedlings were cultured in full strength MS medium, no evidence of multiplication or morphogenesis was observed after 30 days (Fig. 4C). One seedling browned, and 11 remained green with some yellowing. Some browning of pitchers was observed.

\section{Organogenesis from whole and fragmented pitchers}

When fragments of pitchers harvested from plants grown from $\mathrm{GA}_{3}$ stimulated seeds on solid medium were cultured in liquid POMM, new growth was observed in 2 of 3 flasks after 45 days (Fig. 5A). One fragment of 7 in flask \#2 has formed 5 welldeveloped pitcher leaves (Fig. 5B) and several small PLB were clustered around the center of leaf origin (Fig. 5B). These small PLB could be separated from the parent tissue (Fig. 5C). In flask \# 3, two of seven fragments had produced two PLB (Fig. 4D and E). One PLB had given rise to a cluster of small pitchers (Fig. 4D). In this experiment three of 20 pitcher fragments produced new growth. All six pitcher fragments in flask \#1 gradually browned and died.

The pitchers used as source material for subsequent experiments were plantlets derived from non-GA3 treated seeds and subcultured in liquid POMM for 45 days. During this time the plantlets multiplied and completely covered the bottom of the flask (Fig. 6A). A few small roots originating from central cluster rhizomes were 
visible with the aid of a hand-lens. The plantlets appeared chlorotic at the time pitchers were excised and fragmented.

In four of the six tubes in which pitcher fragments were cultured, new growth occurred.(Fig. 6B). Eleven of a total of 50 fragments produced new growth, and the rest slowly browned. In tubes one and two, 4 fragments produced new growth, tube three contained 10 fragments with two producing new growth, all fragments browned in tubes four and five, and one fragment in tube six produced new growth. The fragments varied from small spherical bodies (Fig. 6B, inset), small PLB, to large hard, dark green callus (Fig. 6B). PLB closely resembled orchid protocorms (Fig. 6C, compare to Fig.1D). Whole pitchers usually turned brown, usually starting from the basal end. Most had completely browned after 3 weeks of culture. Both distal and basal halves of pitchers slowly browned and died with the basal halves browning more quickly than the distal halves. The distal tip of whole pitchers and distal halves sometimes remained green and became somewhat translucent and yellow before finally browning. Whole seedlings ultimately turned brown. However, one started to show new growth at the end of the experiment. This growth appeared to be from pitcher elongation and was accompanied by dark green coloration. Adventive structures were not observed.

The variable results noted above indicate that morphogenic potential of pitcher fragments may depend on the zone of the pitcher from which fragments were derived, so fragments were cultured individually and their position within the pitcher was noted when the experiment was repeated. However, very little regeneration was obtained in this experiment. One of 15 whole pitchers showed new growth from the tip (Fig. 7A) 
after 30 days of subculture. One of 15 basal halves of bisected pitchers formed a PLB and leaf-like structures at the distal end. This growth lost its coloration in the last 10 days of the experiment (Fig. 7B). No growth was observed in any other explants. Whole pitchers usually browned first from their basal ends and after one week of culture, the distal ends appeared larger and more translucent and were the last area to brown. Fragmented pitcher halves were paired so that fragments of the same pitcher were in adjacent tubes. Although all ultimately turned brown, the process of browning commenced at different times during the experiment and appeared synchronized between complementary tubes containing fragments of the same pitcher. The same was true for serially sequenced fragments. All fragments from the same pitcher began to brown at approximately the same time. Browning first appeared in the basal fragments in all treatments.

\section{Multiplication of Sarracenia leucophylla in vitro}

Seedlings of S. leucophylla grew slowly on solid $1 / 2$ strength MS medium. After two months of growth they had produced few pitchers and showed little tendency toward adventive multiplication. Transfer to solid POMM did not appear to have much effect. Although they did produce more pitchers and rhizome length appeared to increase slightly. Following transfer to liquid POMM, clusters of pitchers were formed. Pitcher clusters could be divided by rhizome cutting and subculture of clusters resulted in rapid multiplication, continued increase in pitcher height, and developmental movement toward adult pitcher morphology (Fig. 8A, B, and C).

Excised pitcher fragments gradually browned and died. No new growth was observed on any of the subcultured pitcher fragments after 45 days of subculture. 


\section{DISCUSSION}

\section{Conditions for the production of protocorm-like bodies and callus}

Because whole, axenically germinated seedlings have been used to initiate clonal multiplication through direct differentiation of shoots in several micropropagation systems (Malik and Saxena, 1992; Teo et al., 2001; Parliman et al., 1982a), the formation of callus and PLB from whole, in vitro germinated seedlings of D. californica was unexpected. Additionally, Rathore et al. (1991) reported the recalcitrance of whole, in vitro generated seedlings of the rare pitcher plant Nepenthes khasiana to produce callus when exposed to phytohormones in culture. In contrast, during this study, $D$. californica readily produced several types of callus and regenerative tissue distinguishable by differing gross morphology. During the last three decades of tissue culture, hypocotyls and cotyledons have been excised from axenically germinated seedlings of a variety of plant species and subcultured to initiate callus and somatic embryogenesis (see Kohlenbeck, 1978, for early review of somatic embryogenesis).

Similar developmental phenomena also were observed by Truscott (1966) in his studies of morphogenesis in Cuscuta gronovii. He observed that original explants (extracted, intact embryos) showed little development but gave rise to many adventive buds. Callus-like outgrowths formed at the bases of adventive buds and eventually formed many smaller buds. These phenomena are similar to that observed in whole cultured seedlings of $D$. californica. Additionally, Parliman et al., (1982b) described similar structures arising from cultured leaf tissue of D. muscipula. These structures were considered to be adventitious. Also, they report that in mature cultures, only the 
first bud appears to be adventitious and the subsequent buds appear to be lateral buds derived in sequence from it. This could also be the case in $D$. californica since preformed buds most likely do not occur on the hypocotyls and cotyledons.

Although histological studies were not performed during this study, the nature of PLB and GLC can be interpreted based on the anatomy and growth habit of the shoot system of $D$. californica seedlings. During leaf development in $D$. californica the newest emerging leaf forms a clasping base that nearly encircles the leaf primordium of the next developing pitcher leaf (Frank, 1976). This imbricate developmental pattern places axillary buds in close proximity prior to internode elongation. If these buds are activated by the presence of phytohormones they may give rise to the structures described in this manuscript as PLB. These structures would appear clustered at shoot tips. Alternatively, PLBs produced along the hypocotyls and cotyledons may be adventitious buds (Goebel's "Anlagen" - see Appendix C).

The ability of PLB and GLC to proliferate when divided and subcultured was not surprising since, at the time of division, considerable cytodifferentiation and morphogenesis had occurred. When transferred to fresh medium, the rapid formation of many shoots in dense clusters may have been the result of simultaneous activation of the PLB produced during the initial culture period. This rapid formation of shoots in dense clusters supplies evidence that PLB are bud-like in behavior.

The initial yellowing and dieback of some pitchers after subculture may have been associated with medium $\mathrm{pH}$. Although $\mathrm{pH}$ was not monitored during culture, a change from the original $\mathrm{pH}$ of 5.0 may have occurred. Liquid cultures of the Australian pitcher plant Cephalotus follicularis were observed to die back when 
transferred to fresh medium (Adams et al., 1979). It was suggested that this phenomenon was $\mathrm{pH}$ dependent because it occurred when medium at $\mathrm{pH} 5.7$ was used for subculture.

In this study lack of rooting may have been due to high auxin levels. The auxin in the medium coupled with the natural production of auxin by proliferating shoots may have led to levels inhibitory to root development. High auxin levels have been shown to cause callus formation at the shoot base of in vitro cultured plants and inhibit root formation (Lane, 1979).

\section{Effect of $\mathrm{GA}_{3}$ stimulation on whole seedlings cultured in liquid medium}

The lack of response of seedlings, without prior $\mathrm{GA}_{3}$ stimulation, to incubation in liquid medium with phytohormones is puzzling. Protocorm-like bodies and green, leafy callus were produced by non-stimulated seedlings cultured on the same medium in solid form. Seedlings transferred to solid medium were 21-28 days old vs. 15-18 days old for the seedlings transferred to liquid medium. It has been established that response in culture varies considerably in some species depending on physiological age, endogenous hormone concentrations as well as the history of the explant material (Hu and Wang, 1982).

The death of seedlings incubated in full strength MS medium was not unexpected. In nature, carnivorous plants generally inhabit nutrient poor habitats (Adamec, 1997) and media containing reduced salt concentrations have been successfully employed for in vitro culture of these plants. 


\section{Regenerative potential of fragmented pitchers}

This series of experiments tested the hypothesis that regenerative potential varies throughout specific zones of pitcher leaves of the Sarraceniaceae. This hypothesis was based on earlier observations on elongation potential of etiolated pitcher leaves of Sarracenia (MacDougal, 1903), the mode of leaf histogenesis (Frank, 1975,1976) and carpel development (Walker,1975). Walker describes placental tissue as arising from the fusion of two carpel epidermal layers which redifferentiate as placental tissue with great morphogenic potential (production of ovules). Fusion of epidermal layers also occurs during leaf histogenesis in the Sarraceniaceae, ultimately resulting in the familiar wing of Sarracenia purpurea and the keel of Darlingtonia californica. In other species of Sarraceniaceae this fusion line has been termed a suture (Lloyd 1942).

The adaxial surface of the pitcher leaf (the boundary between the interior of the pitcher and the external environment) is a highly differentiated epidermis occurring in discrete zonation. Each zone is characterized by specific epidermal structures such as downward pointing hairs, smooth waxy surfaces and, in some cases, digestive or absorptive glands. These zones function to direct the prey into the interior of the pitcher and in digestion and absorption of nutrients. The suture line, or wing, formed by the fusion and subsequent transdifferentiation of epidermal tissue is vascularized and continuous through all zones from the base of the pitcher to its tip (see Lloyd 1942, pp.19-36). Because pitcher development was continuous in vitro, it was hypothesized that pitchers fragmented to approximate the natural zonation might 
retain regenerative or developmental potential either at zone boundaries or along the suture line.

The first experiment was performed to quickly assay the ability of randomly fragmented pitchers to produce new growth from the excised fragments. The results of this experiment supported the hypothesis with new growth in the form of PLB, pitcher leaves and one whole plantlet being produced from several of the fragments.

In a second experiment, fragmented whole pitchers produced PLB, small green spherical bodies, and large, dark green callus. Why the cultured whole, distal, and basal halves of pitchers ultimately browned and died is not understood. One possibility is, the fragmented pitchers may be stimulated by a collective wound response to produce callus because of the number of wounded fragments placed together in the same test tube. This response may not have occurred in the tubes containing whole or half pitchers because of a low level of signal molecules since less wound surface area was exposed to the medium. Another possibility is that the tissue zone or zones capable of the response were located interior to the cut and may require being cut in order to initiate the response. These hypotheses could not be investigated because all the fragments from one pitcher were placed collectively in individual test tubes.

Although the results of the last experiment in this series were inconclusive some useful information was gathered. For instance, whole pitchers usually browned from the basal end first with the browning proceeding acropetally. The distal tips were also observed to become enlarged and translucent before ultimately browning. The only growth to appear from whole pitchers was from the distal end. These three 
observations, though based on a small sample size, suggest that a closer look at the distal zone may be the first step in planning future investigations. Additionally, because regenerative structures were produced by tissue with prior exposure to $\mathrm{GA}_{3}$ and tissue without $\mathrm{GA}_{3}$ exposure, the role of this hormone in the induction of renewed meristematic activity, as observed in these experiments, still remains unclear.

\section{Multiplication of Sarracenia leucophylla in vitro}

The slow growth of S. leucophylla on solid medium without hormones may be related to its natural habit. In nature this species does not proliferate by extensive secondary rhizome formation as does $D$. californica (Schnell, 2002). Instead, it produces new shoots from the primary rhizome. Commercial propagation is accomplished through cuttings taken from the primary rhizome that include at least one root (Pietropaolo and Pietropaolo, 1986, D'Amato, 1998). This form of propagation is very slow and faster rates may be obtainable through in vitro culture. Additionally, cuttings must be taken them just before the new growing season. This restriction does not apply to in vitro culture.

The lack of response of S. leucophylla when transferred to solid POMM containing auxin and cytokinin may have been caused by its previous long period of culture on solid medium. Prolonged culture with depletion of nutrients and leaching of toxic metabolites from the plants into the medium may have caused arrested growth. This hypothesis is supported by its rapid proliferation and growth when transferred to liquid POMM. Serial subculturing can break the recalcitrant state of many species as well as transfer to a liquid shaking system (Hu and Wang, 1984). 
Renewed initiation of growth and multiplication of $S$. leucophylla occurred when transferred to liquid medium without shaking.

Failure of pitcher fragments of S. leucophylla to form new growth in liquid culture could be due to one of several factors including developmental age, an inherent inability to form new centers of meristematic activity, or the sample size may have been too small.

\section{Extraction of intact endosperm and embryos}

The removal of seed coats using the vortex mixer method was preferable over the first method outlined. It allowed more seeds to be processed in a shorter time and extensive manipulation of seeds to completely remove the coat was usually not necessary. With practice, success rates reached seven out of 10 attempts and often the endosperm could be left intact with the exception of a small incision at the micropylar pole. This occurred when gentle pressure at the chalazal pole forced the embryo to slide out through the incision. Success was dependent upon the position of the embryo within the endosperm. 


\section{Summary}

Darlingtonia californica can be multiplied either through serial subculture of aseptically germinated seedlings or from fragmented juvenile pitchers in medium containing phytohormones. A variety of morphogenic responses are rapidly inducible with a commercial medium (POMM). This suggests $D$. californica as a suitable research organism for continued study of regeneration events and for optimization of a system for micropropagation.

Sarracenia leucophylla is promising as a subject for micropropagation but its use as a research organism may be limited until techniques to initiate in vitro responses are developed. However, the establishment of a protocol for the surgical extraction of intact endosperm and embryos of Sarracenia species can provide material to test the suitability of these species for endosperm and embryo culture experiments.

This study has achieved the initial steps in the stimulation of morphogenic responses in D. californica and has brought $S$. leucophylla into the study arena. Additional concerns are success in ex vitro acclimatization of plantlets and effects of long-term culture on genetic stability. 
Figure 1. D. californica-Production of callus and protocorm-like bodies on semisolid medium

A - Whole seedling of $D$. californica $(\mathrm{X} 10)$

B - Protocorm-like bodies formed from seedlings D. californica of PLB (X1.2)

C - Leafy green callus (X1.2)

D - Orchid protocorms (redrawn from Morel, 1974) (X10)

E - Callus produced from Cattleya leaf culture (redrawn from Morel, 1974) (X4) 

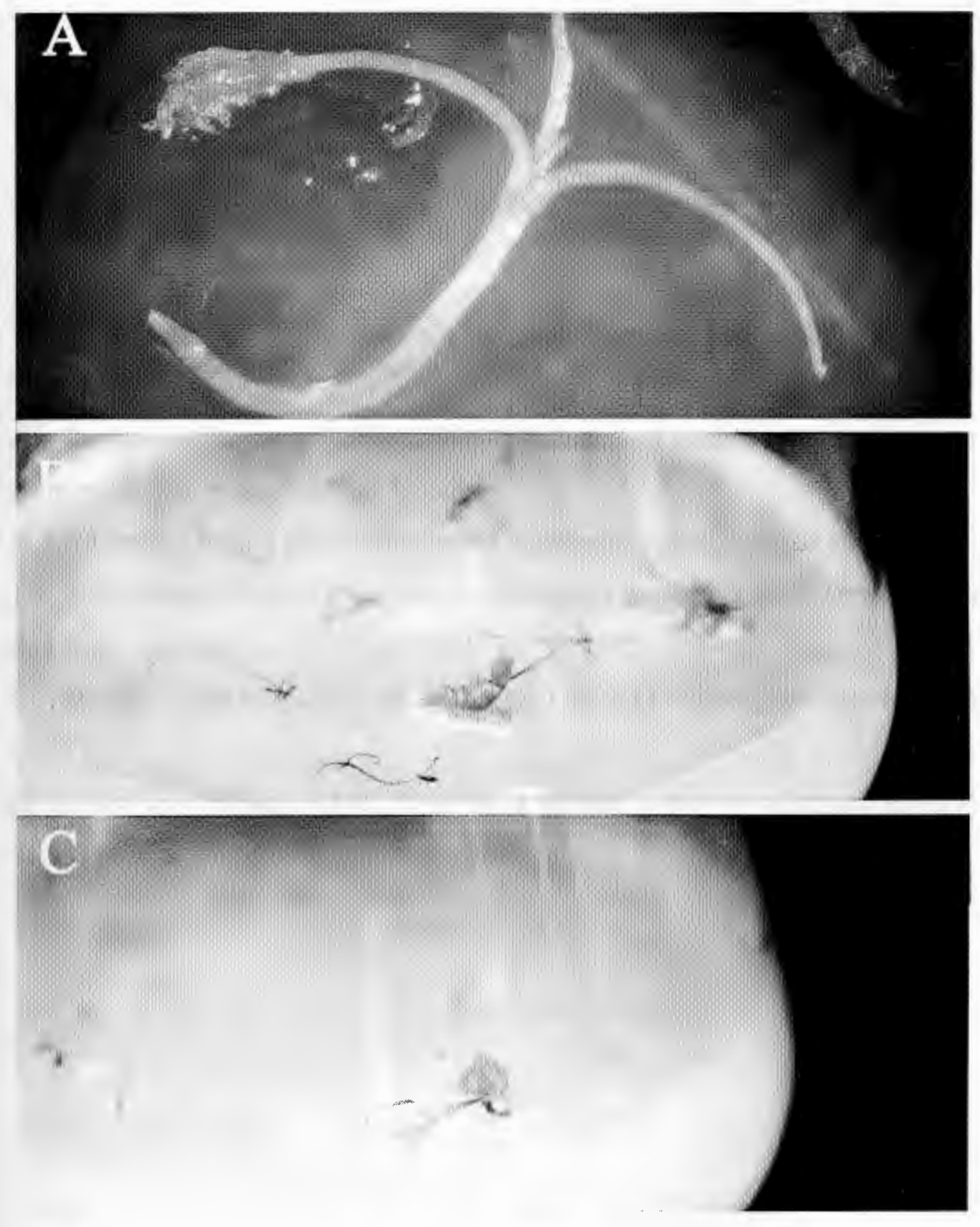

D
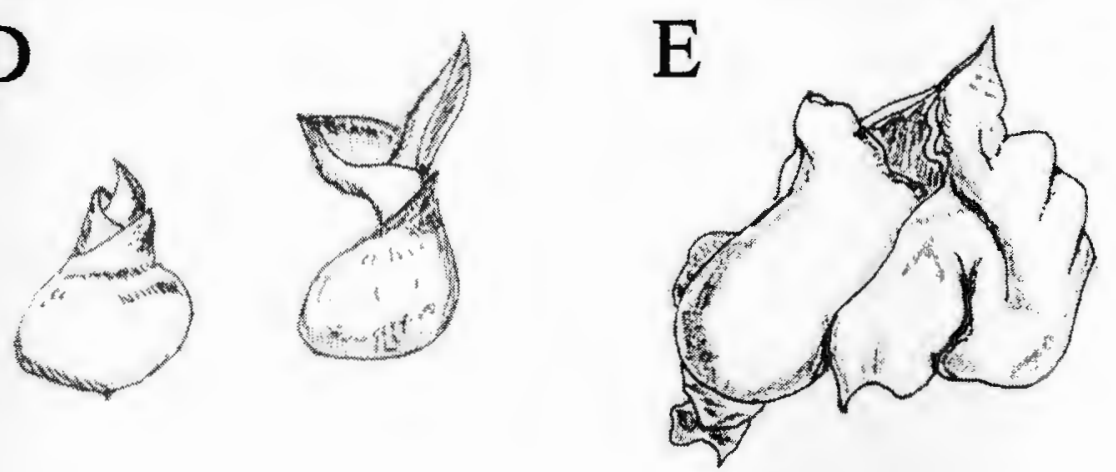
Figure 2. D. californica-Comparison of protocorm-like bodies with orchid protocorms - proliferating masses of pitchers and tissue

A - Protocorm-like body that separated spontaneously from parent tissue during liquid culture (drawn by Leslie Anne Uhnak).

B - A Cattleya orchid protocorm similar in morphology to the PLB shown in Fig.

1A. It has been cut for in vitro culture in the same manner as PLB were prepared in this study (redrawn from Morel, 1974).

C - Dense clumps of pitchers and callus after 44 days of liquid culture in POMM $(\mathrm{X} 0.7)$

D - Close-up of a flask in Fig. 2C showing various tissue responses and new growth new growth at the edge of the tissue mass 

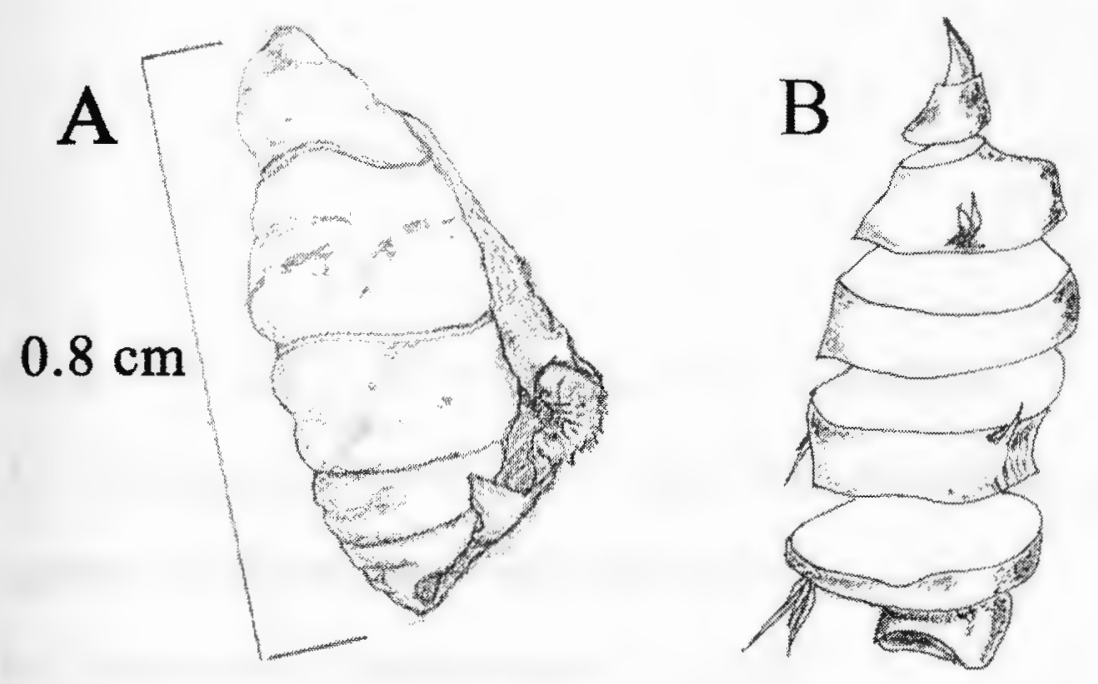

th- $2.5-3 \mathrm{~mm}$
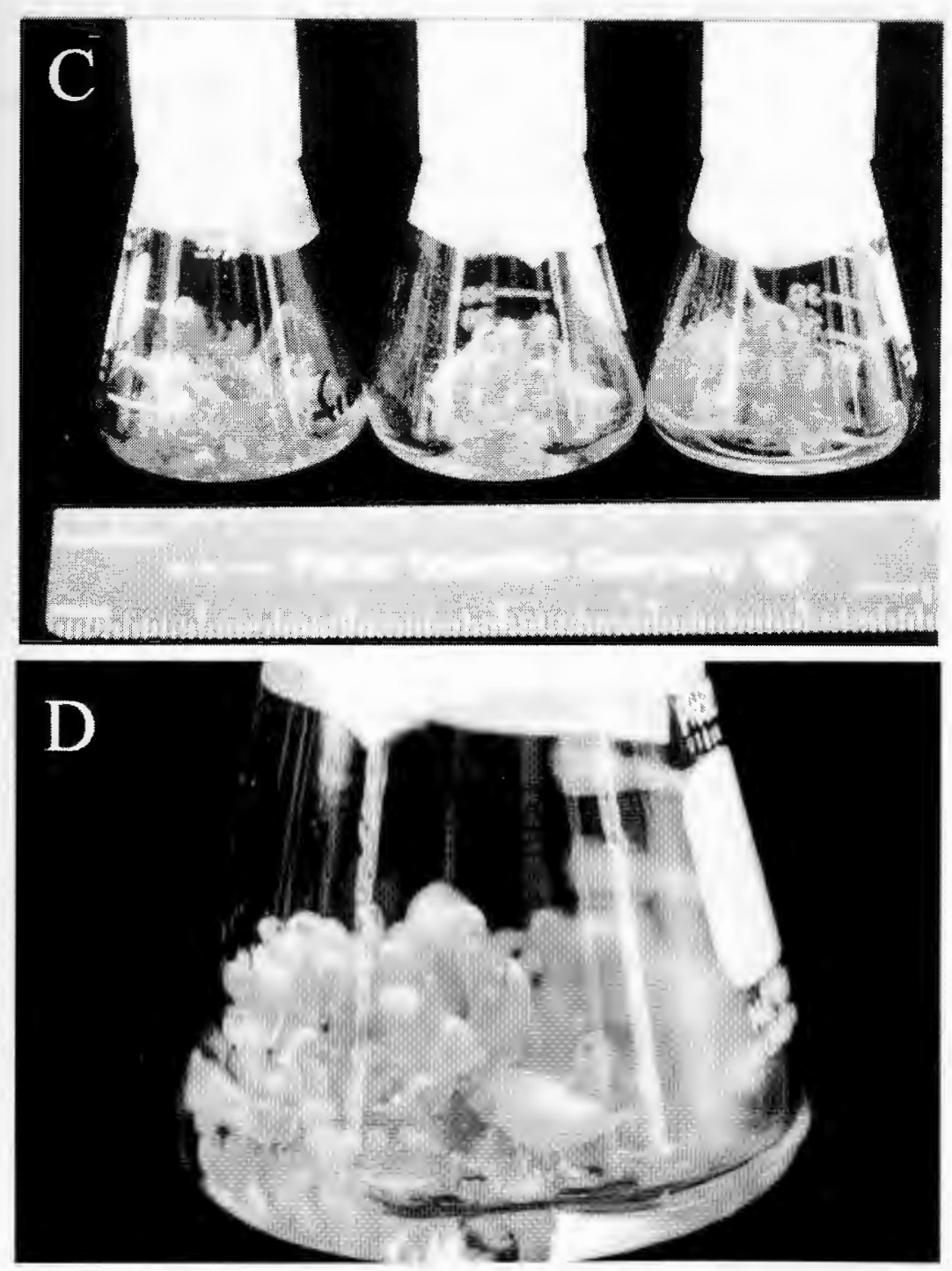
Figure 3. D. californica- In vitro growth and multiplication A - Multiplication of D. californica subcultured several times (original explant material was PLB and green leafy callus) (X0.7)

B - Bottom view of flask shown in Fig. 3A (X1)

C - Multiplication of D. californica from subcultured aseptically germinated seedlings (X1.1) 

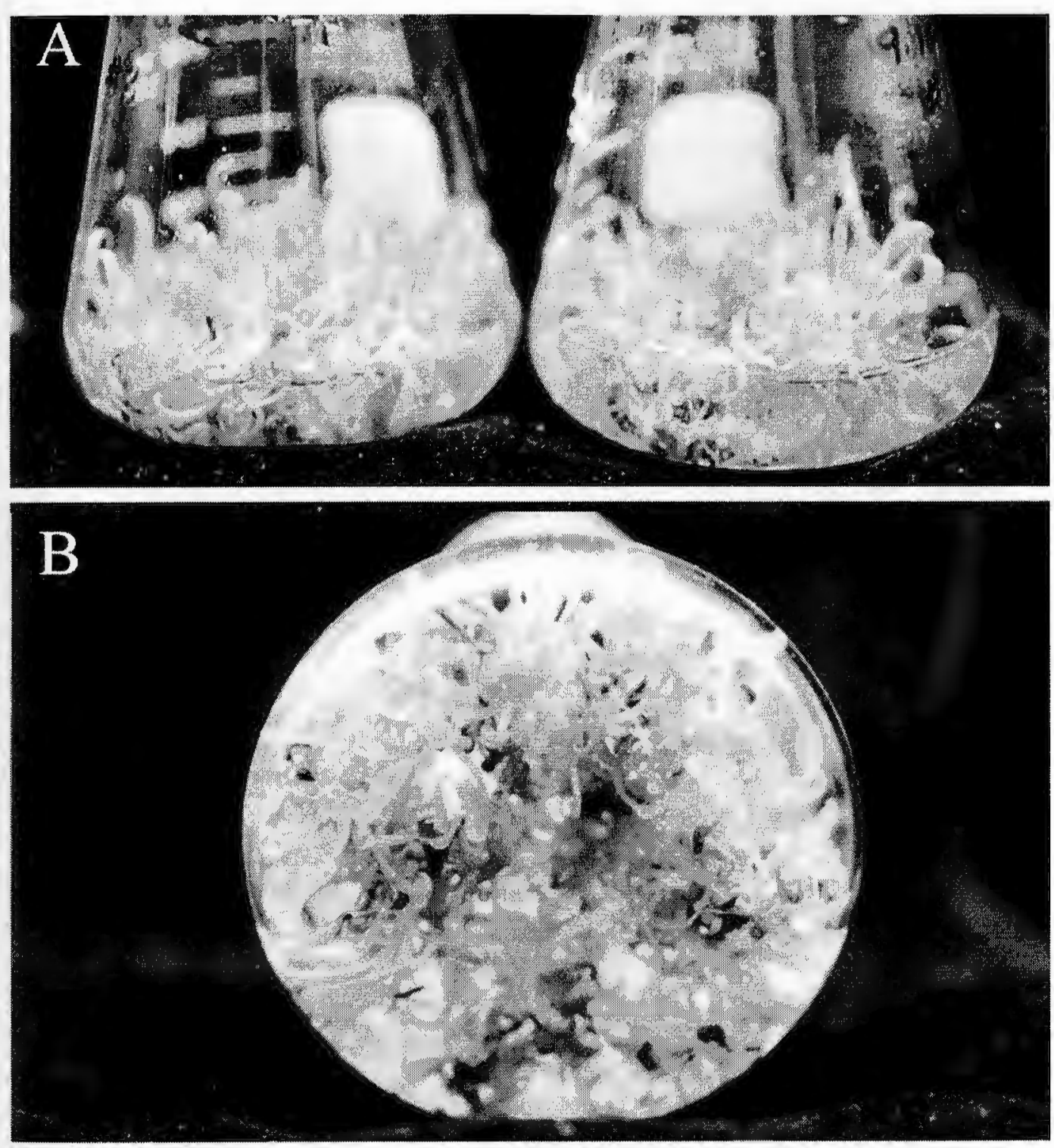

C

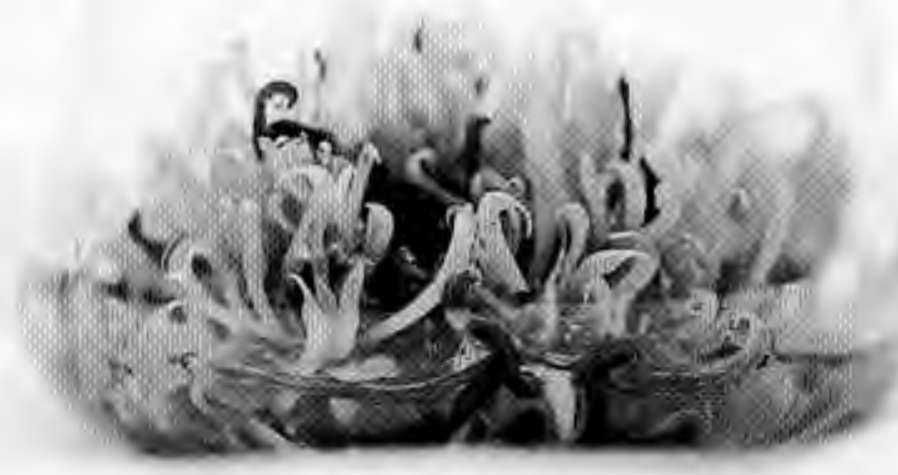


Figure 4. D. californica in liquid medium

A - Whole seedlings grown in liquid POMM without prior $\mathrm{GA}_{3}$ stimulation (X3.5)

B - Protocorm-like bodies and green callus formed on whole seedling grown in liquid POMM with prior $\mathrm{GA}_{3}$ stimulation (X7)

$\mathrm{C}-$ Seedlings grown in full-strength liquid MS medium for 30 days (X3) 

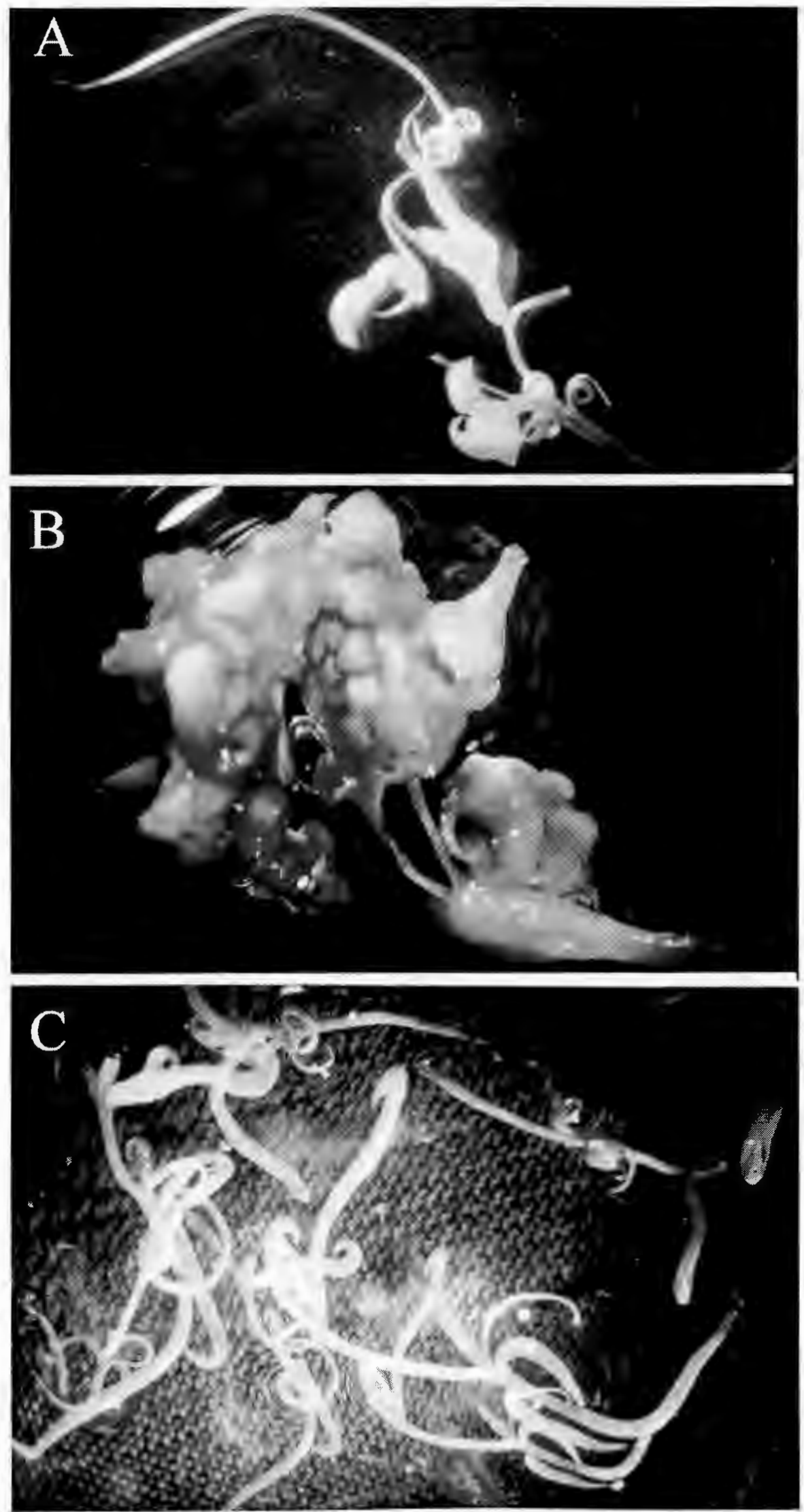
Figure 5. D. californica-Morphogenic structures produced from fragmented pitchers.
A - Flasks with shoots and protocorm-like bodies (X1.1)
B - Well-developed plantlet formed from pitcher fragment.
C - Small protocorm-like body separated from plantlet in Fig. 1A.
D - Protocorm-like body showing a cluster of small pitchers.
E - Protocorm-like body with large emerging leaf.

All drawings by Leslie Anne Uhnak. 

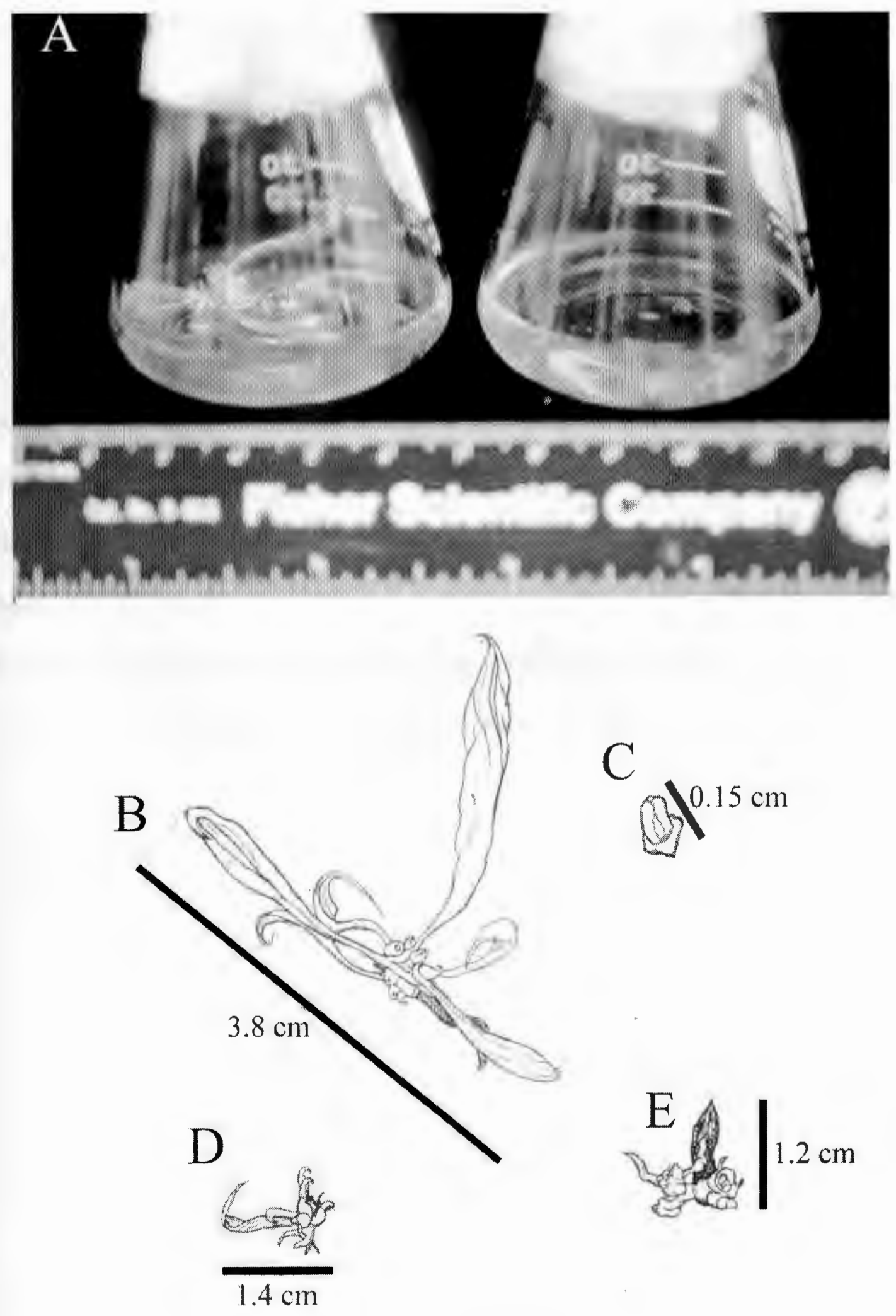
Figure 6. D. californica-Multiplication and growth of pitchers and protocorm-like bodies following subculture to liquid medium.

A - Multiplication of 6 clusters of pitchers after 45 days of subculture in liquid POMM (X1.0)

B - Protocorm-like bodies and callus produced from fragmented pitchers grown in liquid POMM (X1.3)

B inset - Small spherical body produced from pitcher fragment (X10)

C - Close-up of PLB in Fig. 6A(X 3.5) (compare to Fig. 1D). 

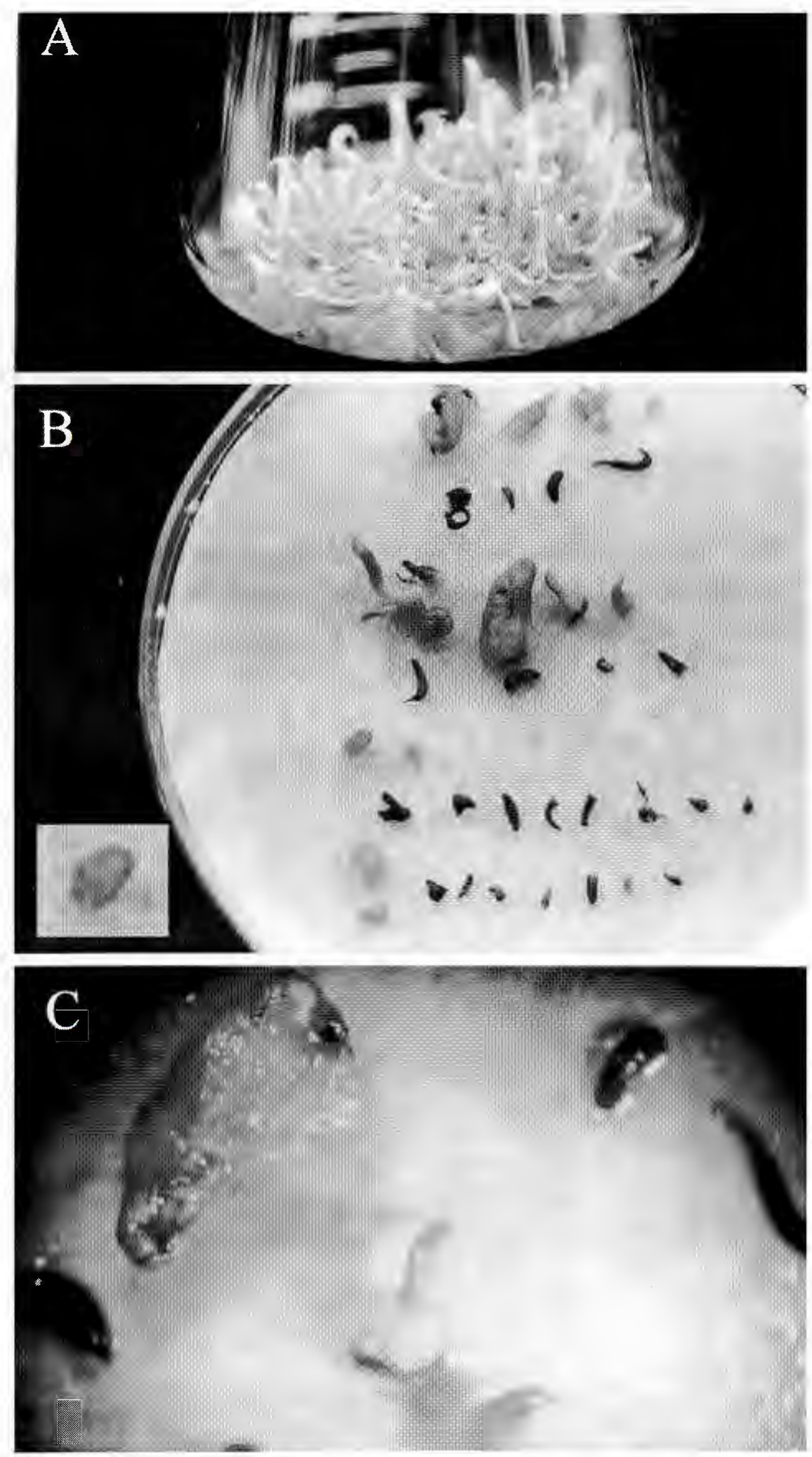
Figure 7. D. californica- New growth from whole and fragmented pitchers in liquid medium containing auxin and cytokinin.

A - Whole pitcher with new growth from tip after 30 days of subculture in liquid POMM (X4)

D - New growth from the distal end of a basal half of pitcher after 30 days of subculture in liquid POMM (X5) 

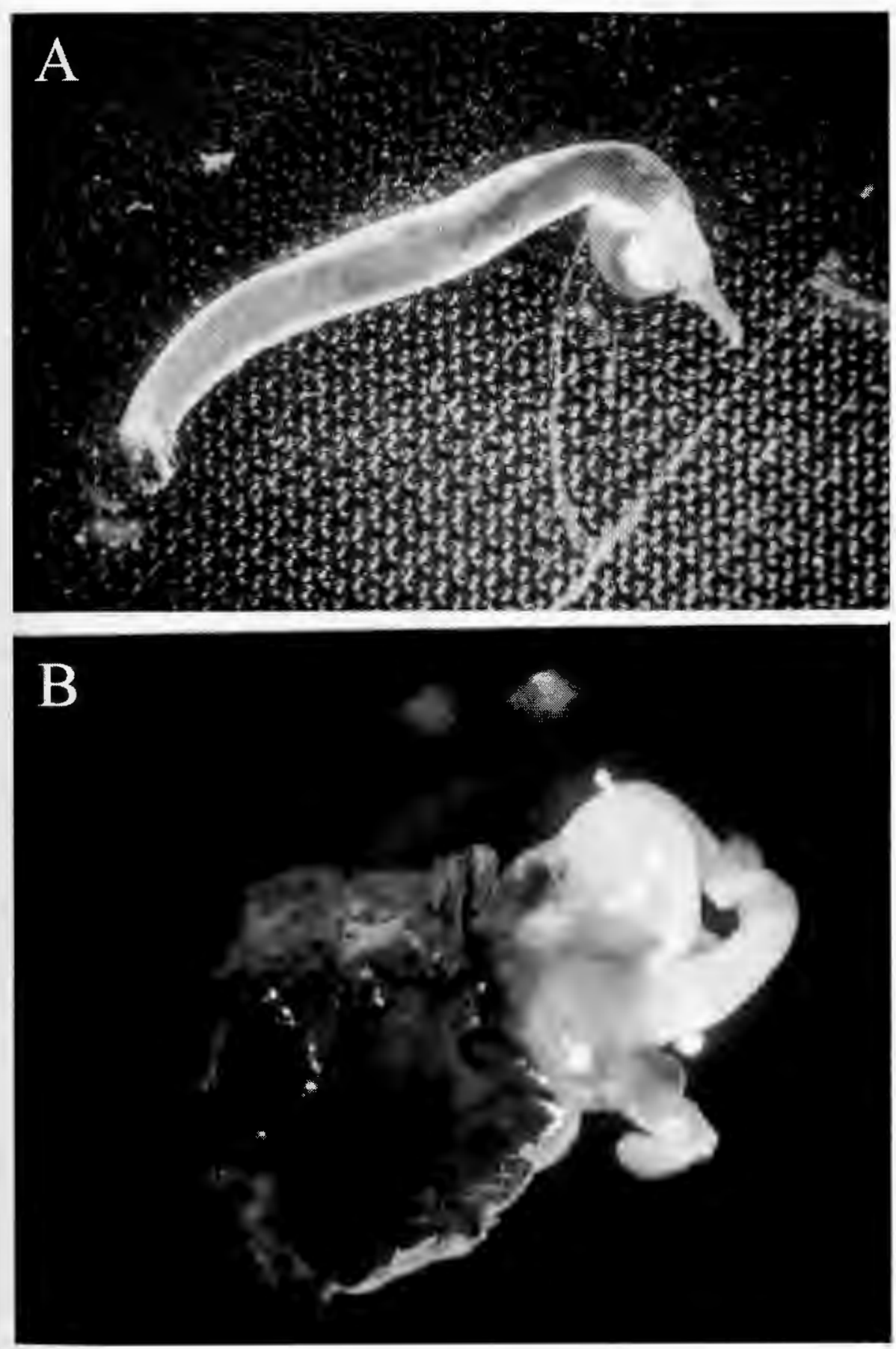
Figure 8. S. leucophylla-Seedlings, endosperm and embryos.

A-C - Seedlings of S. leucophylla after 6 months of subculture in vitro (Fig. 8A X0.7; Fig. 8B X0.9; Fig. 8C X0.8)

D - Two extracted embryos are shown along with a seed of S. leucophylla from which the seed coat has been removed to reveal yellow-white endosperm (X12) 
A

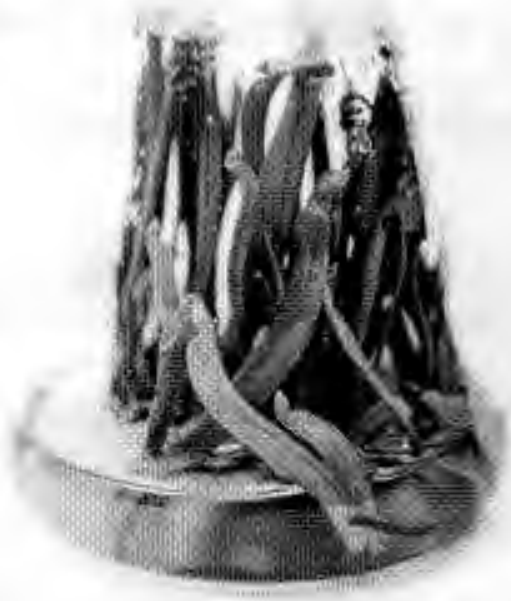

C

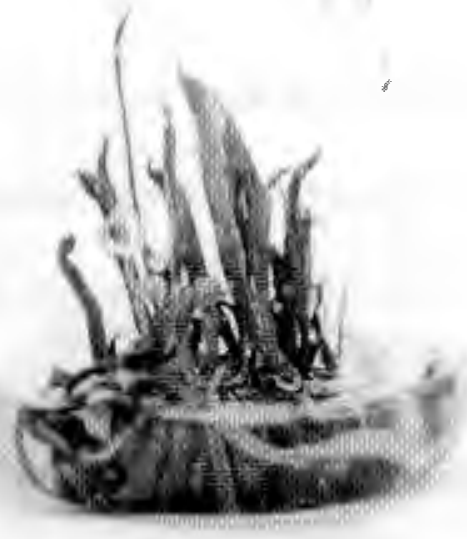

B

\&

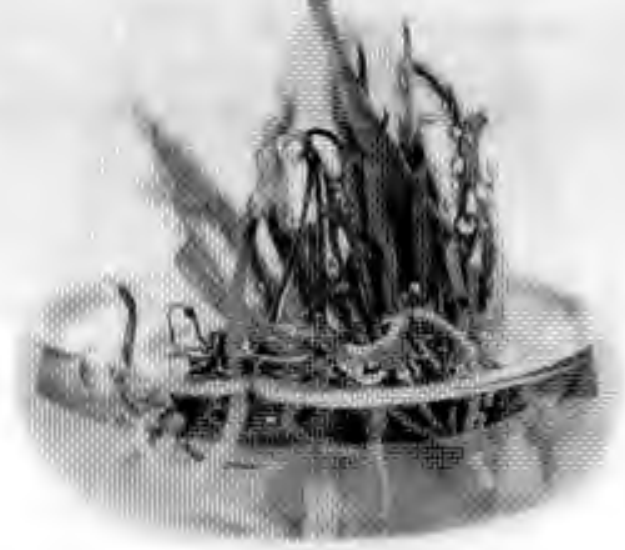

D

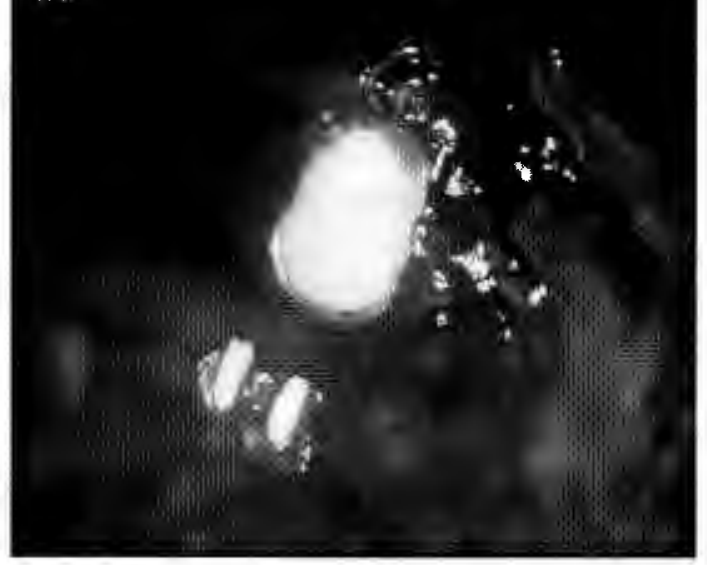




\section{Literature Cited}

Adamec L (1997) Mineral Nutrition of Carnivorous Plants: A Review. Bot. Rev. 63: 273-299

Adams II, R.M., Koenigsberg SS \& Langhans RW (1979) In vitro propagation of Cephalotus follicularis (Australian pitcher plant). HortScience 14(4): 512- 513

Cheers G (1992) A Guide to Carnivorous Plants of the World. New York. (pp. 60-61) Angus \& Robertson, Harper Collins Publishers. Australia

D'Amato P (1998) The Savage Garden. (pp.100-103) Ten Speed Press. Berkeley, CA

Franck DH (1975) Early histogenesis of the adult leaves of Darlingtonia californica (Sarraceniaceae) and its bearing on the nature of epiascidiate foliar appendages. Am. J. Bot. 62: 116-132

Franck DH (1976) Comparative morphology and early leaf histogenesis of adult and juvenile leaves of Darlingtonia californica and their bearing on the concept of heterophylly. Botanical Gazette, 137: 20-34

Givnish TJ (1989) Ecology and evolution of carnivorous plants. Plant-Animal Interactions. (pp. 243-290) McGraw-Hill Inc. New York. 
Godt MJW \& Hamrick JL (1996) Genetic structure of two endangered pitcher plants, Sarracenia jonseii and S. oreophila (Sarraceniaceae). Am. J. Bot. 83(8): 1016-1023

Hu CY \& Wang PJ (1983) Meristem, Shoot Tip and Bud Cultures. In: Handbook of Plant Cell Culture. (pp.177-227) Evans, D.A., Sharp, W.R., Ammirato, P.V \& Yasuyuki, Y. (eds) Macmillan Publishing Co., New York.

Kohlenbeck HW (1978) Comparative Somatic Morphogenesis. In Frontiers of Plant Tissue Culture. Thorpe TA (ed) Published by International Association for Plant Tissue Culture. Alberta, Canada

Lane WD (1979) The influence of growth regulators on root and shoot initiation from flax meristem tips and hypocotyles in vitro. Physiol. Plant. 45: 260-264

Lloyd EF (1942) The Carnivorous Plants. (pp.17-39) Chronica Botanica Co. Waltham, MA.

MacDougal DT (1903) The influence of light and darkness upon growth and development. Mem. New York Bot. Gard. 2: 1-319 
Malik KA \& Saxena PK (1991) Regeneration in Phaseolus vulgaris L.: High frequency induction of direct shoot formation in intact seedlings by $\mathrm{N}^{6}$ benzylaminopurine and thidiazuron. Planta 186: 384-389

Morel G (1974) Clonal Multiplication of Orchids. In: The Orchids, Scientific Studies. (pp. 169-222) Withner CL (ed) Wiley-Interscience, New York

Murashige T \& Skoog F (1962) A revised medium for rapid growth and bioassays with tobacco tissue culture. Physiol. Plant. 15: 473-497

Parliman BJ, Evans PT \& Rupert EA (1982a) Tissue culture of single rhizome explants of Dionaea muscipula Ellis ex. 1., the venus fly trap, for rapid asexual propagation. J. Am. Soc. Hort. Sci. 107 (2): 305-310

Parliman BJ, Evans PT \& Mazur AR (1982b) Adventitious bud differentiation and development in leaf cuttings of Dionaea muscipula Ellis ex. 1. (venus fly trap) cultured in vitro. J. Am. Soc. Hort. Sci. 107 (2): 310-316

Pietropaolo J \& Pietropaolo P. (1986) Carnivorous Plants of the World. (pp. 38-39) Timber Press. Portland, Oregon 
Rathore TS, Tandon P \& Shekhawat NS (1991) In vitro regeneration of pitcher plant (Nepenthes khasiana Hook. f.) - a rare insectivorous plant of India. J. Plant Physiol. 139: 246-248

Redwood G \& Bowling D (1990) Micropropagation of Nepenthes species. Bot. Gard. Microprop. News 1 (2): 19-20

Schnell DE (2002). Carnivorous Plants of the United States and Canada. (pp. 230233) Second Edition. Timber Press. Portland, Oregon

Teo WL, Kumar P, Goh C \& Swarup S 2001. The expression of Brostm, a KNOTTED1-like gene, marks the cell type and timing of in vitro shoot induction in Brassica oleracea. Plant Mol. Biol. 46: 567-580

Truscott FH (1966) Some aspect of morphogenesis in Cuscuta gronovii. Am. J. Bot. 53 (7): $739-750$

Walker DB (1975) Postgenital carpel fusion in Catharanthus roseus (Apocynaceae). I. Light and scanning electron microscopic study of gynoecial ontogeny. Am. J. Bot. 62(5): 457-467 


\section{APPENDIX A}

\section{RESULTS ANCILLARY TO MANUSCRIPT I}

Surface Disinfestation Study - Controls

\begin{tabular}{|c|c|}
\hline \multicolumn{2}{|c|}{$\begin{array}{c}\text { Darlingtonia californica - Sterile } \mathrm{H}_{2} \mathrm{O}+\text { Surfactant } \\
3 \times 5 \text { min washes in sterile distilled water }+1 \text { drop of Tween } 20 \\
\text { DCW } 1\end{array}$} \\
\begin{tabular}{c}
48 seeds - one seed per well in plastic well plates (MYP $+10 \mathrm{~g} / 1$ sucrose (pH 6.5) \\
\hline
\end{tabular} Sterile Wash \\
\hline $\begin{array}{c}\text { Contamination } \\
\text { after 15 days }\end{array}$ & $\begin{array}{c}17 \text { of } 48 \text { seeds contaminated by day } 15 \\
\text { (fungal mycelia present in all 17) }\end{array}$ \\
\hline
\end{tabular}

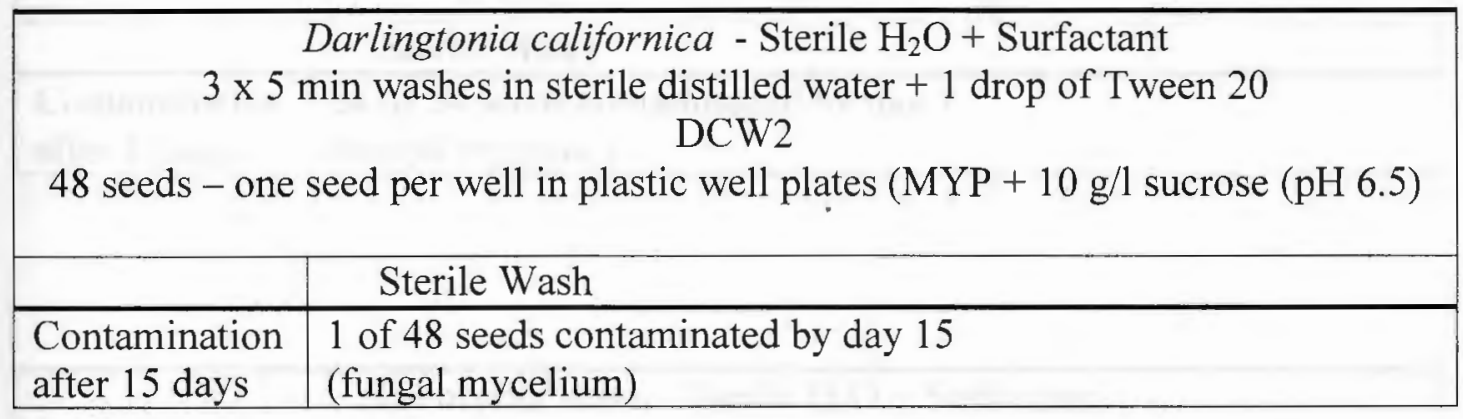

Sarracenia leucophylla- Sterile $\mathrm{H}_{2} \mathrm{O}+$ Surfactant

$3 \times 5$ min washes in sterile distilled water +1 drop of Tween 20

SLW1

48 seeds - one seed per well in plastic well plates (MYP $+10 \mathrm{~g} / 1$ sucrose $(\mathrm{pH} 6.5)$

\begin{tabular}{|l|l|}
\hline & Sterile Wash \\
\hline $\begin{array}{l}\text { Contamination } \\
\text { after 15 days }\end{array}$ & \begin{tabular}{l} 
(41 fungal mycelia, 7, yeast/bacterial) \\
\hline
\end{tabular} \\
\hline
\end{tabular}


Results of Surface Sterilization Experiments

\section{Darlingtonia californica 3\% Hydrogen Peroxide DCHP1}

48 seeds - one seed per well in plastic well plates (MYP $+10 \mathrm{~g} / \mathrm{l}$ sucrose $(\mathrm{pH} 6.5)$

\begin{tabular}{|l|l|l|l|l|}
\hline & $4 \mathrm{~min}$ & $8 \mathrm{~min}$ & $12 \mathrm{~min}$ & $16 \mathrm{~min}$ \\
\hline $\begin{array}{l}\text { Contamination } \\
\text { after 15 days }\end{array}$ & 0 of 48 & 0 of 48 & 0 of 48 & $\begin{array}{l}1 \text { of } 48 \\
(2.1 \%)\end{array}$ \\
\hline
\end{tabular}

\section{Darlingtonia californica 3\% Hydrogen Peroxide \\ DCHP2}

48 seeds - one seed per well in plastic well plates (MYP $+10 \mathrm{~g} / 1$ sucrose $(\mathrm{pH} 6.5)$

\begin{tabular}{|l|l|l|l|l|}
\hline & $4 \mathrm{~min}$ & $8 \mathrm{~min}$ & $12 \mathrm{~min}$ & $16 \mathrm{~min}$ \\
\hline $\begin{array}{l}\text { Contamination } \\
\text { after 15 days }\end{array}$ & 0 of 48 & 0 of 48 & 0 of 48 & 0 of 48 \\
\hline
\end{tabular}

Darlingtonia Californica Experiment \#DCCH1 and DCCH2 - 10\% Clorox + surfactant

\section{Darlingtonia californica $10 \%$ Clorox}

DCCH1

48 seeds - one seed per well in plastic well plates $(\mathrm{MYP}+10 \mathrm{~g} / 1$ sucrose $(\mathrm{pH} 6.5)$

\begin{tabular}{|l|l|l|l|l|}
\hline & $4 \mathrm{~min}$ & $8 \mathrm{~min}$ & $12 \mathrm{~min}$ & $16 \mathrm{~min}$ \\
\hline $\begin{array}{l}\text { Contamination } \\
\text { after 15 days }\end{array}$ & 0 of 48 & 0 of 48 & 0 of 48 & 0 of 48 \\
\hline
\end{tabular}

\section{Darlingtonia californica $10 \%$ Clorox}

$\mathrm{DCCH} 2$

48 seeds - one seed per well in plastic well plates (MYP $+10 \mathrm{~g} / 1$ sucrose $(\mathrm{pH}$ 6.5)

\begin{tabular}{|l|l|l|l|l|}
\hline & $4 \mathrm{~min}$ & $8 \mathrm{~min}$ & $12 \mathrm{~min}$ & $16 \mathrm{~min}$ \\
\hline $\begin{array}{l}\text { Contamination } \\
\text { after 15 days }\end{array}$ & 0 of 48 & 0 of 48 & 0 of 48 & 0 of 48 \\
\hline
\end{tabular}




\section{Darlingtonia californica - Concentrated $\mathrm{H}_{2} \mathrm{SO}_{4}$}

\section{DCCS1}

48 seeds - one seed per well in plastic well plates (MYP $+10 \mathrm{~g} / 1$ sucrose $(\mathrm{pH} 6.5)$

\begin{tabular}{|l|l|l|l|l|}
\hline & $4 \mathrm{~min}$ & $8 \mathrm{~min}$ & $12 \mathrm{~min}$ & $16 \mathrm{~min}$ \\
\hline $\begin{array}{l}\text { Contamination } \\
\text { after 15 days }\end{array}$ & 0 of 48 & 0 of 48 & 0 of 48 & 0 of 48 \\
\hline
\end{tabular}

\section{Darlingtonia californica - Concentrated $\mathrm{H}_{2} \mathrm{SO}_{4}$ \\ DCCS2}

48 seeds - one seed per well in plastic well plates (MYP $+10 \mathrm{~g} / \mathrm{l}$ sucrose $(\mathrm{pH} 6.5)$

\begin{tabular}{|l|l|l|l|l|}
\hline & $4 \mathrm{~min}$ & $8 \mathrm{~min}$ & $12 \mathrm{~min}$ & $16 \mathrm{~min}$ \\
\hline $\begin{array}{l}\text { Contamination } \\
\text { after 15 days }\end{array}$ & 0 of 48 & 0 of 48 & 0 of 48 & 0 of 48 \\
\hline
\end{tabular}

\section{Darlingtonia californica $1.5 \%$ Physan 20}

\section{DCPhy 1}

48 seeds - one seed per well in plastic well plates (MYP $+10 \mathrm{~g} / \mathrm{l}$ sucrose $(\mathrm{pH} 6.5)$

\begin{tabular}{|l|l|l|l|l|}
\hline & $4 \mathrm{~min}$ & $8 \mathrm{~min}$ & $12 \mathrm{~min}$ & $16 \mathrm{~min}$ \\
\hline $\begin{array}{l}\text { Contamination } \\
\text { after 15 days }\end{array}$ & 0 of 48 & 0 of 48 & 0 of 48 & 0 of 48 \\
\hline
\end{tabular}

\section{Darlingtonia californica $1.5 \%$ Physan 20}

\section{DCPhy2}

48 seeds - one seed per well in plastic well plates (MYP $+10 \mathrm{~g} / \mathrm{l}$ sucrose $(\mathrm{pH} 6.5)$

\begin{tabular}{|l|l|l|l|l|}
\hline & $4 \mathrm{~min}$ & $8 \mathrm{~min}$ & $12 \mathrm{~min}$ & $16 \mathrm{~min}$ \\
\hline $\begin{array}{l}\text { Contamination } \\
\text { after 15 days }\end{array}$ & 0 of 48 & 0 of 48 & 0 of 48 & 0 of 48 \\
\hline
\end{tabular}




\begin{tabular}{|c|c|c|c|c|}
\hline 48 seeds - one & $\begin{array}{l}\text { Sarracer } \\
\text { seed per } \mathrm{v}\end{array}$ & $\begin{array}{r}\text { phylla } 3 \% \\
\text { SLHP1 } \\
\text { astic well }\end{array}$ & Sen Peroxi & se $(\mathrm{pH} 6.5)$ \\
\hline & $4 \min$ & $8 \min$ & $12 \min$ & $16 \mathrm{~min}$ \\
\hline $\begin{array}{l}\text { Contamination } \\
\text { after } 15 \text { days }\end{array}$ & $\begin{array}{l}31 \text { of } 48 \\
(65.0 \%)\end{array}$ & $\begin{array}{l}48 \text { of } 48 \\
\text { by day } 6\end{array}$ & $\begin{array}{l}24 \text { of } 48 \\
(50.0 \%)\end{array}$ & $\begin{array}{l}21 \text { of } 48 \\
(44.0 \%)\end{array}$ \\
\hline
\end{tabular}

\begin{tabular}{|c|c|c|c|c|}
\hline \multicolumn{5}{|c|}{$\begin{array}{c}\text { Sarracenia leucophylla } 10 \% \text { Clorox } \\
\text { SLCH1 } \\
48 \text { seeds - one seed per well in plastic well plates (MYP }+10 \mathrm{~g} / \mathrm{l} \text { sucrose }(\mathrm{pH} 6.5)\end{array}$} \\
\hline & $4 \min$ & $8 \mathrm{~min}$ & $12 \mathrm{~min}$ & $16 \mathrm{~min}$ \\
\hline $\begin{array}{l}\text { Contamination } \\
\text { after } 15 \text { days }\end{array}$ & $\begin{array}{l}8 \text { of } 48 \\
(17.0 \%)\end{array}$ & $\begin{array}{l}4 \text { of } 48 \\
(8.3 \%)\end{array}$ & $\begin{array}{l}45 \text { of } 48 \\
(93.0 \%)\end{array}$ & $\begin{array}{l}4 \text { of } 48 \\
(8.3 \%)\end{array}$ \\
\hline
\end{tabular}

\begin{tabular}{|c|c|c|c|c|}
\hline \multicolumn{5}{|c|}{$\begin{array}{c}\text { Sarracenia leucophylla - Concentrated } \mathrm{H}_{2} \mathrm{SO}_{4} \\
\text { SLCS1 } \\
48 \text { seeds - one seed per well in plastic well plates (MYP }+10 \mathrm{~g} / 1 \text { sucrose }(\mathrm{pH} 6.5)\end{array}$} \\
\hline & $4 \mathrm{~min}$ & $8 \mathrm{~min}$ & $12 \mathrm{~min}$ & $16 \mathrm{~min}$ \\
\hline $\begin{array}{l}\text { Contamination } \\
\text { after } 15 \text { days }\end{array}$ & $\begin{array}{l}25 \text { of } 48 \\
(52.1 \%)\end{array}$ & $\begin{array}{l}19 \text { of } 48 \\
(40.0 \%)\end{array}$ & \begin{tabular}{|l|}
7 of 48 \\
$(14.6 \%)$
\end{tabular} & $\begin{array}{l}3 \text { of } 48 \\
(6.3 \%)\end{array}$ \\
\hline
\end{tabular}

\begin{tabular}{|c|c|c|c|c|}
\hline \multicolumn{5}{|c|}{$\begin{array}{l}\text { Sarracenia leucophylla }- \text { Concentrated } \mathrm{H}_{2} \mathrm{SO}_{4} \\
\text { SLCS2 } \\
48 \text { seeds - one seed per well in plastic well plates (MYP }+10 \mathrm{~g} / 1 \text { sucrose }(\mathrm{pH} 6.5)\end{array}$} \\
\hline & $4 \mathrm{~min}$ & $8 \mathrm{~min}$ & $12 \mathrm{~min}$ & $16 \mathrm{~min}$ \\
\hline $\begin{array}{l}\text { Contamination } \\
\text { after } 15 \text { days }\end{array}$ & $\begin{array}{l}27 \text { of } 48 \\
(56.3 \%)\end{array}$ & $\begin{array}{l}22 \text { of } 48 \\
(45.8 \%)\end{array}$ & $\begin{array}{l}12 \text { of } 48 \\
(25 \%)\end{array}$ & $\begin{array}{l}5 \text { of } 48 \\
(10.4 \%)\end{array}$ \\
\hline
\end{tabular}




\begin{tabular}{|c|c|c|c|c|}
\hline \multicolumn{5}{|c|}{$\begin{array}{l}\text { Sarracenia leucophylla } 1.5 \% \text { Physan } 20 \\
\text { SLPhy } 1 \\
\text { per well in plastic well plates (MYP }+10\end{array}$} \\
\hline & $4 \mathrm{~min}$ & $8 \mathrm{~min}$ & $12 \mathrm{~min}$ & $16 \mathrm{~min}$ \\
\hline $\begin{array}{l}\text { Contamination } \\
\text { after } 15 \text { days }\end{array}$ & $\begin{array}{l}44 \text { of } 48 \\
(91.7 \%)\end{array}$ & $\begin{array}{l}33 \text { of } 48 \\
(68.8 \%)\end{array}$ & $\begin{array}{l}32 \text { of } 48 \\
(66.6 \%)\end{array}$ & $\begin{array}{l}30 \text { of } 48 \\
(62.5 \%)\end{array}$ \\
\hline
\end{tabular}


Liquid Germination Experiments - Sarracenia leucophylla

Sarracenia leucophylla Experiment SL21 Type of Experiment - Germination Disinfestation - 10 minutes in $\mathrm{H}_{2} \mathrm{SO}_{4}$-Treatments -6 seeds/flask, 6 flasks/treatment Temp and light - Room conditions

Water (ph. 5.0)
\begin{tabular}{|l|l|l|l|l|l|l|l|l|l|l|l|l|l|}
\hline $\begin{array}{c}\text { Flask } \\
\#\end{array}$ & 1 & 2 & 3 & 4 & 5 & 6 & & 1 & 2 & 3 & 4 & 5 & 6 \\
\hline Day & & & & & & & & & & & & & \\
\hline 10 & 1 & 1 & cont & - & - & 1 & & - & - & - & - & - & - \\
\hline 11 & 1 & & & - & - & & & - & - & - & - & - & \\
\hline 12 & 1 & 2 & & - & - & 2 & & - & - & - & - & - & - \\
\hline 13 & 1 & 2 & & - & - & 2 & & - & - & - & - & - & 1 \\
\hline 14 & 1 & 2 & & - & - & 2 & - & - & - & - & - & 1 \\
\hline 15 & 1 & cont & & - & - & 2 & - & - & - & - & - & 1 \\
\hline 16 & 1 & 2 & & - & - & 2 & - & & - & - & - & 1 \\
\hline 17 & 1 & 2 & & - & - & 2 & - & - & - & - & - & 1 \\
\hline 18 & & & & - & - & & - & - & - & - & - & \\
\hline 19 & 1 & 2 & & - & - & 2 & - & - & - & - & - & 1 \\
\hline 20 & 1 & 2 & & - & - & 2 & - & - & - & - & - & 1 \\
\hline 21 & 1 & 2 & & - & - & 2 & - & - & - & - & - & 1 \\
\hline 22 & 1 & 2 & & - & - & 2 & - & - & - & - & - & 1 \\
\hline 23 & 1 & 2 & & - & - & 2 & - & - & - & - & - & 1 \\
\hline
\end{tabular}

Total germinated $=3$ of $24=12.5 \%$

Total Germinated $=1$ of $36=2.7 \%$

Results of Experiment \# SL1R1 Sarracenia leucophylla - Type of ExperimentGermination - seeds not stratified - 20 minutes in 10\% Clorox - 6 seeds/flask -6 flasks/treatment $50 \mathrm{ml}$ Erlenmeyer on gyrotary shaker - room light and temperature conditions - Start date 2/28/02.

Medium - Water (pH 5.0)

\begin{tabular}{|l|l|l|l|l|l|l|}
\hline Flask \# & \multicolumn{1}{|c|}{1} & 2 & 3 & 4 & 5 & 6 \\
\hline Day & $*$ & $*$ & $*$ & & $*$ & $*$ \\
\hline 15 & & 2 & & 2 & & \\
\hline 16 & 1 & 2 & & 2 & & 2 \\
\hline 17 & 1 & 2 & 1 & 3 & 1 & 2 \\
\hline 18 & & & & & & \\
\hline 19 & & & & & & \\
\hline 20 & & & & & & \\
\hline 21 & 1 & 2 & 1 & 3 & 1 & 2 \\
\hline
\end{tabular}

Total germinated $=3$ of $6=50 \%$ 
Results of Experiment \# SL2R1 Sarracenia leucophylla - Germination - seeds not stratified - 10 minutes in concentrated $\mathrm{H}_{2} \mathrm{SO}_{4}-6$ seeds/flask -6 flasks/treatment 50 $\mathrm{ml}$ Erlenmeyer on gyrotary shaker - room light and temperature conditions - Start date 2/02/02 (Note: Flasks 1, 4, and 7 contained 7 seeds.)

\begin{tabular}{|l|l|l|l|l|l|l|}
\hline Flask \# & 1 & 2 & 3 & 4 & 5 & 6 \\
\hline Day & $*$ & $*$ & $*$ & $*$ & $*$ & \\
\hline 11 & 4 & 2 & 5 & 3 & 3 & 3 \\
\hline 12 & & & & & & \\
\hline 13 & 5 & 2 & 5 & 3 & 3 & 3 \\
\hline 14 & 5 & 2 & 5 & 3 & 3 & 6 \\
\hline 15 & & & & & & \\
\hline 16 & & & & & & \\
\hline 17 & & & & & & \\
\hline 18 & & & & & & \\
\hline 19 & & & & & & \\
\hline 20 & & & & & & \\
\hline 21 & 5 & 2 & 5 & 3 & 3 & 6 of 7 \\
\hline
\end{tabular}

Medium - Water (pH. 5.0)

Total germinated $=6$ of $7=85.7 \%$

* = contamination 
Sarracenia leucophylla - Seed Selection Experiments - When seeds obtained from a commercial source were inspected with the aid of a dissecting microscope they could be divided into four categories; 1) Normal or non-suspect seeds - these seeds exhibit normal morphology, light brown color, outer coat heavily waxed, and no surface detectable imperfections; 2) Infected seeds - these seeds exhibit large areas of seed coat covered by a colored mass, usually gray, green, yellow or orange red, that appears to be tightly adhering fungal hyphae or sporulating structures. They may also have small holes in the seed coat; 3) Suspect seeds - these seeds appear to be normal as far as their general appearance, however on closer inspection, some cells of the outer seed coat may appear black or discolored. These areas may comprise several cells in diameter and can go undetected if the seed is not carefully examined; 4) Abnormal seeds - these seeds present abnormal developmental morphology and they may be very small, round, cup shaped or they can be elongate and narrow. Seeds were divided into the four categories and 20 seeds from each category were weighed.

\begin{tabular}{|l|l|l|l|l|}
\hline & Normal & Infected & Suspect & Abnormal \\
\hline $\begin{array}{l}\text { Weight of } 20 \\
\text { seeds }\end{array}$ & $0.0170 \mathrm{~g}$ & $0.0134 \mathrm{~g}$ & $0.0149 \mathrm{~g}$ & $0.0010 \mathrm{~g}$ \\
\hline $\begin{array}{l}\text { Average } \\
\text { weight of } 1 \\
\text { seed }\end{array}$ & $0.00085 \mathrm{~g}$ & $0.00067 \mathrm{~g}$ & 0.000745 & $0.00005 \mathrm{~g}$ \\
\hline
\end{tabular}

Results of Experiment \# SL1R2 - Germination - Sarracenia leucophylla - seeds not stratified - 10 minutes in concentrated $\mathrm{H}_{2} \mathrm{SO}_{4}$ with frequent mixing on vortex mixer and gentle agitation with tip of Pasteur pipet $-\mathrm{H}_{2} \mathrm{O}_{2}$ rinse on vortex mixer- rinsed in sterile $\mathrm{H}_{2} \mathrm{O}$ - solid and liquid treatments - liquid treatments in $50 \mathrm{ml}$ Erlenmeyer flasks -6 flasks- 6 seeds per flask -on gyrotary shaker at room temp and light. Solid treatment in $250 \mathrm{ml}$ Erlenmeyer flasks - 3 flasks - 12 seeds/flask - room temperature and light. Start date $4 / 10 / 02$.

Treatment $\# 1-75 \mathrm{ml}$ of solid $1 / 2$ strength MS medium + vitamins

\begin{tabular}{|l|l|l|}
\hline Flask \# 1 & Flask \# 2 & Flask \# 3 \\
\hline $\begin{array}{l}\text { 1 seed contaminated on } \\
\text { day 11 }\end{array}$ & $\begin{array}{l}\text { 1 seed contaminated on } \\
\text { day 5 }\end{array}$ & $\begin{array}{l}\text { 1 seed contaminated on } \\
\text { day 11 }\end{array}$ \\
\hline $\begin{array}{l}\text { No germination after 21 } \\
\text { days }\end{array}$ & $\begin{array}{l}\text { No germination after 21 } \\
\text { days }\end{array}$ & $\begin{array}{l}\text { No germination after 21 } \\
\text { days }\end{array}$ \\
\hline
\end{tabular}


Results of Experiment \# DC1R1 Darlingtonia californica - Type of ExperimentGermination - seeds not stratified - 10 minutes in 10\% Clorox - 6 seeds/flask -6 flasks/treatment $50 \mathrm{ml}$ Erlenmeyer - on gyrotary shaker - room light and temperature conditions - Start Date 2/28/02

Medium - Water (pH 5.0)

\begin{tabular}{|l|l|l|l|l|l|l|}
\hline Flask \# & 1 & 2 & 3 & 4 & 5 & 6 \\
\hline Day & & & & & & \\
\hline 16 & 4 & 4 & 4 & 4 & 4 & 6 \\
\hline 17 & 5 & 6 & 6 & 5 & 6 & 6 \\
\hline 18 & 5 & 6 & 6 & 5 & 6 & 6 \\
\hline 19 & & & & & & \\
\hline 20 & & & & & & \\
\hline 21 & 5 & 6 & 6 & 5 & 6 & 6 \\
\hline
\end{tabular}

Total germinated $=34$ of $36=94.4 \%$ 
Results of Experiment \# DCCUTT \#1 Darlingtonia californica - Germination - seeds not stratified - 10 minutes in $\mathrm{H}_{2} \mathrm{O}_{2}-30$ seeds were cut across the micropylar end and the distal portion removed - seeds were plated on water agar $(\mathrm{pH} 5.0)$ in a petri dish room light and temperature conditions - Start Date 5/2/02

\begin{tabular}{|c|c|c|}
\hline Day & \# of Seeds Germinated & Percent Germination \\
\hline 13 & 15 & $50 \%$ \\
\hline 14 & 18 & \\
\hline 15 & & $60 \%$ \\
\hline 16 & 20 & $66.6 \%$ \\
\hline 17 & 21 & \\
\hline 18 & & $70 \%$ \\
\hline 19 & 23 & $76.7 \%$ \\
\hline 21 & & \\
\hline
\end{tabular}

Germination $=76.7 \%$ in 21 days - Germination began on day 13

Results of Experiment \# DCCUTT \#2 Darlingtonia californica - Type of Experiment Germination - seeds not stratified - 10 minutes in $\mathrm{H}_{2} \mathrm{O}_{2}-30$ seeds were cut across the micropylar end and the distal portion removed - seeds were plated on water agar $(\mathrm{pH}$ 5.0) in a petri dish - room light and temperature conditions - Start Date 5/2/02

\begin{tabular}{|c|c|c|}
\hline Day & \# of Seeds Germinated & Percent Germination \\
\hline 13 & 15 & $50 \%$ \\
\hline 14 & 18 & \\
\hline 15 & & $60 \%$ \\
\hline 16 & 20 & $66.6 \%$ \\
\hline 17 & & \\
\hline 18 & 21 & $70 \%$ \\
\hline 19 & & \\
\hline 20 & 23 & $76.7 \%$ \\
\hline 21 & & \\
\hline
\end{tabular}

Germination $=76.7 \%$ in 21 days - Germination began on day 13 
Results of Experiment DCGEM2002 - Seeds used in this experiment were given three different treatments before plating on three different substrates. One hundred and twenty seeds of $D$. californica were removed from storage at $4-7^{\circ} \mathrm{C}$ and surface sterilized. Seeds were soaked overnight in $10 \mathrm{ml}$ of sterile distilled $\mathrm{H}_{2} \mathrm{O}$ (pH.5.0) +1 drop of Tween 20 at $4-7^{\circ} \mathrm{C}$.

Another 120 seeds were soaked under the same conditions except the $\mathrm{H}_{2} \mathrm{O}$ solution contained $6 \mathrm{mg} / \mathrm{l} \mathrm{GA}$. Surface disinfestation was in $3 \% \mathrm{H}_{2} \mathrm{O}_{2}$ for 10 minutes for all seeds. Seeds were not rinsed before being plated onto petri dishes containing - water agar ( $\mathrm{pH} 5.0$ ) - wet filter paper ( $\mathrm{pH} 5.0$ ) - filter paper wet with $\mathrm{H}_{2} \mathrm{O}$ containing $6 \mathrm{mg} / \mathrm{l}$ $\mathrm{GA}_{3}$. - 36 seeds/petri dish. Start date - May 1, 2002.

Treatment 1 - Seeds not soaked

\begin{tabular}{|l|l|l|l|}
\hline Day & $\begin{array}{c}\text { Treatment } \\
\text { Water agar }(\mathrm{pH} 5.0)\end{array}$ & $\begin{array}{c}\text { Treatment } \\
\text { Wet filter paper }(\mathrm{pH} \mathrm{5.0)}\end{array}$ & $\begin{array}{c}\text { Wet filter paper +6 mg/l } \\
\mathrm{GA}_{3}\end{array}$ \\
\hline 10 & & & \\
\hline 11 & & & \\
\hline 12 & & & 0 \\
\hline 13 & 4 & 0 & \\
\hline 14 & & & 0 \\
\hline 15 & 18 & 0 & 2 \\
\hline 16 & & & \\
\hline 17 & 25 & 0 & 2 \\
\hline 18 & & & \\
\hline 19 & 30 & 0 & 2 \\
\hline 20 & & & $5.5 \%$ germination \\
\hline 21 & 31 & 0 & \\
\hline & $86.1 \%$ germination & $0 \%$ germination & \\
\hline
\end{tabular}

Treatment 2 - Seeds soaked overnight in $\mathrm{H}_{2} \mathrm{O}+$ surfactant

\begin{tabular}{|l|l|l|l|}
\hline Day & $\begin{array}{c}\text { Treatment } \\
\text { Water agar (pH 5.0) }\end{array}$ & $\begin{array}{c}\text { Treatment } \\
\text { Wet filter paper }(\mathrm{pH} 5.0)\end{array}$ & $\begin{array}{c}\text { Wet filter paper +6 mg/l } \\
\mathrm{GA}_{3}\end{array}$ \\
\hline 10 & & & \\
\hline 11 & & & \\
\hline 12 & & & 0 \\
\hline 13 & 21 & 0 & \\
\hline 14 & & 0 & 0 \\
\hline 15 & 26 & & \\
\hline 16 & & 1 & 0 \\
\hline 17 & 28 & & \\
\hline 18 & & 1 & 2 \\
\hline 19 & 29 & & \\
\hline 20 & & 1 & $5.5 \%$ germination \\
\hline 21 & 30 & $2.8 \%$ germination & \\
\hline & $83.3 \%$ germination & & \\
\hline
\end{tabular}


Treatment 3 - Seeds soaked overnight in $\mathrm{H}_{2} \mathrm{O}+$ surfactant $+6 \mathrm{mg} / \mathrm{l} \mathrm{GA} 3$

\begin{tabular}{|l|l|l|l|}
\hline Day & $\begin{array}{c}\text { Treatment } \\
\text { Water agar (pH 5.0) }\end{array}$ & $\begin{array}{c}\text { Treatment } \\
\text { Wet filter paper }(\mathrm{pH} \\
5.0)\end{array}$ & $\begin{array}{c}\text { Wet filter paper +6 } \\
\mathrm{mg}^{\prime} \text { GA }\end{array}$ \\
\hline 10 & 7 & & 1 \\
\hline 11 & & & \\
\hline 12 & & & 2 \\
\hline 13 & 18 & 0 & 7 \\
\hline 14 & & & \\
\hline 15 & 20 & 0 & 9 \\
\hline 16 & & & \\
\hline 17 & 27 & 1 & 10 \\
\hline 18 & & & \\
\hline 19 & 31 & 2 & 10 \\
\hline 20 & & & $27.8 \%$ germination \\
\hline 21 & 32 & 2 & \\
\hline & $88.9 \%$ germination & $2.8 \%$ germination & \\
\hline
\end{tabular}

Darlingtonia californica - Seed weights from a batch obtained in February 2002, which showed good germination. Batch was weighed immediately after removal from storage at $4-7^{\circ} \mathrm{C}$.

February Batch

\begin{tabular}{|c|c|c|}
\hline & Weight of 12 seeds & Weight of 24 seeds \\
\hline 1 & $0.0022 \mathrm{~g}$ & $0.0039 \mathrm{~g}$ \\
\hline 2 & $0.0021 \mathrm{~g}$ & $0.0043 \mathrm{~g}$ \\
\hline 3 & $0.0022 \mathrm{~g}$ & $0.0044 \mathrm{~g}$ \\
\hline 4 & $0.0018 \mathrm{~g}$ & $0.0041 \mathrm{~g}$ \\
\hline 5 & $0.0020 \mathrm{~g}$ & $0.0040 \mathrm{~g}$ \\
\hline 6 & $0.0020 \mathrm{~g}$ & $0.0046 \mathrm{~g}$ \\
\hline 7 & $0.0022 \mathrm{~g}$ & $0.0042 \mathrm{~g}$ \\
\hline 8 & $0.0023 \mathrm{~g}$ & $0.0043 \mathrm{~g}$ \\
\hline 9 & $0.0022 \mathrm{~g}$ & $0.0042 \mathrm{~g}$ \\
\hline 10 & $0.0020 \mathrm{~g}$ & $0.0042 \mathrm{~g}$ \\
\hline & $\begin{array}{l}\text { Average weight } \\
\text { per seed }= \\
0.000175 \mathrm{~g}\end{array}$ & $\begin{array}{l}\text { Average weight of } \\
\text { each seed } \\
=0.000178 \mathrm{~g}\end{array}$ \\
\hline
\end{tabular}


Results of Experiment DC51 and DC52 - Darlingtonia californica

\begin{tabular}{|l|l|l|l|l|l|l|l|l|l|l|l|l|}
\hline Day & $\begin{array}{c}\text { Flask } \\
\# 1\end{array}$ & 2 & 3 & 4 & 5 & 6 & 1 & 2 & 3 & 4 & 5 & 6 \\
\hline 10 & 2 & 3 & 2 & 1 & 3 & 3 & & & $*$ & $*$ & 1 & 1 \\
\hline 11 & & & & & & & & & & & & \\
\hline 12 & 4 & 4 & 2 & 3 & 3 & 3 & & & & & 1 & 1 \\
\hline 13 & 5 & 4 & 3 & 3 & 4 & 4 & & & & & 1 & 1 \\
\hline 14 & 5 & 4 & 4 & 3 & 4 & 4 & & & & & 1 & 1 \\
\hline 15 & 6 & 4 & 4 & 3 & 4 & 4 & & & & & 1 & 1 \\
\hline 16 & 6 & 4 & 4 & 3 & 6 & 4 & & & & & 1 & 1 \\
\hline 17 & 6 & 4 & 4 & 3 & 6 & 4 & 1 & & & & 1 & 1 \\
\hline 18 & & & & & & & & & & & & \\
\hline 19 & 6 & 4 & 4 & 4 & 6 & 4 & 2 & & & & 1 & 2 \\
\hline 20 & 6 & 4 & 4 & 4 & 6 & 4 & 2 & & & & 1 & 2 \\
\hline 21 & 6 & 4 & 4 & 4 & 6 & 4 & 2 & 1 & 0 & 0 & 2 & 2 \\
\hline 28 of 36 seeds germinated in 21 days & $\begin{array}{l}6 \text { of 36 seeds germinated in } 21 \text { days } \\
\text { Germination }\end{array}$ \\
\hline
\end{tabular}

10 minutes $10 \%$ Clorox - 6 seeds/flask -6 x $50 \mathrm{ml}$ flasks - gyrotary shaker- room light and temp. Start date 4/10/02

Treatment \# $1 \mathrm{H}_{2} \mathrm{O} \quad$ DC52 Treatment \# 2 liquid $1 / 2$ strength MS

\begin{tabular}{|l|l|l|l|l|l|l|l|l|l|l|l|l|}
\hline Day & $\begin{array}{c}\text { Flask } \\
\# 1\end{array}$ & 2 & 3 & 4 & 5 & 6 & 1 & 2 & 3 & 4 & 5 & 6 \\
\hline 10 & 2 & 1 & 3 & 1 & 2 & 2 & & & 1 & & & 1 \\
\hline 11 & & & & & & & & & & & & \\
\hline 12 & 3 & 5 & 3 & 1 & 3 & 2 & & & 2 & & & 1 \\
\hline 13 & 4 & 5 & 4 & 2 & 3 & 2 & & & 2 & & & 1 \\
\hline 14 & 4 & 5 & 4 & 2 & 3 & 2 & & & 2 & & & 1 \\
\hline 15 & 5 & 5 & 4 & 2 & 3 & 2 & & & 2 & & 1 & 1 \\
\hline 16 & 5 & 5 & 4 & 2 & 3 & 2 & 2 & $*$ & 2 & 1 & 3 & 1 \\
\hline 17 & 5 & 5 & 4 & 2 & 4 & 3 & 2 & & 2 & 1 & 4 & 1 \\
\hline 18 & & & & & & & & & & & & \\
\hline 19 & 6 & 5 & 4 & 2 & 5 & 3 & 2 & & 3 & 2 & 4 & 1 \\
\hline 20 & 6 & 5 & 5 & 2 & 5 & 3 & 2 & & 3 & 2 & 4 & 1 \\
\hline 21 & 6 & 5 & 5 & 2 & 5 & 3 & 2 & & 3 & 2 & 4 & 1 \\
\hline 26 of 36 seeds germinated in 21 days \\
Germination
\end{tabular}

$*$ = contamination 
Results of The Dark Experiments - These experiments were conducted whenever more seeds than were needed for an experiment were surface sterilized. Excess seeds were plated on available media and placed in the dark at $27^{\circ} \mathrm{C}$ and observations made over various time periods.

Dark Experiment A1 - May 2, 2002 - Eighteen seeds of $D$. californica were treated overnight in $\mathrm{H}_{2} \mathrm{O}$ (pH.5.0) +1 drop of Tween 20 , surface sterilized for 10 min in $\mathrm{H}_{2} \mathrm{O}_{2}$, and plated on $\mathrm{H}_{2} \mathrm{O}$ agar (pH.5.0). No germination as of May 17, 2002 (15 days) however, seeds from experiment \# DCGEM2002 started on may 1 (room temp and light) had 50\% germination on May 15. No germination as of May 30, 2002. Seeds were next observed on June 15, 2002 and 3 seeds had germinated. This experiment was terminated on July 15,2002. A total of 9 seeds had germinated in 3 months.

Dark Experiment A3 - Excess seeds (22) from DC51 treatment \#1 were plated on water agar and stored in the dark at $27^{\circ} \mathrm{C}$. No germination as of day $22-2$ germinated on day 23.

Dark Experiment A3 - For purposes of an initial comparison with the above experiments, extra seeds $($ D. californica) from experiment \# DCGEM2002C were plated on water agar and placed in the growth chamber at $27^{\circ} \mathrm{C}$ with a 16 hour photoperiod.

Results:

\begin{tabular}{|l|l|l|l|}
\hline Day & $\begin{array}{l}\text { Treatment \#1 - not } \\
\text { stratified (44 seeds) }\end{array}$ & $\begin{array}{l}\text { Treatment } \# 2-24 \\
\text { hour soak in } \mathrm{H}_{2} \mathrm{O}(9 \\
\text { seeds })\end{array}$ & $\begin{array}{l}\text { Treatment \#3 }-24 \\
\text { hour soak in } \mathrm{H}_{2} \mathrm{O} \\
+\mathrm{GA}_{3}(37 \text { seeds })\end{array}$ \\
\hline 13 & 7 of 44 germinated & 4 of 9 germinated & 29 of 37 germinated \\
\hline 21 & 8 of 44 germinated & 5 of 9 germinated & 33 of 37 germinated \\
\hline
\end{tabular}


Germination Results from a Batch Received in Feb. 2002 - Darlingtonia californica

Results of Experiment DCGEM2002C - Germination (repeat of DCGEM2002) -

Water Agar (pH.5.0) - 3 pretreatments - Not stratified - $24 \mathrm{hr}$ soak in $\mathrm{H}_{2} \mathrm{O}-24$ soak in $\mathrm{GA}_{3}$ - surface sterilization in $\mathrm{H}_{2} \mathrm{O}_{2} 10$ min. - Batch from Feb $2002-25$ seeds per petri dish - Start Date - 7/23/02

\begin{tabular}{|c|c|c|c|c|c|c|}
\hline & \multicolumn{3}{|c|}{$\begin{array}{c}\text { Germination - not stratified - } \\
\text { water agar - pH 5.0 ( } 25 \text { seeds/plate })\end{array}$} & \multicolumn{3}{|c|}{$\begin{array}{c}\text { Germination following } 24 \mathrm{hr} \text { soak in } \\
\mathrm{H}_{2} \mathrm{O} \\
\text { water agar - pH } 5.0\end{array}$} \\
\hline Day & Plate \#1 & Plate \#2 & Plate\#3 & Plate \#1 & Plate \#2 & Plate \#3 \\
\hline 12 & 2 & 0 & 0 & $\overline{4}$ & 5 & 6 \\
\hline 13 & 4 & 1 & 1 & 5 & 7 & 8 \\
\hline 14 & 5 & 2 & 3 & 5 & 8 & 10 \\
\hline 15 & 5 & 3 & 4 & 6 & 9 & 10 \\
\hline \multicolumn{7}{|l|}{16} \\
\hline 17 & 6 & 4 & 4 & 6 & 10 & 10 \\
\hline \multicolumn{7}{|l|}{18} \\
\hline \multicolumn{7}{|l|}{19} \\
\hline 20 & 6 & 5 & 5 & 10 & 11 & 12 \\
\hline \multirow[t]{2}{*}{21} & 6 & 5 & 5 & 11 & 11 & 13 \\
\hline & \multicolumn{3}{|c|}{$\begin{array}{l}\text { Germination - } 16 \text { of } 75 \text { seeds after } \\
21 \text { days }\end{array}$} & \multicolumn{3}{|c|}{$\begin{array}{l}\text { Germination - } 35 \text { of } 75 \text { seeds after } \\
21 \text { days }\end{array}$} \\
\hline
\end{tabular}

\begin{tabular}{|l|l|l|l|}
\hline & \multicolumn{3}{|c|}{$\begin{array}{l}\text { Germination }-24 \text { hour soak in } \mathrm{GA}_{3} \\
\text { water agar }-\mathrm{pH} 5.0 \text { (25 seeds/plate) }\end{array}$} \\
\hline Day & Plate \#1 & Plate $\# 2$ & Plate \#3 \\
\hline 12 & 10 & 8 & 7 \\
\hline 13 & 12 & 12 & 8 \\
\hline 14 & 13 & 12 & 9 \\
\hline 15 & 14 & 13 & 9 \\
\hline 16 & & & \\
\hline & & & \\
\hline 17 & 16 & 15 & 11 \\
\hline 18 & & & \\
\hline 19 & & & \\
\hline 20 & 18 & 19 & 13 \\
\hline 21 & 20 & 19 & 17 \\
\hline & \multicolumn{3}{|l}{ Germination - 56 of 75 seeds after } \\
\hline
\end{tabular}


Germination Results from a Batch Received in Feb. 2002 - Darlingtonia californica

Results of Experiment DCGEM2002C - Germination (repeat of DCGEM2002) Water Agar (pH.5.0) - 3 pretreatments - Not stratified - 24 hr soak in $\mathrm{H}_{2} \mathrm{O}-24$ soak in $\mathrm{GA}_{3}$ - surface sterilization in $\mathrm{H}_{2} \mathrm{O}_{2} 10$ min. - Batch from Feb $2002-25$ seeds per petri dish - Start Date - 7/23/02

\begin{tabular}{|c|c|c|c|c|c|c|}
\hline \multirow[b]{2}{*}{ Day } & \multicolumn{3}{|c|}{$\begin{array}{c}\text { Germination - not stratified - } \\
\text { water agar - pH 5.0 ( } 25 \text { seeds/plate })\end{array}$} & \multicolumn{3}{|c|}{$\begin{array}{l}\text { Germination following } 24 \mathrm{hr} \text { soak in } \\
\qquad \mathrm{H}_{2} \mathrm{O} \\
\text { water agar }-\mathrm{pH} 5.0\end{array}$} \\
\hline & Plate \#1 & Plate \#2 & Plate\#3 & Plate \#1 & Plate \#2 & Plate \#3 \\
\hline 12 & 2 & 0 & 0 & 4 & 5 & 6 \\
\hline 13 & 4 & 1 & 1 & 5 & 7 & 8 \\
\hline 14 & 5 & 2 & 3 & 5 & 8 & 10 \\
\hline 15 & 5 & 3 & 4 & 6 & 9 & 10 \\
\hline \multicolumn{7}{|l|}{16} \\
\hline 17 & 6 & 4 & 4 & 6 & 10 & 10 \\
\hline \multicolumn{7}{|l|}{18} \\
\hline \multicolumn{7}{|l|}{19} \\
\hline 20 & 6 & 5 & 5 & 10 & 11 & 12 \\
\hline \multirow[t]{3}{*}{21} & 6 & 5 & 5 & 11 & 11 & 13 \\
\hline & \multirow{2}{*}{\multicolumn{3}{|c|}{$\begin{array}{l}\text { Germination - } 16 \text { of } 75 \text { seeds after } \\
21 \text { days }\end{array}$}} & & & \\
\hline & & & & \multicolumn{3}{|c|}{$\begin{array}{l}\text { Germination - } 35 \text { of } 75 \text { seeds after } \\
21 \text { days }\end{array}$} \\
\hline
\end{tabular}

\begin{tabular}{|l|l|l|l|}
\hline & \multicolumn{4}{|c|}{$\begin{array}{l}\text { Germination }-24 \text { hour soak in GA } \\
\text { water agar - pH 5.0 (25 seeds/plate) }\end{array}$} \\
\hline Day & Plate \#1 & Plate \#2 & Plate\#3 \\
\hline 12 & 10 & 8 & 7 \\
\hline 13 & 12 & 12 & 8 \\
\hline 14 & 13 & 12 & 9 \\
\hline 15 & 14 & 13 & 9 \\
\hline 16 & & & \\
\hline 17 & 16 & 15 & 11 \\
\hline 18 & & & \\
\hline 19 & & & \\
\hline 20 & 18 & 19 & 13 \\
\hline 21 & 20 & 19 & 17 \\
\hline & \multicolumn{3}{|l}{ Germination - 56 of 75 seeds after } \\
21 days
\end{tabular}


Germination Results from a Batch Received in June 2002 - Darlingtonia californica

Results of Experiment DCGEM2002B - Germination (seedlings for research) - Water Agar and sphagnum agar - $24 \mathrm{hr}$ soak $\mathrm{H}_{2} \mathrm{O}$ and also $\mathrm{GA}_{3}-\mathrm{H}_{2} \mathrm{O}_{2} 10$ min. - Batch from June 2002 - 40 seeds per petri dish - Start Date - 7/23/02 Data taken Sept. 8, 2002.

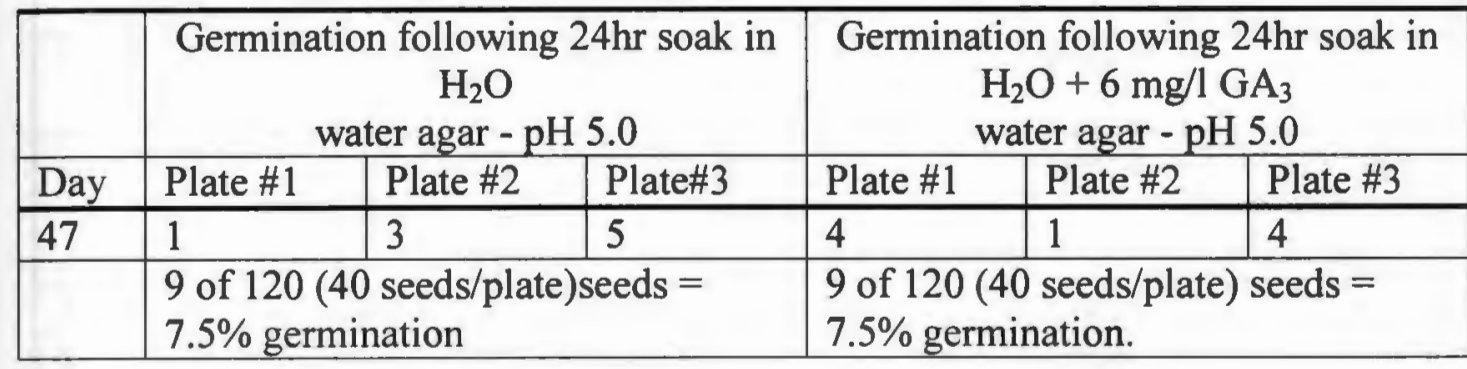

\begin{tabular}{|c|c|c|c|c|c|c|}
\hline & \multicolumn{3}{|c|}{$\begin{array}{c}\text { Germination following } 24 \mathrm{hr} \text { soak in } \\
\mathrm{H}_{2} \mathrm{O} \\
\text { Sphagnum based agar - pH } 5.0\end{array}$} & \multicolumn{3}{|c|}{$\begin{array}{c}\text { Germination following } 24 \mathrm{hr} \text { soak in } \\
\mathrm{H}_{2} \mathrm{O}+6 \mathrm{mg} / \mathrm{l} \mathrm{GA} 3 \\
\text { Sphagnum based agar - pH } 5.0\end{array}$} \\
\hline Day & Plate \#1 & Plate \#2 & Plate\#3 & Plate \#1 & Plate \#2 & Plate \#3 \\
\hline 47 & 0 & 0 & 0 & 0 & 0 & 0 \\
\hline & \multicolumn{3}{|c|}{$\begin{array}{l}0 \% \text { germination after } 47 \text { days ( } 120 \\
\text { seeds) }\end{array}$} & \multicolumn{3}{|c|}{$\begin{array}{l}0 \% \text { germination after } 47 \text { days ( } 120 \\
\text { seeds) }\end{array}$} \\
\hline
\end{tabular}

Results of Exp. GESD - Germination (seedlings for research) - Water agar - $24 \mathrm{hr}$ soak $\mathrm{H}_{2} \mathrm{O}-\mathrm{H}_{2} \mathrm{O}_{2} 10$ min. - room temp and light - Batch from June $2002-25$ seeds per petri dish - Start Date -8/1/02 Data taken Sept. 8, 2002.

\begin{tabular}{|l|l|l|l|l|l|l|l|l|}
\hline \multicolumn{7}{|c|}{ Germination following 24hr soak in $\mathrm{H}_{2} \mathrm{O}$} & - water agar $\mathrm{pH} 5.0$ \\
\hline $\begin{array}{l}\mathrm{D} \\
\text { ay }\end{array}$ & $\begin{array}{l}\text { Plate } \\
\# 1\end{array}$ & $\begin{array}{l}\text { Plate } \\
\# 2\end{array}$ & $\begin{array}{l}\text { Plate } \\
\# 3\end{array}$ & $\begin{array}{l}\text { Plate } \\
\# 4\end{array}$ & $\begin{array}{l}\text { Plate } \\
\# 5\end{array}$ & $\begin{array}{l}\text { Plate } \\
\# 6\end{array}$ & $\begin{array}{l}\text { Plate } \\
\# 7\end{array}$ & $\begin{array}{l}\text { Plate } \\
\# 8\end{array}$ \\
\hline $\begin{array}{l}3 \\
8\end{array}$ & 1 & 1 & 0 & 1 & 1 & 1 & 2 & 0 \\
\hline 7
\end{tabular}

Plates from GESD were placed in the growth chamber on $9 / 8 / 02$ 


\section{RESULTS ANCILLARY TO MANUSCRIPT II}

Results of Experiment M1R1 - Growth on solid 1/2 Strength MS Medium + Vitamins

\begin{tabular}{|c|c|c|c|c|c|}
\hline $\begin{array}{c}\text { Tube } \\
\#\end{array}$ & $\begin{array}{c}\text { No. } \\
\text { of } \\
\text { Pitchers }\end{array}$ & $\begin{array}{c}\text { Length of } \\
\text { Pitchers } \\
(\mathrm{mm})\end{array}$ & Roots & Color & Observations \\
\hline 1 & 6 & $\begin{array}{l}11,9,7,10 \\
, 8,8\end{array}$ & Primary & Green & \\
\hline 2 & 6 & $\begin{array}{l}10,10,11 \\
8,9,7\end{array}$ & Primary & Green & $\begin{array}{l}\text { Primary root } \\
\text { dichotomously } \\
\text { split at tip }\end{array}$ \\
\hline 3 & 5 & $8,8,6,5,7$ & Primary, 1 secondary & Green & \\
\hline 4 & 7 & $\begin{array}{l}12,11,11 \\
3,4,4,9\end{array}$ & Primary & Green & \\
\hline 5 & 5 & $6,8,7,4,3$ & Primary & Green & \\
\hline 6 & 6 & $\begin{array}{l}6,3,3,4,8 \\
7\end{array}$ & Primary & Green & \\
\hline 7 & 4 & $5,4,4,3$ & Primary & Green & \\
\hline 8 & 6 & $\begin{array}{l}10,10,9,4 \\
, 7,8\end{array}$ & $\begin{array}{l}\text { Primary, } 1 \text { early } \\
\text { secondary }\end{array}$ & Green & \\
\hline 9 & 7 & $\begin{array}{l}72,12,11 \\
7,4,9,8\end{array}$ & Primary & Green & $\begin{array}{l}\text { Primary very } \\
\text { well developed }\end{array}$ \\
\hline 10 & 5 & $6,5,2,3,8$ & Primary & & \\
\hline 11 & 6 & $\begin{array}{l}6,6,7,5,4, \\
3\end{array}$ & Primary & Green & \\
\hline 12 & 4 & $8,7,5,3$ & Primary & Green & \\
\hline 13 & 3 & $5,4,3$ & Primary & Green & \\
\hline 14 & 6 & $\begin{array}{l}3,3,4,7,6, \\
6\end{array}$ & Primary & Green & \\
\hline 15 & 6 & $\begin{array}{l}12.12 .11 \\
9.10,4\end{array}$ & $\begin{array}{l}\text { Primary, } 1 \text { well developed } \\
\text { secondary }\end{array}$ & Green & $\begin{array}{l}\text { Secondary } \\
\text { arising from } \\
\text { rhizome }\end{array}$ \\
\hline 16 & 5 & $6,5,5,4,3$ & 1 Primary & Green & \\
\hline 17 & 5 & $5,4,5,3,3$ & 1 Primary & Green & \\
\hline 18 & 6 & $\begin{array}{l}12,11,11 \\
9,7,5\end{array}$ & 1 Primary & Green & \\
\hline & & & & & \\
\hline
\end{tabular}

Total dry Mass $=0.0370$ 
Results of Experiment M1R1 - Growth on Solid Sphagnum-based Medium + Vitamins

\begin{tabular}{|l|l|l|l|l|l|}
\hline $\begin{array}{c}\text { Tube } \\
\#\end{array}$ & $\begin{array}{c}\text { No. } \\
\text { of } \\
\text { Pitchers }\end{array}$ & $\begin{array}{c}\text { Length of } \\
\text { Pitchers } \\
(\mathrm{mm})\end{array}$ & \multicolumn{1}{|c|}{ Roots } & \multicolumn{1}{|c|}{ Color } & Observations \\
\hline 1 & 3 & $4,3,3$ & Primary & Light green & \\
\hline 2 & 5 & $5,4,4,3,3$ & Primary & Light green & \\
\hline 3 & 3 & $4,3,3$ & Primary & Yellow & \\
\hline 4 & 5 & $5,6,4,3,3$ & Primary & Yellow Green & \\
\hline 5 & 4 & $5,5,4,3$ & Primary & Yellow & \\
\hline 6 & 5 & $5,3,3,3,4$ & Primary & Yellow green & \\
\hline 7 & 4 & $3,5,5,3$ & Primary & Yellow green & \\
\hline 8 & 56 & $5,5,4,4,6,3$ & $\begin{array}{l}\text { Primary with } \\
\text { secondary }\end{array}$ & Green & \\
\hline 9 & 2 & 4,3 & Primary & Yellow brown & $\begin{array}{l}\text { Stopped } \\
\text { development } \\
\text { appr. week 2 }\end{array}$ \\
\hline 10 & 5 & $6,5,4,4,4$ & Primary & Green & \\
\hline 11 & 2 & 3,3 & Primary & Yellow brown & $\begin{array}{l}\text { Stopped } \\
\text { development } \\
\text { appr. week 2 }\end{array}$ \\
\hline 12 & 2 & 3,4 & Primary & Yellow brown & \\
\hline 13 & 3 & $3,3,4$ & Primary & Yellow green & \\
\hline 14 & 6 & $6,6,5,4,4,3$ & Primary & Green & \\
\hline 15 & 4 & $4,3,3,3$ & Primary & Yellow green & \\
\hline 16 & 5 & $6,5,5,4,3$ & $\begin{array}{l}\text { Primary with } \\
\text { secondary }\end{array}$ & Green & \\
\hline 17 & 6 & $6,6,3,5,5$ & $\begin{array}{l}\text { Primary with } \\
\text { Bud }\end{array}$ & Yellow green & \\
\hline 18 & 5 & $5,4,4,3,3$ & Primary & Yellow green & \\
\hline & & & & & \\
\hline
\end{tabular}

Total dry Mass $=0.0195$

Results of Experiment M2R2 - Growth on Solid 1/2 Strength MS + Vitamins 
Results of Experiment M2R2 - Growth on Solid $1 / 2$ Strength MS + Vitamins

\begin{tabular}{|c|c|c|c|c|c|}
\hline $\begin{array}{c}\text { Tube } \\
\#\end{array}$ & $\begin{array}{c}\begin{array}{c}\text { No. } \\
\text { of } \\
\text { Pitchers }\end{array} \\
\end{array}$ & $\begin{array}{c}\text { Length of } \\
\text { Pitchers (mm) }\end{array}$ & Roots & Color & Observations \\
\hline 1 & 7 & $5,6,4,4,6,3,3$ & $\begin{array}{l}\text { Primary with } 1 \\
\text { bud }\end{array}$ & Green & \\
\hline 2 & 3 & $3,4,3$ & Primary & Brown & $\begin{array}{l}\text { Stopped } \\
\text { development } \\
\text { appr. week } 2\end{array}$ \\
\hline 3 & 8 & $5,6,6,5,4,4,5,4$ & $\begin{array}{l}\text { Primary with } 1 \\
\text { bud }\end{array}$ & Green & \\
\hline 4 & 9 & $9,8,8,7,8,6,5,5,4$ & $\begin{array}{l}\text { Primary with } 1 \\
\text { bud }\end{array}$ & Green & \\
\hline 5 & 9 & $\begin{array}{l}10,10,9,9,8,7,9 \\
6,5\end{array}$ & $\begin{array}{l}\text { Primary with } 2 \\
\text { buds }\end{array}$ & Green & \\
\hline 6 & 5 & $5,6,5,4,3$ & Primary & Green & \\
\hline 7 & 6 & $7,8,7,6,4,4$ & $\begin{array}{l}\text { Primary with } 1 \\
\text { bud }\end{array}$ & Green & \\
\hline 8 & 3 & $4,4,3$ & Primary & Green & \\
\hline 9 & 7 & $6,7,6,5,4,4,4$ & $\begin{array}{l}\text { Primary split } \\
\text { dichotomously } \\
\text { at tip }\end{array}$ & Green & \\
\hline 10 & 5 & $7,7,6,5,5$ & Primary & Green & \\
\hline 11 & 8 & $\begin{array}{l}12,13,12,10.9 .8 . \\
7.8\end{array}$ & $\begin{array}{l}\text { Primary with } 2 \\
\text { buds }\end{array}$ & Green & \\
\hline 12 & 8 & $9,8,8,7,6,5,7,8$ & $\begin{array}{l}\text { Primary with } 2 \\
\text { bud }\end{array}$ & Green & \\
\hline 13 & 5 & $6,5,5,4,4$ & Primary & Green & \\
\hline 14 & 3 & $4,5,3$ & Primary & $\begin{array}{l}\text { Yellow } \\
\text { brown }\end{array}$ & $\begin{array}{l}\text { Stopped } \\
\text { development } \\
\text { appr. week } 2\end{array}$ \\
\hline 15 & 5 & $5,4,6,6,5$ & $\begin{array}{l}\text { Primary with } 2 \\
\text { buds }\end{array}$ & Green & \\
\hline 16 & 5 & $5,4,4,4,3$ & $\begin{array}{l}\text { Primary with } 1 \\
\text { bud }\end{array}$ & Green & \\
\hline 17 & 6 & $10,8,8,7,8,5$ & $\begin{array}{l}\text { Primary with } 1 \\
\text { bud }\end{array}$ & Green & \\
\hline 18 & 7 & $11,9,9,8,7,7,6$ & $\begin{array}{l}\text { Primary with } 2 \\
\text { bud }\end{array}$ & Green & \\
\hline
\end{tabular}

Total dry Mass $=0.0763 \mathrm{~g}$ 
Results of Experiment M2R2 Growth on Burgeff's $\mathrm{N}_{3} f$ Medium + Vitamins

\begin{tabular}{|c|c|c|c|c|c|}
\hline $\begin{array}{c}\text { Tube } \\
\#\end{array}$ & $\begin{array}{c}\begin{array}{c}\text { No. } \\
\text { of } \\
\text { Pitchers }\end{array} \\
\end{array}$ & $\begin{array}{l}\text { Length of } \\
\text { Pitchers } \\
\text { (mm) }\end{array}$ & Roots & Color & Observations \\
\hline 1 & 3 & $4,4,3$ & Primary & $\begin{array}{l}\text { Yellow } \\
\text { brown }\end{array}$ & \\
\hline 2 & 2 & 3,3 & Primary & Brown & $\begin{array}{l}\text { Stopped } \\
\text { development } \\
\text { approx. week } \\
2\end{array}$ \\
\hline 3 & 2 & 2,4 & Primary & Brown & $\begin{array}{l}\text { Stopped } \\
\text { development } \\
\text { approx. week } \\
2\end{array}$ \\
\hline 4 & 3 & $4,5,4$ & Primary & $\begin{array}{l}\text { Yellow } \\
\text { Brown }\end{array}$ & \\
\hline 5 & 5 & $6,5,3,3,3$ & Primary & Yellow & \\
\hline 6 & 3 & $4,3,3$ & Primary & $\begin{array}{l}\text { Yellow } \\
\text { brown }\end{array}$ & \\
\hline 7 & 2 & 3,4 & Primary & Brown & \\
\hline 8 & 3 & $4,4,3$ & Primary & $\begin{array}{l}\text { Yellow } \\
\text { Brown }\end{array}$ & \\
\hline 9 & 4 & $4,4,3,3$ & Primary & $\begin{array}{l}\text { Yellow } \\
\text { green }\end{array}$ & \\
\hline 10 & 5 & $5,5,5,4,3$ & $\begin{array}{l}\text { Primary with } 1 \\
\text { bud }\end{array}$ & Yellow & \\
\hline 11 & 2 & 3,3 & Primary & $\begin{array}{l}\text { Yellow } \\
\text { brown }\end{array}$ & \\
\hline 12 & 1 & 3 & Primary & Brown & $\begin{array}{l}\text { Stopped } \\
\text { development } \\
\text { approx. week } \\
2\end{array}$ \\
\hline 13 & 2 & 3,3 & Primary & Brown & $\begin{array}{l}\text { Stopped } \\
\text { development } \\
\text { approx. week } \\
2\end{array}$ \\
\hline 14 & 3 & $4,3,3$ & Primary & Yellow & \\
\hline 15 & 5 & $6,6,5,4,4,3$ & $\begin{array}{l}\text { Primary with } 1 \\
\text { bud }\end{array}$ & $\begin{array}{l}\text { Yellow } \\
\text { green }\end{array}$ & \\
\hline 16 & 4 & $5,4,4,3$ & Primary & $\begin{array}{l}\text { Yellow } \\
\text { brown }\end{array}$ & \\
\hline 17 & 4 & $4,4,4,3$ & Primary & Brown & \\
\hline 18 & 5 & $6,5,5,4,4$ & Primary & $\begin{array}{l}\text { Yellow } \\
\text { green }\end{array}$ & \\
\hline
\end{tabular}

Total dry weight $=0.0187 \mathrm{~g}$ 
Results of Experiment M2R2 Growth on Sphagnum - based Medium + Vitamins

\begin{tabular}{|c|c|c|c|c|c|}
\hline $\begin{array}{c}\text { Tube } \\
\#\end{array}$ & $\begin{array}{c}\text { No } \\
\text { of } \\
\text { Pitcher } \\
s\end{array}$ & $\begin{array}{l}\text { Length } \\
\text { of } \\
\text { Pitcher } \\
\mathrm{s} \\
(\mathrm{mm})\end{array}$ & $\overline{\text { Roots }}$ & Color & Observations \\
\hline 1 & 3 & $4,3,3$ & Primary & Yellow green & \\
\hline 2 & 1 & 3 & Primary & Brown & $\begin{array}{l}\text { Stopped development } \\
\text { approx. week } 1\end{array}$ \\
\hline 3 & 1 & 3 & Primary & Brown & $\begin{array}{l}\text { Stopped development } \\
\text { approx. week } 1\end{array}$ \\
\hline 4 & 3 & $5,4,3$ & Primary & Yellow green & \\
\hline 5 & 4 & $4,5,5,3$ & $\begin{array}{l}\text { Primary with } 1 \\
\text { secondary }\end{array}$ & Yellow green & \\
\hline 6 & 5 & $\begin{array}{l}5,4,4,4 \\
, 3\end{array}$ & $\begin{array}{l}\text { Primary with } 1 \\
\text { secondary }\end{array}$ & Yellow green & \\
\hline 7 & 4 & $5,4,4,4$ & $\begin{array}{l}\text { Primary with } 1 \\
\text { secondary }\end{array}$ & Yellow green & \\
\hline 8 & 5 & $\begin{array}{l}5,5,4,4 \\
, 3 \\
\end{array}$ & $\begin{array}{l}\text { Primary with } 1 \\
\text { secondary }\end{array}$ & Green & \\
\hline 9 & 5 & $\begin{array}{l}6,5,5,4 \\
, 4\end{array}$ & $\begin{array}{l}\text { Primary with } 1 \\
\text { secondary }\end{array}$ & Green & \\
\hline 10 & 5 & $\begin{array}{l}4,5,5,3 \\
, 3\end{array}$ & $\begin{array}{l}\text { Primary with } 1 \\
\text { secondary }\end{array}$ & Green & \\
\hline 11 & 6 & $\begin{array}{l}6,6,5,4 \\
, 4,3\end{array}$ & $\begin{array}{l}\text { Primary with } 1 \\
\text { secondary }\end{array}$ & Green & \\
\hline 12 & 4 & $4,4,3,3$ & Primary & Yellow green & \\
\hline 13 & 5 & $\begin{array}{l}6,4,4,3 \\
, 3\end{array}$ & $\begin{array}{l}\text { Primary } \\
\text { dichotomously } \\
\text { branched }\end{array}$ & Yellow green & \\
\hline 14 & 2 & 3,3 & Primary & Brown yellow & $\begin{array}{l}\text { Stopped development } \\
\text { approx. week } 2\end{array}$ \\
\hline 15 & 1 & 3 & Primary & Brown & $\begin{array}{l}\text { Stopped development } \\
\text { approx. week } 1\end{array}$ \\
\hline 16 & 4 & $5,3,4,3$ & $\begin{array}{l}\text { Primary } \\
\text { dichotomously } \\
\text { branched }\end{array}$ & Yellow green & \\
\hline 17 & 6 & $\begin{array}{l}5,5,5,4 \\
, 4,3\end{array}$ & $\begin{array}{l}\text { Primary } \\
\text { dichotomously } \\
\text { branched }\end{array}$ & Green & \\
\hline 18 & 5 & $5,4,4,3$ & $\begin{array}{l}\text { Primary } \\
\text { dichotomously } \\
\text { branched }\end{array}$ & Yellow green & \\
\hline
\end{tabular}

Total Dry Mass $=0.0194 \mathrm{~g}$ 
Results of Experiment Root \# 1

\begin{tabular}{|c|c|c|c|c|c|c|}
\hline \multicolumn{7}{|c|}{$\begin{array}{l}\text { Experiment RT \# } 1 \text { - Treatment \# } 1 \\
\text { Liquid } 1 / 2 \text { Strength MS + Vitamins }\end{array}$} \\
\hline & \multicolumn{2}{|c|}{ Flask \# 1} & \multicolumn{2}{|c|}{ Flask \# 2} & \multicolumn{2}{|c|}{ Flask \# 3} \\
\hline & \multicolumn{2}{|c|}{ Total \# of pitchers $=196$} & \multicolumn{2}{|c|}{ Total \# of pitchers $=172$} & \multicolumn{2}{|c|}{$\begin{array}{l}\text { Total \# of pitchers = } \\
208\end{array}$} \\
\hline & $\begin{array}{l}\text { Length of } \\
\text { longest } 20 \\
\text { pitchers } \\
(\mathrm{cm})\end{array}$ & \multirow{26}{*}{\begin{tabular}{|l|} 
Roots \\
\\
\# of \\
Rhizome \\
segments \\
examined $=$ \\
17
\end{tabular}} & $\begin{array}{l}\text { Length of } \\
\text { longest } 20 \\
\text { pitchers } \\
(\mathrm{cm})\end{array}$ & \multirow{26}{*}{$\begin{array}{l}\text { Roots } \\
\text { \# of } \\
\text { Rhizome } \\
\text { segments } \\
\text { examined = } \\
17\end{array}$} & $\begin{array}{l}\text { Length of } \\
\text { longest } 20 \\
\text { pitchers } \\
(\mathrm{cm})\end{array}$ & \multirow{26}{*}{$\begin{array}{l}\text { Roots } \\
\text { \# of } \\
\text { Rhizome } \\
\text { segments } \\
\text { examined } \\
=17\end{array}$} \\
\hline 1 & 2.1 & & 3.1 & & 2.5 & \\
\hline 2 & 2.5 & & 2.8 & & 2.3 & \\
\hline 3 & 2.4 & & 2.5 & & 2.1 & \\
\hline 4 & 2.0 & & 2.0 & & 2.4 & \\
\hline 5 & 2.6 & & 2.3 & & 2.0 & \\
\hline 6 & 2.3 & & 2.4 & & 2.0 & \\
\hline 7 & 2.5 & & 2.1 & & 2.4 & \\
\hline 8 & 2.4 & & 2.3 & & 2.5 & \\
\hline 9 & 2.0 & & 2.4 & & 2.6 & \\
\hline 10 & 2.8 & & 2.4 & & 2.5 & \\
\hline 11 & 2.7 & & 2.0 & & 2.1 & \\
\hline 12 & 2.5 & & 2.0 & & 2.3 & \\
\hline 13 & 2.3 & & 1.8 & & 2.2 & \\
\hline 14 & 2.4 & & 2.0 & & 2.0 & \\
\hline 15 & 2.5 & & 2.3 & & 2.1 & \\
\hline 16 & 2.6 & & 2.4 & & 2.1 & \\
\hline 17 & 2.1 & & 2.5 & & 2.3 & \\
\hline 18 & 2.3 & & 2.5 & & 2.2 & \\
\hline 19 & 2.4 & & 1.9 & & 2.4 & \\
\hline 20 & 2.4 & & 1.9 & & 2.4 & \\
\hline 21 & 2.0 & & 2.0 & & 2.0 & \\
\hline 22 & 2.1 & & 2.1 & & 2.3 & \\
\hline 23 & 2.3 & & 2.4 & & 2.4 & \\
\hline 24 & 2.5 & & 2.0 & & 2.5 & \\
\hline 25 & 2.1 & & 1.8 & & 2.5 & \\
\hline & $\begin{array}{l}\text { Total Dry } \\
\text { Mass }= \\
0.5280 \mathrm{~g}\end{array}$ & & $\begin{array}{l}\text { Total Dry } \\
\text { Mass }= \\
0.4240 \mathrm{~g}\end{array}$ & & $\begin{array}{l}\text { Total Dry } \\
\text { Mass }= \\
0.4915 \mathrm{~g}\end{array}$ & \\
\hline
\end{tabular}

Occasional multiple roots 
Results of Experiment Root \# 1

\begin{tabular}{|c|c|c|c|c|c|c|}
\hline \multicolumn{7}{|c|}{$\begin{array}{l}\text { Experiment RT \# } 1 \text { - Treatment \# } 3 \\
\text { Liquid } 1 / 4 \text { Strength MS + Vitamins }\end{array}$} \\
\hline & \multicolumn{2}{|c|}{ Flask \# 1} & \multicolumn{2}{|c|}{ Flask \# 2} & \multicolumn{2}{|c|}{ Flask \# 3} \\
\hline & \multicolumn{2}{|c|}{ Total $\#$ of pitchers $=220$} & \multicolumn{2}{|c|}{ Total \# of pitchers $=188$} & \multicolumn{2}{|c|}{$\begin{array}{l}\text { Total \# of pitchers = } \\
172\end{array}$} \\
\hline & $\begin{array}{l}\text { Length of } \\
\text { longest } 20 \\
\text { pitchers } \\
(\mathrm{cm})\end{array}$ & \multirow{26}{*}{$\begin{array}{l}\text { Roots } \\
\text { \# of } \\
\text { Rhizome } \\
\text { segments } \\
\text { examined = } \\
17\end{array}$} & $\begin{array}{l}\text { Length of } \\
\text { longest } 20 \\
\text { pitchers } \\
(\mathrm{cm})\end{array}$ & \multirow{26}{*}{\begin{tabular}{|l|} 
Roots \\
\\
\# of \\
Rhizome \\
segments \\
examined = \\
17
\end{tabular}} & $\begin{array}{l}\text { Length of } \\
\text { longest } 20 \\
\text { pitchers } \\
(\mathrm{cm}) \\
\end{array}$ & \multirow{26}{*}{$\begin{array}{l}\text { Roots } \\
\text { \# of } \\
\text { Rhizome } \\
\text { segments } \\
\text { examined } \\
=17\end{array}$} \\
\hline 1 & 2.6 & & 2.6 & & 2.8 & \\
\hline 2 & 2.3 & & 2.5 & & 3.0 & \\
\hline 3 & 2.4 & & 2.4 & & 2.1 & \\
\hline 4 & 2.8 & & 2.1 & & 2.5 & \\
\hline 5 & 2.1 & & 2.3 & & 2.6 & \\
\hline 6 & 2.9 & & 2.9 & & 2.4 & \\
\hline \begin{tabular}{|l|}
7 \\
\end{tabular} & 2.2 & & 3.0 & & 2.3 & \\
\hline 8 & 2.7 & & 2.8 & & 2.0 & \\
\hline 9 & 2.5 & & 3.0 & & 2.1 & \\
\hline 10 & 2.5 & & 2.1 & & 2.0 & \\
\hline 11 & 3.0 & & 2.4 & & 2.5 & \\
\hline 12 & 2.4 & & 2.6 & & 2.4 & \\
\hline 13 & 2.2 & & 2.1 & & 2.6 & \\
\hline 14 & 2.2 & & 2.0 & & 2.5 & \\
\hline 15 & 2.5 & & 2.7 & & 2.5 & \\
\hline 16 & 2.1 & & 2.8 & & 2.8 & \\
\hline 17 & 2.3 & & 2.4 & & 2.3 & \\
\hline 18 & 2.5 & & 2.3 & & 2.1 & \\
\hline 19 & 2.2 & & 2.5 & & 2.6 & \\
\hline 20 & 2.5 & & 2.6 & & 2.5 & \\
\hline 21 & 2.6 & & 2.4 & & 2.4 & \\
\hline 22 & 2.8 & & 2.1 & & 2.0 & \\
\hline 23 & 2.3 & & 2.2 & & 2.0 & \\
\hline 24 & 2.4 & & 2.7 & & 2.1 & \\
\hline 25 & 2.5 & & 2.3 & & 2.6 & \\
\hline & $\begin{array}{l}\text { Total Dry } \\
\text { Mass }= \\
0.3062 \mathrm{~g}\end{array}$ & & $\begin{array}{l}\text { Total Dry } \\
\text { Mass = } \\
0.2701 \mathrm{~g}\end{array}$ & & $\begin{array}{l}\text { Total Dry } \\
\text { Mass = } \\
0.2300 \mathrm{~g}\end{array}$ & \\
\hline
\end{tabular}

Multiple roots not present 
Results of Experiment Root \# 1

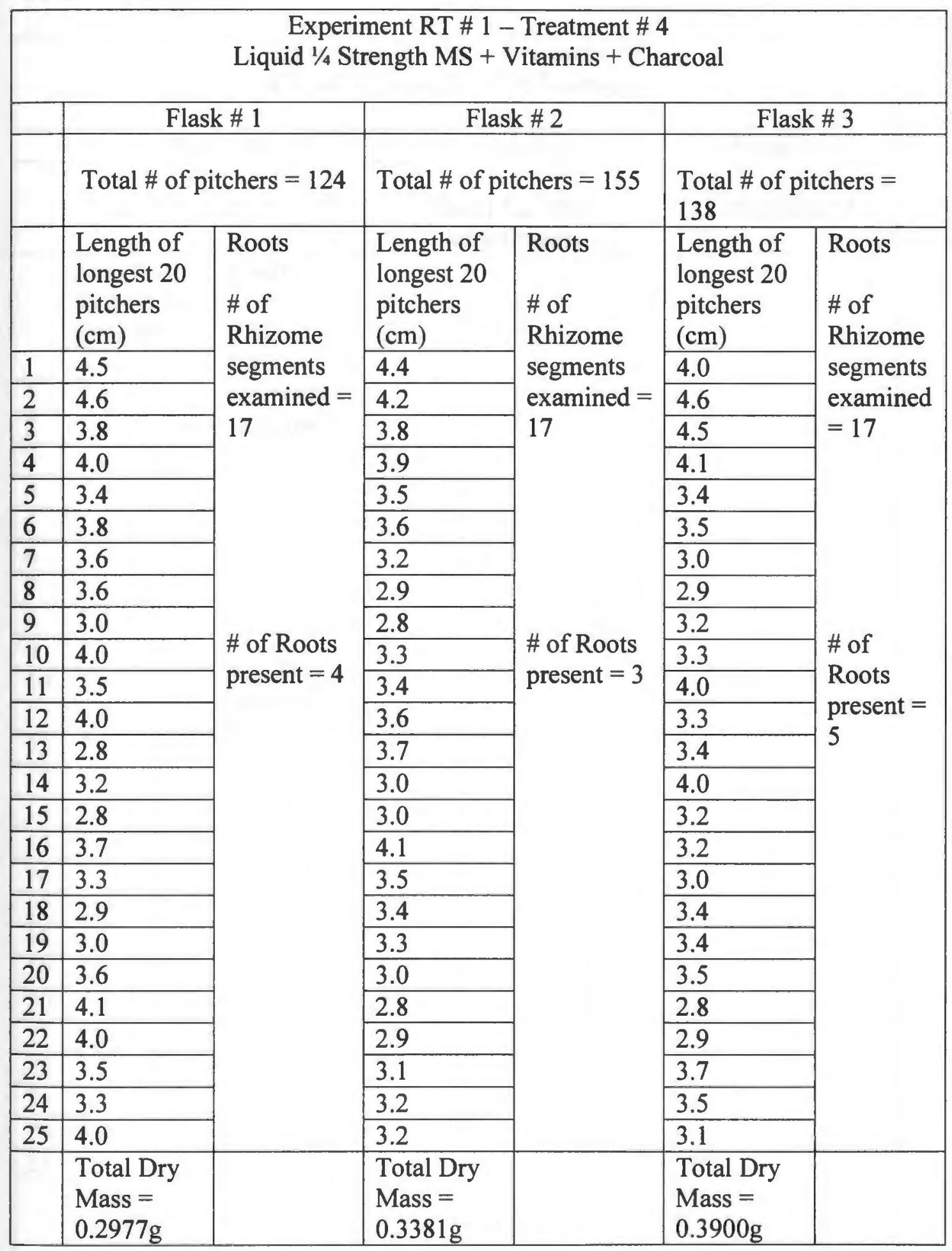

Multiple roots not present 
Results of Experiment Root \# 2

\begin{tabular}{|c|c|c|c|c|}
\hline \multicolumn{5}{|c|}{$\begin{array}{l}\text { Experiment RT \# } 2 \text { - Treatment \# } 1 \\
\text { Liquid } 1 / 2 \text { Strength MS + Vitamins }\end{array}$} \\
\hline & \multicolumn{2}{|c|}{ Flask \# 1} & Flask \# 2 & Flask \# 3 \\
\hline & \multicolumn{2}{|c|}{ Total \# of pitchers $=180$} & $\begin{array}{l}\text { Saved for future } \\
\text { exneriments }\end{array}$ & Contaminated \\
\hline & $\begin{array}{l}\text { Length of } \\
\text { longest } 20 \\
\text { pitchers } \\
(\mathrm{cm})\end{array}$ & \multirow{26}{*}{$\begin{array}{l}\text { Roots } \\
\text { \# of } \\
\text { Rhizome } \\
\text { segments } \\
\text { examined = } \\
17\end{array}$} & & \\
\hline 1 & 2.6 & & & \\
\hline 2 & 2.9 & & & \\
\hline 3 & 3.0 & & & \\
\hline 4 & 2.3 & & & \\
\hline 5 & 2.1 & & & \\
\hline 6 & 2.4 & & & \\
\hline 7 & 2.4 & & & \\
\hline 8 & 2.6 & & & \\
\hline 9 & 2.1 & & & \\
\hline 10 & 2.8 & & & \\
\hline 11 & 2.8 & & & \\
\hline 12 & 2.4 & & & \\
\hline 13 & 2.6 & & & \\
\hline 14 & 2.5 & & & \\
\hline 15 & 2.1 & & & \\
\hline 16 & 2.5 & & & \\
\hline 17 & 2.0 & & & \\
\hline 18 & 2.1 & & & \\
\hline 19 & 2.1 & & & \\
\hline 20 & 2.4 & & & \\
\hline 21 & 2.6 & & & \\
\hline 22 & 2.8 & & & \\
\hline 23 & 2.1 & & & \\
\hline 24 & 2.0 & & . & \\
\hline \multirow[t]{2}{*}{25} & 2.5 & & & \\
\hline & $\begin{array}{l}\text { Total Dry } \\
\text { Mass = } \\
0.488 \mathrm{~g}\end{array}$ & & & \\
\hline
\end{tabular}


Results of Experiment Root \# 2

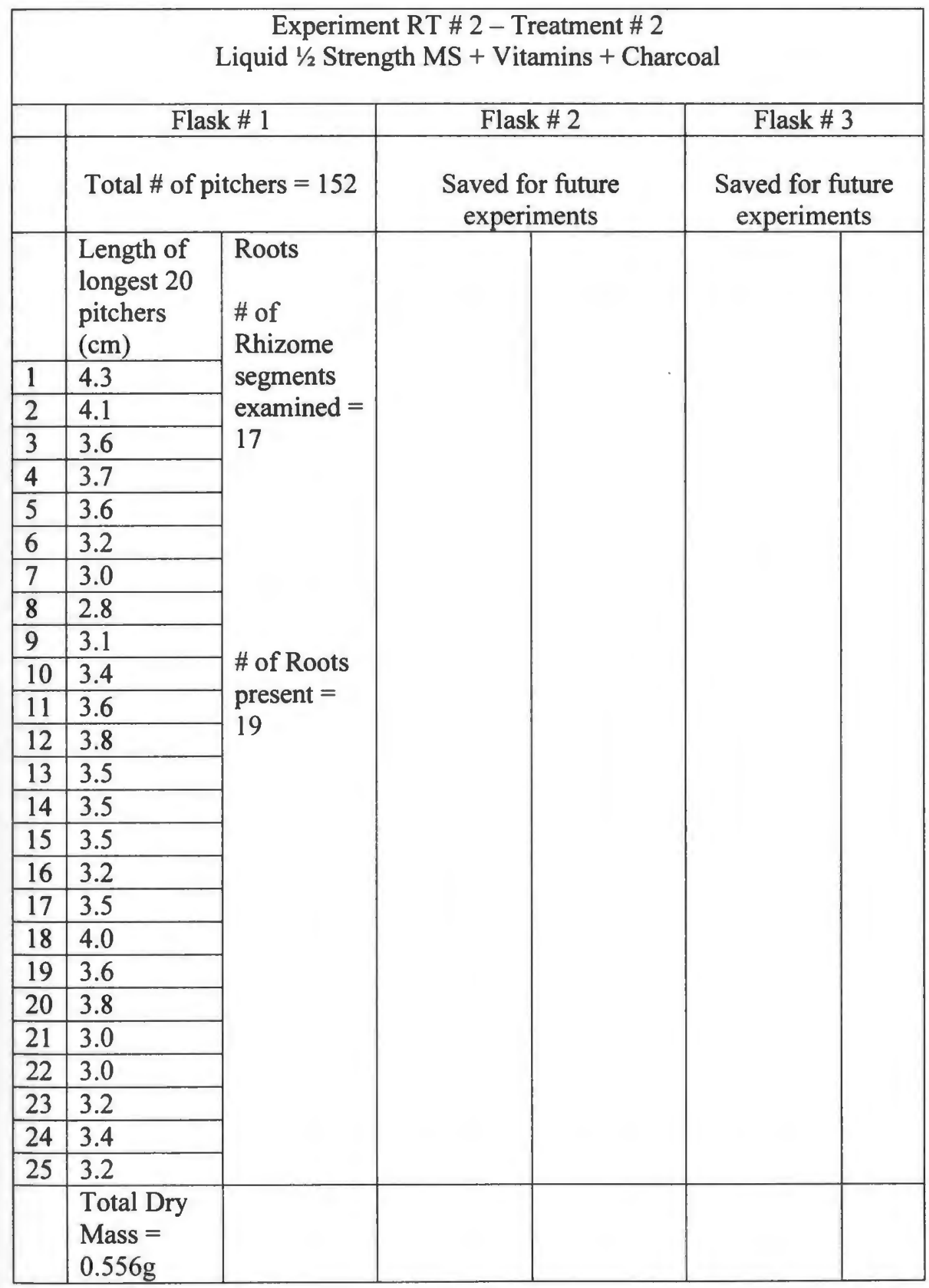


Results of Experiment Root \# 2

\begin{tabular}{|c|c|c|c|c|}
\hline \multicolumn{5}{|c|}{$\begin{array}{l}\text { Experiment RT \# 2-Treatment \# } 3 \\
\text { Liquid 1/4 Strength MS + Vitamins }\end{array}$} \\
\hline & \multicolumn{2}{|c|}{ Flask \# 1} & Flask \# 2 & Flask \# 3 \\
\hline & \multicolumn{2}{|c|}{ Total $\#$ of pitchers $=233$} & $\begin{array}{l}\text { Saved for future } \\
\text { experiments }\end{array}$ & Contaminated \\
\hline & $\begin{array}{l}\text { Length of } \\
\text { longest } 20 \\
\text { pitchers } \\
(\mathrm{cm})\end{array}$ & \multirow{26}{*}{\begin{tabular}{|l|} 
Roots \\
\\
\# of \\
Rhizome \\
segments \\
examined = \\
17
\end{tabular}} & & \\
\hline 1 & 2.8 & & & \\
\hline 2 & 2.8 & & & \\
\hline 3 & 2.5 & & & \\
\hline 4 & 2.5 & & & \\
\hline 5 & 2.3 & & & \\
\hline 6 & 2.4 & & & \\
\hline 7 & 2.2 & & & \\
\hline 8 & 2.8 & & & \\
\hline 9 & 2.7 & & & \\
\hline 10 & 2.5 & & & \\
\hline 11 & 2.2 & & & \\
\hline 12 & 2.2 & & & \\
\hline 13 & 2.1 & & & \\
\hline 14 & 3.0 & & & \\
\hline 15 & 2.3 & & & \\
\hline 16 & 2.6 & & & \\
\hline 17 & 2.1 & & & \\
\hline 18 & 2.7 & & & \\
\hline 19 & 2.4 & & & \\
\hline 20 & 2.6 & & & \\
\hline 21 & 2.2 & & & \\
\hline 22 & 2.1 & & & \\
\hline 23 & 2.4 & & & \\
\hline 24 & 2.4 & & & \\
\hline 25 & 2.5 & & & \\
\hline & $\begin{array}{l}\text { Total Dry } \\
\text { Mass = } \\
0.322 \mathrm{~g}\end{array}$ & & & \\
\hline
\end{tabular}


Results of Experiment Root \# 2

\begin{tabular}{|c|c|c|c|c|}
\hline & & $\begin{array}{r}\text { Experim } \\
\text { iquid } 1 / 4 \text { Stre }\end{array}$ & $\begin{array}{l}\text { \# 2-Treatmen } \\
\text { IS + Vitamins + }\end{array}$ & \\
\hline & & K\#1 & Flask \#2 & Flask \# 3 \\
\hline & Total \# of & tchers $=134$ & Contaminated & Contaminated \\
\hline & $\begin{array}{l}\text { Length of } \\
\text { longest } 20 \\
\text { pitchers } \\
(\mathrm{cm})\end{array}$ & $\begin{array}{l}\text { Roots } \\
\text { \# of } \\
\text { Rhizome }\end{array}$ & & \\
\hline 1 & 4.1 & segments & & \\
\hline 2 & 4.3 & examined $=$ & & \\
\hline 3 & 4.2 & & & \\
\hline 4 & 3.9 & & & \\
\hline 5 & 3.9 & & & \\
\hline 6 & 3.5 & & & \\
\hline 7 & 3.6 & & & \\
\hline 8 & 3.4 & & & \\
\hline 9 & 3.5 & & & \\
\hline 10 & 4.0 & \# of Roots & & \\
\hline 11 & 4.0 & & & \\
\hline 12 & 4.1 & & & \\
\hline 13 & 3.4 & & & \\
\hline 14 & 3.4 & & & \\
\hline 15 & 3.5 & & & \\
\hline 16 & 3.0 & & & \\
\hline 17 & 3.3 & & & \\
\hline 18 & 3.2 & & & \\
\hline 19 & 3.6 & & & \\
\hline 20 & & & & \\
\hline 21 & 3.0 & & & \\
\hline 22 & 3.2 & & & \\
\hline 23 & 3.2 & & & \\
\hline 24 & 3.4 & & & \\
\hline 25 & 3.5 & & & \\
\hline & $\begin{array}{l}\text { Total Dry } \\
\text { Mass }= \\
0.2977 \mathrm{~g}\end{array}$ & & & \\
\hline
\end{tabular}




\section{RESULTS ANCILLARY TO MANUSCRIPT III}

\section{Results of Metamorphosis Experiments: Series 1- Darlingtonia californica}

\section{Experiment \# Morph 1A}

Start Date 5/18/02

Seedlings approximately 4 weeks old that had germinated in $\mathrm{H}_{2} 0$ treatments from DC51 and DC52 were transferred to solid (8.5 g/l agar) POMM (200 ml in $500 \mathrm{ml}$ flasks), 12 seedlings were transferred to each flask. Flasks were placed in the growth chamber. As of 5/21/02 many seedlings were beginning to turn brown in both flasks. As of 7/28/02 three seedlings in flask \#1 formed protocorm-like structures and green, leafy callus. Two seedlings in flask \#2 formed similar masses of tissue.

Duration of experiment -70 days

Experiment \# Morph 1B (continuation of Morph 1A)

Start Date 7/30/02

The callus and protocorm-like structures formed in experiment $1 \mathrm{~A}$ were each cut into 3 smaller segments for a total of 15 segments. Five segments were transferred to each of $3,50 \mathrm{ml}$ Erlenmeyer flasks containing $10 \mathrm{ml}$ of liquid POMM. Flasks were placed in the growth chamber.

As of 8/15/02 (15 days of subculture) the segments in all 3 flasks show growth of shoots from both the segments of protocorm-like bodies and the green, leafy callus.

On 9/14/02 the flasks were photographed (44 days of subculture).

Experiment \# Morph 1C (continuation of Morph 1A and 1B)

Start Date 9/15/02

Following 45 days of subculture the clumps of shoots produced in two of the flasks were divided and subcultured again. The remaining flask was sacrificed for drawings and observations. Clumps of plants were evenly distributed among 3,250 ml Erlenmeyer flasks each containing $75 \mathrm{ml}$ of liquid POMM. The flasks were placed in the growth chamber. During the next 7 days there was an initial dieback of pitcher leaves. This was followed by a spurt of new growth. As of 10/15/ the plants in the flasks appeared healthy and were continuing to multiply.

\section{Experiment \# Morph 2}

Start Date $7 / 30 / 02$

Three seedlings, 3 months old, from experiment DC51 that had remained in $50 \mathrm{ml}$ Erlenmeyer flasks containing $10 \mathrm{ml}$ of $1 / 2$ strength liquid MS medium were divided into 2 
pieces each (by this time the seedlings had formed dense clusters of pitchers). Two clusters were placed in each of 3,500 ml Erlenmeyer flasks containing $50 \mathrm{ml}$ of liquid POMM. The flasks were placed in the growth chamber. On 8/15/02 one flask was used for experiment Morph 3B.By $9 / 17 / 02$ the plants in the remaining flasks had multiplied. One of the remaining 2 flasks was sacrificed to experiment Morph $3 \mathrm{C}$.

\section{Experiment \#Morph 3A}

Start date $-7 / 30 / 02$

This experiment was performored to test the regenerative ability of in vitro grown pitchers. Plantlets from experiment DC GAl were used. Pitchers were removed under sterile conditions and cut into 2-3 pieces. Pieces were placed in each of 3,50 ml Erlenmeyer flasks containing $10 \mathrm{ml}$ of MM medium. The flasks were placed in a growth chamber at $27^{\circ} \mathrm{C}$ with a $16 \mathrm{hr}$ photoperiod.

\begin{tabular}{|c|c|c|}
\hline \multicolumn{3}{|c|}{ Experiment Morph 3A } \\
\hline Flask \# 1 & Flask \#2 & Flask \# 3 \\
\hline 6 fragments & 7 fragments & 7 fragments \\
\hline $\begin{array}{c}\text { Aug. 15 -no new growth } \\
\text { plantlet }\end{array}$ & $\begin{array}{c}\text { Aug. 15 - 2 fragments } \\
\text { showing growth of } \\
\text { protocorm like structures }\end{array}$ \\
\hline $\begin{array}{c}\text { Sept. 14 -no new } \\
\text { growth }\end{array}$ & $\begin{array}{c}\text { Sept. 14 - photographed } \\
\text { Drawn on Sept. 15 }\end{array}$ & $\begin{array}{c}\text { Sept. 14 - photographed } \\
\text { Drawn on Sept. 15 }\end{array}$ \\
\hline \multicolumn{2}{|c|}{ 3 of a total of 20 fragments formed new growth structures } \\
This was the preliminary experiment that led to experiment Morph 2
\end{tabular}




\section{Results of Experiment \# Morph 3B}

Start date $-8 / 15 / 02$ - end date - 9/15/02

This experiment was performed to test the regenerative ability of whole pitchers, basal halves of pitchers, distal halves, pitcher fragments and whole seedlings. Explant material was placed in $8 \mathrm{ml}$ of liquid POMM in $125 \mathrm{~mm} \mathrm{X25} \mathrm{mm} \mathrm{test} \mathrm{tubes} \mathrm{and} \mathrm{placed} \mathrm{in}$ the growth chamber.

\begin{tabular}{|c|c|c|c|c|c|}
\hline $\begin{array}{c}\text { Tube } \\
\#\end{array}$ & $\begin{array}{l}\text { Treatment \#1 } \\
\text { Fragmented } \\
\text { pitchers } 2 \mathrm{~mm}- \\
5 \mathrm{~mm} \text { in length }\end{array}$ & $\begin{array}{l}\text { Treatment } \# 2 \\
\text { Whole } \\
\text { Pitchers } 0.75 \\
\mathrm{~cm} \text { to } 1.0 \mathrm{~cm} \\
\text { in length - } \\
1 \text { per tube }\end{array}$ & $\begin{array}{l}\text { Treatment \#3 } \\
\text { Basal portion } \\
\text { of pitchers } \\
\text { cut in half - } \\
1 \text { per tube }\end{array}$ & $\begin{array}{c}\text { Treatment \#4 } \\
\text { Distal } \\
\text { portion of } \\
\text { pitchers cut } \\
\text { in half - } \\
1 \text { per tube }\end{array}$ & $\begin{array}{l}\text { Treatment \#5 } \\
2 \text { whole } \\
\text { plantlets from } \\
\text { March } \\
\text { germination - } \\
\text { grown on } \\
\text { solid MS - } \\
1 \text { per tube }\end{array}$ \\
\hline \multicolumn{6}{|c|}{ As of $9 / 15 / 02$} \\
\hline 1 & $\begin{array}{c}4 \text { of } 8 \\
\text { fragments shoe } \\
\text { new growth - } \\
\text { others are } \\
\text { brown }\end{array}$ & $\begin{array}{l}\text { Brown - no } \\
\text { new growth }\end{array}$ & $\begin{array}{l}\text { Brown - no } \\
\text { new growth }\end{array}$ & $\begin{array}{l}\text { Brown - no } \\
\text { new growth }\end{array}$ & $\begin{array}{l}\text { One shows } \\
\text { greening and } \\
\text { new growth }\end{array}$ \\
\hline 2 & $\begin{array}{c}4 \text { of } 8 \\
\text { fragments shoe } \\
\text { new growth - } \\
\text { others are } \\
\text { brown }\end{array}$ & $\begin{array}{l}\text { Brown - no } \\
\text { new growth }\end{array}$ & $\begin{array}{l}\text { Brown - no } \\
\text { new growth }\end{array}$ & $\begin{array}{l}\text { Brown - no } \\
\text { new growth }\end{array}$ & $\begin{array}{c}\text { Turned } \\
\text { brown - no } \\
\text { new growth } \\
\text { present }\end{array}$ \\
\hline 3 & $\begin{array}{l}2 \text { fragments of } \\
10 \text { show new } \\
\text { growth - others } \\
\text { are brown }\end{array}$ & $\begin{array}{l}\text { Brown - no } \\
\text { new growth }\end{array}$ & $\begin{array}{l}\text { Brown - no } \\
\text { new growth }\end{array}$ & $\begin{array}{l}\text { Brown - no } \\
\text { new growth }\end{array}$ & \\
\hline 4 & $\begin{array}{c}8 \text { of } 8 \text { are } \\
\text { brown }\end{array}$ & $\begin{array}{l}\text { Brown - no } \\
\text { new growth }\end{array}$ & $\begin{array}{l}\text { Brown - no } \\
\text { new growth }\end{array}$ & $\begin{array}{l}\text { Brown - no } \\
\text { new growth }\end{array}$ & \\
\hline 5 & $\begin{array}{c}8 \text { of } 8 \text { are } \\
\text { brown }\end{array}$ & $\begin{array}{l}\text { Brown - no } \\
\text { new growth }\end{array}$ & $\begin{array}{l}\text { Brown - no } \\
\text { new growth }\end{array}$ & $\begin{array}{l}\text { Brown - no } \\
\text { new growth }\end{array}$ & \\
\hline 6 & $\begin{array}{c}1 \text { fragment of } 8 \\
\text { shows new } \\
\text { growth - } \\
\text { others are } \\
\text { brown }\end{array}$ & $\begin{array}{l}\text { Brown - no } \\
\text { new growth }\end{array}$ & $\begin{array}{l}\text { Brown - no } \\
\text { new growth }\end{array}$ & $\begin{array}{l}\text { Brown - no } \\
\text { new growth }\end{array}$ & \\
\hline & $\begin{array}{l}11 \text { of } 50 \\
\text { fragments } \\
\text { show new } \\
\text { growth }\end{array}$ & \multicolumn{3}{|c|}{0 of 18 show new growth } & $\begin{array}{l}1 \text { of } 2 \text { shows } \\
\text { new growth }\end{array}$ \\
\hline
\end{tabular}


Metamorphosis -Results of Exp. \# Morph 3C

Start Date $9 / 17 / 02$

Explant material for this experiment was obtained from a flask from Exp. Morph 2. Explants were placed in $125 \mathrm{~mm} \times 25 \mathrm{~mm}$ test tubes containing $10 \mathrm{ml}$ of liquid MM Medium and placed in the growth chamber at $27^{\circ} \mathrm{C}$ with a 16 hour photoperiod. Pitchers used were all $10 \mathrm{~mm}-18 \mathrm{~mm}$ in length. Data collected 10/17/02

\begin{tabular}{|c|c|c|c|c|c|c|c|c|c|}
\hline \multicolumn{10}{|c|}{ Experiment Morph 3C } \\
\hline \multirow[t]{2}{*}{$\begin{array}{c}\text { Tube } \\
\#\end{array}$} & \multirow{2}{*}{$\begin{array}{c}\text { Treatment } \\
\# 1 \\
\text { Whole } \\
\text { Pitchers }\end{array}$} & \multirow[t]{2}{*}{$\begin{array}{l}\text { Treatment } \\
\quad \# 2 \\
\text { Basal } 1 / 2\end{array}$} & \multirow[t]{2}{*}{$\begin{array}{c}\text { Treatment } \\
\# 3 \\
\text { Distal } 1 / 2\end{array}$} & \multirow{2}{*}{$\begin{array}{c}\text { Treatment } \\
\# 4 \\
\text { Basal } \\
\text { Fragments }\end{array}$} & \multirow{2}{*}{$\begin{array}{c}\text { Treatment } \\
\text { \#5 } \\
\text { Distal } \\
\text { Fragments }\end{array}$} & \multicolumn{4}{|c|}{$\begin{array}{c}\text { Treatment } \# 6 \\
\text { Serial } \\
\text { Fragments }\end{array}$} \\
\hline & & & & & & $\begin{array}{l}6 \\
\mathrm{a}\end{array}$ & $\begin{array}{l}6 \\
b\end{array}$ & $\begin{array}{l}6 \\
\mathrm{c}\end{array}$ & $\begin{array}{l}6 \\
d\end{array}$ \\
\hline 1 & - & - & - & - & - & - & - & - & - \\
\hline 2 & - & - & - & - & - & - & - & - & - \\
\hline 3 & - & - & - & - & - & - & - & - & - \\
\hline$\overline{4}$ & - & $\begin{array}{c}\text { Remained } \\
\text { green }\end{array}$ & $\begin{array}{c}\text { Remained } \\
\text { green }\end{array}$ & - & - & - & - & - & - \\
\hline 5 & - & - & - & - & - & - & - & - & - \\
\hline 6 & - & - & - & $\begin{array}{c}\text { remained } \\
\text { green }\end{array}$ & $\begin{array}{l}\text { Remained } \\
\text { green }\end{array}$ & - & - & - & - \\
\hline 7 & - & $\begin{array}{l}\text { New } \\
\text { pitcher } \\
\text { formed }\end{array}$ & - & - & - & - & - & - & - \\
\hline 8 & - & - & - & - & - & - & - & - & - \\
\hline 9 & - & - & - & - & - & - & - & - & - \\
\hline 10 & - & - & - & - & - & - & - & - & - \\
\hline 11 & - & - & - & - & - & - & - & - & - \\
\hline 12 & - & - & - & - & - & - & - & - & - \\
\hline 13 & - & - & - & - & - & - & - & - & - \\
\hline 14 & - & - & - & - & - & - & - & - & - \\
\hline 15 & $\begin{array}{l}\text { Growth } \\
\text { from tip }\end{array}$ & - & - & - & - & - & - & - & - \\
\hline & $\begin{array}{c}1 \text { of } 15 \\
\text { new } \\
\text { growth }\end{array}$ & $\begin{array}{c}1 \text { of } 15 \\
\text { new } \\
\text { growth }\end{array}$ & 0 & 0 & 0 & 0 & 0 & 0 & 0 \\
\hline & & & & & & & & & \\
\hline & & & & & & & & & \\
\hline
\end{tabular}

- $\quad$ = Browned and died (no new growth) 


\section{Experiment \# Morph 4}

Start Date $9 / 18 / 02$

End Date 10/15/02

(36 day duration)

2-3 week old seedlings from experiment DCGEM2002C, treatment \#2 (24 hr soak in $\mathrm{H}_{2} \mathrm{O}$ ) and treatment $\# 3$ ( $24 \mathrm{~h} \mathrm{hr}$ in $\mathrm{GA}_{3}$ ) were transferred from water agar to corning $25 \mathrm{ml}$ polystyrene tissue culture flasks containing $9 \mathrm{ml}$ of liquid POMM. Four seedlings per flask, four replicates from each treatment.

Results as of $10 / 15 / 02$

\begin{tabular}{|l|l|l|}
\hline Flask \# & $\begin{array}{l}\text { Treatment \# 1 (seedlings from } \\
\text { DCGEM2002C treatment \#2) }\end{array}$ & $\begin{array}{l}\text { Treatment \#2 (seedlings from } \\
\text { DCGEM2002C treatment \#3) }\end{array}$ \\
\hline 1 & All 4 brown & $\begin{array}{l}3 \text { show very green protocorm-like } \\
\text { structures, 1 brown }\end{array}$ \\
\hline 2 & $\begin{array}{l}2 \text { show green growth } \\
2 \text { brown }\end{array}$ & $\begin{array}{l}1 \text { green, long pitcher } \\
3 \text { brown }\end{array}$ \\
\hline 3 & $\begin{array}{l}2 \text { show green but browning } \\
2 \text { brown }\end{array}$ & $\begin{array}{l}\text { 2 very green } \\
1 \text { beginning to brown } \\
1 \text { brown }\end{array}$ \\
\hline 4 & $\begin{array}{l}1 \text { shows new green growth of } \\
\text { protocorm-like structure } \\
3 \text { brown }\end{array}$ & $\begin{array}{l}2 \text { breen } \\
2\end{array}$ \\
\hline & 5 of 16 show new growth & 8 of 16 show new growth \\
\hline
\end{tabular}

\section{Experiment \# Morph 5}

Start Date $9 / 15 / 02$

This experiment was conducted to gather preliminary observations on growth of D. californica in full strength liquid MS. 3-4 week old seedlings from exp.

DCGEM2002C, treatment \#2 (24 soak in $\mathrm{H}_{2} \mathrm{O}$ ) were placed, 6 per flask, in $75 \mathrm{ml}$ of liquid full strength MS medium in $250 \mathrm{ml}$ erlenmyer flasks and placed in the growth chamber. As of 10/15/02 1 has browned and the others remain green but growth is very slow. Photographs were taken on 10/16/02. 


\section{Experiment Morph \#6A}

Start Date $-7 / 30 / 02$

Two seedlings of S. leucophylla that had germinated on 3/2/02 on MYP (as part of surface sterilization experiments) were transferred on 3/15/02 to solid $1 / 2$ strength MS medium in $125 \mathrm{~mm}$ X25 mm test tubes. On 4/15/02 the two seedlings showed little growth and no multiplication, They were transferred to solid POMM. On 7/30/02 (after 3 $1 / 2$ months of growth), during which they produced few new shoots and increased rhizome length only slightly, they were transferred to a $500 \mathrm{ml}$ Erlenmeyer flask containg $50 \mathrm{ml}$ of liquid POMM. BY 9/15/02 they had formed clusters of pitchers with large rhizomes that could be divided, these were divided into several pieces and placed in three, $250 \mathrm{ml}$ erlenmyer flasks containing $75 \mathrm{ml}$ of liquid POMM and returned to the growth chamber. On 10/20/02 they were photographed, divided and placed in three, 500 $\mathrm{ml}$ Erlenmeyer flasks containing $100 \mathrm{ml}$ of POMM.

\section{Experiment Morph \# 6B}

Start Date - 9/15/02

When 6 month old pitchers from Morph \#6A were transferred to new medium, four pitchers were fragmented and seven fragments were placed in each of four plastic tissue culture flasks containing $9 \mathrm{ml}$ of liquid POMM. All were placed in the growth chamber under the same conditions that had allowed regeneration in D. californica fragments.

As of 10/15/02, all had turned brown. Two turned slightly red after the first week and appeared to swell but after 30 days they had turned brown and apparently died.

\section{Experiment Morph \# 7}

Start Date $-4 / 29 / 02$

Two young pitchers were harvested from mature greenhouse grown plants (1 from each plant). One pitcher was approx. 6-7 weeks old and the other approx. 2-3 weeks old The pitchers were cut from the plants at the base of zone 5 using a sterile dissecting scissors. Care was taken not to include any portion of the rhizome. Following surface sterilization ( $20 \%$ Clorox, $10 \mathrm{~min}, 3,3$ min rinses) sections were cut from each zone with a sterile scalpel. The sections were placed in $250 \mathrm{ml}$ Erlenmeyer flasks containing $75 \mathrm{ml}$ of POMM. Three flasks were used for each pitcher with the sections being placed in the following order:

\begin{tabular}{|c|c|c|c|}
\hline & Flask 1 & Flask2 & Flask 3 \\
\hline $\begin{array}{l}2-3 \text { week old } \\
\text { pitcher }\end{array}$ & 1 zone 5,2 zone 4 & 2 zone 3 & 1 zone 2,2 zone 1 \\
\hline $\begin{array}{l}5-7 \text { week old } \\
\text { pitcher }\end{array}$ & 1 zone 5,2 zone 4 & 2 zone 3 & 1 zone 2,2 zonel \\
\hline \multicolumn{4}{|c|}{$\begin{array}{l}5 / 6 / 02 \text { - Flask } 1 \text { and } 2 \text { contaminated in } 5-7 \text { week old pitcher - no contam. In 2-3 wk } \\
\text { old } \\
5 / 12 / 02 \text { All flasks, all segments, contaminated }\end{array}$} \\
\hline
\end{tabular}




\section{Experiment Morph \# 8}

Start Date - 8/1/02

Three unopened pitchers were harvested from three individuals in a population in the Great Swamp. Pitcher sizes were $2.8 \mathrm{~cm}, 4.0 \mathrm{~cm}$ and $6.2 \mathrm{~cm}$. Pitchers were washed for 15 minutes in slowly running tapwater +3 drops of Tween-20, surface sterilized in $3 \% \mathrm{H}_{2} \mathrm{O}_{2}$ for $5 \mathrm{~min}$, then cut into zonal segments. The largest pitcher opened during washing. Zonal segments were cut and placed in liquid POMM $(10 \mathrm{ml})$ in $50 \mathrm{ml}$ Erlenmeyer flasks with five flasks used per pitcher. Segments were placed in flasks as follows:

\begin{tabular}{|l|l|l|l|}
\hline zone & $\begin{array}{l}2.8 \mathrm{~cm} \text { pitcher } \\
\text { \# of segments }\end{array}$ & $\begin{array}{l}4.0 \mathrm{~cm} \text { pitcher } \\
\text { \# of segments }\end{array}$ & $\begin{array}{l}6.2 \mathrm{~cm} \text { pitcher } \\
\text { \# of segments }\end{array}$ \\
\hline 1 & 1 & 1 & 2 \\
\hline 2 & 1 & 1 & 1 \\
\hline 3 & 2 & 1 & 1 \\
\hline 4 & 2 & 2 & 5 \\
\hline 5 & 1 & 2 & 3 \\
\hline As of $8 / 12$ all flasks had contaminated \\
\hline
\end{tabular}

\section{Experiment Morph \# 9}

Start Date $-9 / 5 / 02$

One, unopened pitcher $(1.8 \mathrm{~cm}$ in height) was harvested from a greenhouse grown plant, cleaned in a mild detergent for several minutes under running tapwater and surface sterilized in $3 \% \mathrm{H}_{2} \mathrm{O}_{2}$ for 10 minutes. The pitcher was cut into nine fragments, $2 \mathrm{~mm}$ in length, in sequence from zone 5 (\#1 fragment) to zone 1(\#9 fragment ) and one fragment per tube was placed in each of $9,125 \mathrm{~mm} \mathrm{X} 25 \mathrm{~mm}$ test tubes containing $10 \mathrm{ml}$ of liquid POMM. The tubes were placed in the growth chamber. After, $24 \mathrm{hr}$. contamination was observed in tube \#1. After $48 \mathrm{hrs}$ contamination was observed in tube 2. Contamination was observed in tubes 3 and 4 after $72 \mathrm{hrs}$. At the end of seven days all had contaminated. 


\section{APPENDIX B}

\section{A REVIEW OF SELECTED PAPERS FROM THE LITERATURE ON THE TISSUE CULTURE AND MICROPROPAGATION OF CARNIVOROUS PLANTS}

\section{ABSTRACT}

Selected papers from the literature regarding micropropagation of carnivorous plants have been reviewed. Current techniques in the literature for the surface disinfestation of seeds and subsequent micropropagation from in vitro generated plant material are discussed and tables presented. A baseline series of protocols has been extracted from the literature for the in vitro study of carnivorous plants in the laboratory.

\section{INTRODUCTION}

Carnivorous plant species have long been objects of study because they possess unique physiological and anatomical adaptations peculiar to the carnivorous habit (see Lloyd, 1942, for early references). This collection of artificially grouped plants comprises over 600 species (Adamec, 1997) and has grown considerably since 1989 when Givnish reported 538 species. The taxonomic occurrence of these plants is spread over 10 families and 19 genera (table1). Givnish reported eight families and 18 genera in 1989. This group is important for several reasons. Several members of the genus Drosera and the related single species genus Dionaea are used in the preparation of medicinal compounds and for the extraction of other secondary metabolites (Bobak et al., 1995; Bobak et al., 1993; Budzianowski, 2001; 1997; 1996; 
1995; Crouch et al., 1990; and Zenk and Steglich, 1969. Collection pressure and/or habitat destruction has reduced or depleted many natural populations of carnivorous plants in the wild (Anthony, 1992). Many species of carnivorous plants are considered threatened or endangered with many currently listed in the list of protected species at either the national or international level by the Convention on International Trade in Endangered Species (Boulay, 1995).

Carnivorous plants are increasingly being used as model systems for the study of fundamental problems in plant development (Bobak et al., 1995; Bobak et al., 1993; Leichtscheidle, et al., 1989; Samaj, et al., 1995). The widespread use of plant tissue culture as a technique for micropropagation has resulted in an increase in recent research on carnivorous plants. Many species such as Nepenthes, Sarracenia, Darlingtonia, Cephalotus and the many Drosera species are avidly sought by private collectors and possess particular horticultural value. Additionally, Baskin and Baskin (1998) group the carnivorous plant species collectively under the heading of plants with specialized life cycles or habitats.

With the work on the Arabidopsis genome nearing completion it is timely to begin investigating and developing other plant model systems. The carnivorous plants present an opportunity to study a variety of unique nutritional, ecological, morphological, and developmental adaptations which have arisen independently in several plant families and genera that share a common ecology and habit.

The literature contains very little specific information on seeds and embryos of carnivorous plants. It has been summarized by Baskin and Baskin (1998). These authors tabulated dormancy requirements and germination requirements for seeds of 
13 carnivorous plant genera. However, except for the single species genera of Aldrovanda, Cephalotus, Darlingtonia, Dionaea and Drosophyllum their table is not species specific and germination of carnivorous plants in the laboratory under aseptic conditions is not addressed.

The widespread use of plant tissue culture as a technique for micropropagation has resulted in an increase in recent research on carnivorous plants. Much of the literature reports the use of surface sterilized seeds as a source of explant material for in vitro culture. Various methods are reported for breaking dormancy and achieving germination. While it is not within the scope of these papers to address problems regarding types of dormancy, clarification of the problem will facilitate future research in developing micropropagation protocols for additional species. One problem that has to be addressed is that the use of disinfectants in the laboratory generally negates data from application to the ecology and timing of germination in nature since seeds in nature are exposed to many types of soil microorganisms and environmental factors (Baskin and Baskin, 1998). However, knowledge of the phenology of the seed phase of the plant life cycle can contribute significantly to successful germination in the laboratory.

Baskin and Baskin (1998) suggest that most species of carnivorous plants have dormant seeds with some being non-dormant. According to these authors, physiological dormancy is the most common type of dormancy found within the carnivorous plant group with a few species having morphological or morphophysiological dormancy. 
The following selective, chronology details some of the history of laboratory work with carnivorous plants. Data and observations pertaining to seeds and/or surface sterilization of seeds and other explant tissues has been extracted and presented in a series of tables. In summary, any attempt to establish a micropropagation system or micropropagation protocols for selected carnivorous plant species must begin with a survey of the literature.

\section{A LOOK AT THE LITERATURE}

Burgher (1961) - Burgher reported a method for the sterilization of seeds of Drosera intermedia, a germination protocol, and a medium that allowed only limited growth of plantlets. Most important were his observations that the highest germination occurred when the seeds were exposed to a cycle of $12 \mathrm{~h}$ of light at $38^{\circ} \mathrm{C}$ followed by $12 \mathrm{~h}$ of light at $15^{\circ} \mathrm{C}$. No dark period was necessary. However, when seeds were exposed to $12 \mathrm{~h}$ of darkness at $15^{\circ} \mathrm{C}$, germination was approximately $13 \%$ less than that obtained in constant light. Seeds were illuminated with two, 40 watt, cool-white fluorescent bulbs. Germination occurred after five weeks of treatment. Burgher reported that the medium used for his experiments was not satisfactory for continued growth and maintenance of the seedlings. He also reported that exposure of the seeds to IAA (indole-3-acetic acid), gibberellic acid, dilute sulfuric acid, high temperature $\left(37^{\circ} \mathrm{C}\right)$ or freezing followed by either high or room temperature did not enhance germination. He did not report concentrations or exposure times. 
Pringsheim and Pringsheim (1962) - These researchers obtained axenic cultures of Uticularia exoleta in liquid culture using a modification of a medium developed for the growth of the green alga Micrasterias. Paramount among their experimental results are the observations that peptone and meat extract added to the basal medium not only promoted superior growth of the plants but also caused the plants to flower. They reported the concentrations employed as $0.05 \%$ each of Difcotryptone and Difco-beef extract. They also reported that peptone, used alone, improved growth slightly but beef extract was necessary for flower production. Additionally, they reported that growth of cultured plants was much improved when the medium was prepared by dissolving iron sulfate crystals after the chelating agent (EDTA) was added to the medium and before addition of other trace elements.

Withner (1964) - Withner was the first to report a protocol for the culture of immature seeds (described by Withner as fertilized ovules) from surface sterilized seed capsules of carnivorous plants. He also reported a medium that allowed sustained growth and proliferation of cultured plantlets of Darlingtonia californica, Dionaea muscipula, Sarracenia flava, and $S$. purpurea. He prepared a germination medium composed of chopped fresh sphagnum (amount not reported), sucrose (not quantified), and potassium nitrate (not quantified). This medium gave excellent germination (not quantified), growth and proliferation. However, he states growth was enhanced by $40 \%$ on Burgeff $\mathrm{N}_{3}$ f medium (a medium used for the germination of orchids), plus $0.5 \mathrm{~g} / \mathrm{l}$ casamino acids (casein hydrolysate). Additionally, he reported that substituting peat moss for sphagnum resulted in similar germination and growth. 
However, sphagnum allowed the best percentage of germination and growth. In his experiments, plants grown in the dark on Burgeff $\mathrm{N}_{3}$ f medium were still able to grow enough to fill the flasks. According to Withner, Darlingtonia proliferated very rapidly on Burgeff $\mathrm{N}_{3} \mathrm{f}$ medium. Lighting conditions were $16 \mathrm{~h}$ of fluorescent light followed by $8 \mathrm{~h}$ of darkness.

Swamy and Ram (1969) - Surface sterilized seeds of Utricularia inflexa were plated on modified White's medium (liquid and semisolid; $0.8 \%$ agar). Germinated seedlings were subsequently used as sources of explant material for further in vitro studies. Explant material consisted of internodes $(0.5-1.5 \mathrm{~cm}$ in length), nodes with half each of the two adjacent internodes $(0.8 \mathrm{~cm}$ in length), portions of the stolons comprising 2-4 nodes (2.0-2.5 cm long), shoot tips (1.0-1.5 cm long) and leaf lobes ( $0.5 \mathrm{~cm}$ long). All explants were successful except internodal explants which failed to reorganize any meristematic tissue. Also reported was good vegetative growth when $500 \mathrm{mg} / \mathrm{l}$ of beef extract, casein hydrolysate, peptone, tryptone, or yeast extract were added to the basal medium. They observed the following effects of growth substances on seed germinating and seedling morphology. 1) $\mathrm{GA}_{3}$ at $3.4 \mathrm{ppm}$ stimulated germination; 2) $\mathrm{GA}_{3}$ at $6.8 \mathrm{ppm}$ depressed germination;3) IAA inhibited germinations at both concentrations tested $(5 \mathrm{ppm}$ and $10 \mathrm{ppm}) ; 4)$ kinetin at $0.5 \mathrm{ppm}$ and $1.0 \mathrm{ppm}$ stimulated germination; 5) Neither kinetin nor $\mathrm{GA}_{3}$ caused any significant change in seedling morphology; 6) IAA at $10 \mathrm{ppm}$ caused etiolation of seedlings, epinasty of cotyledonoids, slender stolons, and more finely dissected leaf lobes than those of the control group. 
Chandler and Anderson (1976) - Hydrolytic enzymes associated with the leaves and tentacles of Drosera species and their role in heterotrophic nutrition were studied. During the course of these studies Drosera binata was introduced into axenic culture. Seeds less than four weeks old were harvested and surface sterilized in a solution of benzalconium chloride $(0.1 \% \mathrm{w} / \mathrm{v})$ and calcium proprionate $(18 \mathrm{mM})$. Sterilization time was $15 \mathrm{~min}$. The seeds were next washed with sterile distilled water and transferred to $500 \mathrm{ml}$ flasks containing $180 \mathrm{ml}$ of culture medium as described by Lidell (1953). However, the agar percentage was reduced to $0.65 \%(w / v)$. Neither contamination rates nor germination percentages are given. Germinated seedlings were explanted (one per flask) and raised under a bank of fluorescent and grow-lux tubes. The tubes supplied $8.5 \mathrm{Wm}^{-2}$ at the agar surface. Insects were autoclaved and applied aseptically to the plants as part of the nutritional studies.

Adams et al., (1979a) - These workers reported the clonal multiplication of Cephalotus follicularis on $1 / 2$ strength Linsmaier-Skoog medium with $30 \mathrm{~g} / 1$ sucrose and $8 \mathrm{~g} / \mathrm{l}$ agar ( $\mathrm{pH}$ adjusted to 5.7-5.8 prior to agar addition). Thiamine and inositol were also reduced to $1 / 2$ strength. Shoot tips were excised, surface sterilized and initially cultured on the above medium with $0.1 \mathrm{mg} / \mathrm{l}$ indolebutyric acid (IBA) and 1.0 $\mathrm{mg} / \mathrm{l}$ benzyladenine (BA). The cultures were kept in the dark for 6 weeks to prevent the accumulation of phenolic oxidation compounds that form in the presence of light and often kill the explanted tissue. The tissue was then transferred for 8 weeks to conditions of constant light $(2.2-3.2 \mathrm{klx})$ and constant temperature $\left(21-25^{\circ} \mathrm{C}\right)$. 
Following the light and temperature treatment the tissue was transferred to a medium containing $0.1 \mathrm{mg} / 1$ napthaleneacetic acid (NAA) and $0.1 \mathrm{mg} / 1 \mathrm{BA}$. They reported rapid proliferation of plantlets on this medium with a 5-10 fold increase in plantlet numbers after each subculture. They noted that full strength medium produced less vigorous growth. Additionally, they reported that the micropropagation of Cephalotus was also achieved in liquid culture using the same medium without the addition of agar. Rotated liquid cultures broke apart to form many small clumps while shaken cultures proliferated as a solid mass. Growth in liquid cultures was accompanied by an initial die-back of tissue at pH 5.7. However, no die-back occurred in medium adjusted to $\mathrm{pH}$ 5.0. Growth at $\mathrm{pH} 5.0$ was also more rapid.

Adams et al., (1979b) - The in vitro propagation of the butterwort Pinguicula moranensis from excised, surface sterilized leaves of mature plants on 1/5 strength Lindsmaier-Skoog medium was reported. The medium also contained $30 \mathrm{~g} / \mathrm{l}$ sucrose and the $\mathrm{pH}$ was adjusted to 6.5 before adding $6 \mathrm{~g} / \mathrm{l}$ agar. Leaves placed on full strength medium died. Leaves cultured on this medium without hormones produced an average of three leaves per leaf. Leaves from these aseptic seedlings grown on the above medium were transferred to the same medium containing hormones $(0.02 \mathrm{mg} / \mathrm{l}$ 6-benzylamino purine (BA) and $0.01 \mathrm{mg} / 1$ napthaleneacetic acid (NAA)). This hormonal ratio produced a combined maximum number of plantlets and growth rate. Plantlet yield was increased by subculturing to higher hormonal levels (BA $2.0 \mathrm{mg} / \mathrm{l}$ : NAA $1.0 \mathrm{mg} / \mathrm{l}$ ) for three to four weeks then plantlets were subcultured back to the lower hormonal concentrations to maximize growth. These workers estimated that a 
single leaf producing seven to eight, three leaved plantlets could be expected to produce 500 plantlets in six months of culture.

Beebe (1980) - Beebe described aseptic germination, callus formation, and adventitious bud development in Dionaea muscipula. He germinated seeds on full strength MS medium with the following supplements: thiamine, $0.1 \mathrm{mg} / 1$; nicotinic acid, $0.5 \mathrm{mg} / \mathrm{l}$; pyridoxine, $0.5 \mathrm{mg} / 1$; glycine, $2 \mathrm{mg} / 1$; myo-inositol, $100 \mathrm{mg} / 1$; casein hydrolysate, $1.0 \mathrm{~g} / 1$; sucrose, $20 \mathrm{~g} / 1$; coconut milk, $1.5 \%$ (v/v); and $1.0 \%$ agar. The $\mathrm{pH}$ of the medium was adjusted to 5.6 before autoclaving. Beebe reported germination and early seedling development to be as described by Smith (1931) for seeds germinated in soil under greenhouse conditions. He stated that over a four -year period, several different seed lots were used with germination ranging from $78 \%$ in a sample of 95 seeds to $40 \%$ in a sample of 150 seeds. Seeds germinated throughout a 10-55 day period with the majority (over $70 \%$ ) germinating between 10 and 35 days.

Various concentrations of growth substances were applied to this medium for developmental studies. The growth substances used were 1-napthaleneacetic acid (NAA) and N6-benzyladenine (BA). High ratios of NAA to BA promoted the production of roots from both aseptically germinated seedlings and from callus tissue. Equal ratios of NAA to BA promoted the proliferation of callus and callus buds from both cultured seedlings and callus other callus buds. He also observed that seedlings on medium containing $10^{-7} \mathrm{M}$ of NAA and $10-{ }^{5} \mathrm{M}$ BA formed large, fleshy adventitious buds at the tips of broad petioles. The petiole margins on these plantlets were ruffled. These buds, which he termed "callus-buds", formed in place of traps at 
the leaf tips. Beebe also reported that rapid callus formation and bud growth occurred on media containing $10^{-6} \mathrm{M}$ of NAA $+10^{-7} \mathrm{M}$ of BA, $10^{-6} \mathrm{M}$ of NAA $+10^{-6} \mathrm{M}$ of BA and $10^{-7} \mathrm{M}$ of NAA $+10^{-6} \mathrm{M}$ of BA. Lastly, he reported that compact, slow growing, green callus was obtained on a medium containing $10^{-8} \mathrm{MNAA}+10^{-5} \mathrm{M}$ of BA.

Parliman et al., (1982a) - Parliman and co-workers used single rhizome explants from aseptically germinated seedlings as a source of explant material to establish proliferating cultures of Dionaea muscipula (venus flytrap). Seeds were germinated on MS medium. However the authors are not specific regarding the strength of the medium. Staba vitamins (Staba, 1969), $100 \mathrm{mg} / \mathrm{l}$ myo-inositol, 100 $\mathrm{mg} / \mathrm{l}$ casein hydrolysate, and $30 \mathrm{~g} / \mathrm{l}$ sucrose were also added to the germination medium. The $\mathrm{pH}$ was adjusted to 5.9 before adding agar $(6.7 \mathrm{~g} / \mathrm{l})$. Following germination, plantlets were subcultured to $1 / 2$ strength basal MS medium (including the additional components listed above) plus $1.9 \mathrm{mg} / \mathrm{l}$ napthaleneacetic acid (NAA) and $0.2 \mathrm{mg} / \mathrm{l} 6$-benzlamino purine (BA). The $\mathrm{pH}$ was adjusted to 4.9 prior to the addition of $6.7 \mathrm{~g} / \mathrm{l}$ agar. Explants grown on this medium showed a 5-14 fold increase in the number of healthy, vigorous, rooted plantlets in 60 days. Plantlets were next transferred to an acclimatization or pre-transplant medium. The authors state that this medium allowed the rapid increase in size of the subcultured plantlets but did not allow an increase in the number of plantlets. The composition of the medium was $1 / 2$ strength MS medium with organic components as above except the NAA and BA were removed and $\mathrm{GA}_{3}$ at $0.3 \mathrm{mg} / \mathrm{l}$ or $1.0 \mathrm{mg} / \mathrm{l}$ was added. The authors reported that after 40 days growth on this medium plantlets were ready to be transferred ex vitro. 
Parliman et al., (1982b) - Parliman and co-workers reported adventitious bud differentiation and development from tissue cultured leaf cuttings of Dionaea muscipula. The source of the leaf cuttings for these experiments was aseptically germinated seedlings as described in their previous work (Parliman et al., (1982a). They expected adventitious buds to arise independently from the leaf tissue. However, secondary buds developed from the rhizomes of primary adventitious buds with each secondary bud initiating another secondary bud in a chain-like fashion. They termed these secondary buds lateral buds (LB) as opposed to the primary adventitious bud (AB). They presumed that these buds developed from meristematic tissue within the $A B$ rhizomes. They also stated that the origin of the $A B$ buds is unknown (whether from single or multiple cell origin). The medium employed for these experiments was $1 / 2$ strength MS with organic supplements as described earlier (Parliman et al., 1982a). Hormonal concentrations that produced the greatest number of $\mathrm{AB}$ and $\mathrm{LB}$ buds were NAA at $1.9 \mathrm{mg} / \mathrm{l}+6(-\mathrm{y}$-y-dimethylallylamino)-purine (2iP) at $0.2 \mathrm{mg} / \mathrm{l}$. Additionally, they reported that leaves dipped for $24 \mathrm{~h}$ in $2 \mathrm{iP}$ at $2.1 \mathrm{mg} / \mathrm{l}$ produced the greatest number of adventitious and lateral bud derived plantlets when subsequently cultured on the above medium.

Bonnet et al., (1984) - Whole plants and seeds of Drosera rotundifolia were field collected near Spa (Belgium Ardennes). Both whole plants and seeds were surface sterilized for $15 \mathrm{~min}$ in $2 \%$ bleach followed by two washes in sterile distilled water. Seeds were germinated on $1 / 4$ strength MS medium (Murashige and Skoog, 
1962). The MS medium was supplemented with various concentrations of BAP (benzylamino purine) and NAA (Napthaleneacetic acid). The range of concentrations was not reported. The authors reported $10 \%$ seed germination on $1 / 4$ strength MS alone and $28 \%$ when the seeds were treated with GA (gibberellic acid). No concentration or time is given for the GA treatment. Seeds were also given a 30-day cold pretreatment at $4^{\circ} \mathrm{C}$ on the MS medium. Cold treated seeds gave $90 \%$ germination at room temperature without treatment with GA.

Culture of in vitro explants from mature plants was not successful because of ineffective surface sterilization or death of the tissue. Contamination rates of surface decontaminated seeds and explant tissues are not given.

Further assays were completed using sterile leaves from in vitro germinated seedlings. Length of culture times was not given. Excised leaves subcultured on $1 / 4$ strength MS alone produced a few adventitious buds. The authors reported that these buds formed on both the lamina and petiole segments of the explanted tissue. The number of buds increased when the medium was supplemented with BAP or NAA but the concentrations leading to the increase are not reported. However, they did report that more than 20 buds per explant were obtained using $10^{-5} \mathrm{M}$ BAP with or without NAA. Only roots were formed in the presence of $10^{-5} \mathrm{MNAA}$ and low concentrations of BAP; no time spans were given for the appearance of the buds. Finally, the authors reported that in most of the hormonal combinations the newly formed buds initiated roots a few days after their first appearance. While no histological photographs or drawings are shown, they reported that roots were well 
connected with the shoots and complete plantlets were able to develop on the $1 / 4$ strength MS medium alone.

Bobak et al., (1989) -Histological studies of organogenesis in the leaves of Drosera spathulata L. in vitro were presented. Seeds were greenhouse harvested and surface sterilized in $2.5 \%$ chloramine for $15 \mathrm{~min}$ followed by several washes with sterile distilled water. The seeds were germinated in petri dishes containing MS medium and charcoal. The strength of the MS medium and the amount of charcoal added were not reported. Seeds were cold treated at $4^{\circ} \mathrm{C}$ for 30 days before cultivation. It is not clear if this cold treatment preceded or followed surface sterilization and plating on the MS medium. Following 80 days of cultivation, sterile leaves were removed from the plants and placed on a modified medium (MS, 1962) with added grapevine exudates (5\%). The authors do not give any references for the preparation of the exudate. Leaves were sampled periodically at $6,9,15$ and 21 days for developing organoids (this term is taken to mean new shoot meristematic regions). Tissue was prepared for both TEM and light microscopy. They reported that visual observations of the tissue on day six revealed no apparent changes. However, serial sections of the tissue revealed that cell division had already begun to take place in specific regions at an earlier time.

They reported the formation of large clusters of dividing cells located in the inner portions of the explant tissue that may be associated with, or lying close to, the vascular system. These cells are described as being highly vacuolate with a welldefined nucleus. They also describe cells entering into the division process that are 
highly reminiscent of cells found in shoot apical meristems. That is, they apparently have a high affinity for cytological stains and show an increased accumulation of starch. These centers of division are reported to arise as a proliferation of parenchymatous tissue and may include the cells of the subepidermal layer. The authors state that by day 21 these regions have given rise to protuberances that upon histological examination possess distinctly differentiated shoot meristematic apices and leaf primordial. With continued culture, complete plants were regenerated that were able to live under normal conditions (normal conditions are not defined). 
Reference:

Rathore, T.S., Tandon, P. \& Shekhawat, N.S. (1991). In vitro regeneration of pitcher plant (Nepenthes khasiana Hook. f.) - a rare insectivorous plant of India. Journal of Plant Physiology, 139, 246-248.

\section{In Vitro Germination of Seeds}

Surface sterilization protocol:

1) Wash several times with tap water and a few drops of Tween 80.

2) Surface sterilize with $0.1 \%(\mathrm{w} / \mathrm{v})$ mercuric chloride for 2-3 minutes.

3) Wash with sterile $\mathrm{H}_{2} \mathrm{O}$.

4) Soak in sterile water for 3-4 hours.

5) Submerge in $70 \%$ ethanol for 20 seconds.

6) Rinse with sterile water.

7) Inoculate on germination medium.

Germination medium:

1) $1 / 2$ strength Murashige and Skoog (1962)

2) $0.1 \mathrm{MG} / \mathrm{L}$ IAA

3) $0.5 \mathrm{mg} / \mathrm{l} \mathrm{kinetin}$

4) $2.0 \mathrm{mg} / 1 \mathrm{GA} 3$

5) $20 \mathrm{~g} / \mathrm{l}$ sucrose

6) Adjust $\mathrm{pH}$ of medium to 5.8 before adding agar.

7) $8.0 \mathrm{~g} / \mathrm{l}$ agar

8) Store cultures under diffuse light at $26+/-2$ degrees Celsius.

9) Use 6-8 week-old seedlings far nodal and apical shoot explants $(1.0-1.5 \mathrm{~cm}$ explant length).

10) Transfer explants to multiplication medium.

Multiplication medium:

1) Full strength MS medium

2) $0.1 \mathrm{mg} / 1$ IAA

3) $2.0 \mathrm{mg} / 1 \mathrm{BAP}$

4) $50.0 \mathrm{mg} / 1$ ascorbic acid

5) $25.0 \mathrm{mg} / \mathrm{l}$ citric acid

6) $50.0 \mathrm{mg} / \mathrm{l}$ arginine

7) $25.0 \mathrm{mg} / \mathrm{l}$ adenine sulfate

8) $500.0 \mathrm{mg} / \mathrm{l} \mathrm{charcoal}$

9) $500.0 \mathrm{mg} / 1$ polyvinylpyrrolidone 
10) Adjust $\mathrm{pH}$ of medium to 5.8 before adding agar.

11) $8.0 \mathrm{~g} / \mathrm{l}$ agar

12) Keep cultures in the dark for 3-4 days.

13) Transfer to light conditions of 2500 lux light intensity for 12 hours photoperiod at $26 \pm 2{ }^{\circ} \mathrm{C}$.

14) After 4 weeks growth, differentiated shoots may be subcultured for further multiplication or transplanted to rooting medium.

Rooting Medium:

1) $1 / 2$ strength MS medium

2) $2.0 \mathrm{mg} / 1 \mathrm{NAA}$

3) $0.1 \mathrm{mg} / \mathrm{l} \mathrm{kinetin}$

4) $20 \mathrm{~g} / \mathrm{l}$ sucrose

5) Adjust $\mathrm{pH}$ to 5.8 before adding agar.

6) $8.0 \mathrm{~g} / \mathrm{l}$ agar

7) Store cultures in the dark for 1 week.

8) Transfer to light conditions of 2500 lux light intensity at $26+-2$ degrees Celsius.

9) Transfer to strengthening medium for faster growth and development of pitchers.

10) Approximately $80 \%$ of the plantlets should develop roots.

Strengthening and pitcher development medium:

1) $1 / 4$ strength MS medium (hormone-free)

2) $20 \mathrm{~g} / \mathrm{l}$ sucrose

3) Adjust $\mathrm{pH}$ of medium to 5.8 prior to addition of agar.

4) $6 \mathrm{~g} / \mathrm{l}$ agar

5) Light and temperature conditions as above.

6) When plantlets are approximately 5-7 inches in length with well developed roots, remove from flasks, wash thoroughly with tap water followed by sterile distilled water, and then transfer to pots containing vermiculite and drained soil (3:1)

7) Harden in a growth chamber.

8) Within 4-5 weeks, potted plants should develop pitchers with normal lids.

\section{Additional Notes}

Nodal shoot segments were found to produce the most multiple shoots (10-12). Apical shoot explants produced only 6-8 new shoots. Ascorbic acid, citric acid, arginine and adenine sulfate enhanced shoot production (12-15 per explant) when added to the multiplication medium. If they were not added the cultures declined in growth and gradually deteriorated. Leaf and root explants did not produce shoots or callus. Hardening before transplantation to a growing medium was essential. 


\section{MICROPROPAGATION OF DROSERA ROTUNDIFOLIA - PRODUCTION OF ADVENTITIOUS BUDS}

Reference:

Bobak, M., Blehova, A., Kristin, J., Ovecka, M., \& Samaj, J. (1995). Direct plant regeneration from leaf explants of Drosera rotundifolia cultured in vitro. Plant Cell, Tissue and Organ Culture, 43, 43-49.

Explant source:

Leaves from aseptically grown plantlets of $D$. rotundifolia. The authors neither state nor reference a protocol for the production of the aseptic plantlets. However, see Anthony (1992) and Burgher (1961). The authors report that the source plants were grown on MS medium (Murashige and Skoog, 1962) with a 16-hour photoperiod (PPF of $32 \mathrm{uM} / \mathrm{m} 2 / \mathrm{s}$ ) under cool white fluorescent bulbs at a temperature of $24 \pm 2^{\circ} \mathrm{C}$.

Medium for the induction of adventitious buds:

The authors reported testing 49 different media formulations and report best production occurred on liquid MS medium with $10-8 \mathrm{M}$ of NAA (18.4 plantlets per explant). Solidified MS medium without growth regulators produced approximately 7 adventitious buds per leaf explant.

1) Full strength MS medium (basal salts)

2) $30 \mathrm{~g} / \mathrm{l}$ sucrose

3) $100 \mathrm{mg} / \mathrm{l}$ myo-inositol

4) Adjust the $\mathrm{pH}$ to 5.8 before adding agar or use liquid medium (for liquid induction medium add $10-8 \mathrm{M}$ of NAA).

5) $7 \mathrm{~g} / \mathrm{l} \mathrm{agar}$

Medium for the induction of callus:

1) Full strength MS medium and supplements as above for solid medium plus $10^{-6}$ or $5 \times 10^{-6} \mathrm{M}$ of BA

2) Place in light and temperature conditions as outlined under Protocol.

Protocol for the generation of adventitious buds:

1) Transfer leaves excised from aseptically cultured plants to either solidified MS medium with no growth regulators (abaxial side in contact with the medium) or to liquid MS medium supplemented with $10^{-8} \mathrm{M}$ of NAA.

2) Place liquid medium cultures on a gyratory shaker at $120 \mathrm{rpm}$. 
3) Maintain both liquid and solid media with a 16-hour photoperiod under cool white fluorescent lights with a PPF of $32 \mathrm{umol} / \mathrm{m}^{2} / \mathrm{s}(400-700 \mathrm{~nm})$.

4) Maintain solid and/or liquid cultures at $24 \pm 2{ }^{\circ} \mathrm{C}$.

\section{Additional Notes}

A change in the leaf pigmentation from green to dark red or red to dark red occurred two days after culture initiation. Media supplemented with 0 to $2 \times 10^{-5} \mathrm{M}$ NAA induced intensive red pigment formation with some necrosis after 28 days in culture. Optimal callus formation and proliferation occurred in the light only on medium containing $10^{-6}$ or $5 \times 10^{-6} \mathrm{M} \mathrm{BA}$. The callus formed was light green and very compact. Full strength, solidified MS medium without hormones produced the most direct shoot formation of all solidified formulations tested. Buds were observed to form on the whole leaf surface, but in particular near the tentacles. 


\section{MICROPROPAGATION OF DROSERA SPATHULATA \\ SHOOT TIP CULTURE \\ INDUCTION OF IN VITRO FLOWERING}

Reference:

Perica, M.C \& Berljak, J. (1996). In vitro growth and regeneration of Drosera spathulata Labill. on various media. HortScience, 31, 1033-1034.

Initial explant material: - surface disinfested shoot tips.

Protocol for surface sterilization of shoot tips:

1) Excise shoot tips 4-6 $\mathrm{mm}$ in length from greenhouse-cultivated plants $(>2.5 \mathrm{~cm}$ in diameter).

2) Cut off leaves and excise shoot apices.

3) Surface-sterilize excised shoot apices in $1.0 \%$ sodium hypochlorite $(\mathrm{SH})$ plus one drop of Tween 20 surfactant for 5 minutes (higher concentrations of SH caused explants to turn brown and decay, as did ETOH dips).

4) Rinse three times ( 3 minutes each) in sterile distilled water.

5) Inoculate separately on full-strength MS medium (Murashige and Skoog, 1962 ) in glass culture tubes containing $10 \mathrm{ml}$ of medium.

6) Maintain cultures with a 16-hour photoperiod under cool white fluorescent lights $(40 \mathrm{umol} \mathrm{m} / \mathrm{s})$ and at a temperature of $24 \pm 2^{\circ} \mathrm{C}$.

7) Subculture after 3 months (each tube should contain 100-200 plantlets).

Medium preparation:

1) Full-strength MS medium including vitamins

2) $30 \mathrm{~g} / \mathrm{l} \mathrm{sucrose}$

3) Adjust $\mathrm{pH}$ to 5.7 with $\mathrm{NaOH}$ before autoclaving.

4) $8.0 \mathrm{~g} / \mathrm{l}$ agar

Subculture:

The authors state that it was not necessary to use the usual 3-stage propagation system for shoot induction, multiplication and rooting. They observed that medium without a growth regulator was best for regeneration and multiplication. Plants rooted spontaneously on this medium. Leaves from regenerated shoots may also be subcultured to fresh medium for adventitious bud induction and subsequent development of shoots. However, regeneration occurred 2 weeks later than when whole plants were subcultured. 
Induction of flowering:

Plants can be induced to flower by subculturing to $1 / 4$ strength MS medium supplemented with $0.12 \mathrm{uM}$ IBA plus $0.44 \mu \mathrm{M} \mathrm{BA}$. This medium reportedly induced $100 \%$ flowering. Plants subcultured from $1 / 4$ strength MS medium at $\mathrm{pH} 5.7$ to $1 / 4$ strength MS medium at $\mathrm{pH} 4.0$ obtained the largest diameter (in 8 weeks subsequent growth) in comparison to plants subcultured to $1 / 4$ strength media at higher $\mathrm{pH}$ values. 


\section{MICROPROPAGATION OF \\ DROSERA ROTUNDIFOLIA, D. CAPENSIS AND D. BINATA \\ ADVENTITIOUS PLANTLET FORMATION FROM \\ EXPLANTED WHOLE LEAVES}

Reference:

Anthony, L.J. (1992). In vitro propagation of Drosera spp. HortScience, 27, 850 .

Source of explant material: whole leaves excised from greenhouse-cultivated plants.

Surface sterilization of leaves:

Whole leaves were excised and surface disinfested in $10 \%(\mathrm{v} / \mathrm{v})$ Clorox $(0.5 \%$ sodium hypochlorite) with 1 drop of Tween 20 surfactant added to each $50 \mathrm{ml}$ of $10 \%$ Clorox solution. Excised leaves were disinfested for 5 minutes followed by three 5minute rinses in sterile distilled water. Longer time spans (10-20 minutes) in the disinfestations solution caused extensive tissue damage and lack of regeneration of adventitious plantlets. Anthony states that approximately $75 \%$ of the original cultures contaminated with $95 \%$ of the $D$. rotundifolia cultures were lost to contamination. She suggests that the contamination was due to the presence of symbiotic bacteria and fungi that may play a role in the digestive process (see Chandler and Anderson, 1977).

Medium:

1) $1 / 2$ strength MS medium (Murashige and Skoog, 1962) prepared by diluting full strength MS medium containing vitamins.

2) $30 \mathrm{~g} / \mathrm{l}$ sucrose

3) $0,02 \mathrm{mg} / \mathrm{l} \mathrm{BA}$

4) $0.01 \mathrm{mg} / \mathrm{l} \mathrm{NAA}$

Note: Addition of phytohormones may not be necessary for the induction of adventitious plantlets since Anthony states that on both $1 / 2$ strength MS medium without hormones and $1 / 2$ strength MS medium supplemented with phytohormones, the multiple adventitious plantlets entirely covered the leaf surface. However, hormones were required for the induction of flowering in D. binata.

5) Adjust $\mathrm{pH}$ to 5.7 before adding agar.

6) $8 \mathrm{~g} / \mathrm{l}$ agar

Protocol:

1) Excise whole leaf from plants. 
2) Surface-disinfest in $10 \%(\mathrm{v} / \mathrm{v})$ Clorox plus one drop of Tween 80 surfactant per $50 \mathrm{ml}$ of sterilant solution. Surface sterilize for 5 minutes.

3) Rinse 3 times (5 minutes each) with sterile distilled water.

4) Transfer to $25 \times 150 \mathrm{ml}$ culture tubes containing $20 \mathrm{ml}$ of medium.

5) Maintain cultures at $25^{\circ} \mathrm{C}$ with a 16 -hour photoperiod under fluorescent lights (Philips 40-W Agro-Lite bulbs).

6) Shoots should appear after approximately 4 weeks.

7) For rooting of $D$ rotundifolia and $D$. capensis, subculture adventitious shoots to $1 / 2$ strength MS medium without hormones (Anthony reported the formation of extensive root systems after 6-8 weeks).

8) For rooting of $D$. binata, subculture to $1 / 2$ strength MS medium with hormones as above. Anthony observed that only $10 \%$ of the $D$. binata rooted on medium supplemented with BA and NAA.

Induction of flowering:

Anthony found that about $1 / 2$ of the regenerated plantlets of $D$. rotundifolia and $D$. capensis produced flowers when subcultured to fresh $1 / 2$ strength MS medium with or without hormones. She observed that approximately $90 \%$ of the $D$. binata plantlets flowered when subcultured to $1 / 2$ strength MS medium containing hormones. She did not vary hormonal concentrations. $D$. binata did not produce flowers on media without hormones. 


\section{ASEPTIC GERMINATION AND GROWTH OF DROSERA BINATA}

References:

Chandler, G.E. \& Anderson, J.W. (1967). Studies on the origin of some hydrolytic enzymes associated with the leaves and tentacles of Drosera species and their role in heterotrophic nutrition. New Phytologist, 77, 51-62.

Liddell, R. (1953). Germination of Paphiopediulum. American Orchid Society Bulletin 22:195

Surface sterilization of seeds:

1) Disinfest seeds (seeds four weeks old were used in these experiments) for 15 minutes in a solution of benzalconium chloride $(0.1 \% \mathrm{w} / \mathrm{v})$ and calcium propionate $(18 \mathrm{mM})$.

2) Rinse in sterile distilled water.

3) Transfer to sterile $500 \mathrm{ml}$ flasks containing $180 \mathrm{ml}$ of nutrient medium (Chandler and Anderson used Liddell's orchid germination medium and reported lowering the agar concentration to $0.65 \% \mathrm{w} / \mathrm{v}$ ).

4) Light and temperature conditions were not stated.

5) Following germination (time required not reported), transfer to fresh medium. For purposes of their experiments Chandler and Anderson transferred 1 seedling per $500 \mathrm{ml}$ flask.

6) For growth, maintain cultures at $20^{\circ} \mathrm{C}$ under fluorescent and Gro-lux tubes (8.5 Wm-2 at the agar surface). Photoperiod not reported.

Liddell's orchid germination medium:

$\begin{array}{ll}\mathrm{Ca}\left(\mathrm{NO}_{3}\right) 2 \cdot 4 \mathrm{H}_{2} \mathrm{O} & 1.00 \mathrm{~g} / 1 \\ \mathrm{NH}_{4} \mathrm{NO}_{3} & 0.25 \mathrm{~g} / 1 \\ \mathrm{MgSO}_{4} \cdot 7 \mathrm{H}_{2} \mathrm{O} & 0.25 \mathrm{~g} / 1 \\ \mathrm{KH}_{2} \mathrm{PO}_{4} & 0.20 \mathrm{~g} / 1 \\ \mathrm{~K}_{2} \mathrm{HPO}_{4} & 0.10 \mathrm{~g} / 1\end{array}$

To each liter of medium add $5 \mathrm{ml}$ of the following stock solution:

6.0 g citric acid. $1 \mathrm{H}_{2} \mathrm{O}$

$1.25 \mathrm{~g} \mathrm{FeSO}_{4} .7 \mathrm{H}_{2} \mathrm{O}$

$0.25 \mathrm{MNSO}_{4} \cdot \mathrm{H}_{2} \mathrm{O}$

$500 \mathrm{ml}$ distilled water

Liddell also added $20 \mathrm{~g}$ of sugar consisting of $90 \%$ glucose and $10 \%$ sucrose per liter. The $\mathrm{pH}$ was adjusted to 5.0. Agar concentration was $1.75 \%$. 


\section{IN VITRO CULTURE OF EMBRYOS OF DROSOPHYLLUM LUSITANICUM}

Reference:

Dore, J., Swamy, R., \& Mohan Ram, H.Y. (1967). Cultivation of embryos of Drosophyllum lusitanicum Link, an insectivorous plant. Experimentia, $\underline{19}, 363-371$.

Note: This is a very early paper in the history of carnivorous plant tissue culture. However, it contains information regarding techniques, media formulations and experimental results that may be useful in designing future tissue culture experiments.

Outline of experiments:

1) Seeds were surface sterilized with chlorine water (specifics not reported), embryos were excised under aseptic conditions and planted on various media.

2) The media employed were:

Basal medium $=$ modified White's medium $+2 \%$ sucrose $+0.8 \%$ agar .

Medium \#1 = basal medium

Medium $\# 2$ = basal medium + casein hydrolysate

Medium \#3 = basal medium + casein hydrolysate + IAA (1ppm)

Medium \#4 = basal medium + casein hydrolysate + coconut milk $(15 \% \mathrm{v} / \mathrm{v})$

Medium \#5 = basal medium + kinetin $(1 \mathrm{ppm})$

Medium $\# 6$ = basal medium + yeast extract $(500 \mathrm{mg} / \mathrm{l})$

3) Embryos cultured on Medium \#1, Medium \#2, Medium \#3 and Medium \#6 germinated and produced seedlings after 6-8 weeks of culture. The roots were well developed and the plantlets attained a height of $7-8 \mathrm{~cm}$ in 10 weeks.

Flowering was not observed.

4) Embryos cultured on Medium \#5 formed highly condensed, succulent shoots. Leaf bases were fleshy and adhered to the stem. No roots developed.

5) Embryos cultured on Medium \#4 did not germinate, but formed proliferating dark brown, friable callus after 10 weeks of culture. Patches of pearly white tissue appeared on these brown calli.

6) The white tissue was excised from these calli and subcultured on Medium \#4 and basal medium + casein hydrolysate + kinetin $(1 \mathrm{ppm})+$ IAA $(1 \mathrm{ppm})$. Active cell division occurred in both media.

7) Approximately $12 \%$ of the subcultures on Medium \#4 differentiated into shoots and roots after two weeks of subculture. 
White's medium:

Macronutrients $=\mathrm{KNO}_{3}(80 \mathrm{mg} / \mathrm{l}) ; \mathrm{MgSO}_{4} \cdot 7 \mathrm{H}_{2} \mathrm{O}(737 \mathrm{mg} / \mathrm{l}) ; \mathrm{NaH}_{2} \mathrm{PO}_{4} \cdot \mathrm{H}_{2} \mathrm{O}(19$ $\mathrm{mg} / \mathrm{l}) ; \mathrm{Ca}\left(\mathrm{NO}_{3}\right) 2 \cdot 4 \mathrm{H}_{2} \mathrm{O}(288 \mathrm{mg} / \mathrm{l}) ; \mathrm{KCl}(65 \mathrm{mg} / \mathrm{l}) ; \mathrm{NaSO}_{4}(200 \mathrm{mg} / \mathrm{l})$.

Micronutrients $=\mathrm{Kl}(0.75 \mathrm{mg} / \mathrm{l}) ; \mathrm{H}_{3} \mathrm{BO}_{3}(1.5 \mathrm{mg} / \mathrm{l}) ; \mathrm{MnSO}_{4} \cdot 4 \mathrm{H}_{2} \mathrm{O}(6.65 \mathrm{mg} / \mathrm{l})$; $\mathrm{ZnSO}_{4} \cdot 7 \mathrm{H}_{2} \mathrm{O}(2.67 \mathrm{mg} / \mathrm{l}) ; \mathrm{MoO}_{3}(0.0001 \mathrm{mg} / \mathrm{l}) ; \mathrm{CuSO}_{4} \cdot 5 \mathrm{H}_{2} \mathrm{O}(0.001 \mathrm{mg} / \mathrm{l}) ; \mathrm{Fe}\left(\mathrm{SO}_{4}\right) 3$ $(2.5 \mathrm{mg} / \mathrm{l})$.

The above formulation of White's medium is from Handbook of Plant Cell Culture Vol. 1. Edited by D.A. Evans, W.R. Sharp, P.V. Ammirato and Y. Yamada. Macmillan Publishing Company. Copyright 1983. See also Singh, M. and Krikorian, A.D. (1981). White's Standard Nutrient Solution. Annals of Botany 47: 133-139. 


\section{MICROPROPAGATION OF PINGUICULA MORANENSIS}

References:

Adams II, R.M., Koenigsberg, S.S., \& Langhans, R.W. (1979b). In vitro propagation of the butterwort Pinguicula moranensis h.b.k. HortScience, 14, 701-702.

Linsmaier, E. \& Skoog, F. (1965). Organic growth factor requirements of tobacco tissue cultures. Physiologia Plantarum, 185, 100-127.

Source of explant: whole leaves.

\section{Micropropagation Protocol}

Surface sterilization of explants:

1) Excise whole leaves from stock plants.

2) Shake for five minutes in $0.1 \%$ Tween 20 surfactant with 3 changes of the solution during this time span (vacuum aspirate and replace with fresh solution).

3) Replace solution with $1 \%$ Physan 20 (10\% n-alkyl dimethyl benzyl ammonium chloride $+10 \%$ n-alkyl dimethyl ethylbenzyl ammonium chloride) and shake for 5 minutes with 3 changes of solution.

4) Replace solution with $10 \%$ Clorox ( $0.525 \%$ sodium hypochlorite) with $0.1 \%$ Tween 20 surfactant. Shake for five minutes with changes of the sterilant solution.

5) Rinse three times with sterile distilled water.

Note: Succulent winter leaves survive disinfestations much better than summer leaves. Both leaf forms give rise to adventitious plantlets equally well.

Aseptic culture:

1) Transfer surface disinfested leaves to culture tubes or flasks containing Linsmaier-Skoog (1965) medium with all salts, thiamine and inositol at $1 / 5$ strength, $0.02 \mathrm{mg} / 1 \mathrm{BA}, 0.01 \mathrm{mg} / \mathrm{l} \mathrm{NAA}, 30 \mathrm{~g} / \mathrm{l}$ sucrose.

2) Adjust $\mathrm{pH}$ of medium to 6.5 before adding agar.

3) $6 \mathrm{~g} / \mathrm{l} \mathrm{agar}$

4) Leaves cultured on this medium should produce 7-8 plantlets with roots on each leaf explant in approximately 8 weeks. 
Subculture:

1) For a higher yield of plantlets, subculture the leaves to $1 / 5$ strength LinsmaierSkoog medium containing $2.0 \mathrm{mg} / \mathrm{l} \mathrm{BA}$ and $1.0 \mathrm{mg} / 1 \mathrm{NAA}$ for $3-4$ weeks. This results in additional adventitious bud formation.

2) To maximize the growth of each plantlet, subculture again on $1 / 5$ strength Linsmaier-Skoog medium with a reduced hormone level $(0.02 \mathrm{mg} / \mathrm{l} \mathrm{BA}$ and $0.01 \mathrm{mg} / \mathrm{l} \mathrm{NAA}$ ).

3) Acclimatize the plantlets by planting in limed, sterilized sphagnum moss. Gradually reduce the relative humidity from $100 \%$ to $50 \%$ over a period of 4 weeks.

Note: Linsmaier-Skoog medium contains the same macronutrient and micronutrient salts as Murashige and Skoog (1962) medium and differs only in its vitamin composition. Linsmaier and Skoog increased the level of thiamine four-fold from the original MS formulation. Nicotinic acid and pyridoxine were found unnecessary and eliminated from the composition of vitamin mixture. 
Table No.1 Taxonomic Classification of Carnivorous Plants

Kingdom - Planate

Division - Magnoliophyta

Class - Chloripetalae

\begin{tabular}{|c|l|l|c|}
\hline \multicolumn{1}{|c|}{ Order } & \multicolumn{1}{|c|}{ Family } & \multicolumn{1}{c|}{ Genus } & *No. of Species \\
\hline Sarraceniales & Sarraceniaceae & Darlingtonia & 1 \\
\hline & & Heliamphora & 6 \\
\hline & & Sarracenia & 9 \\
\hline Nepenthales & Droseraceae & Drosera & $90-100+$ \\
\hline & & Drosophyllum & 1 \\
\hline & & Dionaea & 1 \\
\hline & & Aldrovanda & 1 \\
\hline & Nepenthaceae & Nepenthes & 70 \\
\hline Saxifragales & Cephalotaceae & Cephalotus & 1 \\
\hline & Byblidaceae & Byblis & 2 \\
\hline Violales & Dioncophyllaceae & Triphyophyllum & 1 \\
\hline
\end{tabular}

Division - Magnoliophyta

Class - Sympetalae

\begin{tabular}{|c|l|l|c|}
\hline \multicolumn{1}{|c|}{ Order } & \multicolumn{1}{|c|}{ Family } & \multicolumn{1}{c|}{ Genus } & *No. of Species \\
\hline Bromeliales & Bromeliaceae & Brocchinia & 2 \\
\hline & & Catopsis & 1 \\
\hline Scrophulariales & Lentibulariaceae & Pinguicula & 35 \\
\hline & & Utricularia & 280 \\
\hline & & Genlesia & 35 \\
\hline & & Polyphompholyx & 2 \\
\hline & & Biovularia & 1 \\
\hline & Martynaceae & Ibicella & 1 \\
\hline
\end{tabular}

* Approximate number of species (from Givnish, 1989; Cheers, 1992). 


\begin{tabular}{|c|c|c|c|c|}
\hline Genus & Species & Explant Tissue & Comments & Reported by \\
\hline \multirow[t]{2}{*}{ Drosera } & pygmaea & & & Harder (1964) \\
\hline & natelensis & $\begin{array}{l}\text { Mature leaves, young } \\
\text { unopened shoots, } \\
\text { flower buds, flower } \\
\text { stalks, and roots from } \\
\text { field collected plants }\end{array}$ & $\begin{array}{l}\text { Report } \\
\text { embryogenesis in } \\
\text { all explant } \\
\text { sources except the } \\
\text { root which they } \\
\text { were unable to } \\
\text { decontaminate }\end{array}$ & Crouch and van Staden (1987) \\
\hline \multirow[t]{8}{*}{ Drosera } & rotundifolia & $\begin{array}{l}\text { leaves from } \\
\text { aseptically grown } \\
\text { plants }\end{array}$ & $\begin{array}{l}\text { Report } \\
\text { embryogenic } \\
\text { callus }\end{array}$ & Samaj et al. (1995) \\
\hline & rotundifolia & Aseptic seedlings & & Bonnet et al. (1984) \\
\hline & rotundifolia & Aseptic seedlings & & Simola (1978a) \\
\hline & rotundifolia & $\begin{array}{l}\text { Aseptic seedlings } \\
\text { produced in Simola } \\
\text { experiments (1978a) }\end{array}$ & & Simola (1978b) \\
\hline & rotundifolia & $\begin{array}{l}\text { Leaves from } \\
\text { aseptically grown } \\
\text { plants }\end{array}$ & & Bobak et al. (1995) \\
\hline & rotundifolia & & & Kulczanka and Cznsika (1987) \\
\hline & rotundifolia & Whole leaves & & Anthony (1992) \\
\hline & spathulata & $\begin{array}{l}\text { Leaves from } \\
\text { aseptically grown } \\
\text { plants }\end{array}$ & & Bobak et al. (1989) \\
\hline
\end{tabular}




\begin{tabular}{|c|c|c|c|c|}
\hline Genus & Species & Explant Tissue & Comments & Reported by \\
\hline \multirow[t]{2}{*}{ Drosera } & pygmaea & & & Harder (1964) \\
\hline & natelensis & $\begin{array}{l}\text { Mature leaves, young } \\
\text { unopened shoots, } \\
\text { flower buds, flower } \\
\text { stalks, and roots from } \\
\text { field collected plants }\end{array}$ & $\begin{array}{l}\text { Report } \\
\text { embryogenesis in } \\
\text { all explant } \\
\text { sources except the } \\
\text { root which they } \\
\text { were unable to } \\
\text { decontaminate }\end{array}$ & Crouch and van Staden (1987) \\
\hline \multirow[t]{8}{*}{ Drosera } & rotundifolia & $\begin{array}{l}\text { leaves from } \\
\text { aseptically grown } \\
\text { plants }\end{array}$ & $\begin{array}{l}\text { Report } \\
\text { embryogenic } \\
\text { callus }\end{array}$ & Samaj et al. (1995) \\
\hline & rotundifolia & Aseptic seedlings & & Bonnet et al. (1984) \\
\hline & rotundifolia & Aseptic seedlings & & Simola (1978a) \\
\hline & rotundifolia & $\begin{array}{l}\text { Aseptic seedlings } \\
\text { produced in Simola } \\
\text { experiments (1978a) }\end{array}$ & & Simola (1978b) \\
\hline & rotundifolia & $\begin{array}{l}\text { Leaves from } \\
\text { aseptically grown } \\
\text { plants }\end{array}$ & & Bobak et al. (1995) \\
\hline & rotundifolia & & & Kulczanka and Cznsika (1987) \\
\hline & rotundifolia & Whole leaves & & Anthony (1992) \\
\hline & spathulata & $\begin{array}{l}\text { Leaves from } \\
\text { aseptically grown } \\
\text { plants }\end{array}$ & & Bobak et al. (1989) \\
\hline
\end{tabular}




\begin{tabular}{|c|c|c|c|c|}
\hline Genus & Species & Explant Tissue & Comments & Reported by \\
\hline \multirow[t]{4}{*}{ Drosera } & spathulata & $\begin{array}{l}\text { Leaves from } \\
\text { aseptically grown } \\
\text { plants }\end{array}$ & $\begin{array}{l}\text { Report } \\
\text { callogenesis }\end{array}$ & Blehova et al. (1992) \\
\hline & spathulata & Shoot tips & & Perica and Berljak (1996) \\
\hline & spathulata & $\begin{array}{l}\text { Leaves from } \\
\text { aseptically grown } \\
\text { plants }\end{array}$ & $\begin{array}{l}\text { Studied plastid } \\
\text { morphogenesis }\end{array}$ & Bobak et al. (1996) \\
\hline & spathulata & $\begin{array}{l}\text { Leaves from } \\
\text { aseptically grown } \\
\text { plants }\end{array}$ & $\begin{array}{l}\text { Report callus } \\
\text { induction }\end{array}$ & Bobak et al. (1993) \\
\hline Drosophyllum & lusitanicum & $\begin{array}{l}\text { Seeds, excised } \\
\text { embryos }\end{array}$ & $\begin{array}{l}\text { Report of embryo } \\
\text { culture }\end{array}$ & Swamy and Ram (1967) \\
\hline Genlesia & & & & not reported \\
\hline Heliamphora & & & & not reported \\
\hline Ibicella & & & & not reported \\
\hline \multirow[t]{2}{*}{ Nepenthes } & khasiana & $\begin{array}{l}\text { Aseptic seedlings, } \\
\text { leaf tissue, nodal } \\
\text { cuttings, shoot apices, } \\
\text { and root segments }\end{array}$ & & Rathore et al. (1991) \\
\hline & $\begin{array}{l}1 / 2 \text { of known } \\
\text { species of } \\
\text { Nepenthes }\end{array}$ & & & $\begin{array}{l}\text { Redwood and Bowling (1990) } \\
\text { Kew Gardens }\end{array}$ \\
\hline \multirow[t]{2}{*}{ Pinguicula } & moranensis & Whole leaves & & Adams et al. (1979a) \\
\hline & lusitanica & & & Harder and Zemlis (1967) \\
\hline Polyphompholyx & & & & not reported \\
\hline \multirow[t]{2}{*}{ Sarracenia } & purpurea & Immature seed & & Withner (1964) \\
\hline & flava & Immature seed & & Withner (1964) \\
\hline
\end{tabular}




\begin{tabular}{|l|l|l|l|l|}
\hline Genus & Species & Explant Tissue & Comments & Reported by \\
\hline Triphyophylum & flava & $\begin{array}{l}\text { Seeds, axenic } \\
\text { seedlings }\end{array}$ & & Bringmann and Rischer (2001) \\
\hline Utricularia & exoleta & Nodal segments & & $\begin{array}{l}\text { Pringsheim and Pringsheim } \\
(1962)\end{array}$ \\
\hline & inflexa & Stolon segments & & Swamy and Ram (1971) \\
\hline & inflexa & Ripe fruits & & Swamy and Ram (1969) \\
\hline
\end{tabular}




\section{Literature Cited}

Adamec, L. (1997). Mineral nutrition of carnivorous plants: A review. The Botanical Review, 63, 273-299.

Adams II, R.M., Koenigsberg, S.S., \& Langhans, R.W. (1979a). In vitro propagation of Cephalotus follicularis (Australian pitcher plant). HortScience, 14, 512-513.

Adams II, R.M., Koenigsberg, S.S., \& Langhans, R.W. (1979b). In vitro propagation of the butterwort Pinguicula moranensis h.b.k. HortScience, 14, 701-702.

Anthony, L.J. (1992). In vitro propagation of Drosera spp. HortScience, 27, 850.

Beebe, J.D. (1980). Morphogenetic responses of seedlings and adventitious buds of the carnivorous plant Dionaea muscipula in aseptic culture. Botanical Gazette, 141, 396-400.

Baskin, C.C. \& Baskin, J.M. (1998). Seeds; ecology, biogeography, and evolution of dormancy and germination. San Diego, CA. Academic Press.

Beeckman, T., De Rycke, R., Viane, R., \& Inze, D. (2000). Histological study of seed coat development in Arabidopsis thaliana. Journal of Plant Research, 113, 139-148.

Bewley, J.D. \& Black, M. (1994). Seeds - Physiology, Development and Germination $\left(2^{\text {nd }}\right.$ ed. $)$. New York, London. Plenum Press.

Blehova, A., Erdelsky, K., \& Bobak, M. (1992). Cultivation of organ and callus culture of Drosera spathulata Labill. in in vitro conditions. Physiologia Plantarum 27, 93101.

Bobak, M., Blehova, A., \& Erdelsky, K. (1989). Histological and cytological study of early phases of organogenesis on excised leaves of Drosera spathulata L. cultivated in vitro. Biologia, 44, 795-792.

Bobak, M., Blehova, A., Cholvadova, B., \& Somsakova, V. (1990). Morphogenesis of the plastid apparatus in the process of organogenesis at the leaves of the sundew (Drosera spathulata L.), cultivated in in vitro conditions. Physiologia Plantarum, $25,33-41$.

Bobak, M., Blehova, A., Kristin, J., Ovecka, M., \& Samaj, J. (1995). Direct plant regeneration from leaf explants of Drosera rotundifolia cultured in vitro. Plant Cell, Tissue and Organ Culture, 43, 43-49. 
Bobak, M., Blehova, A., Samaj, J., \& Ovecka, M. (1993). Studies of organogenesis from the callus culture of the sundew (Drosera spathulata Labill.). Plant Physiology, 142, 251-253.

Bobak, M., Samaj, J., Blehova, A., Ovecka, M., Novomeska, S., \& Kristin, J. (1998). Morphology and ultrastructure of isolated gemmae of Drosera pygmaea and their in vitro germination. Biologia Plantarum, 41, 169-176.

Boulay, J. (1995). Les plantes carnivores, essais de micropropagation. Bulletin des Academie et Societe Lorraines des Sciences, 34, 151-159.

Budzianowski, J. (1995). Naphthoquinones of Drosera spathulata from in vitro cultures. Phytochemistry, 40, 1145-1148.

Budzianowski, J. (1996). Naphthohydroquinone glucosides of Drosera rotundifolia and D. intermedia from in vitro cultures. Phytochemistry, 4, 1145-1147.

Budzianowski, J. (1997). 2-methylnaphthazarin 5-O-glucoside from the methanol extracts of in vitro cultures of Drosera species. Phytochemistry, 44, 75-77.

Budzianowski, J. (2000). Naphthoquinone glucosides of Drosera gigantea from in vitro cultures. Planta Medica, 66, 667-669.

Burgher, R.M.(1961). Axenic seedlings of Drosera. Nature, 191, 724-725.

Chandler, G.E. \& Anderson, J.W. (1967). Studies on the origin of some hydrolytic enzymes associated with the leaves and tentacles of Drosera species and their role in heterotrophic nutrition. New Phytologist, 77, 51-62.

Cheers, G. (1992). A Guide to Carnivorous Plants of the World. New York. Angus \& Robertson, Harper Collins Publishers.

Crouch, I.J., Finnie, J.F., \& van Staden, J. (1990.) Studies on the isolation of plumbagin from in vitro and in vivo grown Drosera species. Plant Cell, Tissue and Organ Culture, 21, 79-82.

Crouch, I.J. \& van Staden, J. (1987). In vitro propogation of Drosera natalensis. $\underline{\text { South }}$ African Journal of Botany, 54, 94-95.

Dore, J., Swamy, R., \& Mohan Ram, H.Y. (1967). Cultivation of embryos of Drosophyllum lusitanicum Link, an insectivorous plant. Experimentia, 19, 363371. 
Dore, J., Swamy, R., \& Mohan Ram, H.Y. (1969). Studies on growth and flowering in axenic cultures of insectivorous plants. I. Seed germination and establishment of utricularia inflexa. Phytomorphology, 19, 363-371.

Dore, J., Swamy, R., \& Mohan Ram, H.Y. (1971). Studies on the growth and flowering in axenic cultures of insectivorous plants. II. Induction of flowering and development of flower in Utricularia inflexa. Zeitschrift fur Pflanzenphysiologie, 65, 315-325.

Givnish, T.J. (1989). Ecology and evolution of carnivorous plants. In W. G. Abrahamson. Plant-Animal Interactions. (pp. 243-290). New York. McGraw-Hill Inc.

Harder, R. (1964). Vegetative entwicklung und blutenbildung in axenischen kulturen der insektivore Drosera pygmaea Dc. Planta, 63, 316-325.

Harder, R. \& Zemlin, I. (1967). Forderung der entwicklung und des bluhens von Pinguicula lusitanica durch futterung in axenischer kultur. Planta (Berl.), 73, 181193.

Lichtscheidl, I.K., Lancelle, S.A., \& Hepler, P.K. (1990). Actin-endoplasmic reticulum complexes in Drosera. Protoplasma, 155, 116-126.

Liddell, R. (1953). Germination of Paphiopediulum. American Orchid Society Bulletin $\underline{22}: 195$

Linsmaier, E. \& Skoog, F. (1965). Organic growth factor requirements of tobacco tissue cultures. Physiologia Plantarum, 185, 100-127.

Lloyd, E.F. (1942). The Carnivorous Plants. Waltham, Massachusetts. Chronica Botanica Co.

Miles, D.H., Kokpol, U., Zalkow, L.H., Steindel, S.J., \& Nabors, J.B. (1974). Preliminary investigation of antitumor activity of Sarracenia flava. Journal of Pharmaceutical Science, 63, 613 .

Minocha, S.C. (1985.) In vitro propagation of Dionaea muscipula. HortScience, 20, 216217.

Munday, R. \& Munday, C.M. (2000). Induction of quinone reductase and glutathione transferase in rat tissues by juglone and plumbagin. Planta Medica, 66, 399-402.

Murashige, T. \& Skoog, F. (1962). A revised medium for rapid growth and bioassays with tobacco tissue culture. Physiologia Plantarum 15, 473-497. 
Parliman, B.J., Evans, P.T., \& Mazur, A.R. (1982). Adventitious bud differentiation and development in leaf cuttings of Dionaea muscipula Ellis ex. 1. (venus fly trap) cultured in vitro. Journal of the American Society of Horticultural Science, 107, 310-316.

Parliman, B.J., Evans, P.T., \& Rupert, E.A. (1982). Tissue culture of single rhizome explants of Dionaea muscipula Ellis ex. 1., the venus fly trap, for rapid asexual propagation. Journal of the American Society of Horticultural Science, 107, 305310 .

Perica, M.C \& Berljak, J. (1996). In vitro growth and regeneration of Drosera spathulata Labill. on various media. HortScience, 31, 1033-1034.

Pringsheim, E.G. \& Pringsheim, O. (1962). Axenic culture of Utricularia. American Journal of Botany, 49, 898-901.

Rathore, T.S., Tandon, P. \& Shekhawat, N.S. (1991). In vitro regeneration of pitcher plant (Nepenthes khasiana Hook. f.) - a rare insectivorous plant of India. Journal of Plant Physiology, 139, 246-248.

Redwood, G. \& Bowling, D. (1990). Micropropagation of Nepenthes species. Botanic Gardens Micropropagation News, 1, 19-20.

Samaj, J., Bobak, M., Blehova, A., Kristin, J., \& Auxtova-Samajova, O. (1995). Developmental SEM observations on an extracellular matrix in embryogenic calli of Drosera rotundifolia and Zea mays. Protoplasma, 186, 45-49.

Sarma, K.S., Maesato, K., Hara, T., \& Sonoda, Y. (1990). Effect of method of agar addition on post-autoclave $\mathrm{pH}$ of the tissue culture media. Annals of Botany, 65 , $37-40$.

Schnell, D.E. (2002). Carnivorous Plants of the United States and Canada $\left(2^{\text {nd }}\right.$ ed.). Portland, Oregon. Timber Press.

Simola, L.K. (1978). Dipeptides as nitrogen sources for Drosera rotundifolia in aseptic culture. Physiology of Plants, 44, 315-318.

Smith, C.M. (1931). Development of Dionaea muscipula II. Germination of seed and development of seed to maturity. Botanical Gazette, 91, 377-394.

Withner, C.L. (1964). Notes on the cultivation of insectivorous plants in vitro. Bulletin of the Torrey Botanical Club, 91, 412-413.

Zenk, M.H., Furbringer, M., \& Steglich, W. (1969). Occurrence and distribution of 7methyljuglone and plumbagin in the Droseraeceae. Phytochemistry, 8, 2199-2200. 


\section{APPENDIX C}

\section{Adventitious or Not?}

This appendix contains some thoughts on the formation of adventitious structures in plants.

Traditionally, and for convenience, plant anatomists and morphologists have considered the primary plant body to be composed of three organs: roots, stems and leaves. The stem, leaves and attendant structures are generally referred to as the shoot system. These organs are seen to arise with a predictable, positional regularity and modularity along the root/shoot axis. In other words, the essential entity in development is the dynamic event. The expression of such an event is the pattern (Harrison, 1992). Any organ that arises outside of this basic developmental model or event sequence/pattern in an abnormal position is termed "adventitious". Gray (1887) termed aerial roots of orchids to be "anomalous" structures. Other early literature makes reference to "morphological roots" to describe roots developing from tissues other than the pericycle of the main root (Ames and McDaniels, 1947). Fahn (1974) describes adventitious structures in plants as "an organ that developed in an unusual position". Raven, Evert and Eichorn (1993) describe the term adventitious as "referring to a structure arising from an unusual place, such as buds at other places than leaf axis, or roots growing from stems and leaves". Whether or not any structure is truly adventitious in nature (that is, arising from an unusual place, and not part of the dynamics of a deeper developmental level of pattern expression) is a fundamental question in plant biology. 
The phenomenon of adventitious development in vascular plants also belongs to that class of morphogenic events usually referred to as regeneration in the classical botanical literature. These phenomena include, but are not limited to, the formation of adventitious roots, shoots, plantlets and somatic embryos.

Regeneration in plants has long been known and studied. It has been broadly defined as the growth of new plant parts after the removal of corresponding parts elsewhere in the plant (Dore, 1955, includes references to early studies and reviews). In view of current biochemical and molecular techniques, and physiological and anatomical interpretations, this definition needs amendment to include organogenesis on the plant body as well as organogenesis, histogenesis and somatic embryogenesis in tissue surgically excised from the plant and grown aseptically in vitro.

Therefore, it is suggested that the term "regeneration" be taken to include any cell division and subsequent differentiation sequence that results in the formation of a complete tissue, organ, plantlet, or somatic embryo or embryo-like structure within either the plant body or tissues excised from the plant and maintained in culture. Such excised tissues are generally termed "explants" (Arditti, 1993).

A confusing number of descriptive terms have accumulated in the literature regarding all aspects of adventitious development. For instance Goebel (1903), in an early review, considered the phenomena of regeneration to imply a development of dormant or latent rudiments, which he termed 'Anlagen'. These Anlagen were already present in the plant, either as dormant, differentiated embryonic tissue - and thus distinguishable either histologically or cytologically from surrounding tissue - or as a tendency or disposition in the tissue toward the formation of new structures. In this latter case, Goebel describes this 
tissue disposition as being outwardly invisible. Ames and McDaniels (1947), in their text on plant anatomy, state that adventitious roots may arise from meristematic root germs or 'cushions' that are cytologically or histologically distinguishable from the surrounding cells; or, in contrast, from groups of cells that are not distinguishable from the surrounding tissue, though they are still capable of forming new structures. These are additional terms for Goebel's 'Anlagen' and 'tissue disposition'. Esau (1967) states that adventitious roots may arise from dormant primordia that had been laid in place earlier in development until stimulated to grow, or from primordia that arise anew in apparently undifferentiated tissue.

Sinnott (1960) in Plant Morphogenesis included a chapter concerning regeneration in higher plants in which he divides regenerative phenomena into three different regenerative activities: reconstitution, which applies to cases of reorganization of embryonic tissue in which the original structure is reformed after having been disrupted (regeneration proper); restoration, whereby missing tissue or organs are replaced by the activity of new meristematic regions arising in adjacent tissues (i.e., the formation of new vascular tissues following wounding); and reproductive regeneration, which includes the formation of a new plant or plants from tissues or organs separated from the plant body. Sinnott states that in restoration the missing tissues or organs are replaced by the activation of dormant buds or primordia already present in the tissue, or from the formation of new buds. These primordia, and the formation of primordia de novo are another reference to Goebel's 'Anlagen' and 'tissue disposition'.

Current views of morphogenesis in plants employ new terminology to describe the events that occur in the activation of pre-positioned primordia and the initiation of de novo 
centers of regeneration. Recent advances in understanding cell-to-cell communication and control of differentiation at the biochemical, molecular and physical levels of organization have led to the synthesis of developmental ideas that, when applied to regeneration, necessitate a regrouping of these phenomena under the broader heading of developmental theory. Steeves and Sussex $(1989, \mathrm{pg} .336)$ remark that it is important to recognize that, in de novo regeneration it is not an organized root, shoot or flower that is being initiated but rather a meristem. This meristem may not be determined until sometime after its initiation and prior to its gaining autonomous control over its developmental fate. Thus, the entire realm of adventitious development can be seen as the study of pre-formed (and in some cases, still indeterminate) meristematic centers or primordia, or the study of, what appears to be, the de novo formation of meristematic zones (Anlagen?). In each case, the cells or tissues involved may be seen as being at the center of a morphogenic field, with the meristem being a morphogenic unit and its activities establishing the boundaries of a larger field of developmental influence.

The ideas discussed above were originally written to serve as an introduction to a study of de novo meristem formation with particular emphasis on the role of the epidermis as a potent generative and formative tissue system. Interest in this area is founded on a desire to understand plants in terms of organismal theory. A return to this work is anticipated in the future. 


\section{Literature Cited}

Arditti, J. (1982). Orchid seed germination and seedling culture - a manual. In J. Arditti (ed), Orchid Biology - Reviews and Perspectives II. Ithaca, New York. Comstock Publishing Associates, Cornell University Press.

Dore, J. (1955). Studies in the regeneration of horseradish. 1. A re-examination of the morphology and anatomy of regeneration. Annals of Botany, 19, 127-137.

Eames, A. J. and Mac Daniels, L.H. (1947). An Introduction to Plant Anatomy. New York. McGraw-Hill Book Company, Inc.

Esau, K. (1967). Plant Anatomy ( $2^{\text {nd }}$ ed.). New York. John Wiley and Sons, Inc. Pg.513

Fahn, A. (1974). Plant Anatomy ( $2^{\text {nd }}$ ed.). Oxford, UK. Pergamon Press.

Goebel, K. (1903). Regeneration in plants. Bulletin of the Torrey Botanical Club, 3(4), 197-205.

Gray, A. (1887). The Elements of Botany for Beginners and Schools (revised ed.). Boston. American Book Company.

Harrison, L. G. (1992). Reaction diffusion theory and intracellular differentiation. International Journal of Plant Science, 153, S76-S85.

Raven, P.H., Evert, R.F., \& Eichhorn, S.E. (1992). Biology of Plants (2 $2^{\text {nd }}$ ed.). New York, Worth Publishers. Pg. 449

Sinnot. W. E. (1960). Plant Morphogenesis. New York. McGraw Hill Book Company.

Steeves, T.A. \& Sussex, I.M. (1989). Patterns in Plant Development. New York, New York. Cambridge University Press. 


\section{Bibliography}

Adamec, L. (2002). Leaf absorption of mineral nutrients in carnivorous plants stimulates root nutrient uptake. New Phytologist, 155, 89-100.

Adamec, L. (1997). Mineral nutrition of carnivorous plants: A review. The Botanical Review, 63, 273-299.

Adams II, R.M., Koenigsberg, S.S., \& Langhans, R.W. (1979a). In vitro propagation of Cephalotus follicularis (Australian pitcher plant). HortScience, 14, 512-513.

Adams II, R.M., Koenigsberg, S.S., \& Langhans, R.W. (1979b). In vitro propagation of the butterwort Pinguicula moranensis h.b.k. HortScience, 14, 701-702.

Albert, V.A., Williams, S.E., \& Chase, M.W. (1992). Carnivorous plants: phylogeny and structural evolution. Science, 257, 1491-1495.

Amen, R.D. (1967). The effects of gibberellic acid and scarification on the seed dormancy and germination in Luzula spicata. Physiologia Plantarum, 20, 6-12.

Ames, O. (1899). An easy method of propagating Drosera filiformis. $\underline{\text { Rhodora, } 1,172 .}$

Anthony, L.J. (1992). In vitro propagation of Drosera spp. HortScience, 27, 850.

Arditti, J. (1982). Orchid seed germination and seedling culture - a manual. In J. Arditti (ed), Orchid Biology - Reviews and Perspectives II. Ithaca, New York. Comstock Publishing Associates, Cornell University Press.

Ball, E. (1956). Growth of the embryo of Ginkgo biloba under experimental conditions. I. Origin of the first root of the seedling in vitro. American Journal of Botany, 43, 488-495.

Ball, E. (1956). Growth of the embryo of Ginkgo biloba under experimental conditions. II. Effects of a longitudinal split in the tip of the hypocotyl. American Journal of Botany, 43, 802-810. 
Ball, E. (1959). Growth of the embryo of Ginkgo biloba under experimental conditions. III. Growth rates of root and shoot upon media absorbed through the cotyledons. American Journal of Botany, 46 (2), 130-139.

Barrett-Lennard, E.G. \& Dracup, M. (1988). A porous agar medium for improving the growth of plants under sterile conditions. Plant and Soil, 108, 294-298.

Barton, L.V. (1965). Viability of seeds of Theobroma cacao l. Contributions from Boyce Thompson Institute, 23, 109-122.

Baskin, C.C. \& Baskin, J.M. (1998). Seeds; ecology, biogeography, and evolution of dormancy and germination. San Diego, CA. Academic Press.

Beebe, J.D. (1980). Morphogenetic responses of seedlings and adventitious buds of the carnivorous plant Dionaea muscipula in aseptic culture. Botanical Gazette, 141, 396-400.

Beeckman, T., De Rycke, R., Viane, R., \& Inze, D. (2000). Histological study of seed coat development in Arabidopsis thaliana. Journal of Plant Research, 113, 139148.

Bewley, J.D. \& Black, M. (1994). Seeds - Physiology, Development and Germination $\left(2^{\text {nd }}\right.$ ed.). New York, London. Plenum Press.

Bhojwani, S.S. \& Johri, B.M. (1971). Morphogenetic studies on cultured mature endosperm of Croton bonplandianum. New Phytologist 76, 761-766.

Blehova, A., Erdelsky, K., \& Bobak, M. (1992). Cultivation of organ and callus culture of Drosera spathulata Labill. in in vitro conditions. Physiologia Plantarum 27, 93-101.

Bobak, M., Blehova, A., \& Erdelsky, K. (1989). Histological and cytological study of early phases of organogenesis on excised leaves of Drosera spathulata L. cultivated in vitro. Biologia, 44, 795-792. 
Bobak, M., Blehova, A., Cholvadova, B., \& Somsakova, V. (1990). Morphogenesis of the plastid apparatus in the process of organogenesis at the leaves of the sundew (Drosera spathulata L.), cultivated in in vitro conditions. Physiologia Plantarum. $\underline{25}, 33-41$.

Bobak, M., Blehova, A., Kristin, J., Ovecka, M., \& Samaj, J. (1995). Direct plant regeneration from leaf explants of Drosera rotundifolia cultured in vitro. Plant Cell, Tissue and Organ Culture, 43, 43-49.

Bobak, M., Blehova, A., Samaj, J., \& Ovecka, M. (1993). Studies of organogenesis from the callus culture of the sundew (Drosera spathulata Labill.). Plant Physiology, $\underline{142}, 251-253$.

Bobak, M., Samaj, J., Blehova, A., Ovecka, M., Novomeska, S., \& Kristin, J. (1998). Morphology and ultrastructure of isolated gemmae of Drosera pygmaea and their in vitro germination. Biologia Plantarum, 41, 169-176.

Boulay, J. (1995). Les plantes carnivores, essais de micropropagation. Bulletin des Academie et Societe Lorraines des Sciences, 34, 151-159.

Brigham, L.A., Michaels, P.J., \& Flores, H.E. (1999). Cell-specific production and antimicrobial activity of naphthoquinones in roots of Lithospermum erithrorhizon. Plant Physiology, 119, 417-428.

Budzianowski, J. (2000). Naphthoquinone glucosides of Drosera gigantea from in vitro cultures. Planta Medica, 66, 667-669.

Budzianowski, J. (1997). 2-methylnaphthazarin 5-O-glucoside from the methanol extracts of in vitro cultures of Drosera species. Phytochemistry, 44, 75-77.

Budzianowski, J. (1996). Naphthohydroquinone glucosides of Drosera rotundifolia and D. intermedia from in vitro cultures. Phytochemistry, 4, 1145-1147.

Budzianowski, J. (1995). Naphthoquinones of Drosera spathulata from in vitro cultures. Phytochemistry, 40, 1145-1148. 
Burgher, R.M.(1961). Axenic seedlings of Drosera. Nature, 191, 724-725.

Busse, J.S. \& Evert, R.F. (1999). Pattern of differentiation of the first vascular elements in the embryo and seedling of Arabidopsis thaliana. International Journal of Plant Science, 160, 1-13.

Carroll, G. (1988). Fungal endophytes in stems and leaves: From latent pathogen to mutualistic symbiont. Ecology, 69, 2-9.

Chandler, G.E. \& Anderson, J.W. (1967). Studies on the origin of some hydrolytic enzymes associated with the leaves and tentacles of Drosera species and their role in heterotrophic nutrition. New Phytologist, 77, 51-62.

Cheers, G. (1992). A Guide to Carnivorous Plants of the World. New York. Angus \& Robertson, Harper Collins Publishers.

Chen, L., James, S.H., \& Stace, H.M. (1997). Self-incompatibility, seed abortion and clonality in the breeding systems of several western Australian Drosera species (Droseraceae). Australian Journal of Botany, 45, 191-201.

Clay, K. (1988). Fungal endophytes of grasses: a defensive mutualism between plants and fungi. Ecology, 69, 10-16.

Clay, K (1989). Clavicipitaceous endophytes of grasses: their potential as biocontrol agents. Mycological Research, 92, 1-12.

Conran, J.G. \& Dowd, J.M. (1993). The phylogenetic relationships of Byblis and Roridula (Byblidaceae-Roridulaceae) inferred from partial 18S ribosomal RNA sequences. Plant Systematics and Evolution, 188, 73-86.

Crouch, I.J., Finnie, J.F., \& van Staden. J. (1990.) Studies on the isolation of plumbagin from in vitro and in vivo grown Drosera species. Plant Cell, Tissue and Organ Culture, 21, 79-82. 
Crouch, I.J. \& van Staden, J. (1987). In vitro propogation of Drosera natalensis. $\underline{\text { South }}$ African Journal of Botany, 54, 94-95.

D'Amato, P. (1998). The Savage Garden. Berkeley, California. Ten Speed Press.

Darwin, C. (1875). Insectivorous Plants. London. John Murray.

Das, S., Mitra, S.K., \& Mukherjee, K.K. (1995). SEM studies on seed coat of some species of Ipomoea (Convolvulaceae). Phytomorphology, 45, 113-125.

Dodds, J.H. \& Roberts, L.W. (1995). Experiments in Plant Tissue Culture $\left(3^{\text {rd }}\right.$ ed.). Cambridge. Cambridge University Press.

Dore, J. (1955). Studies in the regeneration of horseradish. 1. A re-examination of the morphology and anatomy of regeneration. Annals of Botany, 19, 127-137.

Dore, J. \& Williams, W.T. (1956). Studies in the regeneration of horseradish. 2. Correlation phenomena. Annals of Botany, 20, 231-249.

Dore, J., Swamy, R., \& Mohan Ram, H.Y. (1969). Studies on growth and flowering in axenic cultures of insectivorous plants. I. Seed germination and establishment of Utricularia inflexa. Phytomorphology, 19, 363-371.

Dore, J., Swamy, R., \& Mohan Ram, H.Y. (1971). Studies on the growth and flowering in axenic cultures of insectivorous plants. II. Induction of flowering and development of flower in Utricularia inflexa. Zeitschrift fur Pflanzenphysiologie, 65, 315-325.

Eames, A. J. and Mac Daniels, L.H. (1947). An Introduction to Plant Anatomy. New York. McGraw-Hill Book Company, Inc.

Esau, K. (1967). Plant Anatomy ( $2^{\text {nd }}$ ed.). New York. John Wiley and Sons, Inc. Pg. 513. 
Ellison, A.M. (2001). Interspecific and intraspecific variation in seed size and germination requirements of Sarracenia (Sarraciniaceae). American Journal of Botany, 88, 429-437.

Ellison, A.M. and Gotelli, N.J. (2001). Evolutionary ecology of carnivorous plants. Trends in Ecology and Evolution, 6, 623-629.

Ellison, A.M. and Parker, J.N. (2002). Seed dispersal and seedling establishment of Sarracenia purpurea (Sarraceniaceae). American Journal of Botany, 89, 10241026.

Fahn, A. (1974). Plant Anatomy ( $2^{\text {nd }}$ ed.). Oxford, UK. Pergamon Press.

Franck, D.H. (1975). Early histogenesis of the adult leaves of Darlingtonia californica (Sarraceniaceae) and its bearing on the nature of epiascidiate foliar appendages. American Journal of Botany, 62, 116-132.

Franck, D.H. (1976). Comparative morphology and early leaf histogenesis of adult and juvenile leaves of Darlingtonia californica and their bearing on the concept of heterophylly. Botanical Gazette, 137, 20-34.

Francko, D.A. (1986). Studies on Nelumbo lutea (Wild.) pers. I. Techniques for axenic liquid seed culture. Aquatic Botany, 26, 113-117.

Gallardo, K., Job, C., Groot, S.P.C., Puype, M., Demol, H., Vandekerckhove, J., \& Job, D. (2001). Proteomic analysis of Arabidopsis seed germination and priming. Plant Physiology, 126, 835-848.

George, E.F. \& Sherrington, P.D. (1984). Plant Propagation by Tissue Culture. Edington, UK. Exergetics Limited.

Givnish, T.J. (1989). Ecology and evolution of carnivorous plants. In W. G. Abrahamson. Plant-Animal Interactions. (pp. 243-290). New York. McGraw-Hill Inc. 
Godt, M.J.W. \& Hamrick, J.L. (1996). Genetic structure of two endangered pitcher plants, Sarracenia jonseii and S. oreophila (Sarraceniaceae). American Journal of Botany, 83, 1016-1023.

Godt, M.J.W \& Hamrick, J.L. (1998). Allozyme diversity in the endangered pitcher plant Sarracenia rubra ssp. alabamensis (Sarraceniaceae) and its close relative $S$. rubra ssp. rubra. American Journal of Botany, 85, 802-810.

Goebel, K. (1903). Regeneration in plants. Bulletin of the Torrey Botanical Club, 3(4), 197-205.

Gotsch, S.G. \& Ellison, A.M. (1998). Seed germination of the northern pitcher plant, Sarracenia purpurea. Northeastern Naturalist, $5,175-182$.

Gray. A. (1887). The Elements of Botany for Beginners and Schools (revised ed.). Boston. American Book Company.

Harder, R. (1964). Vegetative entwicklung und blutenbildung in axenischen kulturen der insektivore Drosera pygmaea Dc. Planta, 63, 316-325.

Harder, R. \& Zemlin, I. (1967). Forderung der entwicklung und des bluhens von Pinguicula lusitanica durch futterung in axenischer kultur. Planta (Berl.), 73, 181193.

Harrison. L. G. (1992). Reaction diffusion theory and intracellular differentiation. International Journal of Plant Science, 153, S76-S85.

Hartman, H.T. \& Kester, D.E. (1975). Plant Propagation: Principles and Practices $\left(3^{\text {rd }}\right.$ ed.). Englewood Cliffs, New Jersey. Prentice Hall.

Hartman, H.T., Kester, D.E., Davies, Jr., F.T., \& Geneve, R.L. (1997). Plant Propagation: Principles and Practice $\left(6^{\text {th }}\right.$ ed.). Englewood Cliffs, New Jersey. Prentice Hall.

Hinton, D.M. \& Bacon, C.W. (1984). The distribution and ultrastructure of the endophyte of toxic tall fescue. Canadian Journal of Botany, 63, 36-42. 
Hook, I.L.I. (2001). Naphthoquinone contents of in vitro cultured plants and cell suspensions of Dionaea muscipula and Drosera species. Plant Cell, Tissue and Organ Culture, 67, 281-285.

Hu, C.Y. \& Wang, P.J. (1983). Meristem, shoot tip and bud cultures. In D.A. Evans, W.R. Sharp, P.V. Ammirato and Y. Yasuyuki. Handbook of Plant Cell Culture. New York. Macmillan Publishing Co. Pgs. 177-227.

Jasik, J., Salajova, T., \& Salaj, J. (1995). Developmental anatomy and ultrastructure in European black pine (Pinus nigra Arn.). Protoplasma, 185, 205-211.

Jaffe, K., Michelangeli, F., Gonzalez, J.M., Miras, B., \& Ruiz, M.C. (1992). Carnivory in pitcher plants of the genus Heliamphora (Sarraciniaceae). New Phytologist, 122, 733-744.

Kane, M.E., Sheehan, T.J., \& Ferwerda, F.H. (1988). In vitro growth of American lotus embryos. HortScience, 23, 611-613.

Knudson, L. (1946). A nutrient solution for the germination of orchid seed. American Orchid Society Bulletin, 14, 214-217.

Kohlenbeck, H.W. (1978). Comparative Somatic Morphogenesis. In T. A. Thorpe. Frontiers of Plant Tissue Culture. Bet Dagan, Israel. International Association for Plant Tissue Culture.

Koske, R.E. (1977). Spiral growth of Phycomyces: some new observations in the Northern and Southern hemispheres. Mycologia, 69, 189-193.

Lackie, S. \& Yeung, E.C. (1995). Zygotic embryo development in Daucus carota. Canadian Journal of Botany, 74, 990-998.

Lane, W.D. (1979). The influence of growth regulators on root and shoot initiation from flax meristem tips and hypocotyls in vitro. Physiologia Plantarum, 45, 260-264. 
Lecoufle, M. (1990). Carnivorous Plants: Care and Cultivation. London, England. Cassell Publishers Ltd.

Liddell, R. (1953). Germination of Paphiopediulum. American Orchid Society Bulletin 22:195

Leifert, C. \& Waites, W.M. (1992). Bacterial growth in plant tissue culture media. Journal of Applied Bacteriology, 72, 460-466.

Leifert, C., Waites, W.M., Camotta, H., \& Nicholas, J.R. (1989). Lactobacillus plantarum: a deleterious contaminant of plant tissue cultures. Journal of Applied Bacteriology, 67, 363-370.

Leifert, C., Waites, W.M., \& Nicholas, J.R. (1989). Bacterial contaminants of micropropagated plant cultures. Journal of Applied Bacteriology, 67, 353-361.

Leifert, C., Waites, W.M., Nicholas, J.R. \& Keetley, J.W.W. (1990). Yeast contaminants of micropropagated plant cultures. Journal of Applied Bacteriology, 69, 471-476.

Levitt, R.G. (1903). Reversionary stages experimentally induced in Drosera intermedia. Rhodora, 5, 265-272.

Li, X., Baskin, J.M., \& Baskin, C.C. (1999). Comparative morphology and physiology of fruit and seed development in the two shrubs Rhus aromatica and $R$. glabra (Anacardiaceae). American Journal of Botany, 86, 1217-1225.

Lichtscheidl, I.K., Lancelle, S.A., \& Hepler, P.K. (1990). Actin-endoplasmic reticulum complexes in Drosera. Protoplasma, 155, 116-126.

Linsmaier, E. \& Skoog, F. (1965). Organic growth factor requirements of tobacco tissue cultures. Physiologia Plantarum, 185, 100-127.

Lloyd, E.F. (1942). The Carnivorous Plants. Waltham, Massachusetts. Chronica Botanica Co. 
Lyshede, O.B. (1984). Seed structure and germination in Cuscuta pedicellata with some notes on C. campestris. Nordic Journal of Botany, 4, 669-67.

Lyshede, O.B. (1992). Studies on mature seeds of Cuscuta pedicellata and C. campestris by electron microscopy. Annals of Botany, 69, 365-371.

MacDougal, D.T. (1903). The influence of light and darkness upon growth and development. Memoirs of the New York Botanical Garden, 2, 1-319.

Malgorzata, D.G. (2001). Direct somatic embryogenesis as a rapid and efficient system for in vitro regeneration of Arabidopsis thaliana. Plant Cell, Tissue and Organ Culture, 64, 39-46.

Malik, K.A. \& Saxena, P.K. (1991). Regeneration in Phaseolus vulgaris L.: High frequency induction of direct shoot formation in intact seedlings by $\mathrm{N}^{6}-$ benzylaminopurine and thidiazuron. Planta, 186, 384-389.

Mandossian, A.J. (1966). Germination of seeds in Sarracenia purpurea (pitcher plant). Michigan Botanist, 5, 67-69.

Martin, A.C. (1946). The comparative internal morphology of seeds. The American Midland Naturalist, 36, 513-589.

Mayer, A.M. \& Poljakoff-Mayber, A. (1982). The Germination of Seeds. $\left(3^{\text {rd }}\right.$ ed.). Oxford, UK. Pergamon Press.

McCarty, D.R. (1995). Genetic control and integration of maturation of germination pathways in seed development. Annual Review of Plant Physiology and Plant Molecular Biology, 45, 71-93.

Miles, D.H., Kokpol, U., Zalkow, L.H., Steindel, S.J., \& Nabors, J.B. (1974). Preliminary investigation of antitumor activity of Sarracenia flava. Journal of Pharmaceutical Science, 63,613 .

Minocha, S.C. (1985.) In vitro propagation of Dioncea muscipula. HortScience, 20, 216217. 
Morel, G. (1974). Clonal Multiplication of Orchids. In: The Orchids, Scientific Studies. Withner, C.L. (Ed) Wiley-Interscience, New York, Pgs. 169-222.

Munday, R. \& Munday, C.M. (2000). Induction of quinone reductase and glutathione transferase in rat tissues by juglone and plumbagin. Planta Medica, 66, 399-402.

Murashige, T. \& Skoog, F. (1962). A revised medium for rapid growth and bioassays with tobacco tissue culture. Physiologia Plantarum 15, 473-497.

Parliman, B.J., Evans, P.T., \& Mazur, A.R. (1982). Adventitious bud differentiation and development in leaf cuttings of Dionaea muscipula Ellis ex. L. (venus fly trap) cultured in vitro. Journal of the American Society of Horticultural Science, 107, 310-316.

Parliman, B.J., Evans, P.T., \& Rupert, E.A. (1982). Tissue culture of single rhizome explants of Dionaea muscipula Ellis ex. 1., the venus fly trap, for rapid asexual propagation. Journal of the American Society of Horticultural Science, 107, 305310.

Pate, J.S. \& Dixon, K.W. (1978). Phenology and reproductive biology of the tuberous sundew, Drosera erythrorhiza Lindl. Australian Journal of Botany, 26, 441-454.

Perica, M.C \& Berljak, J. (1996). In vitro growth and regeneration of Drosera spathulata Labill. on various media. HortScience, 31, 1033-1034.

Pietropaolo, J. \& Pietropaolo, P. (1986). Carnivorous Plants of the World. Portland, Oregon. Timber Press.

Poole, R.J. (1941). Flowers and Flowering Plants $\left(2^{\text {nd }}\right.$ ed.). New York, McGraw Hill Book Co. Inc.

Popham, R.A. (1959). Effects of a low temperature on germination of cotton seeds and on growth of the embryo. The Texas Journal of Science, 11, 299-313.

Pringsheim, E.G. \& Pringsheim, O. (1962). Axenic culture of Utricularia. American Journal of Botany, 49, 898-901. 
Rasmussen, H.N. \& Whigham, D.F. (1998). Importance of woody debris in seed germination of Tipularia discolor (Orchidaceae). American Journal of Botany, 85, 829-834.

Rathore, T.S., Tandon, P. \& Shekhawat, N.S. (1991). In vitro regeneration of pitcher plant (Nepenthes khasiana Hook. f.) - a rare insectivorous plant of India. Journal of Plant Physiology, 139, 246-248.

Raven, P.H., Evert, R.F., \& Eichhorn, S.E. (1992). Biology of Plants $\left(2^{\text {nd }}\right.$ ed.). New York, Worth Publishers. Pg. 449.

Redwood, G. \& Bowling, D. (1990). Micropropagation of Nepenthes species. Botanic Gardens Micropropagation News, 1, 19-20.

Reeves, R.D., Macfarlane, R.M., \& Brooks, R.R. (1983). Accumulation of nickel and zinc by western North American genera containing serpentine-tolerant species. American Journal of Botany, 70, 1297-1303.

Reiser, L., Sanchez-Baracaldo, P., \& Hake, S. (2000). Knots in the family tree: evolutionary relationships and functions of knox homeobox genes. Plant Molecular Biology, 42, 51-166.

Remeshree, A.B., Hariharan, M., \& Unnikrishnan, K. (1994). Micropropagation and callus induction of Aristolochia bracteolata Lam. - a medicinal plant. Phytomorphology, 44, 247-252.

Samaj, J., Bobak, M., Blehova, A., Kristin, J., \& Auxtova-Samajova, O. (1995). Developmental SEM observations on an extracellular matrix in embryogenic calli of Drosera rotundifolia and Zea mays. Protoplasma, 186, 45-49.

Sarma, K.S., Maesato, K., Hara, T., \& Sonoda, Y. (1990). Effect of method of agar addition on post-autoclave $\mathrm{pH}$ of the tissue culture media. Annals of Botany, 65, $37-40$. 
Schnell, D.E. (2002). Carnivorous Plants of the United States and Canada ( $2^{\text {nd }}$ ed.). Portland, Oregon. Timber Press.

Schwarz, O.J., \& Beaty, R.M. (1996). In R. N. Trigiano \& D. J. Gray. Plant Tissue Culture Concepts and LaboratoryExercises. Boca Raton, Florida. CRC Press, lnc.

Sharpe, W.R., Sondahl, M.R., Caldas, L.S., \& Maraffa, S.B. (1980). The physiology of in vitro asexual embryogenesis. Horticultural Reviews, 2, 268-310.

Shreve, F. (1906). The development and anatomy of Sarracenia purpurea. Botanical Gazette, 42, 107-126.

Simola, L.K. (1978). Dipeptides as nitrogen sources for Drosera rotundifolia in aseptic culture. Physiologia Plantarum, 44, 315-318.

Sinnot, W. E. (1960). Plant Morphogenesis. New York. McGraw Hill Book Company.

Slack, A. (2000). Carnivorous Plants ( $3^{\text {rd }}$ impression). Cambridge, Massachusetts. The MIT Press.

Smith, C.M. (1929). Development of Dionaea muscipula 1. Flower and seed. Botanical Gazette, 87, 507-530.

Smith, C.M. (1931). Development of Dionaea muscipula II. Germination of seed and development of seed to maturity. Botanical Gazette, 91, 377-394.

Steeves, T.A. \& Sussex, I.M. (1989). Patterns in Plant Development. New York, New York. Cambridge University Press.

Steyermark, J.A. (1984). Flora of the Venezuelan guayana I. Annals of the Missouri Botanical Garden, 71, 297-340.

Sutter, E. \& Langhans, R.W. (1979). Epicuticular wax formation on carnation plantlets regenerated from shoot tip culture. Journal of American Horticultural Science, $104,493-496$. 
Sweet, H.C. \& Bolton, W.E. (1979). The surface decontamination of seeds to produce axenic seedlings. American Journal of Botany, 66, 692-698.

Teo, W.L., Kumar, P., Goh, C., \& Swarup, S. (2001). The expression of Brostm, a KNOTTED1-like gene, marks the cell type and timing of in vitro shoot induction in Brassica oleracea. Plant Molecular Biology, 46, 567-580.

Thorpe, T.A. \& Palel, K.R. (1984). Clonal Propagation: Adventitious Buds. In I.K. Vasil (ed.). Cell Culture and Somatic Cell Genetics of Plants (vol. I). Oxford, United Kingdom. Academic Press Inc. Pgs. 49-60

Thurston, K.C., Spencer, S.J., \& Arditti, J. (1979). Phytotoxicity of fungicides and bactericides in orchid culture media. American Journal of Botany, 66 (7), 825835.

Toogood, A. (1999). Plant Propagation. New York, New York. DK Publishing, Inc.

Tran Thanh Van, K. \& Trinh, H. (1978). Morphogenesis in Thin Cell Layers: Concept, Methodology and Results. In T. A. Thorpe (ed.). Frontiers of Plant Tissue Culture. International Association for Plant Cell Culture.

Truscott, F.H. (1966). Some aspect of morphogenesis in Cuscuta gronovii. American Journal of Botany, 53, 739-750.

Tulecke, W. \& McGranahan. (1985). Somatic embryogenesis and plant regeneration from cotyledons of walnut, Juglans regial. Plant Science, 40, 57-63.

Vacin, E. \& Went, F.W. (1949). Some pH changes in nutrient solutions. Botanical Gazette, 110, 605-613. 
Verbeke, J.A. \& Walker, D.B. (1986). Morphogenic factors controlling differentiation and dedifferentiation of epidermal cells in the gynoecium of Catharanthus roseus. II. Diffusible morphogens. Planta, 168, 43-49.

Vickery, J.W. (1933). Vegetative reproduction in Drosera peltata and D. auriculata. Proceedings of the Linnaen Society New South Wales, 58, 245-269.

Vidaver, W. (1977). Light and seed germination. In A.A. Khan (ed.). The Physiology and Biochemistry of Seed Dormancy and Germination. Amsterdam, The Nethertlands. North Holland Publishing Company.

Wallace, H.A.H. (1960). Factors affecting subsequent germination of cereal seeds sown in soils of subgermination moisture content. Canadian Journal of Botany, 38, 287306.

Walker, D.B. (1975). Postgenital carpel fusion in Catharanthus roseus (Apocynaceae). I. Light and scanning electron microscopic study of gynoecial ontogeny. American Journal of Botany, 62, 457-467.

Walker, D.B. (1978). Morphogenic factors controlling differentiation and dedifferentiation of epidermal cells in the gynoecium of Catharanthus roseus. I. The role of pressure and cell confinement. Planta, 142, 181-186.

Wardlaw, C.W. (1968). Morphogenesis in Plants: A Contemporary Study. London, England. Methuen \& Co., Ltd.

Weber, H., Heim, U., Golombek, S., Borisjuk, L., \& Wobus, U. (1998). Assimilate uptake and the regulation of seed development. Seed Science Research, 8, 331345.

Wetherell, D.F. \& Halperin. W. (1963). Embryos derived from the callus tissue cultures of the wild carrot. Nature, 200, 336-1337.

White, J.F. Jr., Anthony, G.E., \& Chandler, K.F. (1993). Endophyte-host associations in grasses. XVIII. Moisture relations and insect herbivory of the emergent stromal leaf of Epichloe. Mycologia, 85, 195-202. 
White Jr., J.F. \& Chambless, D.A. (1991). Endophyte-host associations in forage grasses. XV. Clustering of stomata-bearing individuals of Agrostis hiemalis infected by Epichloe typhnia. American Journal of Botany, 78, 527-533.

White, J.F. Jr. \& Cole, G.T. (1986). Endophyte-host associations in forage grasses. IV. The endophyte of Festuca versuta. Mycologia, 78, 02-107.

White, J.F. Jr., Morrow, A.C., Morgan-Jones, G., \& Chambless, D.A. (1991). Endophytehost associations in forage grasses. XIV. Primary stomata formations and seed transmission in Epichloe typhina: developmental and regulatory aspects. Mycologia, 83, 72-81.

Withner, C.L. (1964). Notes on the cultivation of insectivorous plants in vitro. Bulletin of the Torrey Botanical Club, 91, 412-413.

Zenk, M.H., Furbringer, M., \& Steglich, W. (1969). Occurrence and distribution of 7methyljuglone and plumbagin in the Droseraeceae. Phytochemistry, 8, 21992200.

Ziv, M (1979) Transplanting Gladiolus plants propagated in vitro. Scientia Horticulturae, 11, 257- 260 . 